Filipe Galiforni Silva

\title{
Dinâmica morfo-sedimentar ao longo do sistema praial da Ilha Comprida - SP
}

\author{
Dissertação apresentada ao Instituto \\ Oceanográfico da Universidade de São \\ Paulo, como parte dos requisitos para \\ obtenção do título de Mestre em Ciências, \\ Programa de Oceanografia, área de \\ Oceanografia Geológica.
}

Orientador: Prof. Dr. Eduardo Siegle

São Paulo 
Universidade de São Paulo

Instituto Oceanográfico

Dinâmica morfo-sedimentar ao longo do sistema praial da Ilha Comprida - SP

(Versão corrigida)

Filipe Galiforni Silva

Dissertação apresentada ao Instituto Oceanográfico da Universidade de São Paulo, como parte dos requisitos para obtenção do título de Mestre em Ciências, Programa de Oceanografia, área de Oceanografia Geológica

Julgada em

Conceito

Prof. Dr. Eduardo Siegle

Conceito

$\operatorname{Prof}(\mathrm{a}) . \operatorname{Dr}(\mathrm{a})$.

Conceito

$\operatorname{Prof}(\mathrm{a}) . \operatorname{Dr}(\mathrm{a})$.

Conceito 


\section{SUMÁRIO}

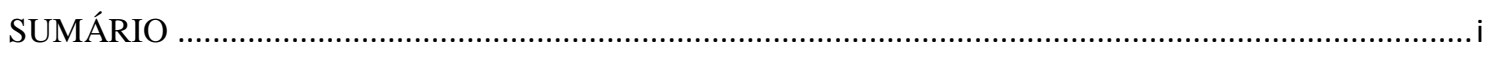

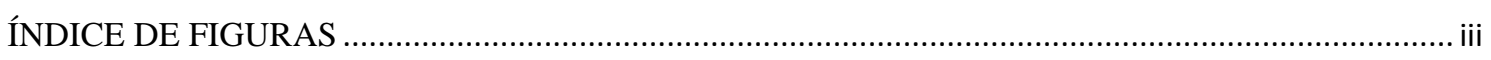

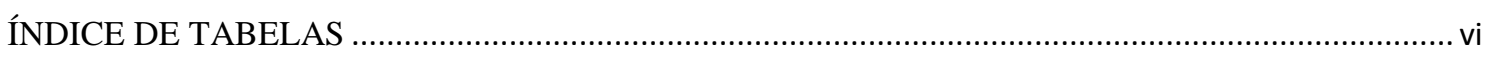

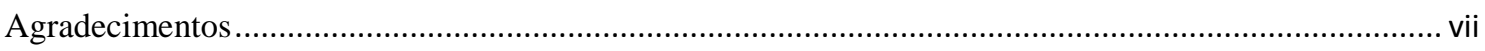

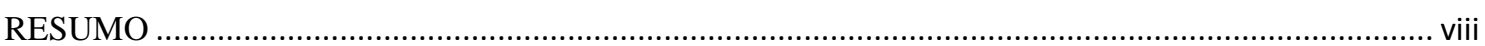

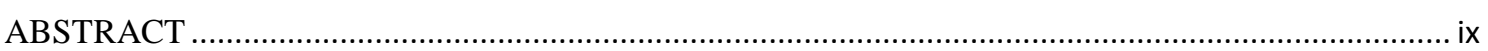

1 INTRODUÇÃ

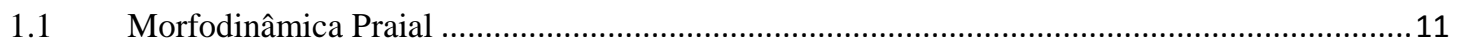

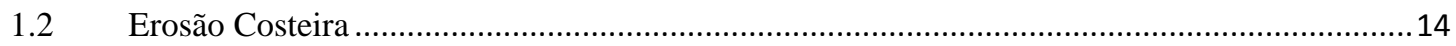

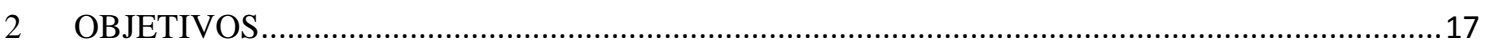

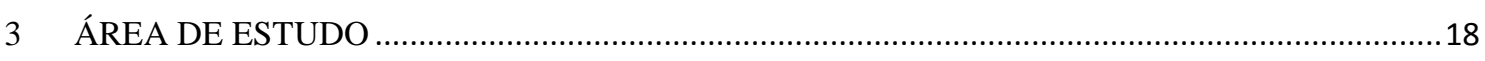

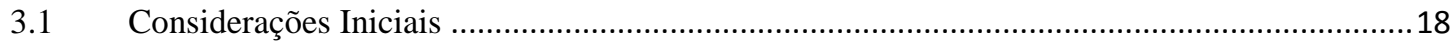

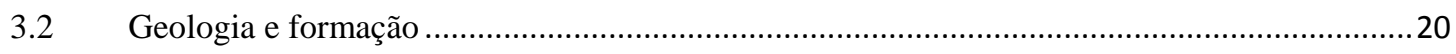

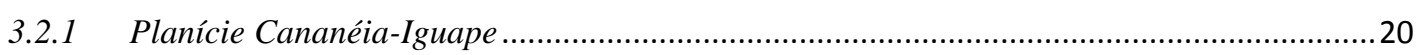

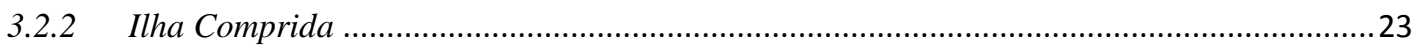

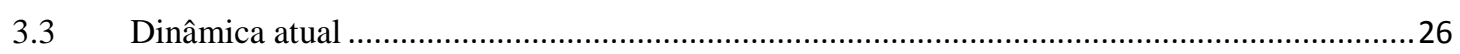

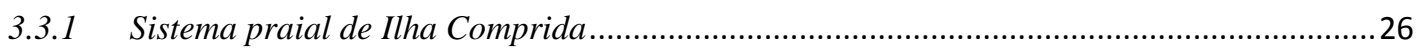

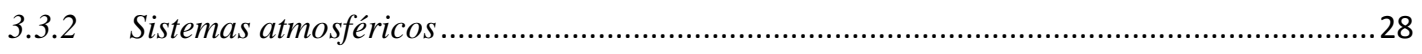

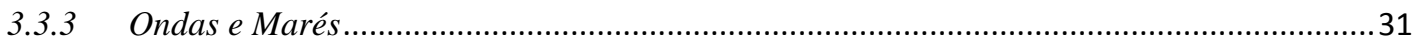

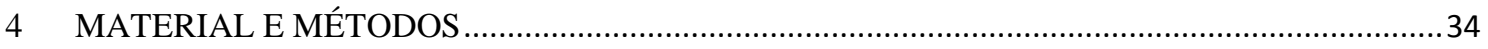

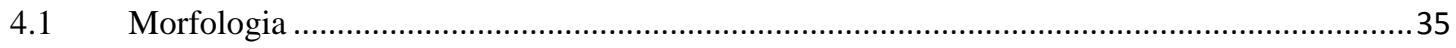

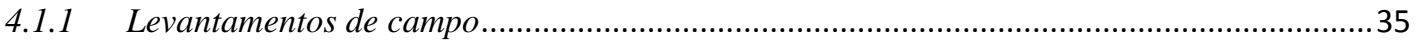

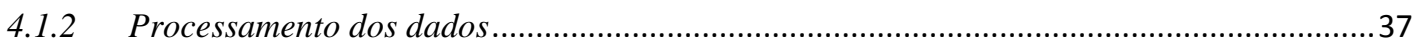

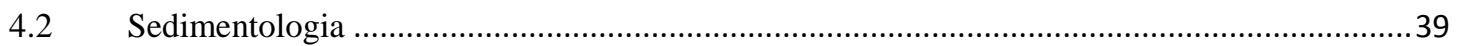

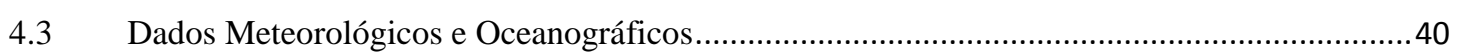

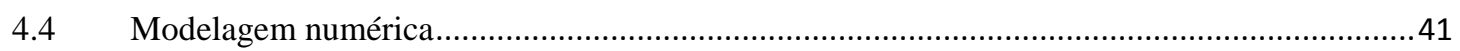

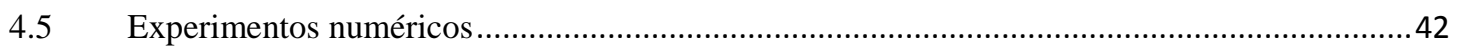

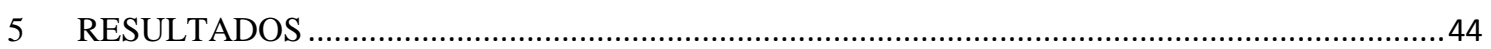

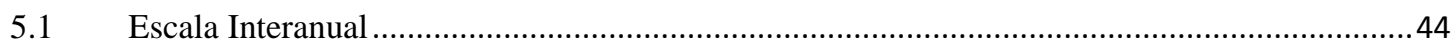

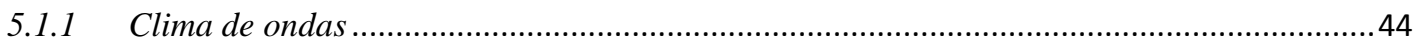

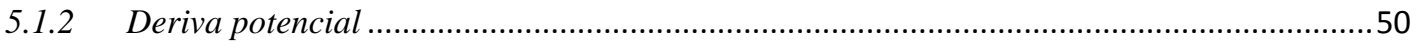

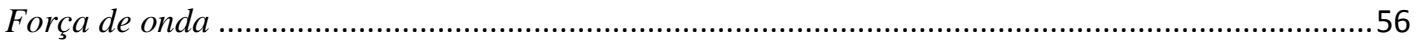

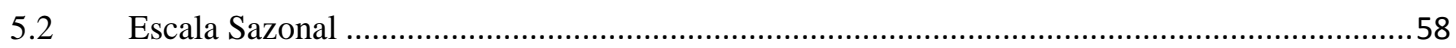


5.2.1 Condições atmosféricas e oceanográficas.....................................................................58

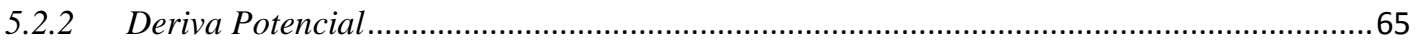

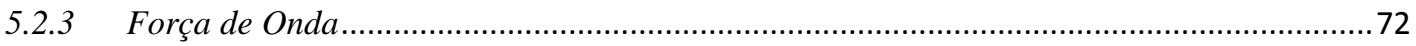

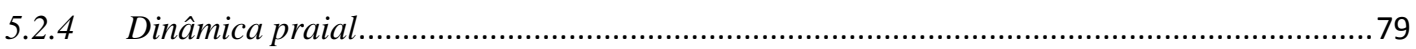

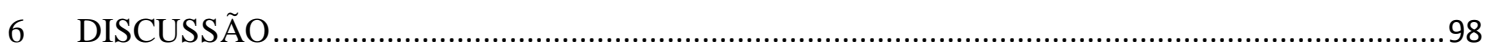

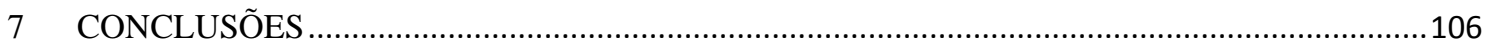

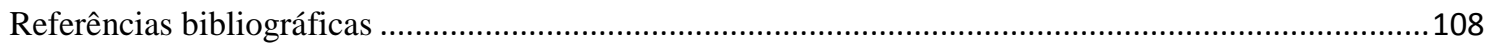

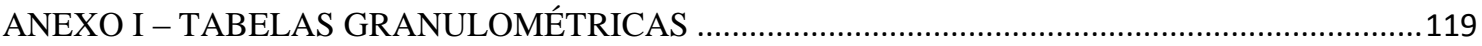

ANEXO II - MAPAS DE VARIAÇÃO ALTIMÉTRICA ............................................................... 125 


\section{ÍNDICE DE FIGURAS}

Figura 1.1: Terminologia Dos Setores De Uma Praia. Adaptado De Goya \& Tessler (2000) ...................12

Figura 3.1: Localização espacial da área de estudo. .............................................................................20

Figura 3.2: Mapa geológico da região, evidenciando os sedimentos que compõe a planície CananéiaIguape, bem como as principais falhas e afloramentos (adaptado de Guedes et.al., 2011).......................22 Figura 3.3: Modelo evolutivo para a ilha proposto por Guedes et. al. (2011), com cinco estágios de crescimento relacionados com variações do nível do mar relativo ao quaternário. A: Primeira fase (6000 AP); B: Segunda fase (5000AP); C: Terceira fase (1900 AP), D: Quarta fase (200 AP); E: Quinta fase (Presente)

Figura 4.1: Localização aproximada dos cinco setores de levantamentos de campo (círculos vermelhos), bem como a subdivisão adotada para análise das propriedades hidrodinâmicas. ....................................35 Figura 4.2: Aparelho GPS de precisão utilizado como base móvel, calibrando sua posição para o início do levantamento (esquerda). Exemplo fotográfico do método adotado para o caminhamento (direita). ........36 Figura 4.3: Exemplo de distribuição espacial dos transectos longitudinais e transversais de coleta de dados altimétricos, com o uso do DGPS, evidenciando a tentativa distribuição regular da malha. Malha utilizada como exemplo, antes da limitação horizontal. Escala em metros e representação em UTM. ...................37

Figura 4.4: Cálculo da altura ortométrica e esboço do elipsoide e geoide. Fonte: IBGE ..........................38

Figura 4.5: Domínio utilizado para a modelagem com o MIKE 21 SW. ................................................42

Figura 5.1: Histogramas direcionais de onda para toda série temporal. Esquerda: Altura Significativa (m);

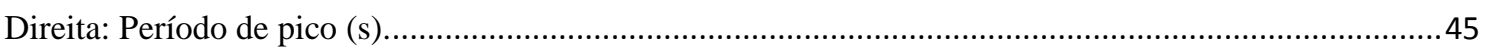
Figura 5.2: Gráfico de dispersão entre a altura significativa e o período de pico, considerando toda série de dados, com contornos referentes à porcentagem de ocorrência (centro com 8\% e extremos com 1\%). 45 Figura 5.3: Histogramas direcionais de onda para cada estação do ano. Esquerda: Altura Significativa (m); Direita: Período de pico (s) ...............................................................................................47 Figura 5.4: Gráfico de dispersão entre a altura significativa e o período de pico, considerando as diferentes estações do ano, com contornos referentes à porcentagem de ocorrência (centro com $8 \%$ e

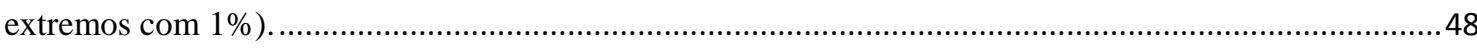

Figura 5.5: Distribuição média mensal dos valores de força de onda, a partir da série temporal de 30 anos.

.. 50

Figura 5.6: Distribuição da deriva litorânea potencial considerando a subdivisão espacial de setores adotada. Os valores são adimensionais. . .51 Figura 5.7: Distribuição longitudinal da deriva potencial, evidenciando a tendência geral de transporte a partir de regressão polinomial. Os valores são adimensionais. ...........................................................52 Figura 5.8: Variação sazonal da distribuição da deriva potencial, a partir da distribuição espacial de setores. Os valores são adimensionais...................................................................................54 Figura 5.9: Variações sazonais da deriva litorânea potencial, considerando as tendências gerais elaboradas a partir de regressão polinomial. Os valores são adimensionais..........................................................55 Figura 5.10: Distribuição de força de onda ao longo da costa da Ilha Comprida, considerando a série de

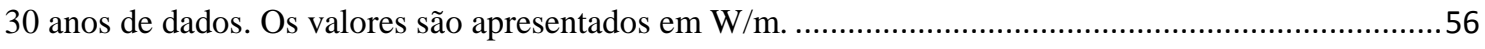
Figura 5.11: Distribuição espacial da força de onda ao longo da costa da Ilha Comprida, a partir de uma subdivisão sazonal da série de 30 anos de dados. Os valores são apresentados em W/m ........................57 Figura 5.12: Secção longitudinal dos valores de força de onda ao longo da costa da ilha comprida. O eixo y representa a força de onda, enquanto que o eixo x representa o eixo SW/NW da Ilha Comprida..........57 Figura 5.13: Histogramas direcionais das ondas que atuaram durante o período A. Direita: Altura significativa (Hs), em metros. Esquerda: período de pico (Tp), em segundos. ....................................60 Figura 5.14: Histogramas direcionais das ondas que atuaram durante o período B. Direita: Altura Significativa (Hs), em metros. Esquerda: Período de pico (Ts), em segundos......................................61 Figura 5.15: Histogramas direcionais das ondas que atuaram durante o período C. Direita: Altura significativa (Hs), em metros. Esquerda: Período de pico (Ts), em segundos.....................................62 
Figura 5.16: Histogramas direcionais das ondas que atuaram durante o período D. Direita: Altura significativa (Hs), em metros. Esquerda: Período de pico (Ts), em segundos......

Figura 5.17: Histogramas direcionais das ondas que atuaram durante o período E. Direita: Altura significativa (Hs), em metros. Esquerda: Período de pico (Ts), em segundos.....................................64

Figura 5.18: Distribuição da deriva potencial ao longo dos setores de análise para o período A...............65 Figura 5.19: Distribuição da deriva potencial ao longo dos setores de análise considerando apenas a

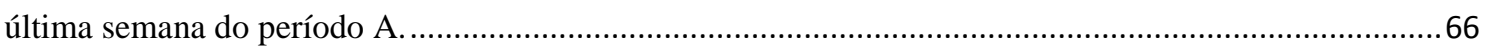
Figura 5.20: Distribuição da deriva potencial ao longo dos setores considerando o período B. ................66 Figura 5.21: Distribuição da deriva potencial ao longo dos setores considerando apenas a última semana

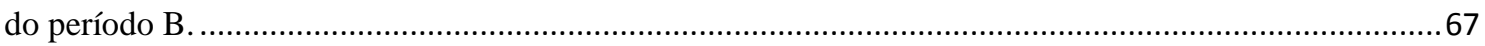

Figura 5.22: Distribuição da deriva potencial ao longo dos setores considerando o período C. .................68

Figura 5.23: Distribuição da deriva potencial ao longo dos setores considerando apenas a última semana

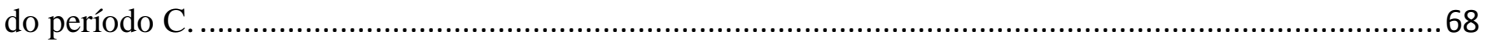

Figura 5.24: Distribuição da deriva potencial ao longo dos setores considerando o período D. .................69

Figura 5.25: Distribuição da deriva potencial ao longo dos setores considerando apenas a última semana

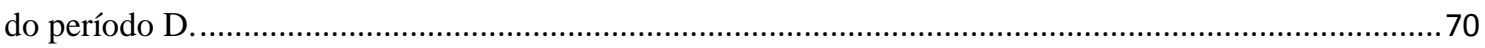

Figura 5.26: Distribuição da deriva potencial ao longo dos setores considerando o período E...................70

Figura 5.27: Distribuição da deriva potencial considerando apenas a última semana do período E. .........71 Figura 5.28: Deriva litorânea potencial média dos períodos analisados, com uma curva polinomial de

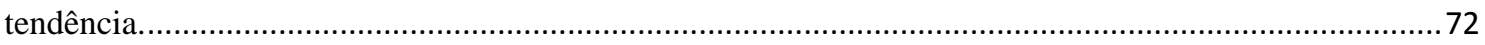

Figura 5.29: Distribuição de força de onda ao longo da costa da Ilha Comprida para o período A. ..........73 Figura 5.30: Distribuição de força de onda ao longo da costa da Ilha Comprida para a última semana do

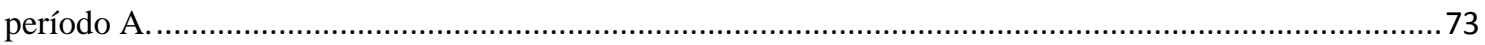

Figura 5.31: Variação longitudinal da força de onda para o período A inteiro e para a última semana, com suas curvas polinomiais de tendência...............................................................................................73

Figura 5.32: Distribuição de força de onda ao longo da costa da Ilha Comprida para o período B...........74 Figura 5.33: Distribuição de força de onda ao longo da costa da Ilha Comprida para a última semana do período B.

Figura 5.34: Variação longitudinal de força de onda para o período B e sua última semana, com suas curvas polinomiais de tendência................................................................................................75

Figura 5.35: Distribuição de força de onda ao longo da costa da Ilha Comprida para o período C............75 Figura 5.36: Distribuição de força de onda ao longo da costa da Ilha Comprida para a última semana do período C.

Figura 5.37: Variação longitudinal de força de onda para o período C e sua última semana, com suas respectivas curvas polinomiais de tendência. ...................................................................................76

Figura 5.38: Distribuição de força de onda ao longo da costa da Ilha Comprida para o período D. ..........77

Figura 5.39: Distribuição de força de onda ao longo da costa da Ilha Comprida para a última semana do período D.

Figura 5.40: Variação longitudinal de força de onda para o período D e sua última semana, com suas respectivas curvas polinomiais de tendência. Importante frisar o baixo $\mathrm{r}^{2}$ para a curva referente a última

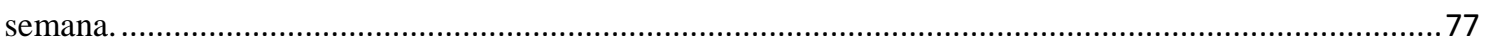

Figura 5.41: Distribuição de força de onda ao longo da costa da Ilha Comprida para o período E............78 Figura 5.42: Distribuição de força de onda ao longo da costa da Ilha Comprida para a última semana do período E.

Figura 5.43: Variação longitudinal de força de onda para o período E e sua semana, com suas respectivas

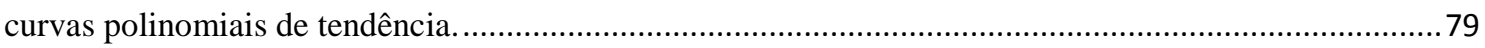

Figura 5.44: Imagem da ponta norte do Caminhamento 1 monitorado. .............................................8 80

Figura 5.45: Pequeno campo de dunas adjacente à região sul do Caminhamento....................................8 80

Figura 5.46: Foto de construção em fev/13 (acima) e maio/14 (abaixo), evidenciando o grau de recuo da

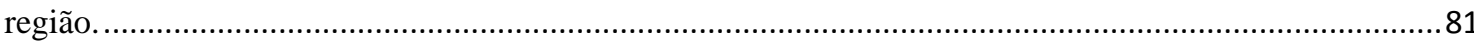

Figura 5.47: Imagem do Caminhamento 2, na porção mais ocupada da ilha. .......................................8 82 
Figura 5.48: Imagem do Caminhamento 3, na região central da ilha.

Figura 5.49: Imagem da face praial do Caminhamento 4, região centro-sul da ilha. ...............................84

Figura 5.50: Imagem do Caminhamento 5, região sul da ilha. .................................................................85

Figura 5.51: Distribuição espacial e temporal dos valores de diâmetro médio em cada compartimento

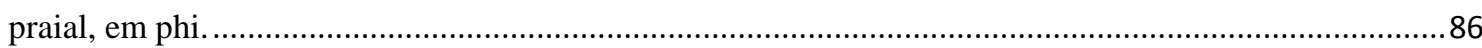

Figura 5.52: Distribuição espacial e temporal dos valores do grau de seleção em cada compartimento praial, em phi.

Figura 5.53: Mapa de variação altimétrica elaborado entre o último e o primeiro levantamento para o Caminhamento 1. As cores frias indicam erosão, enquanto as cores quentes, acresção.............................89 Figura 5.54: Acompanhamento da isolinha de altura de dois metros, evidenciando o recuo ocorrido no Caminhamento 1 ao longo do monitoramento......

Figura 5.55: Mapa de variação altimétrica elaborado entre o último e o primeiro levantamento para o Caminhamento 2. As cores frias indicam erosão, enquanto as cores quentes, acresção............................91 Figura 5.56: Mapa de variação altimétrica elaborada entre o último e o primeiro levantamento para o Caminhamento 4. As cores frias indicam erosão, enquanto as cores quentes, acresção.............................92 Figura 5.57: Mapa de variação altimétrica elaborado entre o último e o primeiro levantamento para o Caminhamento 5. As cores frias indicam erosão, enquanto as cores quentes, acresção...........................93 Figura 5.58: Mapa de variação altimétrica elaborado entre o último e o primeiro levantamento para o Caminhamento 6. As cores frias indicam erosão, enquanto as cores quentes, acresção.............................94 Figura 5.59: Perfis praiais e sua variabilidade em relação aos diferentes períodos para o Caminhamento

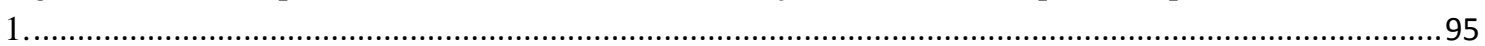

Figura 5.60: Perfis praiais e sua variabilidade em relação aos diferentes períodos para o Caminhamento 2. .......

Figura 5.61: Perfis praiais e sua variabilidade em relação aos diferentes períodos para o Caminhamento 4.......

Figura 5.62: Perfis praiais e sua variabilidade em relação aos diferentes períodos para o Caminhamento 5.

Figura 5.63: Perfis praiais e sua variabilidade em relação aos diferentes períodos para o Caminhamento 6. ..96

Figura 5.64: Gráfico da variação do volume normalizado para cada caminhamento, evidenciando tanto a

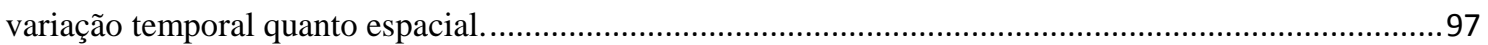
Figura 6.1: Setorização dos locais de erosão ao longo da Ilha Comprida (adaptado de Sousa (2013))......99 Figura 6.2: Variação do azimute ao longo da costa ca Ilha Comprida, evidenciando o aumento de azimute em direção ao norte. As barras azuis indicam acréscimo dos valores de azimute em relação ao setor ao sul adjacente. A linha preta evidencia o valor de azimute. 101 Figura 8.1: Mapas de variação altimétrica referentes ao Caminhamento 1. As letras indicam os períodos utilizados para o cálculo (final - inicial). 126

Figura 8.2: Mapas de variação altimétrica referentes ao Caminhamento 2. As letras indicam os períodos utilizados para o cálculo (final - inicial). 127

Figura 8.3: Mapas de variação altimétrica referentes ao Caminhamento 4. As letras indicam os períodos utilizados para o cálculo (final - inicial). 128

Figura 8.4: Mapas de variação altimétrica referentes ao Caminhamento 5. As letras indicam os períodos utilizados para o cálculo (final - inicial). 129

Figura 8.5: Mapas de variação altimétrica referentes ao Caminhamento 6. As letras indicam os períodos utilizados para o cálculo (final - inicial). .130 


\section{ÍNDICE DE TABELAS}

Tabela 4.1: Nomenclatura utilizada para representar cada levantamento, bem como as características gerais encontradas na data de cada coleta.

Tabela 5.1: Estatística descritiva das ondulações de água profunda encontradas para os 30 anos de análise.

Tabela 5.2: Frequência de ocorrência das ondulações de água profundas mais energéticas para a série temporal de 30 anos.

Tabela 5.3: Número de ocorrência de sistemas frontais ao longo da América do Sul, qualquer região da costa brasileira, e especificamente no litoral sul paulista, com distribuição temporal mensal. .58

Tabela 5.4: Estatística descritiva dos dados de onda referente ao período entre os diferentes levantamentos de campo.

Tabela 5.5: Estatística descritiva dos dados de onda referentes a semana anterior ao levantamento de campo. .64

Tabela 5.6: valores médios e desvio padrão do diametro médio e grau de seleção, separados por trecho. Valores em phi 86

Tabela 5.7: Sumarização dos dados referentes ao Caminhamento 1 ........................................................90

Tabela 5.8: Sumarização dos dados para o Caminhamento 2 ....................................................................90

Tabela 5.9: Sumarização dos dados para o Caminhamento 4 ..................................................................91

Tabela 5.10: Sumarização dos dados para o Caminhamento 5 ................................................................99

Tabela 5.11: Sumarização dos dados para o Caminhamento 6..........................................................93

Tabela 6.1: Sumarização dos dados de onda e variação volumétrica para os diferentes campos e

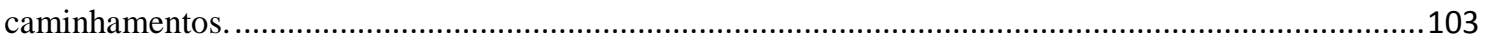

Tabela 8.1: Dados granulométricos referentes ao período A. As posições espaciais são aproximadas....120

Tabela 8.2: Dados granulométricos referentes ao período B. As posições espaciais são aproximadas. ...121

Tabela 8.3: Dados granulométricos referentes ao período C. As posições espaciais são aproximadas....122

Tabela 8.4: Dados granulométricos referentes ao período D. As posições espaciais são aproximadas....123

Tabela 8.5: Dados granulométricos referentes ao período E. As posições espaciais são aproximadas. ...124 


\section{Agradecimentos}

Muitos são os motivos para agradecer quando se encerra mais uma etapa de nossa curta vida:

- Primeiramente agradeço a Deus pela graça imerecida, pela presença e pelo amor.

- Aos meus pais e familiares, que me deram o suporte e o amor de sempre.

- Ao Prof ${ }^{o}$ Eduardo Siegle, pela orientação, companheirismo e exemplo acadêmico.

- Ao professor e ex-orientador Moysés G. Tessler e Paulo Polito pelo apoio e confiança.

- Aos amigos do NNT, por sempre estarem presentes em todos os momentos. Um abraço ao Douglas, Thiago, Heber, Jow, Jojo, Lipe, Marcus, Cabeça, Thales, Joás.

- Aos amigos e companheiros de laboratório, pela ajuda nos campos, nas discussões dos dados, nos cafés e momentos de descontração. Meu grande abraço ao PH, Lilian, Bruna, Juliana Damasceno, Juzinha, Hélio, Mirella, Caio, Pedro, Bárbara, Débora, Luan, Julia.

- Aos amigos de IO, pela amizade. Obrigado Renato, Biló, Mestre, Nancy, Diana, Thico, Natasha, Iole, Laís, Hanna.

- Aos amigos da igreja, pelo apoio e carinho.

- Ao Corinthians e E.C. Pinheiros.

- Ao $\mathrm{CNPq}$ e Instituto Oceanográfico, pelo auxílio financeiro e suporte à pesquisa.

- A minha querida namorada Stephanie, por sempre mostrar que podemos ir muito além do que nossos olhos podem imaginar.

Sou grato de coração a todos vocês. Provavelmente tenha esquecido alguém, mas não por mal. Espero e creio que eu tenha demonstrado a todos minha gratidão em algum momento.

“ Pois estou bem certo de que nem a morte, nem a vida, nem anjos nem demônios, nem o presente, nem o porvir, nem quaisquer poderes, nem altura, nem profundidade, nem qualquer outra coisa na criação será capaz de nos separar do amor de Deus que está em Cristo Jesus, nosso Senhor"

Romanos 8: 38-39-Bíblia Sagrada. 


\section{RESUMO}

O objetivo deste trabalho é avaliar as variações espaço-temporais da dinâmica morfosedimentar do sistema praial de Ilha Comprida-SP. Assim, para reconhecer os padrões de onda encontrados na região, resultados do modelo global de ondas WAVEWATCH III foram utilizados. Da mesma forma, levantamentos de campo periódicos foram realizados em cinco diferentes setores com obtenção de dados morfológicos e sedimentares. Simulações com o modelo numérico MIKE21 SW foram realizadas para reconhecer as tendências de transporte e distribuição de força de onda. Os resultados mostraram uma tendência geral de transporte para NE, com maiores valores para a região sul em relação a norte, com dois setores principais de divergência residual: centro-sul e norte. A divergência centro-sul apresenta um aumento e uma migração para sul nos meses mais energéticos, enquanto que a divergência norte apresenta uma manutenção espacial ao longo das estações. A distribuição de força de onda mostrou-se mais elevada nos setores centro-sul e norte, coincidindo com os pontos de divergência. Dados granulométricos mostraram baixa variabilidade temporal, mas possuem diferenças espaciais que refletem a hidrodinâmica local. Os dados volumétricos apresentam maiores valores médios nos setores centro-norte e menores no centro-sul e norte. De modo geral, os resultados mostram que ao longo de uma linha de costa exposta a um mesmo padrão de ondas, sua variabilidade é um reflexo de alterações hidrodinâmicas locais. Tais conclusões são importantes para o conhecimento do estado atual das praias e de sua evolução.

Palavras-chave: deriva litorânea, erosão costeira, morfodinâmica praial, DGPS. 


\begin{abstract}
The aim of this study is to evaluate the spatial-time variations on the beach system of Ilha Comprida-SP. Therefore, the wave reanalysis database from the global wave generation model WAVEWATCH III was used to recognize the wave pattern for the region. Furthermore, periodic field works at five different sectors have been conducted to collect morphological and sedimentological data. The numerical model MIKE $21 \mathrm{SW}$ has been applied to propagate waves onshore and recognize the transport tendency and the nearshore wave power distribution. Results show a transport trend to the NE, with the southern sector being larger than the northern sector in magnitude, with two main residual longshore drift divergence spots: in the central-southern and northern regions. Moreover, the central-southern divergence spot become larger and migrated to the south during the most energetic months, while the northern divergence spot kept its position throughout the year. Wave power results show two main areas with higher values that coincide with the observed longshore divergence spots. Sediment data presents low temporal variability, although spatial variations have been found reflecting the hydrodynamic conditions. The volumetric data shows largest values in the centralnorthern sector, being smaller in the central-southern and northern regions. In summary, the findings show that along this wide open stretch of coastline, exposed to the same offshore wave regime, its variability is a result of local hydrodynamic conditions. These results help in further understanding the island's long term evolution and current state of its beaches.
\end{abstract}

Keywords: longshore drift, coastal erosion, beach morphodynamic, DGPS. 


\section{INTRODUÇÃO}

Ambientes costeiros são locais de interface entre o oceano e as áreas emersas. Por essa razão, trata-se de uma região condicionada por uma grande gama de variáveis físicas, que compõe e integra os diferentes subambientes deste local de transição. Os aspectos hidrodinâmicos, como a ação de ondas formadas pelo vento e a ação das marés, exercem forte influência no âmbito de condicionar a dinâmica sedimentar destas áreas. Segundo Komar (1998), as ondulações formadas pelo vento em alto mar são as principais formas de entrada de energia na zona costeira, sendo responsável pela formação de correntes próximas à costa, bem como pelo transporte de sedimentos, regulando os processos modeladores da morfologia de tais ambientes. Como consequência da ação de ondas na interface continente-oceano, uma das possíveis feições proeminentes formadas são as chamadas praias.

Dentre várias definições usadas para definir ambientes praiais, um dos conceitos mais utilizados foi o proposto por King (1972), "Praias são ambientes sedimentares costeiros, formados mais comumente por areias de constituição variada, estendendo-se desde onde se inicia a interferência da velocidade orbital das ondas sobre o fundo marinho, até o limite mais continental da ação de ondas de tempestade ou mudanças fisiográficas bruscas".

As praias possuem diferentes formas, tamanho e composição, sendo tais características regidas basicamente pela característica geológica da fonte matriz de sedimentos, a proximidade do ambiente transicional com o fornecedor dos sedimentos e a interação dos sedimentos com processos físicos modeladores, como ondas e ventos. Deste modo, é possível reconhecer sua alta variabilidade e, consequentemente, sua sensibilidade de resposta devido a alterações em qualquer destas variáveis em diferentes escalas.

Considerando o caráter dinâmico desses ambientes, a atual tendência social de migração para regiões próximas a zonas costeiras deve ser avaliada de forma profunda e coesa para seu uso sustentável. Estimativas dizem que cerca de $60 \%$ da população deverá residir a menos de $60 \mathrm{~km}$ da costa (UNCED, 1992). O crescimento demográfico, juntamente com o pouco planejamento ocupacional, tem comprometido a qualidade ambiental destes ambientes, o qual consequentemente tem sido utilizado de maneira 
desordenada, acarretando assim em problemas tanto de cunho social e econômico, quanto de cunho ambiental.

A problemática do uso de ambientes praiais, através de diversas ações danosas como eliminação de dunas para construção civil e o nivelamento e limpeza mecânica de praias, podem trazer diversas consequências em diferentes escalas tanto para o ambiente em si quanto para o homem, através desde impactos biológicos significativos até variações de tendências de acúmulo e perda de sedimentos (Nordstrom, 2010).

Neste contexto, o conhecimento qualitativo e quantitativo dos processos naturais atuantes e condicionantes de um ambiente praial faz-se necessário para compreensão da influência do homem no local, fornecendo subsídios necessários para o desenvolvimento de medidas aplicáveis para o uso sustentável. Deste modo, a aplicação de estudos específicos diretos e indiretos, considerando as diferentes escalas atuantes, mostra-se de extrema importância para qualquer atividade a ser realizada, seja esta de cunho econômico, recreacional ou ambiental. Considerando o presente estudo, duas vertentes serão abordadas para a área: a morfodinâmica praial e a erosão costeira.

\subsection{Morfodinâmica Praial}

Dentre os diversos campos a serem abordados para a construção destes conhecimentos, a morfodinâmica praial mostra-se cada vez mais fundamental para a compreensão dos processos e suas variações em diferentes escalas de análise. Segundo Calliari et. al. (2003), a morfodinâmica praial pode ser definida como um método de estudo integrado entre observações morfológicas e dinâmicas, favorecendo uma descrição mais completa do ambiente e suas respostas. Gradientes espaciais e temporais no transporte de sedimentos praiais causados por forçantes hidrodinâmicas ocasionam mudanças morfológicas que, consequentemente, induzem modificações nos padrões hidrodinâmicos, num processo de retroalimentação permanente.

Inúmeras classificações foram propostas para setorizar os ambientes de uma praia. Tessler \& Mahiques (2000) propuseram uma terminologia referente aos setores praiais, a qual foi utilizada no presente trabalho (Figura 1.1). 


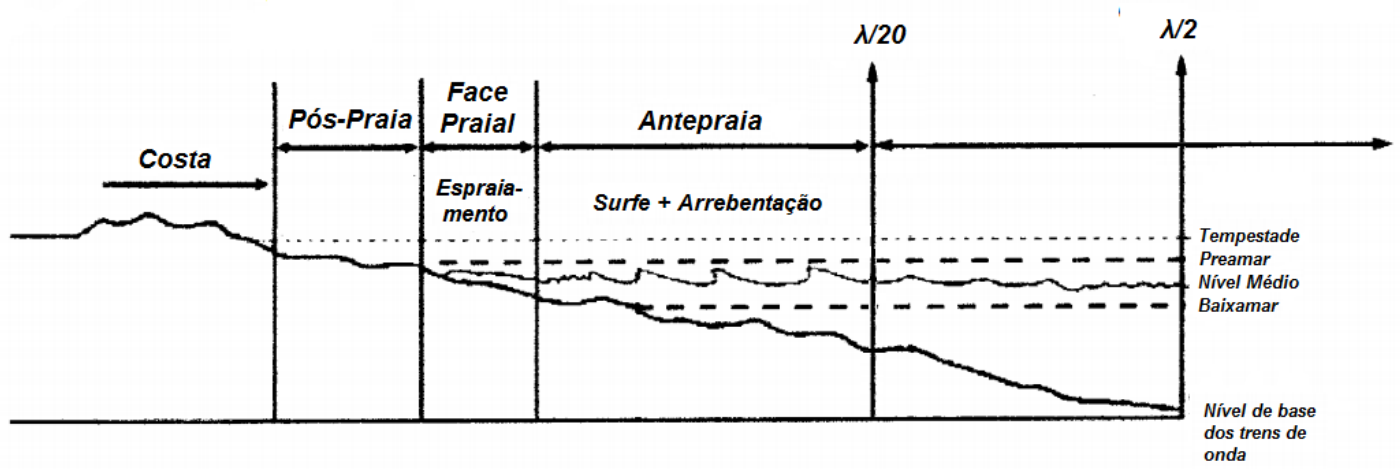

FIGURA 1.1: Terminologia Dos Setores De Uma Praia. Adaptado De Goya \& Tessler (2000)

Num contexto global, estudos específicos em morfodinâmica de praia têm sido desenvolvidos em vários países, com ênfase nos trabalhos realizados nos Estados Unidos, Austrália, Holanda e Inglaterra. Dentre os estudos clássicos, destacam-se os desenvolvidos por Wright et. al. (1979), comparando através de medidas de campo diferentes sistemas praiais refletivos e dissipativos, ambos situados em uma mesma região condicionada por um mesmo clima de ondas de alta energia, na costa australiana; Wright et. al. (1982), em estudo específico sobre os processos morfodinâmicos de uma praia de macromaré; Wright \& Short (1984), os quais refinam uma classificação morfodinâmica de praias, sendo reconhecidos assim dois estágios extremos (refletiva e dissipativa), e quatro estágios intermediários, sendo cada um dos seis padrões associados a diferentes regimes hidrodinâmicos; Anthony (1998), que explicita os problemas na utilização de alguns parâmetros para a definição de estágios morfodinamicos, propondo o uso de outras variáveis tanto hidrodinâmicas quanto sedimentares; Masselink \& Short (1993), que propõem um modelo conceitual para definição do estado morfodinâmico integrando aos parâmetros vigentes a forçante relativa à maré.

Recentemente, podem-se salientar os desenvolvidos por Jackson et. al. (2005), que comparando os modelos de previsão de estágio morfodinâmicos com medições na Irlanda, evidenciaram a conjunta importância de fatores geológicos para a morfologia e dinâmica praial; Ranasinghe et. al. (2004), com a utilização de metodologias de imagem e modelagem para a compreensão da dinâmica praial associada a praias intermediárias; Quartel et. al. (2008), que avaliam quantitativamente a variabilidade volumétrica de uma praia através de métodos de imagem e medições in situ, evidenciando padrões sazonais de variação; Masselink \& Puleo (2006), que focalizam seu estudo avaliando variações morfodinâmicas apenas na zona de espraiamento, considerando assim uma escala de análise menor. 
No Brasil, estudos específicos têm se mostrado relativamente escassos apesar de sua extrema importância devido as diferentes escalas de atuação e resposta envolvidas. É possível reconhecer uma predominância de trabalhos pontuais concentrados basicamente na região Sul e Sudeste, bem como nos estados da Bahia e Ceará, com destaque para as sínteses realizadas por Hoefel (1998) e Calliari et. al. (2003); o trabalho desenvolvido por Muehe (1998) que, avaliando praias no estado do Rio de Janeiro através da integração de diversos parâmetros, propõe uma nova abordagem para determinação do estado morfodinâmico pontual de um sistema praial; o trabalho de Oliveira (2004) na Ilha de Santa Catarina, onde foi realizado um monitoramento anual reconhecendo quantitativamente flutuações sazonais no estoque sedimentar no arco praial Pântano do Sul.

No estado de São Paulo, poucos estudos com este enfoque têm sido realizados, destacando-se os trabalhos de Cazzoli (1997), que em estudo realizado no litoral sul, reconheceu a forte influência da passagem de sistemas frontais na dinâmica praial da região; Martins (2000), que observa a influencia do Anticiclone Polar móvel na variabilidade morfológica da praia de Bertioga; Martins (2006), que em estudo específico na praia da Sununga, litoral norte de São Paulo, atribui as variações morfosedimentares ao processo de rotação praial observado na área. Na região da Ilha Comprida, alguns estudos podem ser evidenciados, como Nascimento (2006), o qual em estudo envolvendo conceitos de morfodinâmica, granulometria e mineralogia, interpretou, dentre outras conclusões, a presença de duas células divergentes de deriva litorânea ao longo da praia da Ilha Comprida, bem como a setorização da Ilha em relação a seu estágio morfodinâmico e associação morfológica entre as dunas frontais e a praia ao longo da ilha; Marquez (2010) avaliou as variações morfológicas e volumétricas de curto período em um segmento de praia na porção sul da ilha, reconhecendo padrões de onda que atuaram tanto em processo erosivo quanto de engordamento em uma escala diária a sazonal. Entretanto, tendo em vista os diferentes setores praiais ao longo da ilha, não se sabe se os mesmos padrões de variação encontrados por Marquez (op. cit.) se mantém ao longo de toda a extensão da Ilha Comprida, nem se os padrões de ondas que tiveram papel na erosão e deposição do trecho sul teriam o mesmo papel nos diferentes trechos. Além disso, não se conhece a variabilidade desta divergência encontrada por Nascimento (2006). Assim, estudos integrativos entre diferentes escalas, abordando o sistema praial de Ilha Comprida como 
um todo se mostram necessários para a real compreensão dos processos presentes na região.

A importância do conhecimento da morfodinâmica praial, considerando todas as escalas de análise, é imprescindível para a ocupação de áreas próximas, bem como o uso sustentável pela população permanente e flutuante de regiões costeiras. Flutuações volumétricas e alterações no padrão dinâmico praial, os quais podem ser condicionados tanto por ação natural quanto antrópicas, devem ser avaliadas e conhecidas, tanto qualitativamente quanto quantitativamente, para o manejo social, econômico e ambiental.

\subsection{Erosão Costeira}

A erosão costeira é um problema que tem afetado grande parte das regiões litorâneas em todo mundo em diferentes escalas temporais e espaciais. Algumas estimativas colocam que em todo globo, $70 \%$ das costas sofrem com essa questão (Davis Jr \& Fitzgerald, 2004; Bird, 2008), sendo delineada por processos naturais como aumento do nível do mar, agravamento de tempestades e marés meteorológicas, subsidência tectônica e alterações na bacia hidrográfica; e antrópicas, como a subsidência do terreno, construção de barragens e retirada de material para construção civil, por exemplo (Cai et.al. 2009).

$\mathrm{Na}$ Europa, cerca de $40 \%$ das praias tem apresentado processos erosivos, gerando gastos de cerca de 3 milhões de euros com ações mitigatórias em 2001, com estimativas de aumento em cerca de $70 \%$ dos investimentos anuais até 2020 (EUROSION, 2004). Na América do Norte, diversos trabalhos podem ser citados explicitando o problema da erosão na região, como por exemplo, Allan \& Komar (2006), evidenciando os efeitos de processos globais e climáticos interanuais no aumento da altura de ondas e do nível relativo do mar, e sua consequente relação com processos erosivos na costa oeste americana; e Dolan et. al. (1977), que avalia a possiblidade do uso de fotografia aéreas para avaliação de longo termo de processos erosivos na costa de Nova Jersey.

No panorama brasileiro, tal fenômeno também possui relevância, com o predomínio do processo erosivo ao longo da costa brasileira (Muehe, 2006). Na costa sul, Dillenburg et. al.(2004) realizaram um estudo denotando no balanço negativo de sedimentos como o principal definidor da erosão nas diferentes escalas temporais 
abordadas ao longo da costa do Rio Grande do Sul. Já na costa nordeste, Souza (2008) analisa os benefícios de obras de contenção do tipo bagwall nos aspectos mitigatórios envolvidos com o problema, elucidando a influencia do processo em questões sociais e econômicas. Morais et. al.(2008), em estudo no município de Fortim (CE), reconheceu uma relação direta entre a diminuição da vazão do rio Jaguaribe após a construção de um açude e o aumento da taxa de recuo da linha de costa na região.

O estado de São Paulo não apresenta processos generalizados de erosão costeira ao longo de seus aproximados $400 \mathrm{~km}$ de extensão (Muehe, op. cit.), possuindo alguns focos restritos de tendências erosivas, como por exemplo, a praia de Massaguaçú, em Caraguatatuba-SP, a praia da Juréia e no município de Ilha Comprida, litoral sul de São Paulo. Estudos têm sido feitos nas regiões de modo a compreender os processos e sua relação com os riscos inerentes à população local. Ribeiro et. al. (2013) avaliaram a evolução da vulnerabilidade à erosão costeira na praia de Massaguaçu, que apesar de se mostrar praticamente constante, se manteve elevada principalmente na região central da praia, foco dos processos erosivos intensos. Sousa et. al. (2013) validou sua proposta de índice a vulnerabilidade costeira na mesma praia, também encontrando maiores valores na região de erosão. Entretanto, para a região de Ilha Comprida, estudos referentes à erosão costeira têm sido escassos, com o exemplo dos trabalhos de Souza e Suguio (1996, 2003), que abordam os processos erosivos e as zonas de risco ao longo da costa paulista, incluindo a região da ilha, e Souza (1997), que através de estimativas de transporte a partir de métodos granulométricos, define tendências de transporte para a costa paulista.

Souza e Suguio $(1996,2003)$ e Souza (1997) caracterizaram duas regiões predominantes de erosão ao longo das praias de Ilha Comprida: uma na região centrosul e outra na região norte, sendo ambas associadas à divergência na deriva litorânea em tais regiões. Entretanto, não se sabe quantitativamente quais as tendências de transporte longitudinal ao longo da ilha, fator importante para as variações em diferentes escalas e para compreensão do recuo na ilha. Sousa (2013) em estudo envolvendo índices de vulnerabilidade realizou estimativas de força de onda e deriva litorânea potencial para Ilha Comprida a partir do mês com maiores entradas de frentes frias, reconhecendo que as regiões erosivas podem estar associadas não só com a deriva litorânea como reconhecido por Souza (1997) e Nascimento (2006), mas também com a variabilidade espacial da força de onda no local. Entretanto, tal estimativa não considera a 
variabilidade sazonal nem a tendência de transporte e força de onda, não considerando os possíveis processos de recuperação envolvidos.

Deste modo, a identificação quantitativa dos processos que delineiam a erosão no local, bem como sua variabilidade em diferentes escalas, mostra-se necessária para a compreensão do fenômeno na região e para processos de ocupação e planejamento. 


\section{OBJETIVOS}

O objetivo do presente trabalho está centrado na avaliação descritiva das variações espaço-temporais em diferentes trechos da praia de Ilha Comprida, a partir do acompanhamento da variabilidade morfológica e sedimentar, bem como do reconhecimento das tendências de transporte longitudinal ao longo da ilha e do clima de ondas, considerando as diferentes escalas temporais dos processos atuantes.

Os objetivos específicos para a elaboração do trabalho são:

- Avaliação da evolução topográfica e sedimentar das diferentes áreas ao longo da série temporal.

- Análise do clima de ondas na região e sua relação com aspectos meteorológicos e morfo-sedimentares.

- Reconhecimento das tendências de transporte de sedimentos na zona costeira, bem como da distribuição de energia ao longo do sistema praial. 


\section{3 ÁREA DE ESTUDO}

\subsection{Considerações Iniciais}

O litoral paulista é limitado entre $23^{\circ}$ e $25^{\circ}$ de latitude sul e entre $45^{\circ}$ e $48^{\circ}$ de longitude oeste, podendo ser dividido, sob o ponto de vista morfológico, em duas porções: uma ao norte, com o embasamento Pré-Cambriano atingindo o mar em quase toda a extensão; e outra ao sul, com o desenvolvimento de grandes planícies formadas essencialmente por depósitos marinhos ou flúvio-lagunares (Tessler, 1988). Suguio \& Martin (1978) dividiram o litoral paulista e sul fluminense em cinco áreas morfológicas principais, a partir de limites naturais de esporões do Embasamento Cristalino, sendo Cananéia-Iguape uma das unidades, cuja Ilha Comprida está inserida.

A planície costeira Cananéia-Iguape é a mais extensa do estado, composta basicamente por sedimentos quaternários arenosos, sendo estes homogêneos, compostos por areias finas muito bem selecionadas (Marquez, 2007). Nesta planície, houve o desenvolvimento do sistema lagunar chamado Complexo Estuarino Lagunar CananéiaIguape, o qual é composto em linhas gerais pelas ilhas de Cananéia, Ilha Comprida, Iguape e Cardoso; pelos canais lagunares: Ararapira, Mar de Cananéia, Mar Pequeno e Mar de Cubatão; pelas desembocaduras: Barra de Ararapira, Barra de Cananéia (principal acesso ao oceano do complexo) e Barra de Icapara; por rios de gamboa e pelos canais artificiais: Valo Grande e Varadouro (Bonetti Filho \& Miranda, 1997; Gagliardi, 2013; Sousa, 2013).

A Ilha Comprida possui cerca de $65 \mathrm{~km}$ de comprimento e 5,5km de largura e se estende desde a desembocadura de Icapara, ao norte, até a desembocadura de Cananéia, ao extremo sul. É predominantemente composta por sedimentos arenosos de idade quaternária, sendo a elevação rochosa denominada Morrete o único destaque no relevo, essencialmente baixo e plano, com altitudes inferiores a cinco metros (Tessler, 1988). Sua orientação geral acompanha a orientação padrão da costa sul paulista, delineada no sentido NE-SW, com todo seu sistema praial praticamente exposto para ondas provindas dos quadrantes SW, S, SE, E e NE.

Sua ocupação data desde a pré-história, com a presença de sambaquis, passando pela tentativa de formação de núcleo urbano na fase colonial, com a chegada de Martin Afonso de Souza e a colocação de um marco de pedra com as armas de Portugal na 
região de Cananeia. Atualmente, a construção da ponte Iguape-Ilha Comprida em 2000 favoreceu um aumento da proporção de crescimento da população na região, que atingiu taxas de crescimento próximas a 100\% entre os anos de 2000 e 2006 (Becegato \& Suguio, 2007). O setor norte é principal região de ocupação da ilha, relacionado com a proximidade com Iguape e pela construção da mesma ponte supracitada, enquanto que comunidades tradicionais, loteamentos para casas de veraneio e serviços relacionados ao turismo prevalecem na baixa região ocupada mais ao sul (Becegato \& Suguio, op.cit., Farinaceo, 2008, Gagliardi, 2013).

A Ilha Comprida está inserida na APA da Ilha Comprida, baseada na lei federal $n^{\circ} 6.938 / 81$, a qual foi instituída pela lei estadual $n^{\circ} 6.902 / 81$. Tal APA foi aprovada em 11/03/1987, com a edição do decreto estadual $n^{\circ} 26.881$. Os principais aspectos que culminaram para a criação desta APA foram: a importância da área como refúgio de recursos genéticos de espécies marinhas; dinâmica atual intensa de sedimentação e erosão costeira; ocorrência de organismos passíveis de criação na região do mar pequeno; proteção do Mar pequeno do oceano feita pela ilha-barreira de Ilha Comprida.

Atualmente, o município de Ilha Comprida possui uma população estimada em 10000 habitantes, compreendendo uma área territorial de aproximadamente $190 \mathrm{~km}^{2}$, resultando em uma densidade demográfica de aproximadamente 50 habitantes por $\mathrm{m}^{2}$, com uma economia baseada principalmente na prestação de serviços (IBGE, 2014). 


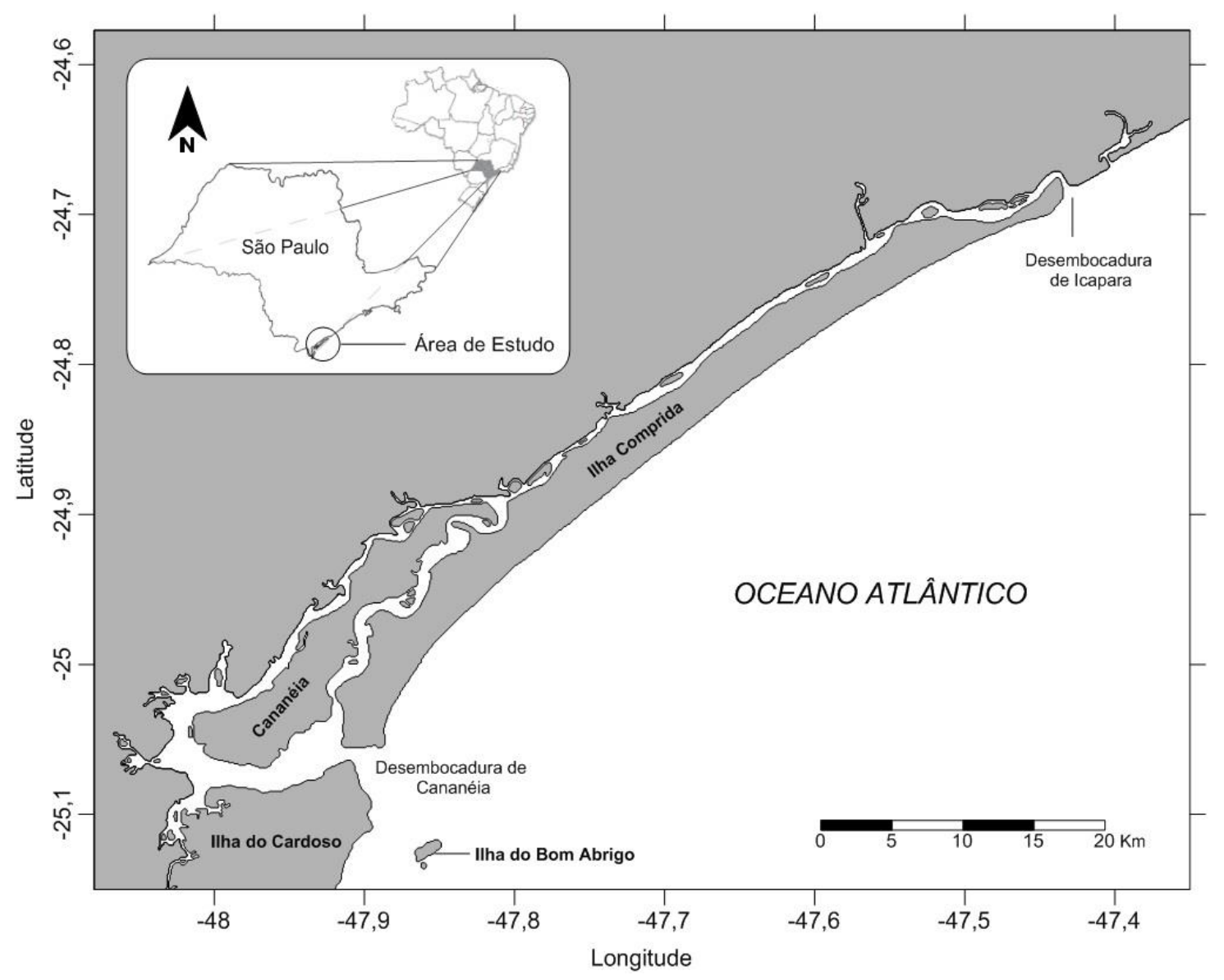

Figura 3.1: Localização espacial da área de estudo.

\subsection{Geologia e formação}

\subsubsection{Planície Cananéia-Iguape}

A presença da Serra do Mar, denominada como um conjunto de escarpas festonadas que se estendem desde o estado do Rio de Janeiro até Santa Catarina, atingindo altitudes máximas de 1800 metros e sendo constituída principalmente por rochas do Embasamento Cristalino de idade Pré-cambriana, caracteriza o litoral paulista através de seus constantes afloramentos e seu posicionamento aproximadamente paralelo a linha de costa (Tessler \& Goya, 2005; Almeida, 1976; Almeida \& Carneiro, 1998). Os processos tectônicos cenozoicos que ocorreram no estado de São Paulo estão relacionados com a elevação epirogenética pliocênica da Serra do Mar, sendo o soerguimento de tais sistemas montanhosos explicados por processos de movimentação verticais gerados a partir de reativações tectônicas descontínuas de idade Cretáceas e Terciárias (Almeida \& Carneiro, 1998; Almeida, 1976). O relevo atual da Serra do Mar pode estar associado tanto ao recuo erosivo das principais falhas de borda da bacia de 
Santos quanto a colapsos gravitacionais precedidos por soerguimento intraplaca do Cretáceo Superior (Almeida \& Carneiro, 1998; Zalan \& Oliveira, 2005).

A variação da proximidade de tais escarpas cristalinas da linha de costa gera significativas mudanças morfológicas ao longo do litoral paulista, a qual apresenta genericamente duas porções com características distintas: a porção norte e a porção sul. A porção norte é caracterizada pelo afloramento próximo a linha de costa atual, configurando um litoral recortado formado por pequenas planícies, compostas por sedimentos quaternários marinhos na sua parte externa e continental na sua parte interna, separadas por pontões que geralmente atingem a parte oceânica. A porção sul é caracterizada pelo desenvolvimento de grandes planícies costeiras formadas basicamente por depósitos marinhos flúvio-lagunares, estando o afloramento do maciço rochoso localizado a dezenas de quilômetros da linha de costa atual (Gagliardi, 2013; Marquez, 2007; Suguio \& Martin, 1978).

$\mathrm{Na}$ região sul do estado, onde se localiza nossa área de estudo, está situada a planície costeira denominada Cananéia-Iguape (Figura 3.2). A unidade de CananéiaIguape é formada por uma planície sedimentar costeira de formato aproximadamente triangular limitada a SW e NE por afloramentos do Embasamento Cristalino, constituindo uma área de $130 \mathrm{~km}$ por $40 \mathrm{~km}$ aproximadamente (Tessler, 1988). Segundo Farinaccio (2008), caracteriza-se por ser a região de maior desenvolvimento da sedimentação costeira Cenozoica no estado de São Paulo, sendo sua formação extremamente condicionada pelas variações do nível do mar durante o quaternário, as quais geraram eventos de regressão e transgressão que retrabalharam os sedimentos dispostos na região ao longo dos anos. 


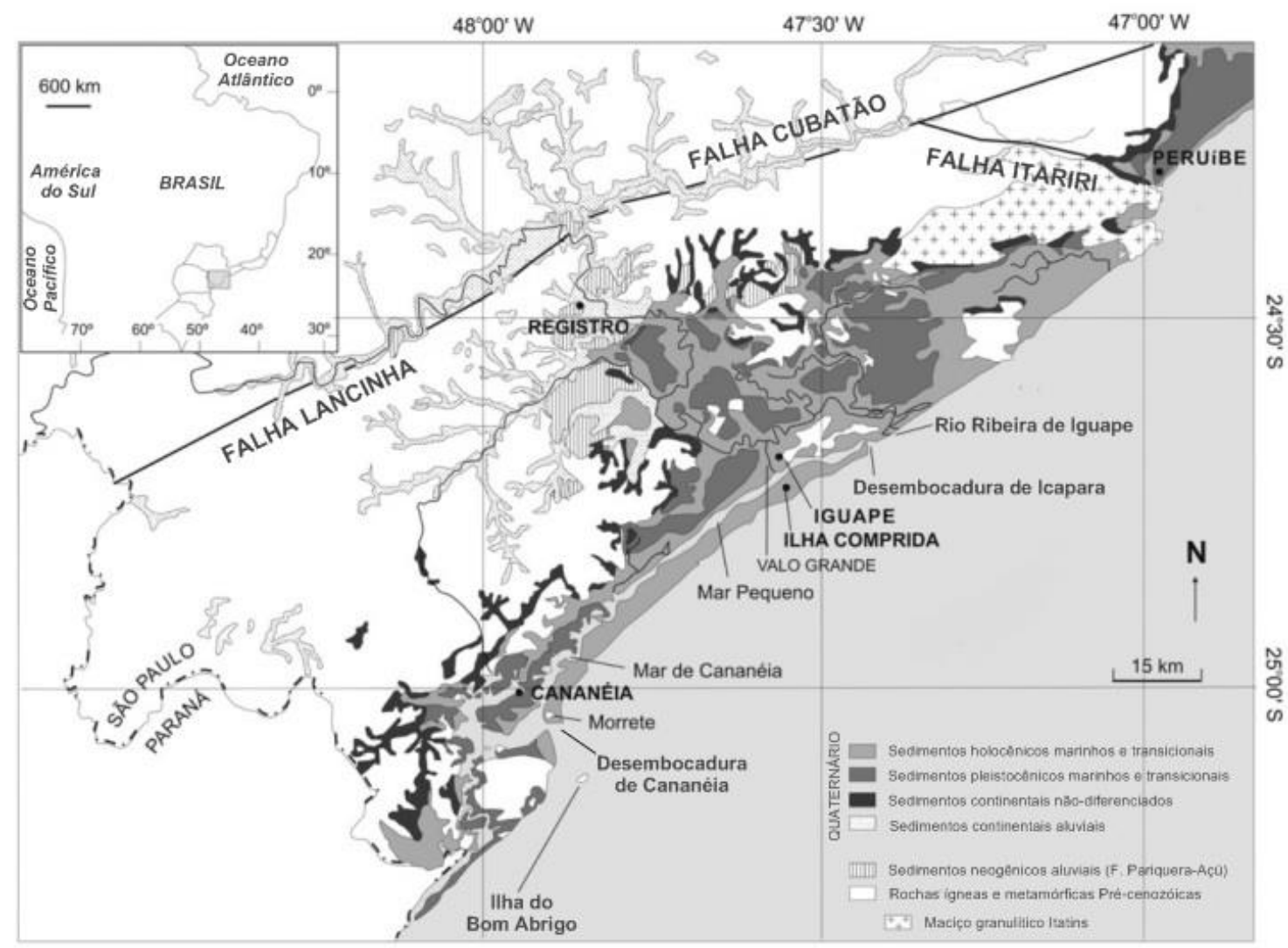

Figura 3.2: Mapa geológico da região, evidenciando os sedimentos que compõe a planície Cananéia-Iguape, bem como as principais falhas e afloramentos (adaptado de Guedes et.al., 2011).

A gênese e desenvolvimento da planície Cananéia-Iguape têm relação direta com dois principais eventos de variação do nível do mar ao longo do Quaternário: a Transgressão Cananéia e Transgressão Santos, sendo ambas de origem glácio-eustática. A primeira atingiu níveis de 8-10 metros acima do atual, com seu máximo transgressivo em torno de 120.000 anos A.P., e o subsequente máximo regressivo o qual atingiu níveis em torno de 110 metros abaixo do nível médio atual, por volta de 18.000 A.P.(Martin et. al., 1982). A segunda teve seu máximo transgressivo em torno de 5.100 A.P., atingindo níveis até 4-5 metros acima do atual (Martin et. al., 1985).

Três formações sedimentares compõe a planície, a saber: Formação PariqueraAçú, Formação Cananéia e Formação Ilha Comprida, sendo as duas últimas relacionadas a efeitos de variações do nível do mar. A Formação Pariquera-Açu está situada sobre o Embasamento Cristalino e sob a Formação Cananéia, sendo constituída por orto e paraconglomerados e por sedimentos argilosos e arenosos, atribuídos respectivamente a leques aluviais e depósitos fluviais e lacustres distalmente associados (Melo, 1990). Aflora na cidade homônima, sendo as evidências de sua idade inconclusivas, havendo debate entre diversos autores (Guedes, 2009). A Formação Cananéia, de idade pleistocênica, é descrita por três sequencias litológicas da base para 
o topo: sedimentos síltico-argilosos com espessura de até 14 metros; areias siltosas com espessura de até 12 metros; e areias finas muito bem selecionadas, com espessura de até 30 metros (Suguio \& Martin, 1978). A Formação Ilha Comprida, anteriormente denominada de Formação Santos (Suguio \& Tessler, 1992), é compreendida por depósitos sedimentares holocênicos, formados basicamente por areias marinhas finas e muito finas na forma de terraços cobertos por cordões litorâneos, depósitos arenoargilosos de origem fluvio-lagunar, e depósitos eólicos melhor representados na porção sul da Ilha Comprida (Suguio \& Martin, 1994).

Suguio \& Martin (1978) apresentam um modelo evolutivo da planície, subdividido basicamente em cinco estágios:

- $1^{\circ}$ Estágio: devido a transgressão Cananéia, o nível do mar atinge o sopé da Serra do Mar, possibilitando a deposição de argilas-arenosas transicionais e areias litorâneas transgressivas ao longo da planície, recobrindo os sedimentos da formação Pariquera-Açu'.

- $2^{\circ}$ Estágio: Com a subsequente regressão do nível do mar, cordões litorâneos são formados no topo dos depósitos arenosos.

- $3^{\text {o }}$ Estágio: Com o máximo regressivo, os sedimentos depositados durante a Transgressão Cananéia passam a ser erodidos pelo escoamento continental, sendo formados vales possivelmente parecidos com os encontrados na Formação Barreiras, no sul do Estado da Bahia.

- $4^{\circ}$ Estágio: A Transgressão Santos penetra as zonas baixas, formando extensas lagunas com deposição de sedimentos argilo-arenosos ricos em matéria orgânica e erodindo partes mais altas da Formação Cananéia, possibilitando a ressedimentação holocênica destes materiais.

- $5^{\circ}$ Estágio: a consequente regressão até níveis atuais, com a formação de cordões litorâneos de regressão de diferentes fases, devido a oscilações de menor escala.

\subsubsection{Ilha Comprida}

Segundo Suguio \& Martin (1978), baseado nos processos descritos acima, é possível sumarizar a evolução geológica da Ilha Comprida durante o Holoceno. Após o primeiro estágio de nível do mar (5500 AP), período o qual apenas a região do Morrete estava emersa, a ilha cresceu em direção a NE. Tal crescimento é percebido através de 
cristas praiais ao longo da porção mais interna da ilha atual. Durante um pequeno evento transgressivo (3500 AP), as cristas foram parcialmente erodidas, seguidas da construção das cristas praiais externas atuais.

Recentemente, Guedes et. al. (2011) propõe outro modelo de evolução para a Ilha Comprida, baseados em cinco fases distintas de evolução (Figura 3.3). Os autores apontam que a ilha começou como uma barreira transgressiva do Holoceno há 6000 anos antes do último máximo do nível relativo do mar. Após essa fase inicial, há uma progradação até 5000 A.P., com rápido crescimento tanto longitudinal quanto transversal, pela adição de cordões litorâneos. Entre 5000 e 1900 A.P., a evolução se deu de maneira branda, com baixa engorda transversal e longitudinal (5,2 a 6,9 metros/ano). A partir de 1900 A.P. até aproximadamente 500 A.P., um processo de engorda transversal de toda a ilha se estabelece, devido ao bloqueio longitudinal da ilha na porção NE, devido a presença dos morros próximos a Iguape. Depois de um relativo período de estabilidade entre 500 e 200 A.P., devido provavelmente à variações no regime de ventos e ondas, a ilha vence o obstáculo natural e volta a apresentar um crescimento longitudinal acelerado para NE, sendo tal situação presente até os dias atuais. Os autores ainda sugerem a intensificação deste processo após a abertura do canal artificial do Valo Grande e o aumento da capacidade de retenção de sedimentos devido ao efeito de molhe hidráulico. 


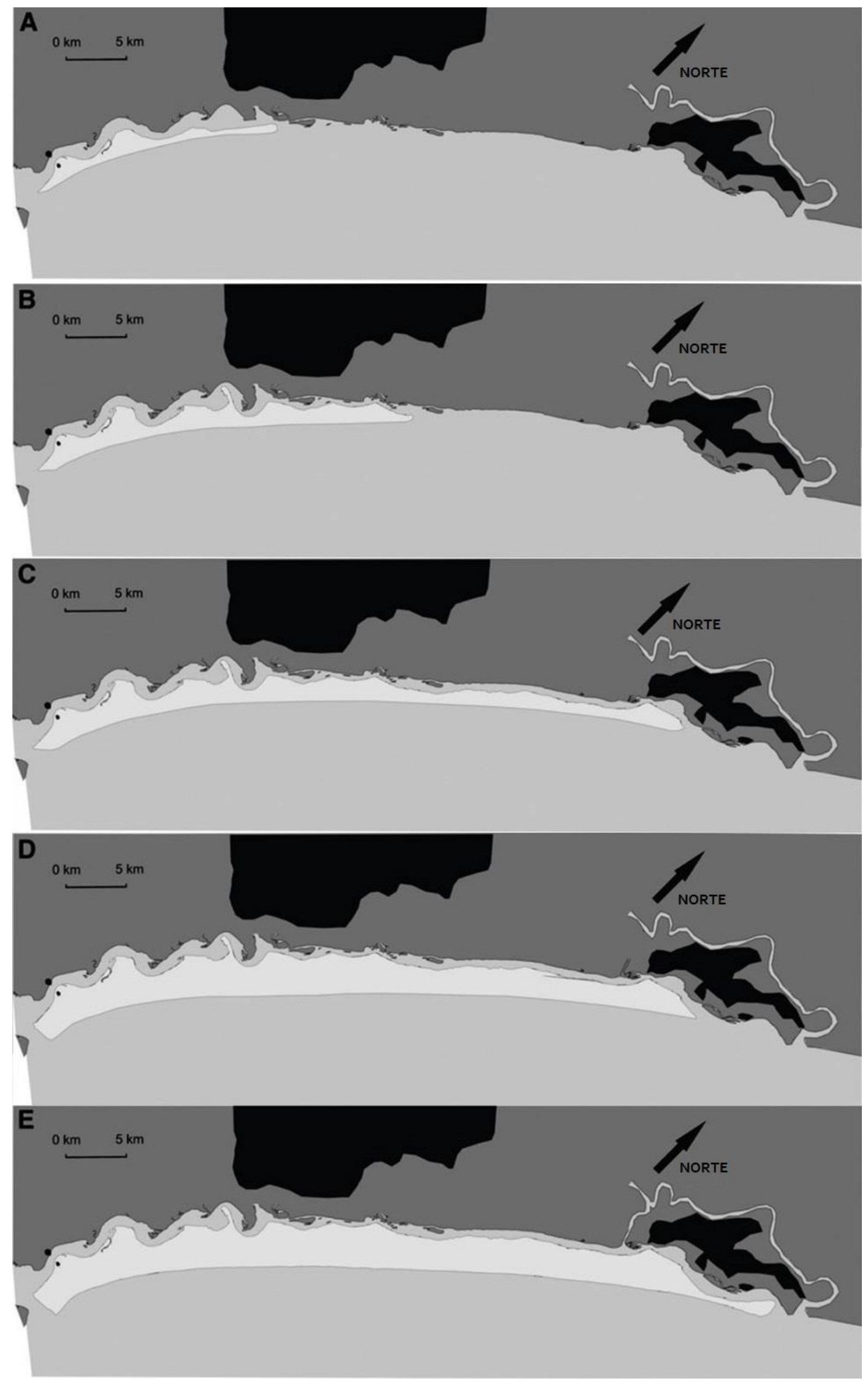

Figura 3.3: Modelo evolutivo para a ilha proposto por Guedes et. al. (2011), com cinco estágios de crescimento relacionados com variações do nível do mar relativo ao quaternário. A: Primeira fase (6000 AP); B: Segunda fase (5000AP); C: Terceira fase (1900 AP), D: Quarta fase (200 AP); E: Quinta fase (Presente). 


\subsection{Dinâmica atual}

\subsubsection{Sistema praial de Ilha Comprida}

A construção do conhecimento relacionado ao sistema praial da Ilha Comprida passa majoritariamente por alguns estudos que têm norteado a pesquisa em diferentes escalas nesse ambiente.

O primeiro grande trabalho a ser realizado que englobou o sistema praial na Ilha Comprida foi o de Barcelos (1975), o qual encontrou cinco subambientes deposicionais, a saber: eólico-dunas, praial, marinho raso - cordões litorâneos, marinho raso - praial e mangue e reconheceu, também, que a deposição dos sedimentos na face marinha tem ocorrido predominantemente na direção NE. Além disso, Barcelos (op. cit.) concluiu que, de modo geral, as praias da Ilha Comprida apresentam sedimentos compostos por areia fina, com baixa variação ao longo de seu sistema e com concentração de minerais pesados em certos locais.

Tessler (1988) apoiou hipótese de transporte para NE, tendo em vista o padrão de crescimento dos cordões litorâneos. $\mathrm{O}$ autor verificou a coexistência de dois sistemas de ondas subordinados a mecanismos meteorológicos da América do Sul que teriam importância para o transporte de sedimentos costeiros na região. Os trens de onda provenientes de S-SE geram correntes de deriva litorânea que se propagam em direção à região do litoral centro-sul paulista, NE, enquanto que as correntes de deriva litorânea com sentido SW, são geradas a partir de ondulações provindas dos quadrantes NE-E.

O trabalho de Souza (1997) forneceu novas perspectivas para a área e para os estudos em praias na região. A autora, em estudo acerca das células de deriva litorânea e erosão para o litoral paulista, encontra um padrão de deriva litorânea em escala regional mais complexo do que o sugerido por Barcelos (1975) e Tessler (1988), sugerindo a presença de duas células que formariam um centro de divergência na região centro-sul da ilha, apesar de manter a idéia de tendência geral para NE. Tal fator explicaria a presença de um foco de erosão nas praias da região centro-sul da Ilha, local que apresenta características praiais que sugerem um processo de erosão ativo.

Após um período com pouca produção relacionada às praias da região, Nascimento (2006) realiza um importante trabalho a partir de conceitos de morfodinâmica, granulometria e mineralogia dos sedimentos do sistema praia-duna. Seus resultados corroboraram com os encontrados por Souza (1997) acerca da deriva 
litorânea, utilizando-se de estimativas de transporte a partir das propriedades geoestatisticas dos sedimentos. Além disso, setorizou as praias da Ilha Comprida a partir de seu estágio morfodinâmico, com os primeiros $16 \mathrm{~km}$ de praia de sul para norte composta por praias com característica intermediária a dissipativa, seguida de um predomínio de praias com características morfodinâmicas dissipativas. Apesar de não se utilizar dos cálculos propostos por Wright \& Short (1984) para definição do estágio morfodinâmico, a caracterização visual forneceu subsídios para outros trabalhos com enfoque morfodinâmico.

O trabalho de Marquez (2007) foi o primeiro com enfoque morfodinâmico a considerar uma escala de processos sazonais. A autora estudou um trecho na porção sul da ilha, onde procurou avaliar a variabilidade sazonal do setor considerando o prisma subaéreo e submerso. Seus resultados mostraram padrões de deposição e erosão do perfil praial relacionadas a eventos meteorológicos, sendo o perfil mais erodido no inverno, com o aumento da passagem de sistemas frontais, e acrescido no verão, com o predomínio de ondulações de tempo bom. A autora ainda explicita as características de onda que atuaram tanto na remoção, quanto deposição de sedimentos no sistema praial, sendo que ondas de $\mathrm{E}$ de até $1 \mathrm{~m}$ de $\mathrm{Hs}$ atuaram na região como agentes de erosão, passando a favorecer processos deposicionais com o aumento da altura significativa. Em contrapartida, esse padrão se inverte para o quadrante $S$, onde ondas de até $1 \mathrm{~m}$ atuaram na deposição, e ondas maiores favoreceram a retirada líquida de sedimento. Seus resultados corroboraram com os encontrados por Nascimento (op. cit), em relação às características morfodinâmicas do trecho, que variaram de dissipativa no verão para dissipativa-intermediária no inverno.

Gagliardi (2013), em trabalho específico nas praias da região sul da ilha, bem como no setor interno ao canal da Barra de Cananéia, avaliou através de dados topográficos de campos, análises de evolução da linha de costa, simulações numéricas e determinação de cotas de inundação a resposta na evolução geomorfológica do setor costeiro frente às mudanças climáticas atuais. Seus resultados mostraram que, em escala diária, o transporte predominante nas praias foi onshore-offshore em direção ao mar, enquanto que em uma escala sazonal, seus resultados corroboraram com os encontrados por Marquez (2007).

Sousa (2013), em trabalho envolvendo aplicação de índices de vulnerabilidade para a zona costeira, realizou monitoramento de um trecho de praia no setor sul da Ilha Comprida, encontrando também respostas condizentes com os trabalhos de Marquez 
(2007) e Gagliardi (2013), onde as flutuações volumétricas dos perfis foram associadas a sazonalidade dos processos ondulatórios. Para este setor, o autor encontra um relativo padrão de estabilidade ao longo de seu monitoramento, sem nenhuma perda residual significativa de sedimentos no final da análise. $\mathrm{O}$ autor sugere que os focos de erosão encontrados ao longo do sistema praial podem estar associados não apenas a divergências na deriva litorânea, mas também a flutuações nos níveis de força de onda ao longo de toda a ilha.

\subsubsection{Sistemas atmosféricos}

A principal indutora dos processos costeiros em curto e médio prazo é o clima de ondas, os quais são coordenados pelos processos atmosféricos no oceano aberto. Neste contexto, as tempestades possuem forte influência na variabilidade do sedimento praial em diferentes escalas, normalmente causando erosão em toda a extensão de área emersa do sistema praial, desde a face praial até as escarpas e dunas. O sedimento empilhado nesse setor acaba por se espalhar pela face litorânea e costa afora, deslocando o início da zona de espraiamento e até mesmo a profundidade basal das ondas, sendo o tempo de recuperação do sistema relativo tanto à intensidade quanto a duração do evento (Gagliardi, 2013).

Segundo Tessler \& Goya (2005), três grandes sistemas atmosféricos são responsáveis pelo controle do clima de ondas na América do Sul, a saber: a Zona de Convergência Intertropical (ITCZ), responsável pelas ondulações e processos costeiros da região brasileira setentrional; o Anticiclone Tropical do Atlântico Sul (ATAS), centro de alta pressão responsável pelos ventos alíseos; e o Anticiclone Polar Migratório (APM), centros de alta pressão responsável pela passagem de sistemas frontais.

O Anticiclone Tropical Atlântico (ATA) comporta-se de maneira semifixa, apresentando movimento de oscilação de posição norte-sul (entre as latitudes $15^{\circ} \mathrm{N}$ e $5^{\circ} \mathrm{S}$ ), possuindo pressões máximas entre 1020 e $1023 \mathrm{mb}$, bem como temperaturas elevadas, sendo responsável por ventos oriundos de NE com frequência constante ao longo do ano com variação de sua intensidade entre as latitudes $10^{\circ} \mathrm{S}$ e $40^{\circ} \mathrm{S}$ (Monteiro apud Martins, 2000; Goya, 2011).

O Anticiclone Polar Migratório (APM) é formado por acúmulo de ar frio em latitudes subpolares $\left(60^{\circ} \mathrm{S}\right)$, possui altos valores de pressão $(1014-1036 \mathrm{mb})$ e são 
caracterizados por serem sistemas em evolução, buscando o equilíbrio térmico. Deste modo, varia sua posição movendo-se meridionalmente, precedidos por frentes (Goya, 2011; Fonzar, 1994).

Segundo Mendonça \& Danni-Oliveira (2007), denomina-se Frente o encontro de duas massas de ar com características distintas, que assim produz uma zona ou superfície de descontinuidade no interior da atmosfera, caracterizada por um padrão estreito e inclinada, onde elementos climáticos apresentam variação abrupta. As frentes avançam sobre a superfície em forma de arco, sendo a origem um centro de alta pressão e a ponta do arco correspondente a um centro de baixa pressão. As frentes frias no hemisfério sul se deslocam para norte com a embocadura voltada para sul, enquanto que as frentes quentes mostram o padrão inverso. Uma frente fria é caracterizada pelo deslocamento da massa de ar quente pela ação da massa de ar frio, a qual desloca a massa quente tanto por elevação quanto advecção.

Os sistemas frontais são perturbações atmosféricas de grande importância para o clima da região sudeste brasileiro. Sua gênese tem início em um centro de baixa pressão proporcional ao gradiente de temperatura e umidade das massas adjacentes provenientes da ATA e APM. Ao adquirir vorticidade em superfície, ocorre a ciclogênese, gerando os chamados ciclones extratropicais (Nobre et. al. 1986).

Os ciclones extratropicais estão ligados às trocas de calor entre a zona tropical e os polos. São considerados os fenômenos dominantes do clima na escala sinótica em médias e altas latitudes e normalmente estão associados a fortes ventos e chuvas (Lim \& Simmonds, 2007). Estudos têm sido realizados no âmbito tanto da análise de suas características, frequência de ocorrência e relações com modulações climáticas globais, bem como das áreas com maior probabilidade de ciclogênese na América do Sul (Gan \& Rao, 1991; Sinclair, 1994; Simmonds \& Keay, 2000; Solman \& Menéndez, 2001; Pezza \& Ambrizzi, 2003; Hoskins \& Hodges 2005; Reboita, 2008; Mendes et.al., 2009).

Mendes et al. (2009), em estudo utilizando uma longa série de dados de reanálise, desenvolveram uma análise de quantidade de ciclones extratropicais e suas características em uma subdivisão sazonal, encontraram uma região característica para formação de ciclones localizada próxima a costa da Argentina, Uruguai e Sul do Brasil. O período de inverno apresenta o maior período de formação de tais ciclones na região, estando tais resultados de acordo com os apresentados por Gan \& Rao (1991) e Simmonds \& Keay (2000). Além disso, os autores encontram uma disparidade em relação aos ciclones de inverno em relação a características quando comparado com as 
outras estações, sendo a frequência da distância bem distribuída, enquanto que no outono/primavera os ciclones raramente se deslocam distâncias maiores que $3000 \mathrm{~km}$.

Outra área de ciclogênese pode ser encontrada na zona tropical do Atlântico Sul (entre $20^{\circ} \mathrm{S}$ e $35^{\circ} \mathrm{S}$ ), na costa das regiões Sul e Sudeste do Brasil, sendo tal mais ativa durante o verão, estando ligada a sistemas atmosféricos provindos do Pacífico os quais se intensificam por transferência de calor latente entre águas costeiras e a atmosfera (Hoskins \& Hodges, 2005; Reboita, 2008).

Em relação à frequência de ocorrência de ciclones extratropicais na América do Sul, a estação de inverno apresenta maiores valores (305), seguida por outono (302), primavera (268) e verão (207), sendo o mês de maio o com maior frequência, em detrimento do mês de dezembro, com menor atividade de tais ciclones (Gan \& Rao, 1991). Estes sistemas são fortemente condicionados por variáveis climáticas globais, como fenômeno ENSO (El Niño Southern Oscillation) e AAO (Antartic Oscillation), ocorrendo um aumento das ciclogêneses em períodos de fase positiva da ENSO e AAO, este principalmente no inverno (Gan \& Rao, 1991; Mendes et.al., 2009).

Em relação ao clima, a região é caracterizada como Clima tropical úmido sem períodos de seca bem definidos, de acordo com classificação climática de KöppenGeiger (Lepsch et al., 1990; Kottek et al., 2006). O litoral sul paulista é influenciado diretamente pela Zona de Convergência do Atlântico Sul (ZCAS), caracterizada por uma faixa semi-permanente de orientação NW-SE, de nebulosidade e condensação, que separa as regiões de domínio de massa de ar equatoriais e tropicais das massas de ar tropicais e polares (Satyamurti, et. al., 1998). Deste modo, o clima da região é marcado por duas condições distintas associadas a movimentações das massas de ar: ação de ventos alíseos de NE devido a ação da massa de ar Tropical Atlântica e outra sobre efeito da massa de ar polar (Nimer, 1989).

Segundo Sant'Anna Neto (2005), no verão, há o predomínio das correntes de leste, originadas do deslocamento dos ventos alíseos na baixa troposfera pela massa Tropical Atlântica. Tal sistema produz estabilidade, e a medida que adentra para interior da região Sudeste, provoca elevação de temperaturas e diminuição da umidade. De maneira inversa, as correntes de Sul, derivadas da penetração do Anticiclone Polar Migratório, provocam zonas de instabilidade as quais são responsáveis por quase $2 / 3$ da gênese pluvial da região. Tais correntes carregadas de umidade do oceano despejam chuvas de primavera/verão que decrescem de sul para norte, denotando uma distribuição 
desigual da pluviosidade. Ainda, efeitos orográficos derivados da Serra do Mar incrementam chuvas locais e têm forte influência no clima regional.

De acordo com Sousa (2013), através de dados climatológicos de 30 anos disponibilizados pelo Clima Tempo/INMET, a região da Ilha Comprida apresenta precipitação média anual de $1971 \mathrm{~mm} / \mathrm{ano}$, com temperatura média de $22^{\circ} \mathrm{C}$, sendo os meses com maior precipitação e temperatura os meses entre Janeiro e Março, em detrimento do período entre Maio e Agosto que apresentam menores valores médios das variáveis supracitadas. o regime de chuvas em Cananéia, porção sul da Ilha Comprida, é $38 \%$ mais intenso que em Iguape, porção norte da Ilha Comprida, com valores de temperatura variando de $23,1^{\circ} \mathrm{C}$ a $17,7^{\circ} \mathrm{C}$ (GEOBRÁS, 1966).

\subsubsection{Ondas e Marés}

Os padrões ondulatórios gerados pelas diferentes forçantes atmosféricas possuem influência direta na dinâmica costeira. Uma vez que os principais fatores que determinam o desenvolvimento das ondas são a intensidade do vento, sua duração e a pista sobre a qual atua, pode-se dizer que a velocidade de deslocamento da frente fria, o gradiente de pressão a ela associado e seu próprio tamanho são imprescindíveis na determinação do campo de ondas que será formado (Candella, 1997).

Pianca et. al. (2010), em trabalho realizado acerca da climatologia de ondas de água profunda ao longo da costa brasileira a partir de dados de reanálise de modelo numérico operacional global, situou a característica dos padrões ondulatórios para cada setor do país, tanto em tendências gerais quanto sazonais. A autora descreve para a costa sudeste um padrão onde:

- Verão: ondas do quadrante S são predominantes (29.2\%), com alturas significativas entre 1 e 2 metros e período de onda entre 10 e 12 segundos, seguida de ondas de E (27\% de ocorrência);

- Outono: ondulações do quadrante S são predominantes $(47,2 \%)$, com aumento da altura significativa das ondulações, sendo a porção entre 2 e 3 metros tão significativa quando as entre 1 e 2 metros.

- Inverno: ondulações do quadrantes S são dominantes $(38,1 \%)$, com alturas significativas entre 2 e 3 metros e períodos entre 10 e 12 segundos. 
- Primavera: ondulações do quadrante E predominam (27 \%), com altura significativa entre 1 e 2 metros e 2 e 3 metros, com períodos de onda entre 6 e 8 segundos.

$\mathrm{Na}$ costa paulista, a passagem de sistemas frontais definem os padrões ondulatórios e sua variabilidade ao longo do ano, definindo basicamente três situações distintas de ondas que chegam à linha de costa e, consequentemente, de transferência de energia no sistema costeiro (Ponçano et. al., 1999; Araújo et. al., 2003; Rodrigues, 2009; Pianca et. al. 2010):

- Condição pré-frontal: Ventos em torno de $5 \mathrm{~m} / \mathrm{s}$; provenientes inicialmente de NE, girando em sentido anti-horário para NW seguindo o padrão de deslocamento do sistema, seguida de uma queda de pressão e elevação de temperatura. As ondulações geradas nesta situação são provenientes dos quadrantes S e SE, gerando de modo geral tendências de transporte costeiro para NE.

- Condição Frontal: Aumento da pressão atmosférica, seguida de alta precipitação e instabilidade climática, com ventos predominantes de SW-S-SE com velocidades de $5 \mathrm{~m} / \mathrm{s}$, com esparsas rajadas de ventos mais intensas. Neste estágio, ondas do quadrante E são geradas, podendo entretanto a deriva litorânea estar direcionada tanto para NE quanto SW.

- Condição Pós-frontal: Denotada pela passagem total da frente, é caracterizada por queda de temperatura e gradação em sentido anti-horário da direção dos ventos de SW para NE, conforme o sistema se afasta, de modo a se aproximar as condições anteriores de estabilidade. Neste estágio, ondulações predominantes de NE são encontradas, gerando transporte longitudinal costeiro direcionada para SW.

De modo geral, o Anticiclone Tropical Atlântico (ATA), o qual gera ventos do oceano para o continente durante todo o ano e ondulações dos quadrantes NE-E, é menos efetivo no transporte longitudinal de material arenoso em sistemas praiais na costa paulista quando comparada com ondulações geradas pelo Anticiclone Polar Migratório (APM), as quais são mais efetivas e energéticas, associadas às situações de pré-frontal, frontal e pós-frontal (Ponçano et. al., 1999; Santos, 2005). Na Ilha Comprida, os ventos locais não geram interferência sobre as ondulações geradas pelos centros de geração oceânicos (GEOBRÁS, 1966). 
Em relação à maré, esta pode ser um importante fator para a dinâmica costeira de praias, sendo que variações entre marés de sizígia e quadratura modulam processos na zona de surfe, alterando a posição e tamanho da zona de surfe e assim, tendo consequências na estrutura morfológica praial (Wright et. al., 1987).

A região do litoral sul paulista é condicionada por uma maré com característica de micromaré (inferiores a 2 metros), com variações médias de 1,2 metros na sizígia e 0,25 metros na quadratura, e com caráter predominantemente semi-diurno (Mesquita \& Harari, 1983; Harari \& Camargo, 1994). 


\section{MATERIAL E MÉTODOS}

Para o presente estudo, diferentes ferramentas e abordagens foram escolhidas de modo a abrangerem as diferentes escalas de análise propostas. Para a escala sazonal, dados de campo em conjunto com modelagem numérica foram utilizados, e para escala interanual, dados de modelagem tanto global operacional quanto para processos costeiros.

Deste modo, considerando a escala sazonal, foram escolhidos seis trechos para análise das tendências gerais de transporte ao longo da ilha e cinco setores distintos da praia para os levantamentos morfo-sedimentares (Figura 4.1). Os cinco trechos de praia possuem extensão aproximada entre 300-500 metros e comprimento transversal que vai da crista do primeiro berma, no pós-praia, até a linha da água, na antepraia, e foram escolhidos por apresentarem diferenças baseadas em estudos pretéritos realizados na região. Estes trechos foram monitorados por um ano com uma periodicidade amostral de aproximadamente três meses, em relação a suas características topográficas e sedimentares a partir de levantamentos tridimensionais e coleta de sedimentos nos diferentes compartimentos. Optou-se por uma diferente subdivisão para análise das tendências gerais de transporte, provindas da modelagem numérica, tendo em vista a não regularidade espacial dos cinco setores. Cada trecho de praia é nomeado por Caminhamento, sendo o primeiro referente ao trecho mais ao norte e o último ao trecho mais ao sul, com a numeração semelhante a utilizada para análise hidrodinâmica.

Tabela 4.1: Nomenclatura utilizada para representar cada levantamento, bem como as características gerais encontradas na data de cada coleta.

\begin{tabular}{|c|c|c|c|c|}
\hline \multirow[t]{2}{*}{ Campo } & \multirow[t]{2}{*}{ Data } & \multicolumn{2}{|c|}{ Maré } & Lua \\
\hline & & Mínima & Máxima & \\
\hline A & $13-17 / 05 / 2013$ & 0,2 & 1,4 & Nova-Crescente \\
\hline B & $13-15 / 08 / 2013$ & 0,5 & 1,1 & Crescente \\
\hline $\mathbf{C}$ & $05-07 / 11 / 2013$ & 0,2 & 1,5 & Nova-Crescente \\
\hline D & $11-12 / 02 / 2014$ & 0,2 & 1,5 & Cheia \\
\hline $\mathbf{E}$ & $13-15 / 05 / 2014$ & 0 & 1,5 & Cheia \\
\hline
\end{tabular}




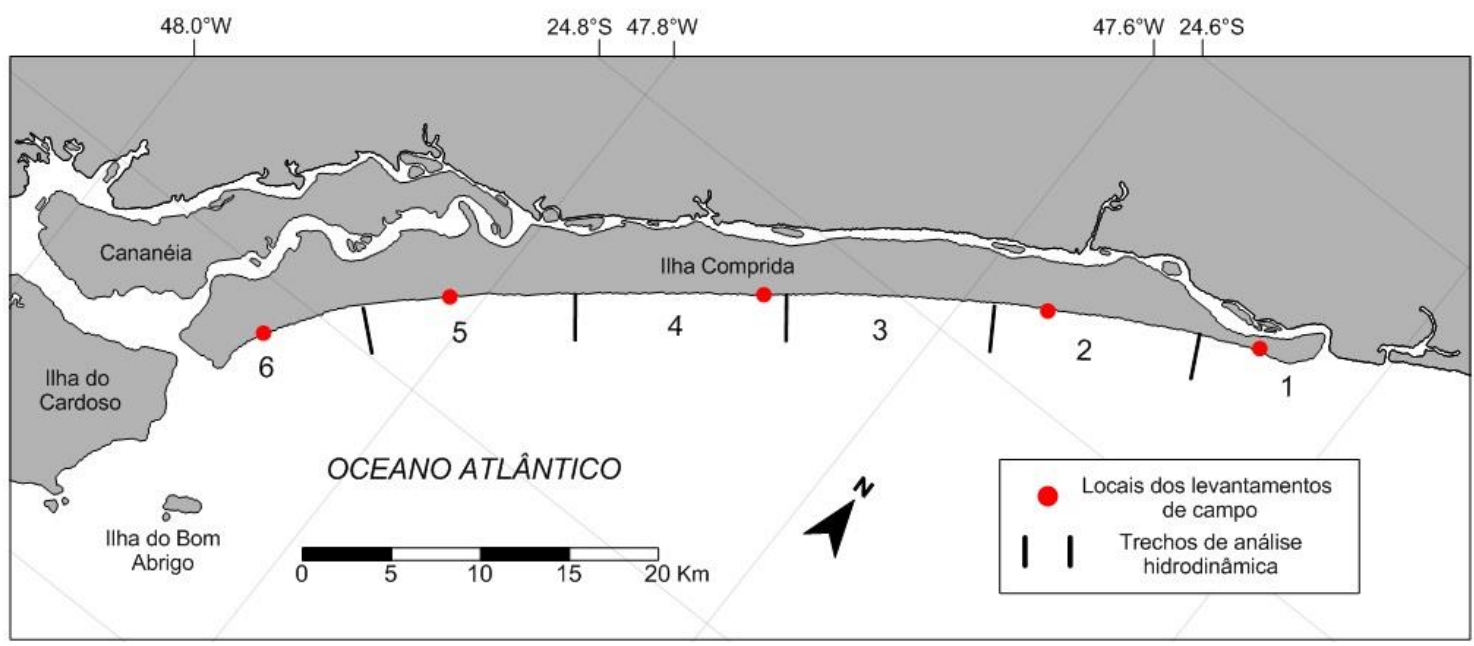

Figura 4.1: Localização aproximada dos cinco setores de levantamentos de campo (círculos vermelhos), bem como a subdivisão adotada para análise das propriedades hidrodinâmicas.

\subsection{Morfologia}

\subsubsection{Levantamentos de campo}

Os levantamentos topográficos foram realizados a partir da utilização do Sistema de Posicionamento Global Diferencial (DGPS). O método consiste na utilização simultânea de dois ou mais receptores GPS, sendo um utilizado como ponto base de referência coletando dados em um ponto conhecido, enquanto que outro receptor coleta os dados dos locais desconhecidos. Partindo do pressuposto que o erro dos receptores é semelhante em uma área limitada, é possível calcular a distância entre os receptores e os satélites, comparando-as com a pseudo-distância medida na estação utilizada como base. Assim, as diferenças são transmitidas e utilizadas nas correções do receptor móvel, refinando o cálculo de sua posição, podendo fornecer uma acurácia centimétrica aos dados após pós-processamento. (Monico, 2008).

No presente estudo foram utilizados receptores GPS de precisão modelos R4 e 5700 com antena do tipo Zephyr, ambos da marca Trimble. O 5700 foi configurado para funcionar como base receptora e programado para coletar pontos a cada um segundo com estilo de levantamento estático. A duração média de coleta de dados da base foi de, pelo menos, sete horas para cada levantamento. O aparelho R4 foi utilizado como receptor móvel, sendo configurado para coleta de dados a cada um segundo em estilo de levantamento PP cinemático. O método de coleta e análise desses dados foi Posicionamento Relativo Cinemático Pós- Processado, descrito em detalhe por Monico (2008) e Sousa (2013) (Figura 4.2). 
O modo de coleta dos dados topográficos foi na forma da soma de perfis transversais, espaçados entre 30 e 50 metros, e longitudinais, sendo um localizado no topo da duna, outro na base da duna, um na face praial média e outro na face praial inferior (Figura 4.3). Todos os levantamentos compreenderam como limite superior a topo da duna frontal e como limite inferior a menor isóbata de profundidade da face de praia/antepraia possível de se alcançar tendo em vista as condições do oceano e da maré no momento do levantamento.

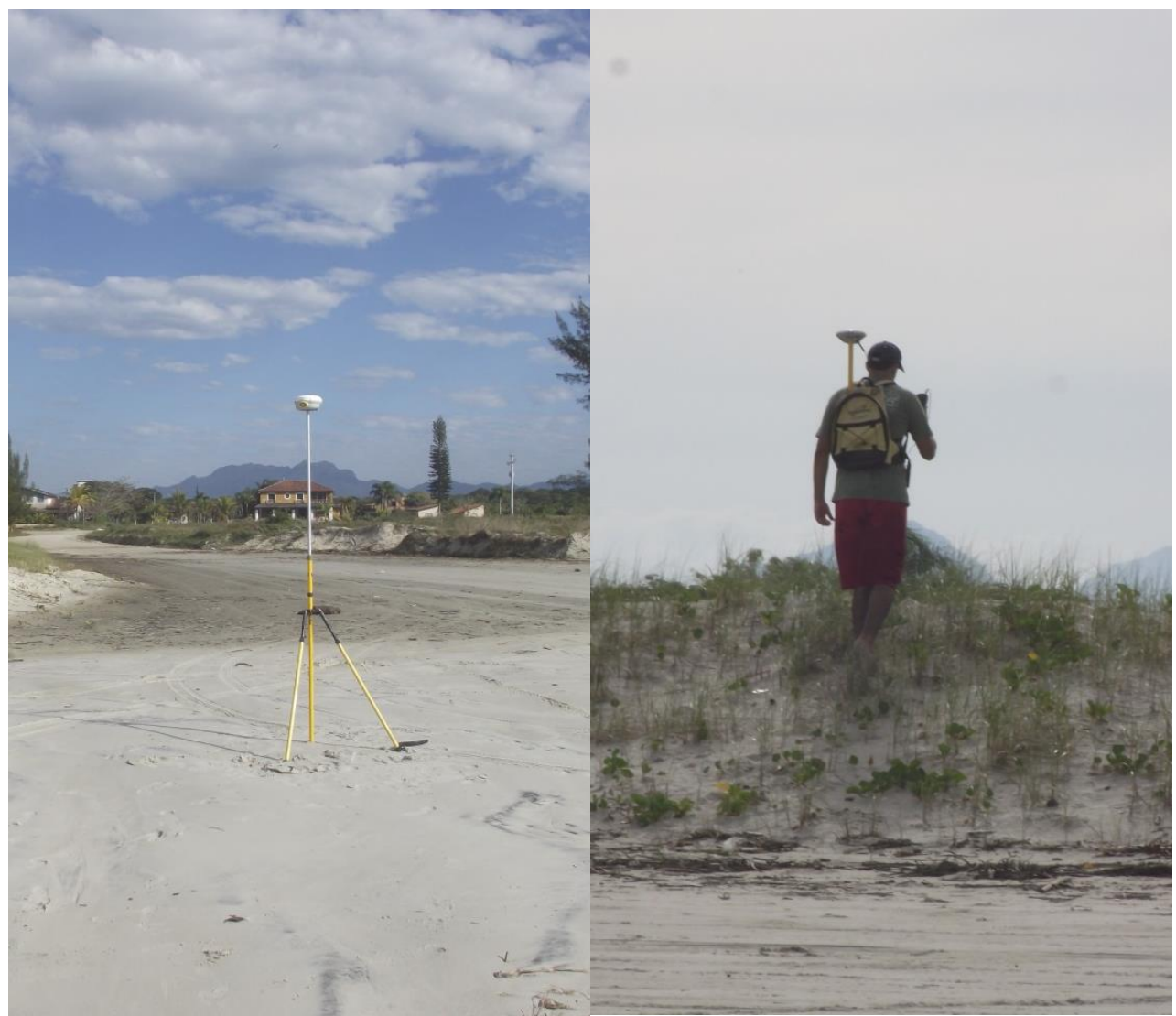

Figura 4.2: Aparelho GPS de precisão utilizado como base móvel, calibrando sua posição para o início do levantamento (esquerda). Exemplo fotográfico do método adotado para o caminhamento (direita). 


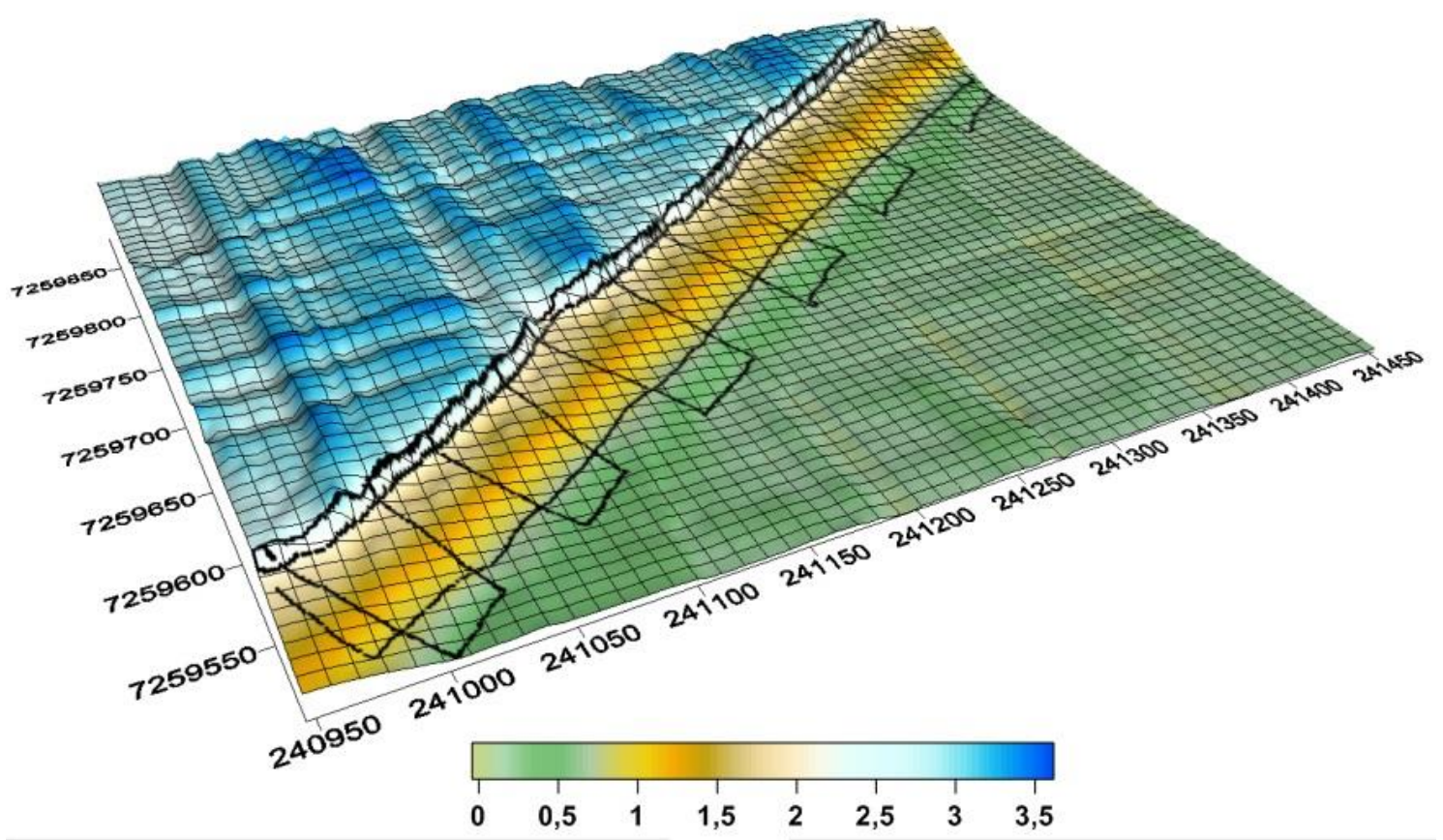

Figura 4.3: Exemplo de distribuição espacial dos transectos longitudinais e transversais de coleta de dados altimétricos, com o uso do DGPS, evidenciando a tentativa distribuição regular da malha. Malha utilizada como exemplo, antes da limitação horizontal. Escala em metros e representação em UTM.

\subsubsection{Processamento dos dados}

Os dados obtidos foram tratados no software do equipamento, Trimble Geometric Office versão 1.6, sendo os arquivos de saída planilhas com dados de posição e altimetria. Primeiramente, os pontos utilizados como bases foram triangulados, processados e ajustados através da Rede Brasileira de Monitoramento Contínuo dos Sistemas GNSS (RBMC), disponíveis no sítio eletrônico do Instituto Brasileiro de Geografia e Estatística (IBGE), sendo utilizados dados das estações de Cananéia (NEIA) e Curitiba (UFPR). Tal procedimento é necessário para corrigir os dados coletados pelas bases fixas, de modo a maximizar a capacidade de acurácia das medições e minimizar a propagação de erro nas correções dos receptores móveis. Após a correção das bases fixas, estas foram utilizadas para correção dos receptores móveis, de modo a ter como arquivo de saída as posições geográficas de cada ponto e a altimetria em relação ao elipsoide matemático. Nas configurações do projeto para o processamento dos dados de cada campo, a qualidade do levantamento foi limitada a uma variação máxima de $0,10 \mathrm{~m}$.

Segundo Torge (2001), o elipsoide é definido como uma figura matemática que representa a terra na forma de uma esfera achatada nos polos e considera que a Terra 
possui a superfície lisa. Sendo o geóide um modelo irregular do elipsoide e os valores de altimetria referenciados para o elipsoide matemático, uma correção foi realizada de modo a encontrar a altura ortométrica para cada levantamento, utilizando-se da seguinte equação:

$$
H=h-N
$$

onde $\mathrm{H}$ é a altura ortométrica, h é a altura elipsoidal e $\mathrm{N}$ é o valor da ondulação geoidal (Figura 4.4). Para o presente estudo, o modelo geoidal adotado foi o SIRGAS 2000.

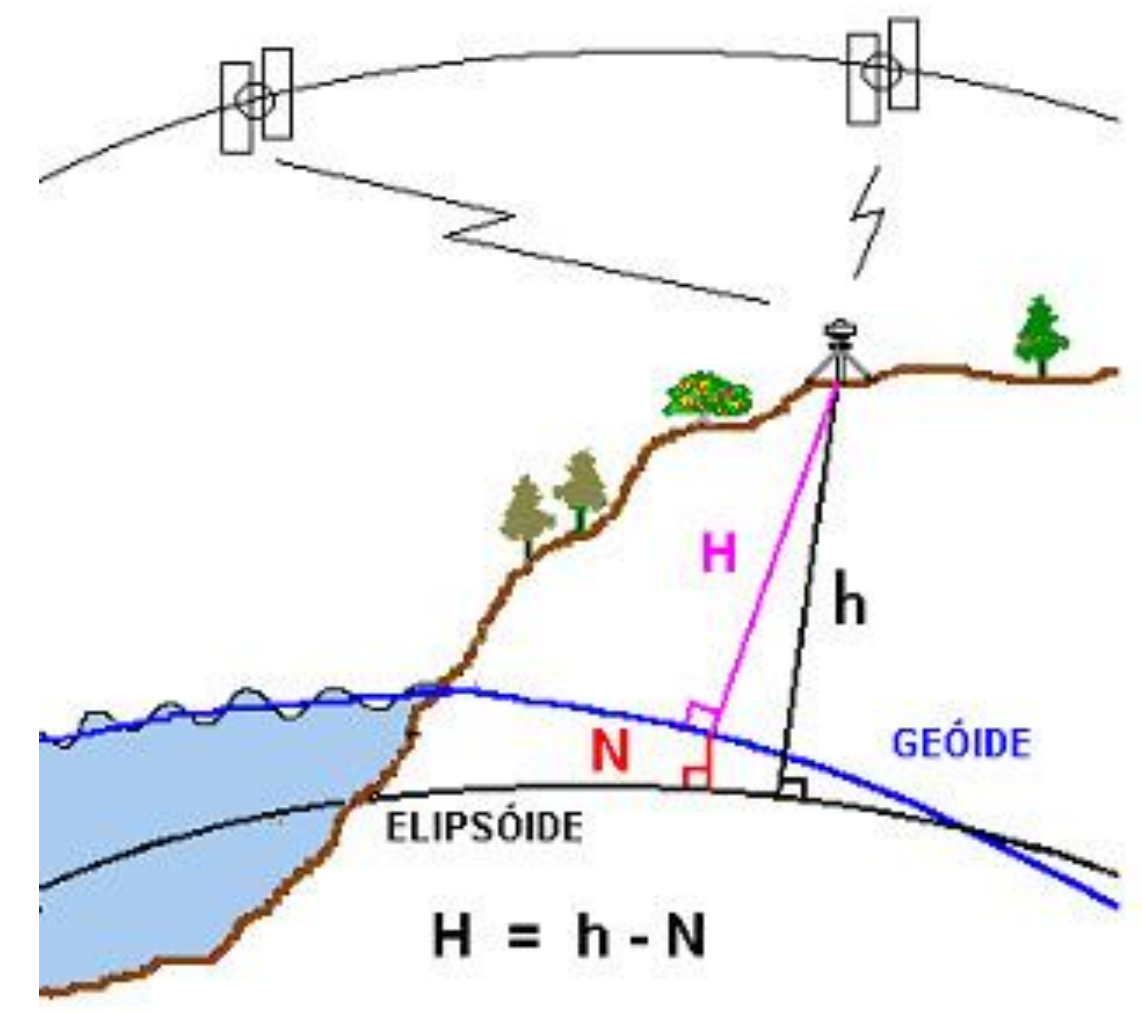

Figura 4.4: Cálculo da altura ortométrica e esboço do elipsoide e geoide. Fonte: IBGE

A partir destes dados, foi estimado o volume de cada trecho, bem como mapas de contorno e de diferença altimétrica. Para tanto, os dados de cada caminhamento foram interpolados em uma malha regular, de modo a ser possível realizar a parametrização de uma superfície, a partir da qual são elaborados os cálculos e mapas 
propostos. O método de interpolação utilizado foi a krigagem, utilizando-se de um variograma linear.

O volume foi calculado a partir da integração entre uma superfície $f(\mathrm{x}, \mathrm{y})$, parametrizada a partir da malha interpolada, e uma superfície plana Z, com valor inferior ao menor valor altimétrico encontrado em todos os levantamentos. No caso, foi utilizada $\mathrm{Z}$ igual a -1 . O software Surfer 11 aproxima a integral e calcula o volume utilizando três métodos distintos, a saber: Regra trapezoidal; Regra de Simpson e Regra de Simpson 3/8. A diferença entre as três regras mede a acurácia dos cálculos de volume e consequentemente a qualidade da malha calculada. Caso os valores encontrados pelas três parametrizações sejam próximos, considera-se a malha satisfatória e o volume líquido utilizado torna-se a média entre os três métodos.

Para comparação entre os volumes dos levantamentos, tanto do mesmo setor, quanto de diferentes setores, foi utilizada uma máscara padrão para todas as malhas. Esta máscara limita horizontalmente as malhas interpoladas, fixando uma área para comparação. Para tanto, a máscara será construída a partir da malha com menor resolução horizontal, a qual foi delimitada pelos limites espaciais dos dados coletados, ou seja, o levantamento com menor alcance horizontal. Tendo em vista a difícil delimitação da largura de cada setor, devido variações no azimute e feições presentes na praia, foi realizada uma normalização do valor volumétrico em relação à largura total da máscara utilizada. Deste modo, é utilizado valor por unidade de comprimento, o qual possibilita a comparação entre os diferentes setores.

\subsection{Sedimentologia}

Para a caracterização sedimentológica de cada trecho, foram realizadas coletas nos três setores praiais principais, ou seja, pós-praia, face praial e antepraia segundo terminologia proposta por Tessler \& Mahiques (2000). As análises granulométricas foram realizadas no Laboratório de Sedimentologia do Instituto Oceanográfico da Universidade de São Paulo, utilizando o analisador a laser Malvern 2000. O equipamento utiliza o conceito de difração para estimativas do tamanho das partículas, medindo a intensidade da luz dispersada a partir da aplicação de um feixe de luz em uma quantidade específica de sedimento. As amostras foram tratadas, sendo retirada todo $\mathrm{O} \mathrm{CaO}_{3}$ por meio de adição de solução de $\mathrm{HCl} 10 \%$, sendo apenas após secagem introduzidas no equipamento para reconhecimento das frações granulométricas. Os 
dados obtidos foram organizados em intervalos de $1 / 4$ de $\varphi$, onde $\varphi=-\log _{2} d$, sendo os parâmetros estatísticos determinados segundo Folk \& Ward (1957).

\subsection{Dados Meteorológicos e Oceanográficos}

Para a avaliação dos perfis em relação às forçantes oceanográficas atuantes nos períodos, um levantamento do número dos sistemas frontais que atingiram a costa brasileira durante o intervalo de tempo das amostragens foi realizado, a partir de dados disponibilizados pelo Centro de Previsão de tempo e estudos climáticos do Instituto Nacional de Pesquisas Espaciais (CPTEC-INPE). Estes dados são disponibilizados no site do instituto, por meio de cartas de síntese sinótica. Tal carta é disponibilizada mensalmente fornecendo o acompanhamento dos principais sistemas meteorológicos que atuaram na América do Sul á norte do paralelo $40^{\circ} \mathrm{S}$, além de uma análise das anomalias de precipitação e temperatura atmosférica no período.

Em relação aos dados de onda, foram utilizados dados do modelo global WAVEWATCH III, desenvolvido pelo NCEP (National Center for Environmental Prediction), da NOAA (National Oceanic and Atmospheric Administration). O modelo utiliza a equação do balanço da densidade de ação espectral para o espectro direcional da onda, sendo incluído o crescimento, refração e decaimento para cada período específico. Maiores informações podem ser encontrados em Tolman (1999).

Considerando a escala interanual, foram extraídos dados referentes a uma simulação de 30 anos (1979-2009), realizada a partir de forçantes de vento do novo CFSRR (NCEP Climate Forecast System Reanalysis Reforecast) com resolução espacial de $1 / 2^{\circ}$, os quais foram utilizados para as análises de grande escala temporal. Em relação à escala sazonal de análise, dados mensais referentes aos períodos anteriores aos campos (entre Fevereiro/2013 e Maio/2014) do mesmo modelo foram extraídos e utilizados para as analises e estimativas propostas. Ambos os dados foram extraídos das coordenadas geográficas $26^{\circ} \mathrm{S}$ e $45^{\circ} \mathrm{W}$, de modo a estabelecer relações com os resultados de Pianca et. al. (2010).

Tais dados foram tratados estatisticamente, sendo considerados apenas os dados situados no intervalo $-3 \sigma \leq \bar{X} \leq 3 \sigma$, onde $\sigma$ é o desvio padrão mensal e $\bar{X}$ é a média dos dados mensais. Foram utilizados apenas os dados cuja direção esteve entre os extremos $22,5^{\circ}$ e $247,5^{\circ}$, arco tal que abrange as ondas incidentes na área de estudo. Tais dados foram analisados em sua forma total, bem como a partir de uma subdivisão 
sazonal. Para sumarizar os dados a serem introduzidos no modelo, de modo a manter a representatividade, foi proposta a separação de acordo com sua porcentagem de ocorrência considerando a relação Hs e Dir (acima de 5\%). Os períodos de onda utilizados foram os mais frequentes em relação a cada altura de onda.

\subsection{Modelagem numérica}

Tendo em vista os processos de transformação de ondas ao chegarem próximo à costa, foi aplicado o modelo numérico MIKE 21 SW (Spectral Wave model desenvolvido pela DHI Water and Environment), de modo a considerar os processos de refração, reflexão e empinamento. Utiliza-se da derivação das equações básicas do modelo a partir da equação de conservação da densidade da agitação da onda espectral, baseado nas aproximações descritas por Holthuijsen et. al. (1989). Os parâmetros de onda utilizados foram: altura significativa (Hs), período de pico $(\mathrm{Tp})$, a direção $\left({ }^{\circ}\right)$, e o desvio padrão direcional (DSD).

A linha de costa utilizada para a modelagem foi obtida através da digitalização de imagens de satélite georeferenciadas, enquanto que a batimetria foi baseada em dados extraídos do modelo global ETOPO1, desenvolvido pela NOAA, e cartas náuticas. A malha utilizada foi elaborada de modo que sua densidade aumentasse gradualmente em direção à área de estudo, com detalhamento de cerca de $1 \mathrm{~km}$ nas proximidades da costa. As bordas abertas, onde foram introduzidos os dados de entrada, estavam situadas em regiões fora da plataforma continental, enquanto que a área de estudo foi localizada a aproximadamente $100 \mathrm{~km}$ dos limites laterais da linha de costa, para evitar efeitos controversos pela proximidade das bordas. Ainda, as bordas transversais a linha de costa foram subdivididas em duas porções, sendo a parte mais próxima à costa considerada no modelo como lateral boundary, condição a qual é sugerida pelo software para bordas essencialmente lineares, cujos contornos batimétricos estejam perpendiculares à mesma (Figura 4.5).

As ondas mais frequentes para cada subdivisão temporal, separados a partir dos dados referentes ao modelo global, foram introduzidos nas bordas abertas e a simulação foi processada, utilizando das configurações padrão do modelo. Foi utilizada a formulação espectral integral, bem como uma solução quase-estacionária, sendo processada a partir no método Newton-Raphson de iteração, com um número máximo 
de iterações fixado em 500. Não foram introduzidas variações relativas ao nível do mar, correntes e ventos como condições de contorno, devido às escalas a serem abordadas pela modelagem. A condição de quebra de onda foi introduzida na forma de Gamma constante no valor de 0,8 , enquanto que a fricção com o fundo foi introduzida a partir do modelo de rugosidade de Nikuradse, também na forma constante (0,04 metros). As condições iniciais foram baseadas nas formulações de espectro empíricas, considerando a expressão de crescimento JONSWAP.

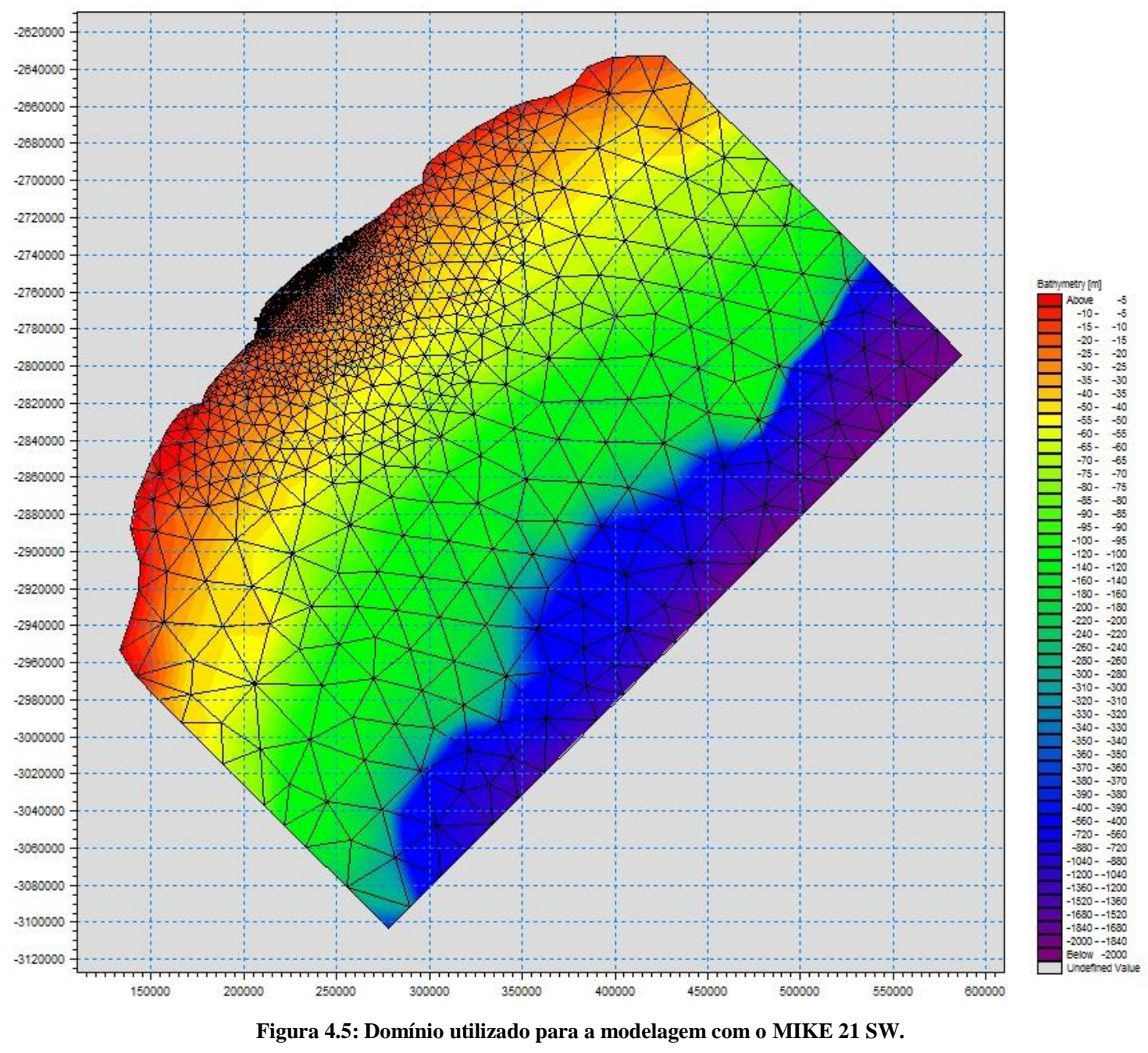

\subsection{Experimentos numéricos}

A partir dos resultados obtidos na modelagem, foram extraídos dados referentes à altura significativa, período e direção das ondas em pontos específicos espaçados regularmente ao longo da costa, na isóbata aproximada de 5 metros. Com tais dados, duas estimativas foram realizadas, a saber: cálculos da deriva potencial e força de onda. 
A estimativa da deriva litorânea potencial é baseada em método desenvolvido por Longuet-Higgins (1970) e Komar (1998), a qual considera a altura de onda e seu ângulo de incidência, fornecendo quantificações relativas entre os diferentes segmentos da costa, bem como estimativas adequadas em uma análise de larga escala, visto que não considera ruídos incorporados por variáveis de alta frequência presentes em outros métodos (Bittencourt et al., 2002, 2005). Ela pode ser definida pela equação:

$$
x=H^{2} \sin \alpha \cos \alpha
$$

onde $\alpha$ é o ângulo de incidência de onda ortogonal a linha de costa, $H$ é a altura de onda próxima a costa e $x$ é a intensidade adimensional do transporte longitudinal. Tal método foi aplicado com sucesso por diversos autores (Siegle \& Asp, 2007; Bittencourt, 2000; 2002; 2003; 2005; Cassiano \& Siegle, 2010; Sousa, 2013), sendo considerado adequado para a abordagem proposta.

A força de onda, denotada em $\mathrm{W} / \mathrm{m}$, é um parâmetro que une o período de onda e a sua altura, podendo estar correlacionado com variações de volume e estágios praiais (Short, 1978). De acordo com a teoria linear de onda exposta em Holthuijsen (2007), o fluxo de energia de onda é dado pelo produto de sua energia por unidade de área com a velocidade de grupo. Deste modo, podemos estimar o seu valor para ondas em águas profundas a partir da equação:

$$
P=\frac{\rho g^{2} H^{2} T}{32 \pi}
$$

onde $\rho$ é a densidade da água $\left(1027 \mathrm{~kg} / \mathrm{m}^{3}\right), g$ é a aceleração da gravidade $\left(9,8 \mathrm{~m} / \mathrm{s}^{2}\right), H$ é a altura significativa da onda, em metros, e $T$ é o período em segundos. No presente estudo, a força de onda será utilizada para verificação de sua variação espaço-temporal e comparação de seus valores com os resultados obtidos entre campos. 


\section{RESULTADOS}

Os resultados serão apresentados referentes às suas escalas. Primeiramente, serão expostos os dados referentes à escala interanual, onde é incorporado o clima de ondas, obtido a partir da série de 30 anos do modelo global WAVEWATCH III, bem como as estimas de deriva potencial e força de onda, para uma análise de larga escala. Consequentemente, serão expostos os dados referentes à escala sazonal, onde serão expostos os dados dos levantamentos de campo e os resultados dos modelos de onda confeccionados para os períodos entre os campos.

\subsection{Escala Interanual}

\subsubsection{Clima de ondas}

Ondas provindas dos quadrantes S, ENE e SSW foram as mais frequentes ao longo dos anos de análise, representando conjuntamente cerca de $60 \%$ das ondulações. A altura mais frequente foi de 1,5 metros, e período de 8 segundos. Histogramas direcionais mostram a frequência de onda e seus parâmetros referentes a cada quadrante (Figura 5.1). No âmbito de reconhecer o tipo de onda mais frequente, um gráfico de dispersão entre a altura e o período foi realizado, com linhas de contorno representando a frequência relativa de cada ondulação (Figura 5.2). As isolinhas estão espaçadas em $1 \%$ de frequência, com o centro representando cerca de $8 \%$ das ondulações e os extremos $1 \%$. A maior onda de toda série teve 6,76 metros de altura significativa, com período de 13,01 segundos e direção de SSW.
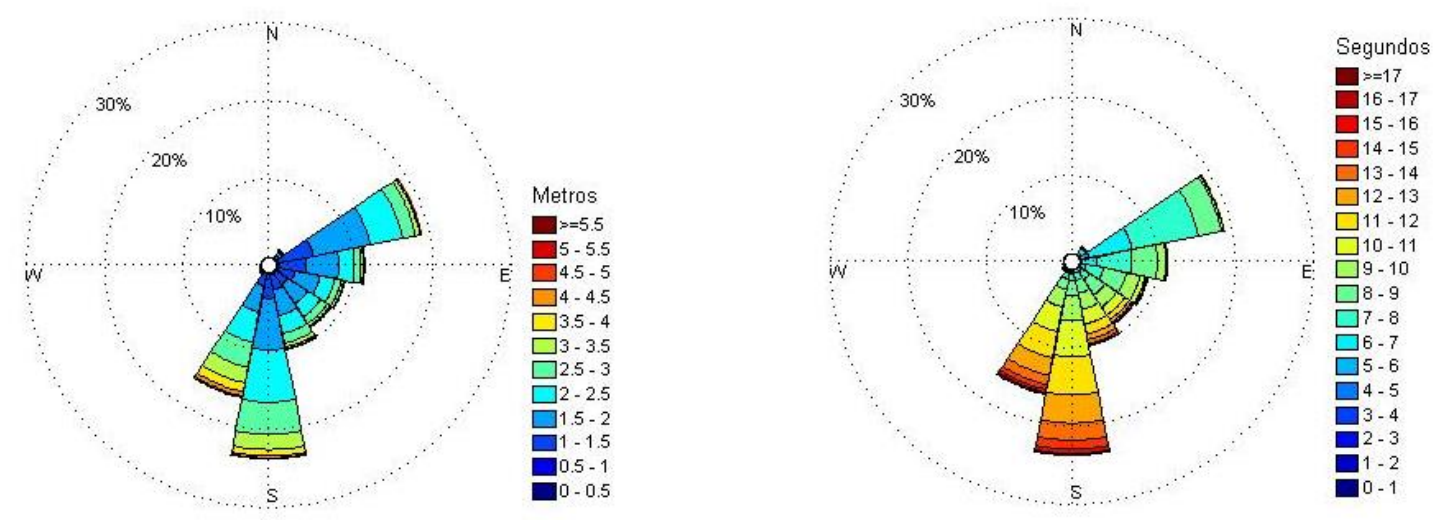


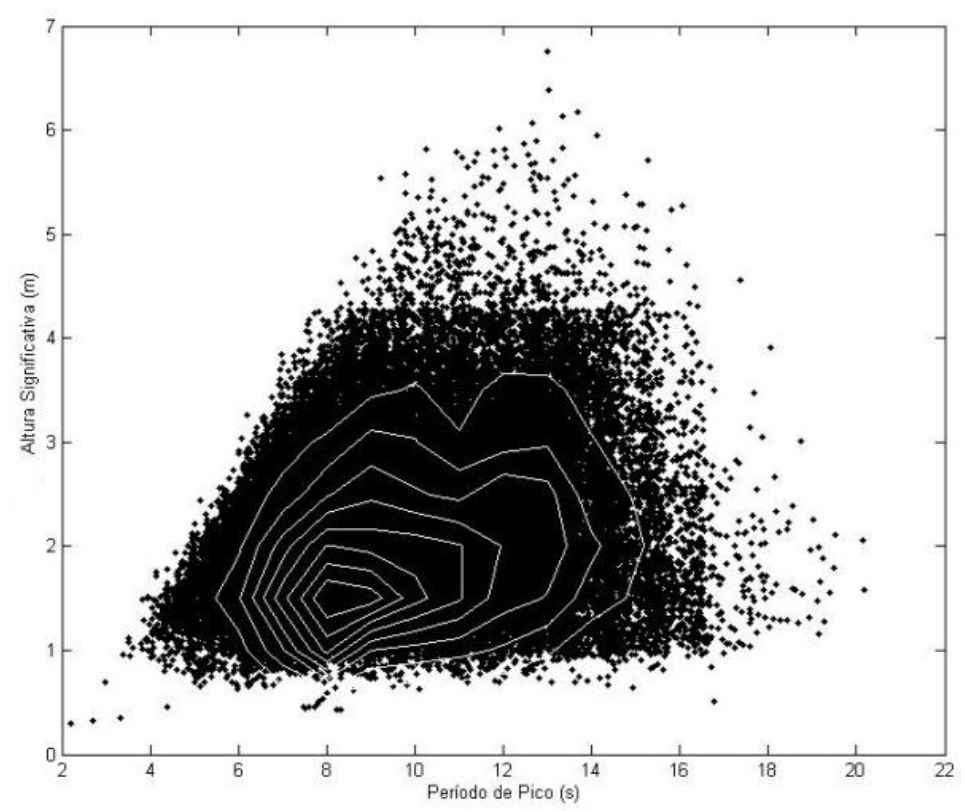

Figura 5.2: Gráfico de dispersão entre a altura significativa e o período de pico, considerando toda série de dados, com contornos referentes à porcentagem de ocorrência (centro com $8 \%$ e extremos com $1 \%$ ).

Os quadrantes predominantes sofreram alterações ao analisar sazonalmente a série temporal, (Figura 5.3). Para os meses de verão, há um predomínio de ondulações provindas do quadrante ENE, com 28,53\% das ocorrências, seguida por ondas do quadrante $\mathrm{S}$ com $17,77 \%$. Uma mudança é reconhecida para os meses de outono, com a mudança do quadrante principal para $S$, representando $28,56 \%$ das ocorrências, seguida pelo quadrante SSE, com 19,14\%. Para os meses de inverno, o padrão é similar ao de outono, com o quadrante preferencial de ondas sem o quadrante S e SSE, com 27,36\% e $21,37 \%$, respectivamente. Uma mudança de quadrante preferencial é reconhecida no período de primavera, com predomínio de ondas de ENE, com 22,86\% de ocorrência e $\mathrm{S}$, com $21,04 \%$. Os gráficos de dispersão também mostram uma variação em relação à onda mais frequente, com ondulações em torno de $1,5 \mathrm{~m}$ de altura significativa e 8 segundos de período para o verão, seguido de um aumento no período mais frequente entre 8-10 segundos e uma manutenção da altura de 1,5 metros nos períodos de outono. Para o inverno, reconhecem-se dois focos de alta frequência, um com ondas entre 8-9 segundos de período e altura aproximada em 1,5 metros; e outro foco com em ondas com altura de 2 metros e período entre 10 -11 segundos. Para primavera, ondas com altura entre 1,5-2 metros e período entre 8-9 segundos predominam (Figura 5.4). As maiores ondas para cada período foram: 5,59 metros, com período de 12.7 segundos para o verão; 6.76 metros, com período de 13.01 segundos para o outono; 6.39 metros, 
com período de 13.03 segundos para o inverno; e 6.02 metros, com período de 11.92 segundos para a primavera. Todas estas ondas tiveram direção de SSW, com exceção da ondulação referente ao período de primavera, a qual apresentou quadrante de $\mathrm{S}$. 


\section{VERÃO}
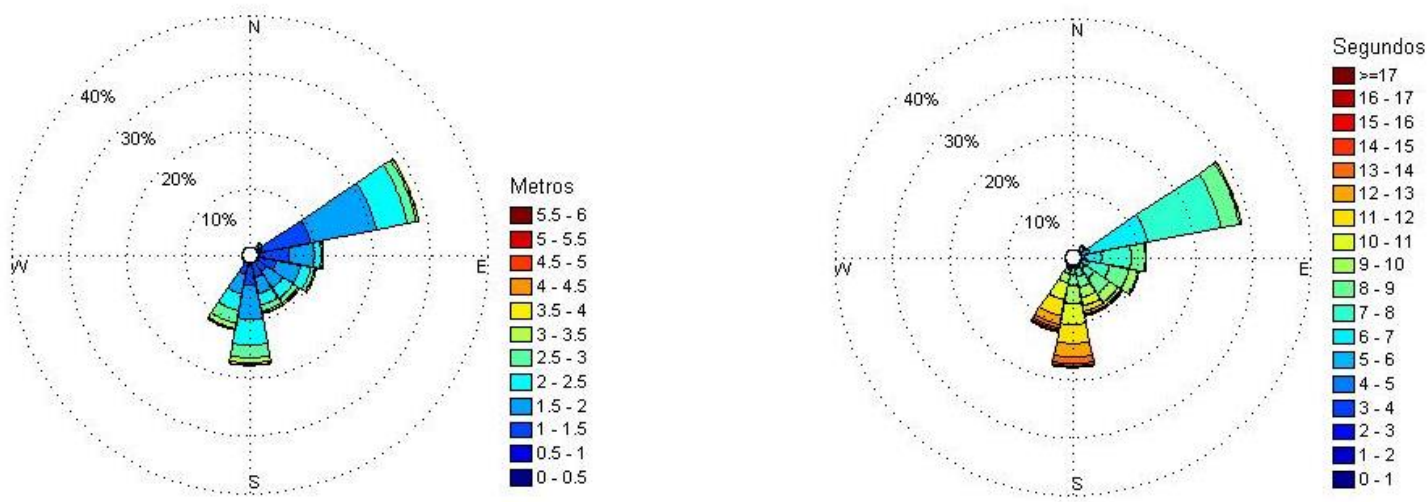

\section{OUTONO}
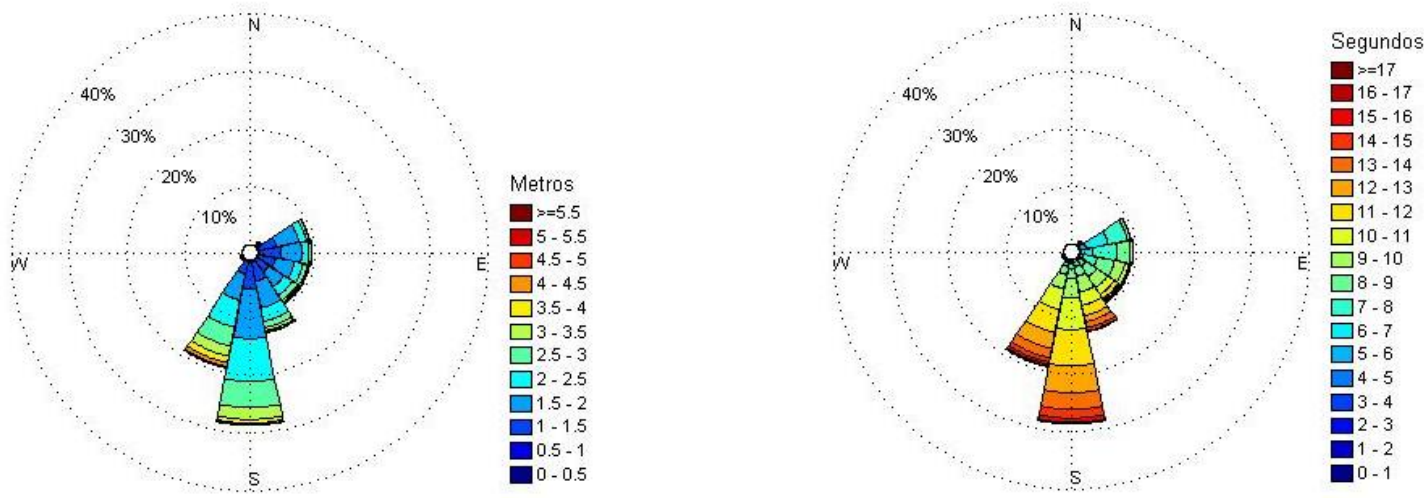

\section{INVERNO}
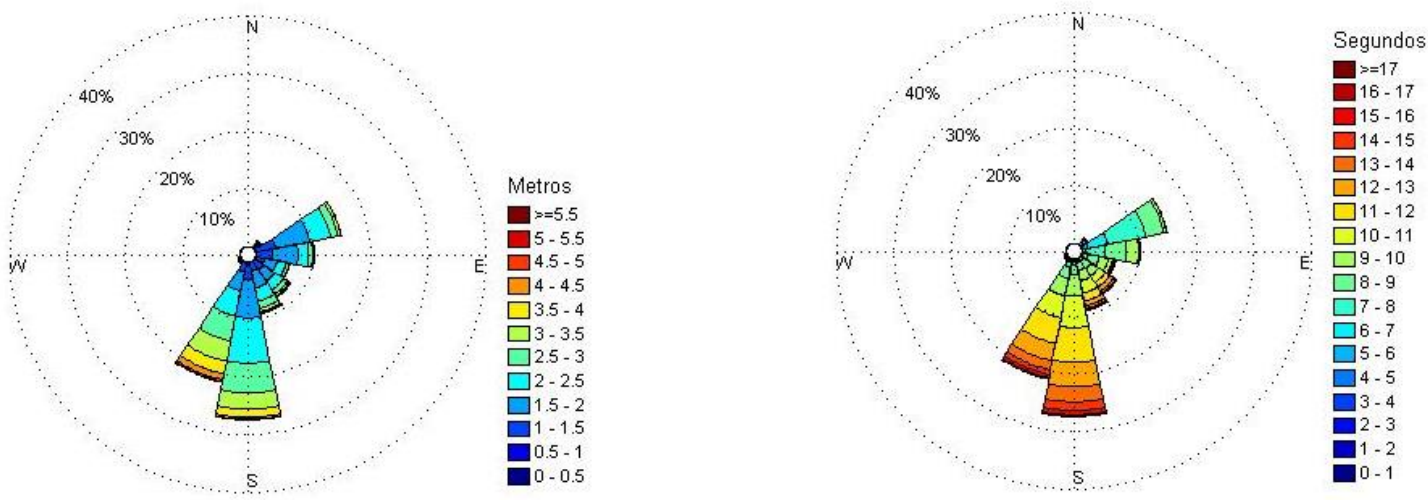

PRIMAVERA
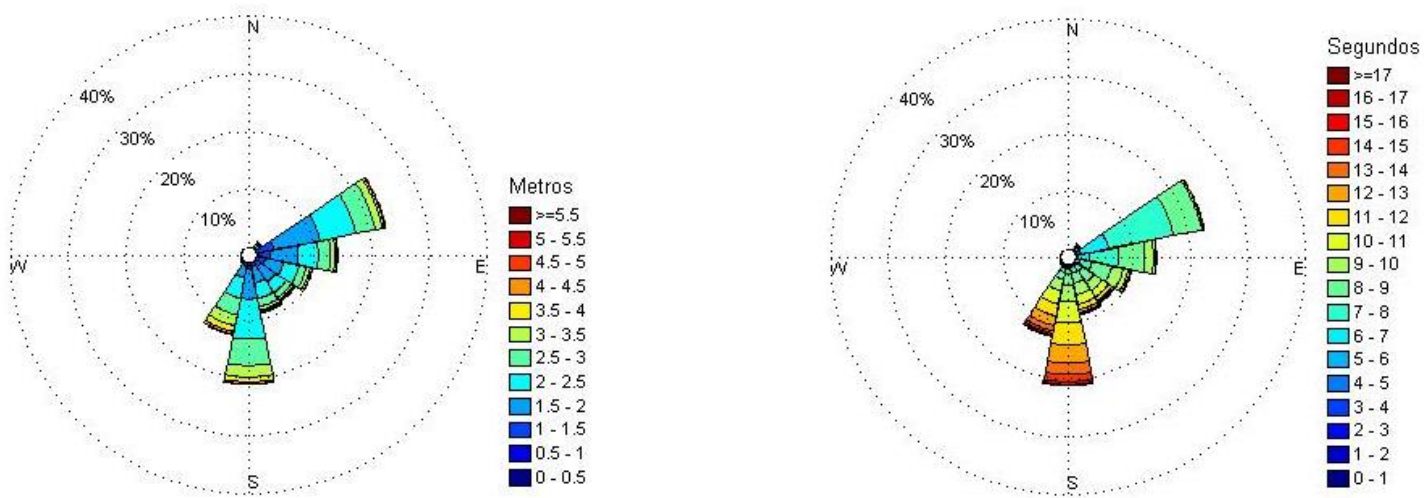

Figura 5.3: Histogramas direcionais de onda para cada estação do ano. Esquerda: Altura Significativa (m); Direita: Período de pico (s). 

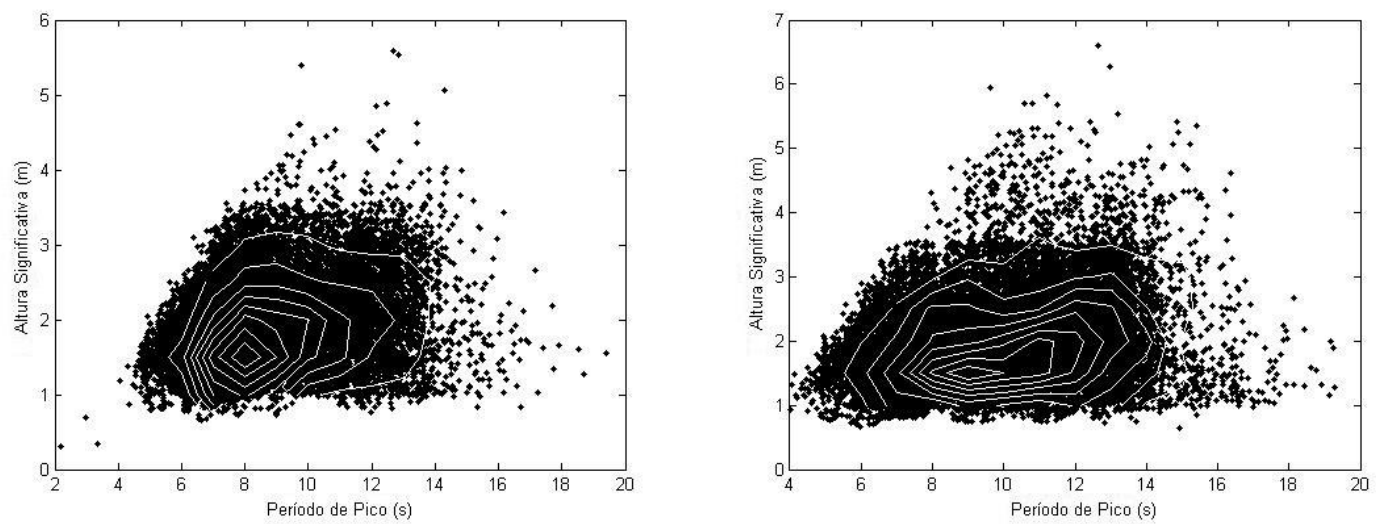

INVERNO - PRIMAVERA
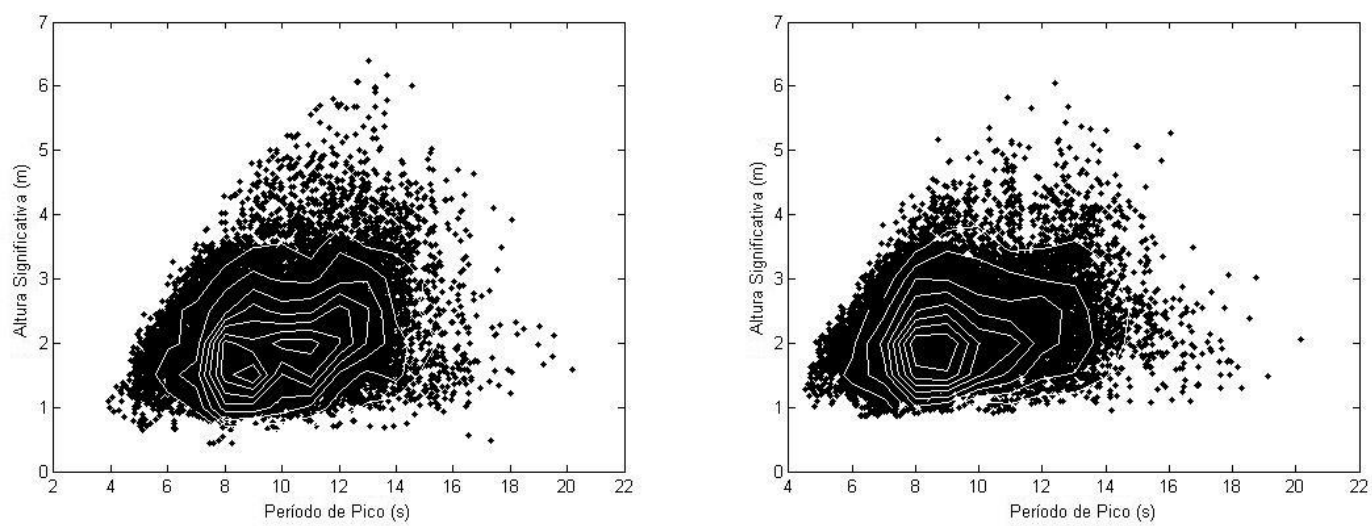

Figura 5.4: Gráfico de dispersão entre a altura significativa e o período de pico, considerando as diferentes estações do ano, com contornos referentes à porcentagem de ocorrência (centro com $8 \%$ e extremos com 1\%).

Pianca et. al. (2010) estudaram o clima de ondas para o Atlântico Sul ao longo da costa brasileira, reconhecendo padrões para cada setor da costa, incluindo a costa sudeste brasileira. Os autores utilizaram uma menor série temporal (11 anos), e uma versão mais antiga do modelo WAVEWATCH III (versão 2.22). De modo geral, foi possível reconhecer algumas diferenças em relação aos padrões estatísticos encontrados pelos autores e o presente trabalho (Tabela 5.1).

Em relação à altura significativa, os valores máximos se mostraram maiores no presente trabalho, principalmente nos meses menos energéticos, onde as diferenças alcançaram 1,6 metros no verão e 1,5 metros na primavera. Durante os períodos mais energéticos, a maior diferença girou em torno de 0,5 metros acima. A diferença entre os valores mínimos são negativas no verão $(-0,4)$ e inverno $(-0,1)$, e positivas no outono $(0,1)$ e primavera $(0,3)$, significando que os valores mínimos são menores no presente estudo quando comparados com os resultados do trabalho anterior durante o verão e inverno. Embora um aumento em todos os períodos tenha sido reconhecido, uma 
manutenção nos valores médios pode ser verificada nos meses energéticos com a redução de 0,2 no desvio padrão para o outono. Em relação ao período de pico, valores mínimos e máximos são maiores no presente estudo assim como a variação máxima, a qual alcança sua maior diferença no verão com 3,8 segundos e a menor diferença no outono, com 2,9. Diferente do padrão encontrado para a altura significativa, o período de pico médio é maior em todas as estações no presente estudo, principalmente na primavera, quando alcança valores de 1,5 segundos acima do estudo anterior. Além disso, o desvio padrão é menor durante o verão $(-0,7)$ e outono $(-0,3)$, e maior na primavera $(0,3)$. Considerando a direção média de onda do presente estudo, ela se mostrou maior durante o verão, inverno e primavera em $4^{\circ}, 14^{\circ}$ e $10^{\circ}$, respectivamente, mantendo os mesmos valores durante o outono. Isto significa que no estudo atual, uma pequena rotação para $S$ da direção de onda média pode ser reconhecido.

Tabela 5.1: Estatística descritiva das ondulações de água profunda encontradas para os 30 anos de análise.

\begin{tabular}{|c|c|c|c|c|c|c|c|c|c|c|c|c|c|}
\hline & \multicolumn{6}{|c|}{ Hs } & \multicolumn{6}{|c|}{$T p$} & Dir \\
\hline & $\overline{\operatorname{Min}}$ & Max & Alcance & Média & Std & Var & Min & $\operatorname{Max}$ & Alcance & Média & Std & Var & Média \\
\hline Geral & 0,3 & 6,8 & 2,2 & 2,1 & 0,7 & 0,5 & 2,2 & 20,2 & 18,0 & 9,4 & 2,3 & 5,4 & 139 \\
\hline Verão & 0,3 & 5,6 & 2,2 & 1,9 & 0,6 & 0,3 & 2,2 & 19,4 & 17,2 & 8,6 & 2,1 & 4,3 & 125 \\
\hline Outono & 0,6 & 6,8 & 3,6 & 2,0 & 0,7 & 0,5 & 3,6 & 19,3 & 15,7 & 9,9 & 2,4 & 5,9 & 151 \\
\hline Inverno & 0,4 & 6,4 & 3,4 & 2,2 & 0,8 & 0,6 & 3,4 & 20,2 & 16,8 & 9,9 & 2,3 & 5,4 & 148 \\
\hline Primavera & 0,9 & 6,0 & 4,0 & 2,2 & 0,7 & 0,4 & 4,0 & 20,1 & 16,2 & 9,2 & 2,2 & 4,7 & 131 \\
\hline
\end{tabular}

Em relação às ondas mais energéticas, representadas aqui pelos grupos de onda com altura significativa maiores que dois metros, é possível reconhecer maiores valores de ocorrência quando comparados com o estudo pretérito, o qual pode ser explicado tanto pelo maior período de análise quanto pelas diferentes versões do modelo.

Tabela 5.2: Frequência de ocorrência das ondulações de água profundas mais energéticas para a série temporal de 30 anos.

\begin{tabular}{ccccc}
\hline & \multicolumn{5}{c}{ \% Ocorrência } \\
\hline Geral & $>2 \mathrm{~m}$ & $>3 \mathrm{~m}$ & $>4 \mathrm{~m}$ & $>5 \mathrm{~m}$ \\
Verão & 24,008 & 4,281 & 0,377 & 0,036 \\
Outono & 13,51 & 1,04 & 0,04 & 0,01 \\
Inverno & 21,61 & 4,10 & 0,46 & 0,04 \\
Primavera & 30,06 & 6,66 & 0,66 & 0,08 \\
\hline
\end{tabular}

Em relação à força de onda, os meses de Setembro, Julho e Junho apresentaram os valores mais elevados, com $60168,48,53560,43$ e $53552,77 \mathrm{~W} / \mathrm{m}$, respectivamente 
(Figura 5.5). Os menores valores foram representados pelos meses de Fevereiro, Janeiro e Dezembro, com 31440,55, 31980,79, e 33955,51 W/m, respectivamente. Considerando o desvio padrão para cada mês, os meses de Maio, Setembro e Abril apresentaram os maiores valores, com 11866,66, 10983,66, e 10314,68 W/m, respectivamente, enquanto que os menores valores estiveram relacionados aos meses de Janeiro, Dezembro e Março, com 6602,58, 6916,11 e 7801,87 W/m, respectivamente.

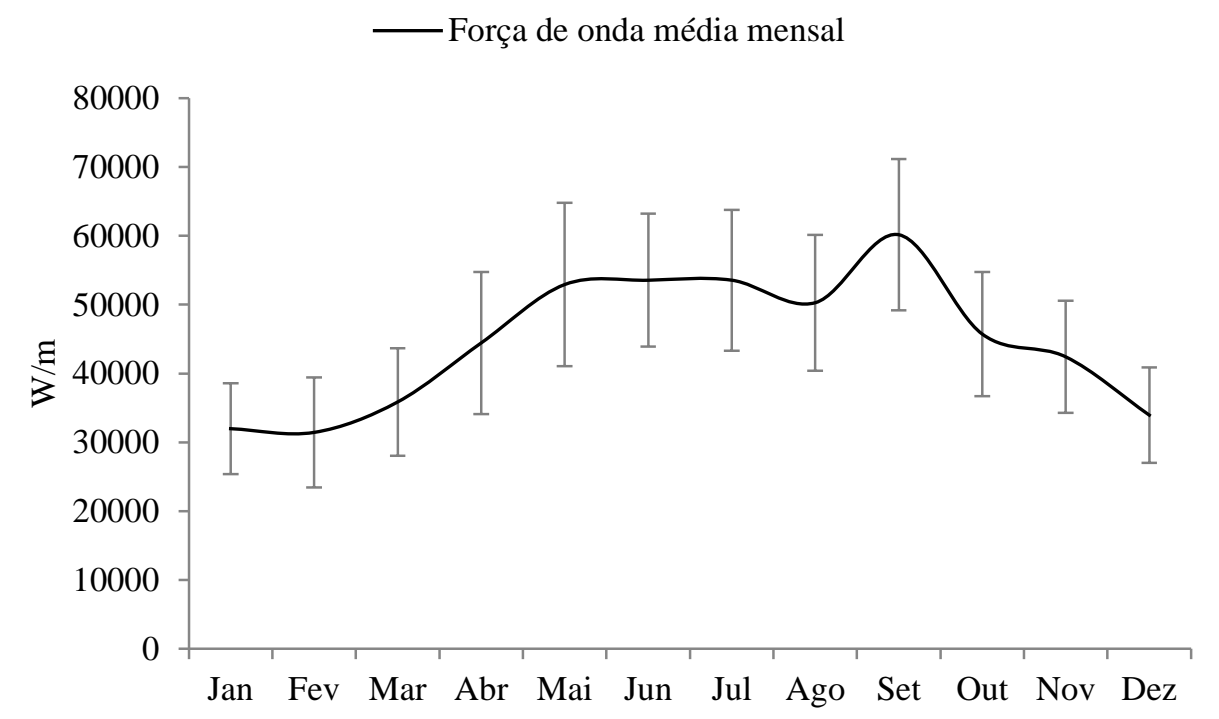

Figura 5.5: Distribuição média mensal dos valores de força de onda, a partir da série temporal de 30 anos.

\subsubsection{Deriva potencial}

A Figura 5.6 mostra a deriva potencial resultante ao longo de toda a área de estudo, evidenciando um transporte direcionado para NE, com setores de divergência e convergência residual, ou seja, relacionados apenas magnitude e não a direção. Os setores 6 e 4 apresentaram os maiores valores de transporte longitudinal, com magnitude de 170 e 159, respectivamente, seguido pelo setor 5, com 134, e pelos três setores mais ao norte, 3, 2 e 1, com valores de 80,30 e 62, respectivamente. Pontos de divergência residual foram reconhecidos entre os setores 5 e 4, na região centro-sul da ilha, e entre os setores 2 e 1, na região mais ao norte. Os maiores valores de divergência foram encontrados no setor norte, com 34, enquanto que na região centro-sul foram encontrados valores próximos a 25. Ambas as localidades apresentam indicadores morfológicos e características no sistema praia-duna de ambientes em processo erosivo ativo. Em contrapartida, as regiões entre os trechos 6-5, 4-3 e 3-2 apresentaram 
convergência residual, com valores de 36, 78 e 52, respectivamente. Tais setores apresentam praias largas as quais não apresentam feições erosivas visíveis ao longo dos compartimentos. Analisando em detalhe através de um corte longitudinal através de toda a ilha e aproximando a série através de uma regressão polinomial de modo a suavizar os ruídos dos valores ao longo a ilha, temos bem identificados os dois setores, centro-sul e norte, como áreas de divergência residual (Figura 5.7). A divergência centro-sul se inicia próximo ao quilômetro 14 , indo até próximo ao quilômetro 26,5 , enquanto a tendência norte inicia aproximadamente no quilometro 55, se estendendo até a ponta norte da ilha. As distâncias estão referenciadas com o zero aproximado na ponta sul da Ilha Comprida.

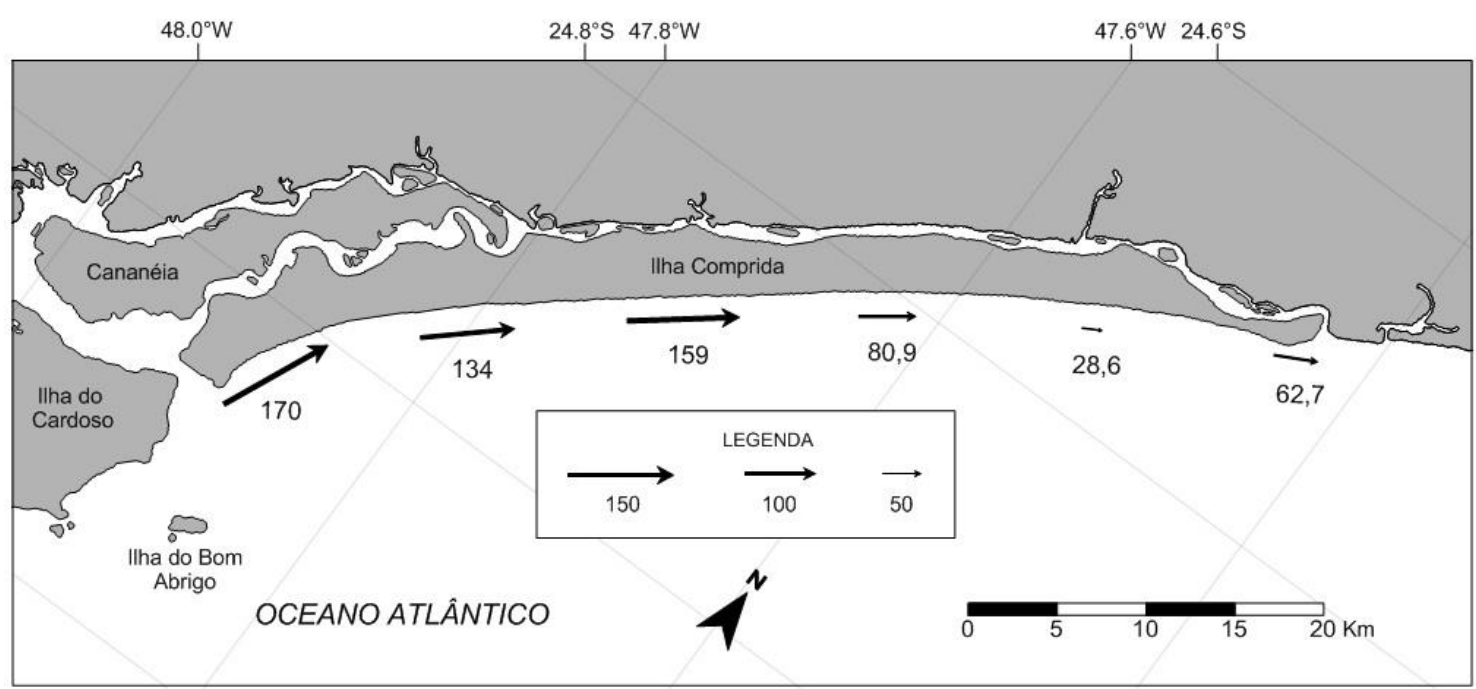

Figura 5.6: Distribuição da deriva litorânea potencial considerando a subdivisão espacial de setores adotada. Os valores são adimensionais. 


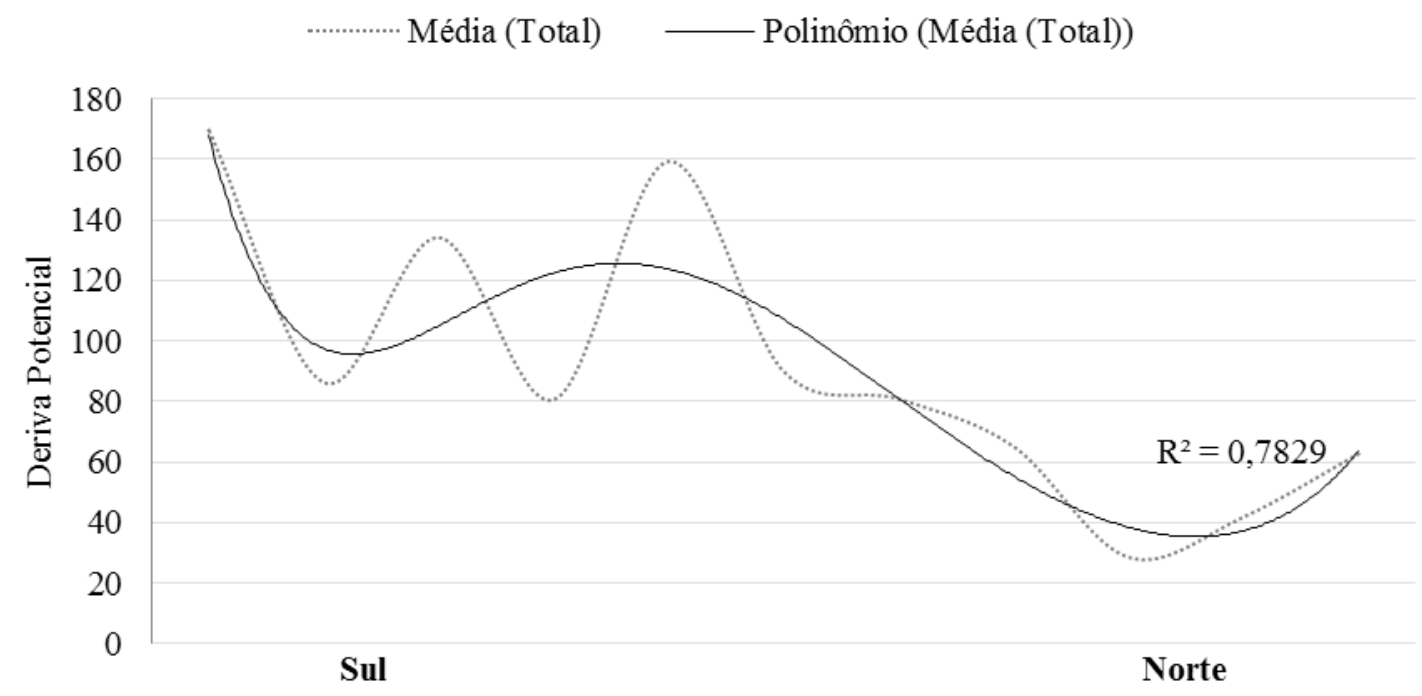

Figura 5.7: Distribuição longitudinal da deriva potencial, evidenciando a tendência geral de transporte a partir de regressão polinomial. Os valores são adimensionais.

Sazonalmente, a deriva potencial mostra variações não apenas em relação à magnitude, mas também na direção resultante do transporte (Figura 5.8). Durante o verão, com a chegada preferencial de ondas do quadrante NE-E, o transporte resultante esteve orientado para SW, apresentando dois setores principais de divergência residual entre os trechos 4-3 e 2-1. No outono, uma inversão no transporte para NE pode ser reconhecida, com uma manutenção espacial nos pontos de divergência residual entre o trecho 2-1, com uma variação na magnitude, bem como um deslocamento da divergência centro-sul para os trechos 5-4. Com a chegada do inverno, há uma intensificação na deriva para NE, sendo o período com maiores valores de transporte ao longo de toda a ilha, superiores a 400. Além disso, duas importantes considerações devem ser frisadas nesta estação: há um aumento da zona de divergência centro-sul, a qual pode ser reconhecida entre dois setores, 6-5 e 5-4; e uma manutenção espacial da divergência entre os trechos 2-1. As correntes costeiras são suavizadas com a entrada da primavera, causando uma mudança na direção de transporte no setor 6 para NE, com padrões similares de divergência e convergência se comparado com o verão. Deste modo, a divergência norte mantém sua posição espacial durante todas as estações, com uma variação de magnitude residual, sendo maior durante a primavera (67) e verão (54), seguida pelo outono (38) e inverno (36). Em contrapartida, a divergência situada na porção centro-sul não apresenta uma manutenção espacial, com a migração e crescimento de sua área de atuação para setores mais ao sul durante os meses mais energéticos, seguido de uma diminuição da sua área de atuação e retorno para regiões 
mais ao norte durante o verão. Numa perspectiva quantitativa, este setor apresenta maiores valores de divergência residual quando comparada com o setor mais ao norte, sendo mais importante durante o inverno (103 entre os trechos 6-5 e 77 entre os trechos 5-4), seguido pelo verão (66), primavera (64) e outono (34).

Através da mesma aproximação polinomial utilizada para as tendências gerais, podemos reconhecer alguns padrões melhores marcados do que nas imagens com as derivas setorizadas (Figura 5.9). Para o verão, a divergência do setor centro-sul se inicia aproximadamente no quilômetro 21, se estendendo até próximo ao quilometro 32, possuindo um alcance de aproximadamente $11 \mathrm{~km}$. Com a entrada do outono, é possível notar uma migração de tal tendência para sul, iniciando-se no quilômetro 8 e se estendendo até aproximadamente o quilometro 22, adquirindo um alcance de aproximadamente $14 \mathrm{~km}$. No inverno, um pequeno crescimento para sul ainda é notado, tendo uma tendência de início no quilometro 5, e se estendendo até o quilometro 21, adquirindo um alcance de cerca de $16 \mathrm{~km}$. Com a entrada da primavera, a divergência volta a ocupar áreas mais ao norte da ilha, tendo tendência de início no quilometro 21, se estendendo até o quilometro 33, possuindo um alcance de $12 \mathrm{~km}$. Em relação à divergência no setor norte, esta se manteve iniciando-se no quilometro 55 até a ponta da ilha em todas as estações, com exceção do inverno, onde houve uma pequena migração para setores mais ao sul, tendo inicio aproximado no quilometro 44, se estendendo até o quilometro 60, mas mantendo sua localidade entre os trechos 2-1.

É possível notar uma variabilidade sazonal bem marcada no setor de divergência centro-sul, o qual migra e aumenta sua área de atuação para SW durante meses mais energéticos, enquanto migra para NE durante o verão. Além disso, é importante frisar a manutenção espacial da divergência do setor norte durante todo o ano. Ainda, os valores de divergência no setor norte são maiores durante os meses menos energéticos, enquanto que no setor centro-sul, os maiores valores foram reconhecidos durante o inverno. 


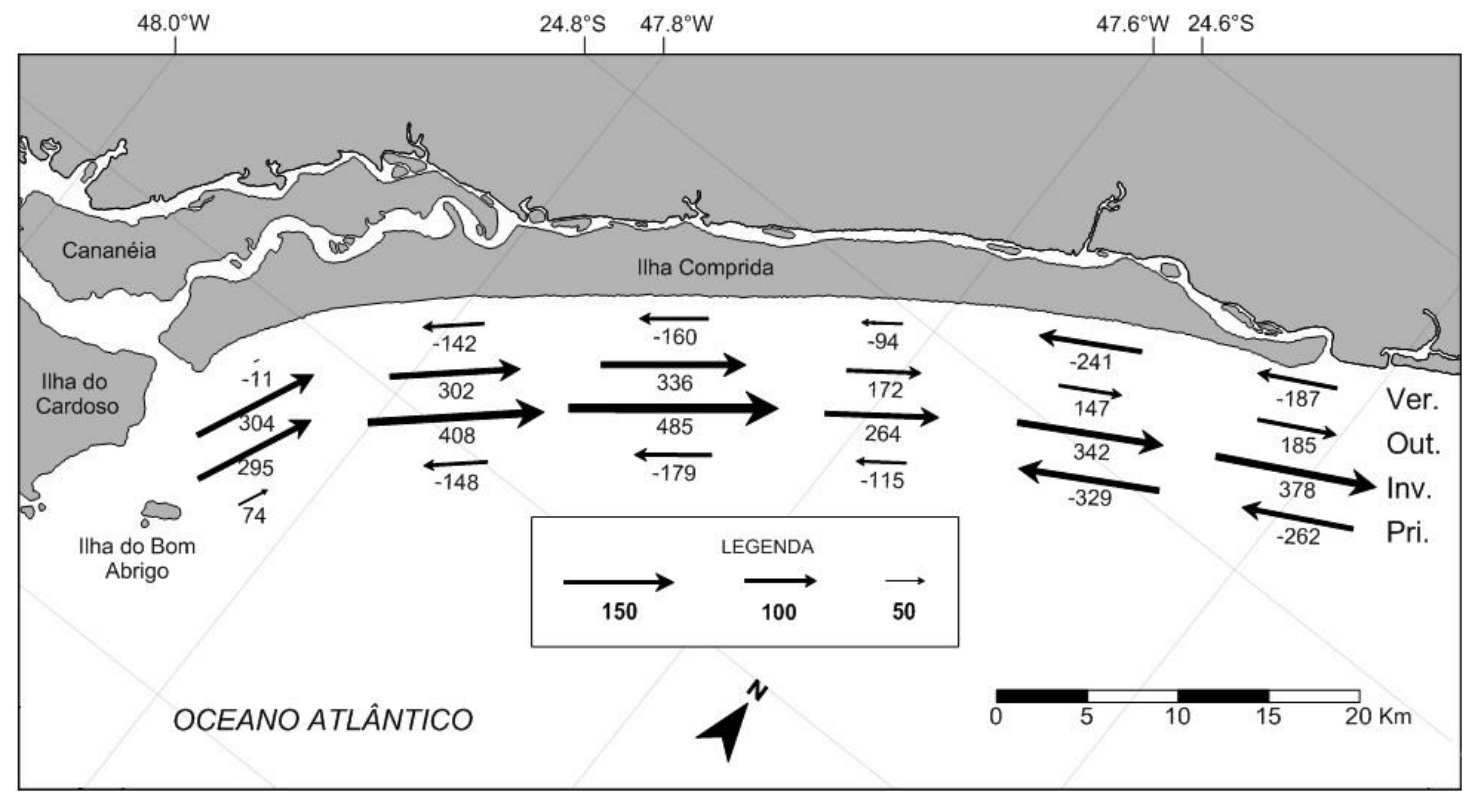

Figura 5.8: Variação sazonal da distribuição da deriva potencial, a partir da distribuição espacial de setores. Os valores são adimensionais. 

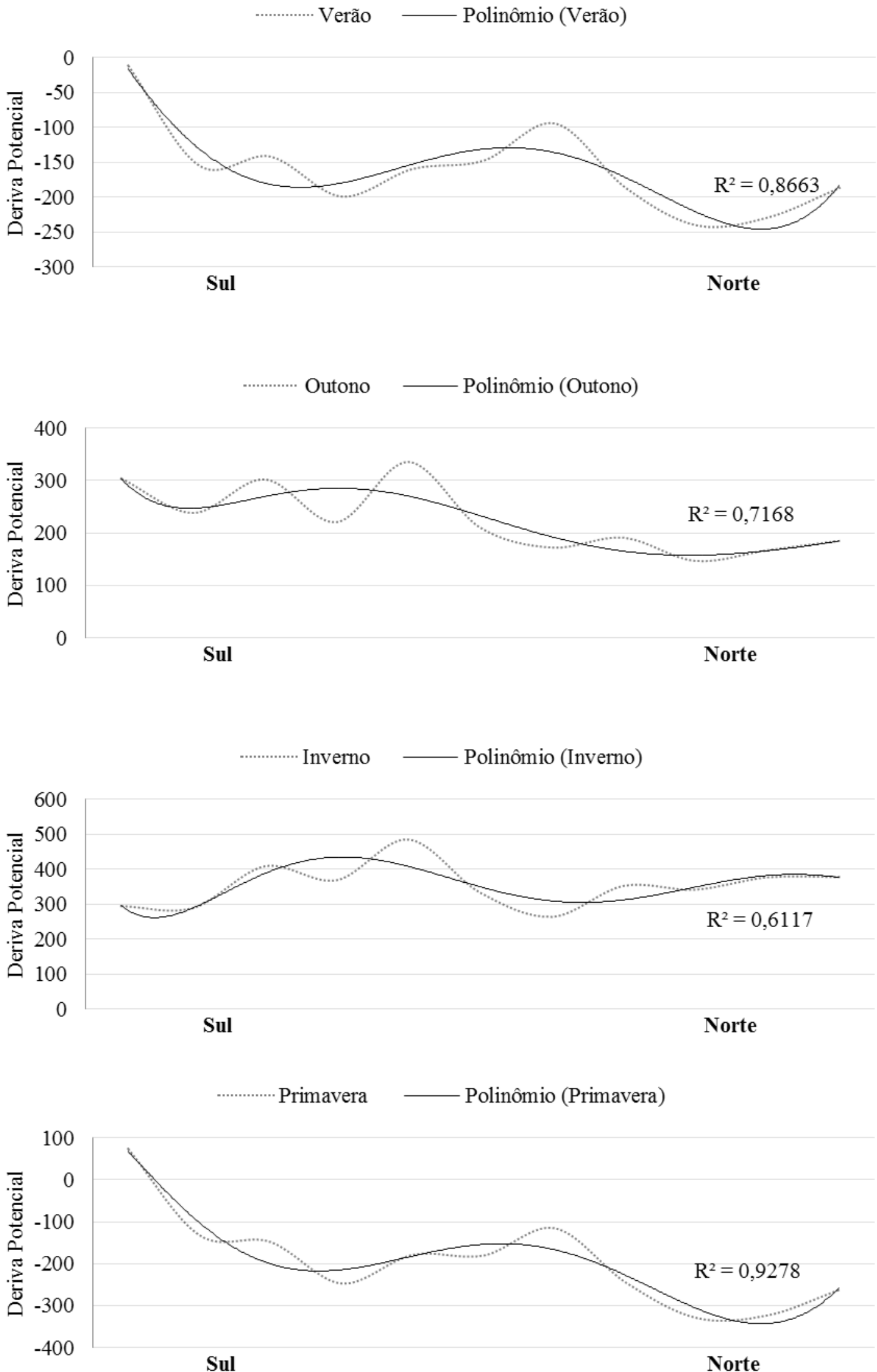

Figura 5.9: Variações sazonais da deriva litorânea potencial, considerando as tendências gerais elaboradas a partir de regressão polinomial. Os valores são adimensionais. 


\section{Força de onda}

Analisando o resultados relativos à potência de onda, é possível notar uma variação espacial de sua resultante ao longo da ilha, alcançando valores mínimos de aproximadamente $100000 \mathrm{~W} / \mathrm{m}$, e máximos de cerca de $250000 \mathrm{~W} / \mathrm{m}$ (Figura 5.10 ). Espacialmente, é possível reconhecer dois pontos onde há um relativo aumento dos valores: a região mais ao norte, entre os pontos 2 e 1 , local onde foram encontradas as intensidades máximas, com valores maiores que $250000 \mathrm{~W} / \mathrm{m}$; e a região centro sul, próxima ao ponto 3 , que também apresentou valores relativamente elevados (cerca de $220000 \mathrm{~W} / \mathrm{m})$. Em contrapartida, a região próxima aos pontos 3 e 6 apresentaram focos com valores mais amenos, sendo o mínimo encontrado na ponta sul (cerca de 100000 $\mathrm{W} / \mathrm{m})$.

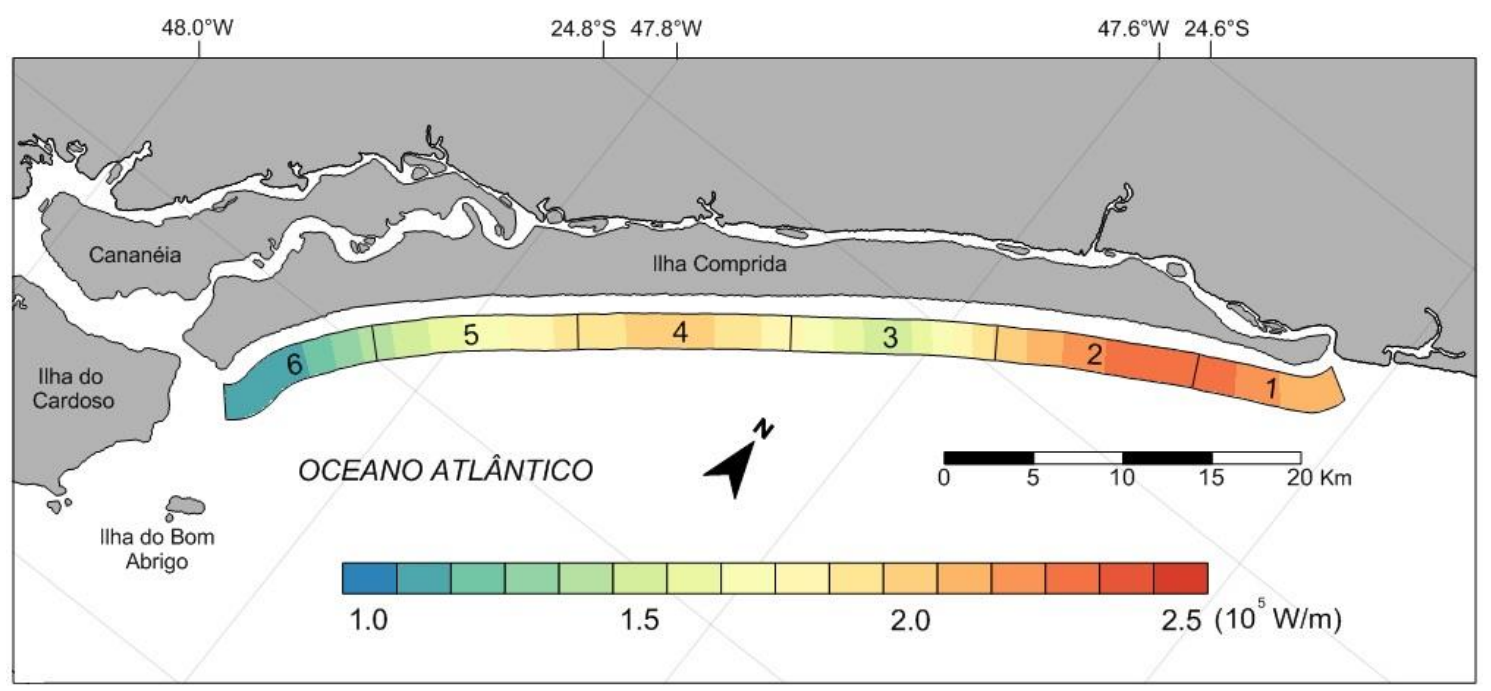

Figura 5.10: Distribuição de força de onda ao longo da costa da Ilha Comprida, considerando a série de 30 anos de dados. Os valores são apresentados $\mathrm{em} \mathrm{W} / \mathrm{m}$.

Variações sazonais também são perceptíveis em relação à potência de onda (Figura 5.11). Percebe-se que os períodos de primavera e verão apresentam condições mais amenas, com valores que não excedem $220000 \mathrm{~W} / \mathrm{m}$. Em contrapartida, os meses de outono e inverno apresentam um aumento nos valores associados, com estimativas que alcançam cerca de $380000 \mathrm{~W} / \mathrm{m}$. É importante frisar que, nos meses mais energéticos, o foco de concentração da força de onda é justamente a região mais ao norte. Além disso, comparativamente entre as regiões, é possível reconhecer um padrão de distribuição durante as estações, com uma variação gradual de intensidade em todos os pontos. Analisando a distribuição longitudinal da força de onda (Figura 5.12), para 
cada estação do ano, é possível notar que os focos com maior e menor magnitude se mantém, independente da época.

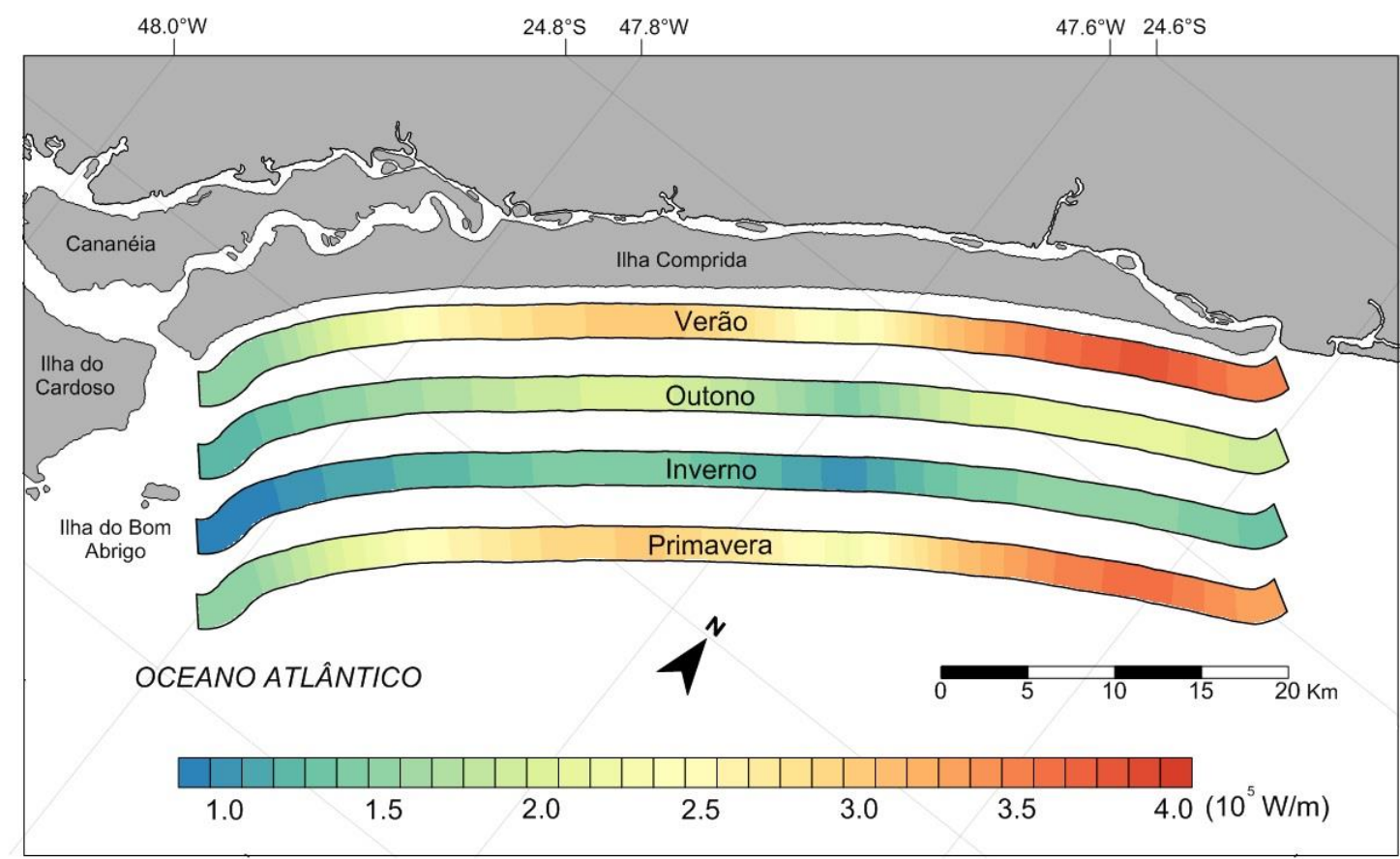

Figura 5.11: Distribuição espacial da força de onda ao longo da costa da Ilha Comprida, a partir de uma subdivisão sazonal da série de 30 anos de dados. Os valores são apresentados em W/m

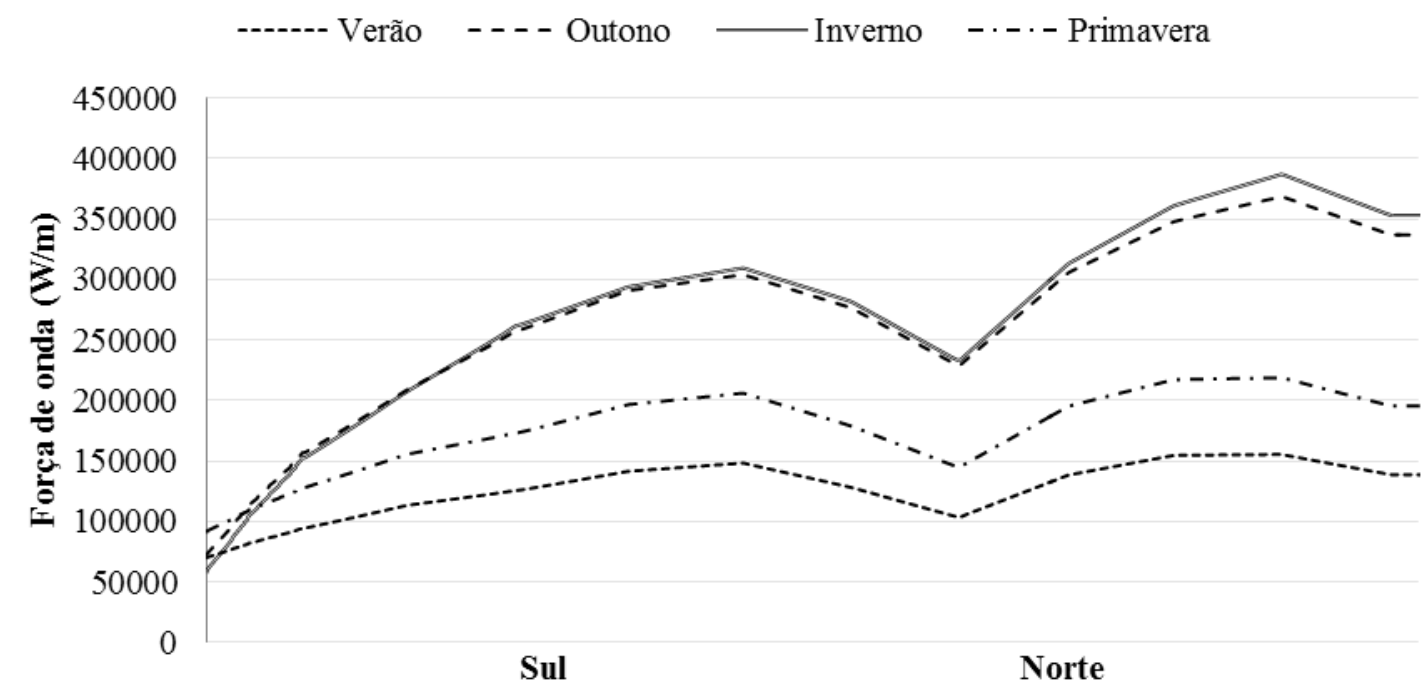

Figura 5.12: Secção longitudinal dos valores de força de onda ao longo da costa da ilha comprida. $O$ eixo y representa a força de onda, enquanto que o eixo x representa o eixo SW/NW da Ilha Comprida. 


\subsection{Escala Sazonal}

\subsubsection{Condições atmosféricas e oceanográficas}

Os processos atmosféricos atuantes durante o período de amostragem variaram consideravelmente ao longo da série temporal. A Tabela 5.3 mostra a ação dos sistemas frontais mensais e suas respectivas posições ao longo da costa brasileira.

Tabela 5.3: Número de ocorrência de sistemas frontais ao longo da América do Sul, qualquer região da costa brasileira, e especificamente no litoral sul paulista, com distribuição temporal mensal.

\begin{tabular}{c|c|c|c}
\hline Data & \multicolumn{3}{|c}{ Sistemas Frontais } \\
\hline & América do Sul & Costa Brasileira & Litoral Sul Paulista \\
\hline Fev/13* & 6 & 4 & 1 \\
\hline Mar/13* & 10 & 4 & 2 \\
\hline Abr/13 & 4 & 3 & 1 \\
\hline Mai/13 & 8 & 5 & 4 \\
\hline Jun/13* & 11 & 8 & 3 \\
\hline Jul/13 & 11 & 6 & 3 \\
\hline Ago/13* & 10 & 8 & 3 \\
\hline Set/13 & 7 & 6 & 3 \\
\hline Out/13* & 6 & 5 & 3 \\
Nov/13 & 10 & 5 & 4 \\
\hline Dez/13 & 6 & 4 & 1 \\
\hline Jan/14* & 7 & 3 & 1 \\
\hline Fev/14* & 7 & 3 & 0 \\
Mar/14 & 9 & 5 & 1 \\
Abr/14 & 8 & 5 & 3 \\
Mai/14* & 9 & 5 & 3 \\
& & & \\
\hline
\end{tabular}

Dentre os meses analisados, os meses de junho/13 e julho/13 apresentaram o maior número de ocorrência ao longo do litoral sul-americano, com 11 ocorrências, seguido dos meses de março/13, agosto/13 e novembro/13, com 10 ocorrências cada. $\mathrm{O}$ mês que apresentou menor atuação foi o de abril/13, com apenas quatro ocorrências ao longo de toda costa sul-americana. Dentre os sistemas que tiveram força suficiente para o deslocamento para latitudes da costa brasileira, os meses que apresentaram maior ocorrência foram junho/13 e agosto/13, com oito ocorrências, seguido pelos meses de julho/13 e setembro/13, com seis ocorrências cada. Neste padrão, os meses com mínima 
atuação foram os de abril/13, janeiro/14 e fevereiro/14, com 3 atuações ao longo do mês. Considerando os sistemas com capacidade de adentrar a costa paulista, os meses que apresentaram maior ocorrência foram maio/13 e novembro/13, com quatro ocorrências ao longo de cada mês. O mês de fevereiro/14 não apresentou nenhuma atuação de sistemas frontais ao longo da costa paulista, apesar de sistemas alcançarem latitudes relativas às costas de SC/PR, podendo gerar algum tipo de influência na costa sul paulista.

Histogramas direcionais foram elaborados de modo a representarem o padrão de ondulações atuantes entre cada levantamento de campo, bem como um quadro com estatísticas básicas descritivas do grupo amostral das ondas em águas profundas. Duas distribuições temporais foram abordadas: uma referente ao período completo entre um campo e outro (Tabela 5.4), e uma referente a um período de uma semana anterior ao levantamento, considerando tempo encontrado por Quartel et. al. (2008) para resposta de sistemas praiais a variações volumétricas devido a agentes de tempestade (Tabela $5.5)$.

O período de análise de ondas para o primeiro levantamento (A) compreendeu a três meses anteriores a data da coleta, seguindo o padrão regular do intervalo temporal entre as amostras. O período A foi caracterizado por ondulações com altura significativa média de 1,9 metros, com desvio padrão de 0,7 metros. A altura mínima registrada foi de 0,8 metros e a maior foi de 5,2 metros. O período de pico apresentou valores médios de 9,4 segundos, com desvio padrão de 2,4 segundos e valores mínimo e máximo de 4,7 e 17,8 segundos, respectivamente. A direção média das ondulações foi de $148,5^{\circ}$. As ondulações predominantes para o período foram ondas do quadrante S e SSW, com aproximadamente $23 \%$ de ocorrência cada, sendo a onda mais ativa no quadrante S com 1,5 metros de altura e período entre 7-9 segundos, com 9,43\% de ocorrência, enquanto que ondas de 2 metros de altura e período entre 10-11 predominaram no quadrante SSW, com 7,35\% de ocorrência (Figura 5.13).

A semana anterior ao levantamento apresentou a passagem de um sistema frontal entre os dias 7-8 de maio/13, cerca de sete dias anterior ao levantamento. Os dados mostram uma altura significativa média de 2,3 metros, com desvio padrão de 0,8 metros, sendo o máximo e mínimo definidos por 4,5 e 1,3 metros, respectivamente. A direção média das ondas para o período foi de $161^{\circ}$. Ondulações provindas do quadrante $\mathrm{S}$ foram predominantes, com cerca de $57 \%$ das ocorrências, sendo a onda mais 
representada deste quadrante composta por uma altura significativa de 1,5 metros e período entre 10-11 segundos.
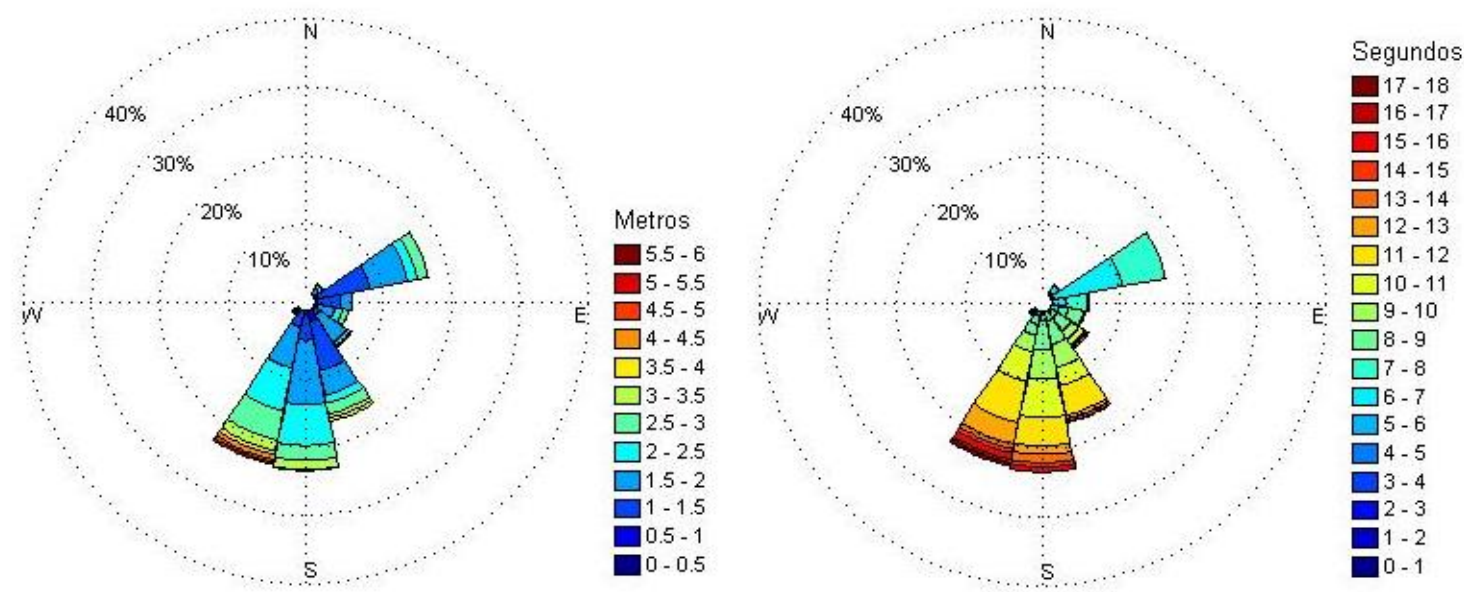

Figura 5.13: Histogramas direcionais das ondas que atuaram durante o período A. Direita: Altura significativa (Hs), em metros. Esquerda: período de pico (Tp), em segundos.

O segundo levantamento (B) foi caracterizado por ondulações com altura significativa média de 2,2 metros e desvio padrão de 0,7 metros, sendo assim superiores ao período anterior. A altura mínima registrada foi de 1 metro, enquanto que a altura máxima encontrada foi de 4,7 metros. Em relação ao período de pico, o valor médio encontrado foi de 10,7 segundos, com valores mínimos e máximos de 4,3 e 18,3 segundos, respectivamente. A direção média das ondulações foi de $166,4^{\circ}$. As ondulações predominantes para o período foram de S e SSW com 33,4 e 31,2\% de ocorrência, respectivamente, sendo a onda mais atuante provinda do quadrante $\mathrm{S}$ representada por uma altura significativa de 2 metros e período de pico entre 10-11 segundos, com 11,24\% de ocorrência, enquanto que a onda mais atuante do quadrante SSW teve 2,5 metros de altura significativa e período de pico entre 10-12 segundos, com 7,86\% de ocorrência. Percebe-se um aumento nas ondulações mais energéticas quando comparadas com o período anterior, bem como uma diminuição das ondulações de NE-E.(Figura 5.14).

A semana anterior ao levantamento apresentou a passagem de um sistema frontal no dia 10 de agosto/13, três dias anterior ao levantamento. Os dados de mostram uma altura significativa média de 2,2 metros, com desvio padrão de 0,6 metros, sendo os máximos e mínimos definidos por 3,6 e 1,5 metros, respectivamente. A direção média das ondas para o período foi de $138^{\circ}$. Ondulações provindas do quadrante $\mathrm{S}$ foram 
predominantes, com cerca de 36\% das ocorrências, sendo a onda mais representada deste quadrante composta por uma altura significativa de 2 metros e período entre 7-8 segundos.
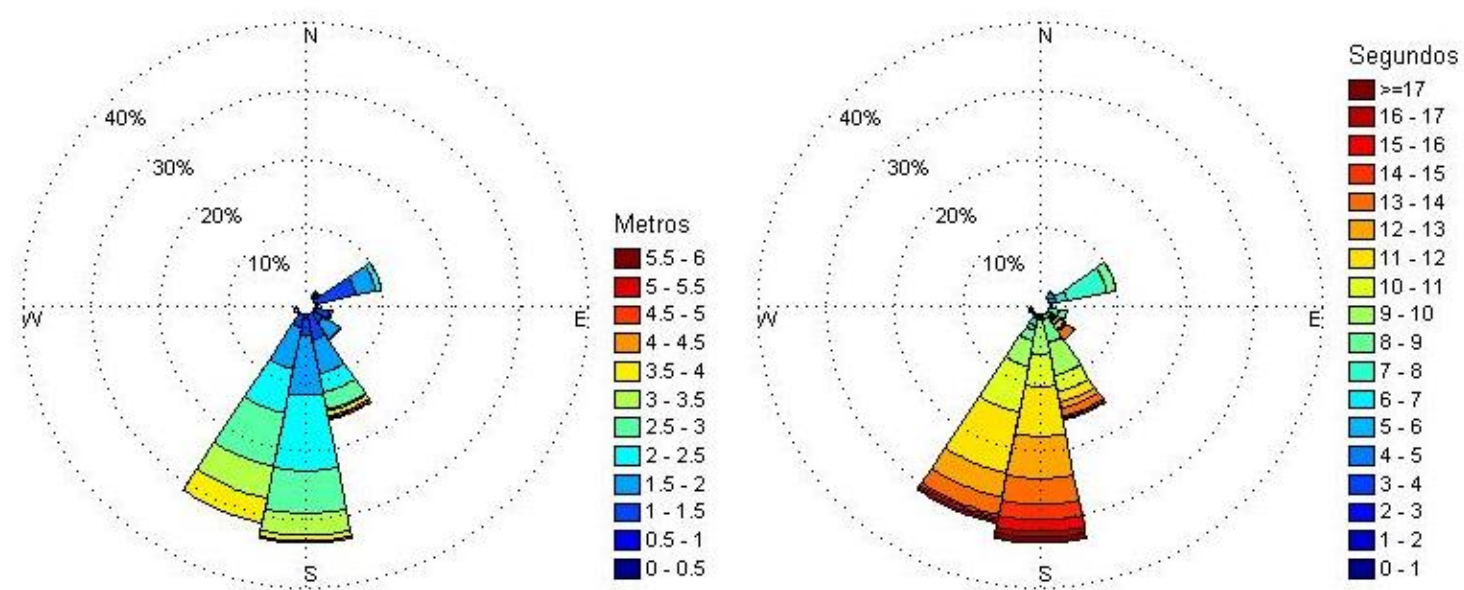

Figura 5.14: Histogramas direcionais das ondas que atuaram durante o período B. Direita: Altura Significativa (Hs), em metros. Esquerda: Período de pico (Ts), em segundos.

O terceiro levantamento (C) apresentou uma mudança brusca nos padrões de onda encontrados, sendo caracterizado por ondulações superiores ao período anterior, com altura significativa média de 2,5 metros e desvio padrão de 0,7 metros. A altura mínima registrada foi de 1,3 metros, enquanto que a altura máxima encontrada foi de 5,7 metros. O período de pico registrou uma diminuição, com valor médio de 9,1 segundos e valores mínimos e máximos de 4,8 e 14 segundos. A direção média das ondulações foi de $127,5^{\circ}$, valor menor que o período B. As ondulações predominantes para o período foram de E e ENE com 23,5 e 19,6\% de ocorrência, respectivamente, sendo a onda mais atuante provinda do quadrante E representada por uma altura significativa de 2 metros e período de pico entre 8-9 segundos, com 12,04\% de ocorrência, enquanto que a onda mais atuante do quadrante ENE teve 1,5 metros de altura significativa e período de pico entre 7-9 segundos, com 6,92\% de ocorrência. Vale frisar que ondulações dos quadrantes SSE, S e SSW também tiveram contribuições significativas com 12,2, 11,6 e 13,7\% de ocorrência. Apesar de apresentar altura média de onda elevada, este período apresentou grande concentração de ondas de NE-E, diferentemente do que os períodos A e B.

A semana anterior ao levantamento apresentou a passagem de um sistema frontal no dia 4 de novembro/13, um dia antes do levantamento. Os dados mostram altura 
significativa média de 3,2 metros, com desvio padrão de 0,4 metros. A direção média das ondas para o período foi de $186^{\circ}$, evidenciando grande contribuição de ondulações energéticas do quadrante $\mathrm{S}$, as quais foram predominantes (cerca de 95\%). A onda mais representada deste quadrante possui altura significativa de 3 metros e período entre 9-10 segundos.
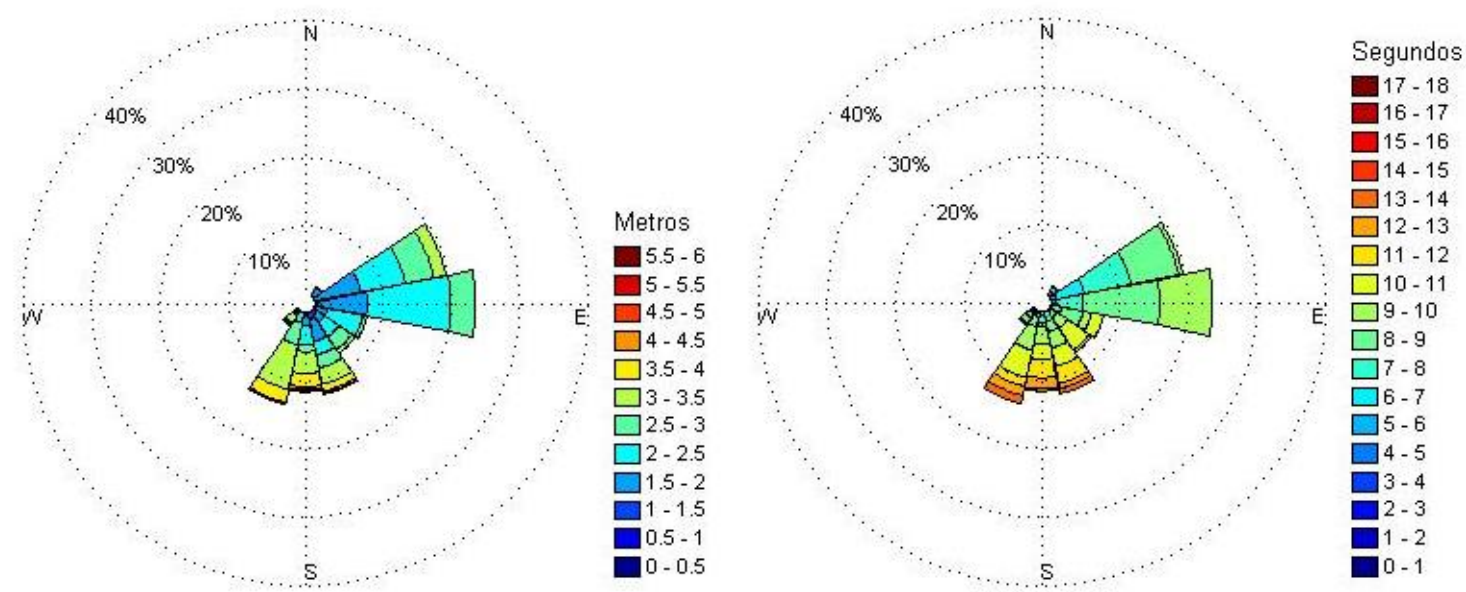

Figura 5.15: Histogramas direcionais das ondas que atuaram durante o período C. Direita: Altura significativa (Hs), em metros. Esquerda: Período de pico (Ts), em segundos.

O quarto levantamento (D) foi caracterizado por ondulações com altura significativa média de 2 metros e desvio padrão de 0,7 metros. A altura mínima registrada foi de 0,9 metros, enquanto que a altura máxima encontrada foi de 4,6 metros. Em relação ao período de pico, o valor médio encontrado para o período foi de 8,3 segundos, com valores mínimos e máximos de 5,4 e 17,2 segundos. A direção média das ondulações foi de $119,4^{\circ}$, sendo menor que os períodos anteriores. As ondulações predominantes foram de ENE e SSW com 34,9 e 16,2\% de ocorrência, respectivamente. Vale frisar que ondulações dos quadrantes $S$ e $E$ também tiveram contribuições significativas com 15,4 e $14,3 \%$ de ocorrência, respectivamente. Este período, caracterizado pela estação de verão, mostra claramente o padrão esperado, com grande contribuição de ondas do quadrante NE, devido a baixa frequência de frentes frias para esta estação.

A semana anterior ao levantamento não apresentou passagem de um sistema frontal. Os dados mostram uma altura significativa média de 1,8 metros, com desvio padrão de 0,2 metros. A direção média das ondas para o período foi de $66^{\circ}$. Ondulações provindas do quadrante NE foram predominantes, com cerca de $62 \%$ das ocorrências, 
sendo a onda mais representada deste quadrante composta por uma altura significativa de 1,5 metros e período entre 5-7 segundos.
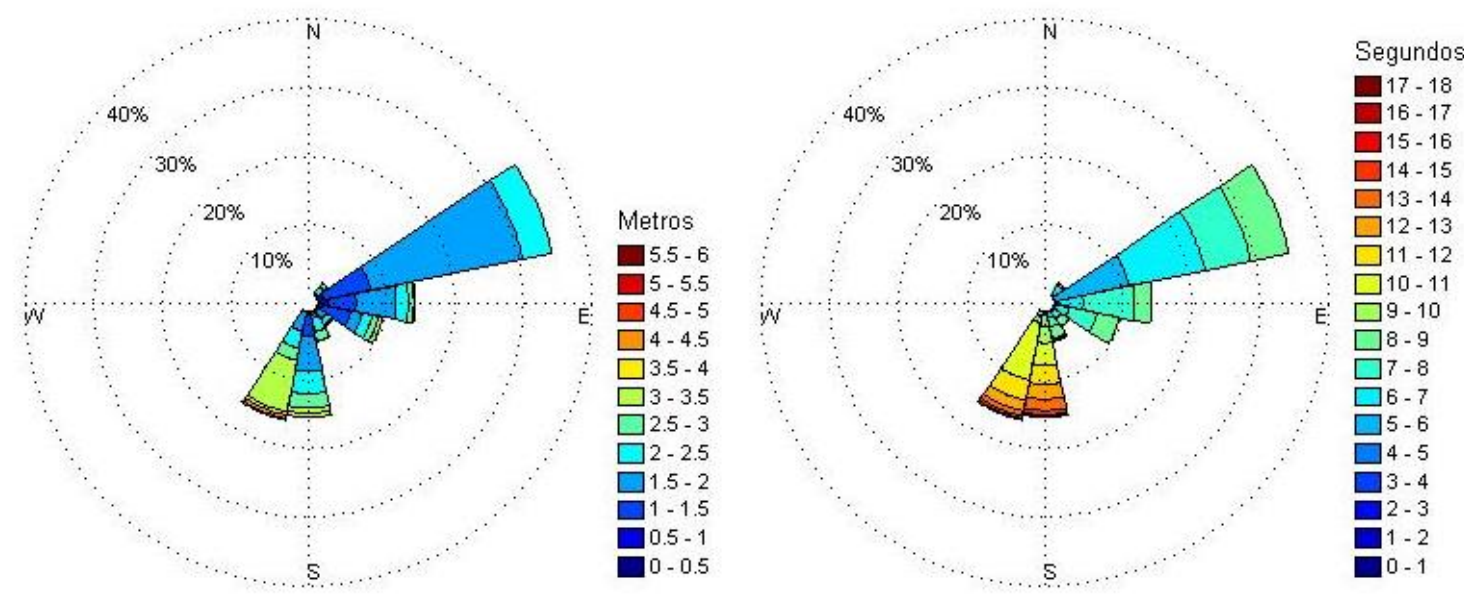

Figura 5.16: Histogramas direcionais das ondas que atuaram durante o período D. Direita: Altura significativa (Hs), em metros. Esquerda: Período de pico (Ts), em segundos.

O último levantamento (E) foi caracterizado por ondulações com altura significativa média de 1,9 metros, com desvio padrão de 0,6 metros, sendo menores que o período anterior. A altura mínima registrada foi de 0,8 metros, enquanto que a altura máxima encontrada foi de 4,6 metros. O período de pico médio encontrado foi de 7,8 segundos e desvio padrão de 1,3 segundos, com valores mínimos e máximos de 5,7 e 11,8 segundos, respectivamente. A direção média das ondulações foi de $124,1^{\circ}$, superior ao período anterior. Para este campo, é importante frisar que praticamente seis quadrantes distintos tiveram contribuições significativas e similares entre si, sendo tais: SSE, com 17,47\% de ocorrência; ENE, com 16,8\% de ocorrência; ESE e S, ambos com $16,53 \%$ de ocorrência; E com 16,3\% de ocorrência e por fim SE, com 14,7\% de ocorrência.

Este período representa a estação outono, e comparando com os dados do período A, também de outono, podemos fazer algumas relações. O período A mostrou uma menor homogeneidade dos quadrantes atuantes, com maior ocorrência apenas para os quadrantes S e SSW, enquanto o levantamento E apresentou vários quadrantes com atuações significativas. Apesar disso, a altura de onda média para ambos foram a mesma, sendo o período médio para A superior ao de $\mathrm{E}$.

A semana anterior ao levantamento apresentou a passagem de um sistema frontal entre os dias 8-9 de maio/14, cerca de cinco dias antes do levantamento. Os dados 
mostram uma altura significativa média de 2,1 metros e desvio padrão de 0,6 metros, sendo o máximo e mínimo definidos por 1,3 e 3,3 metros. A direção média das ondas para o período foi de $131^{\circ}$, similar a do período inteiro. Ondulações provindas do quadrante $\mathrm{E}$ foram predominantes, com cerca de $40 \%$ das ocorrências, sendo a onda mais representada deste quadrante composta por uma altura significativa de 1 metro e período entre 7-8 segundos.
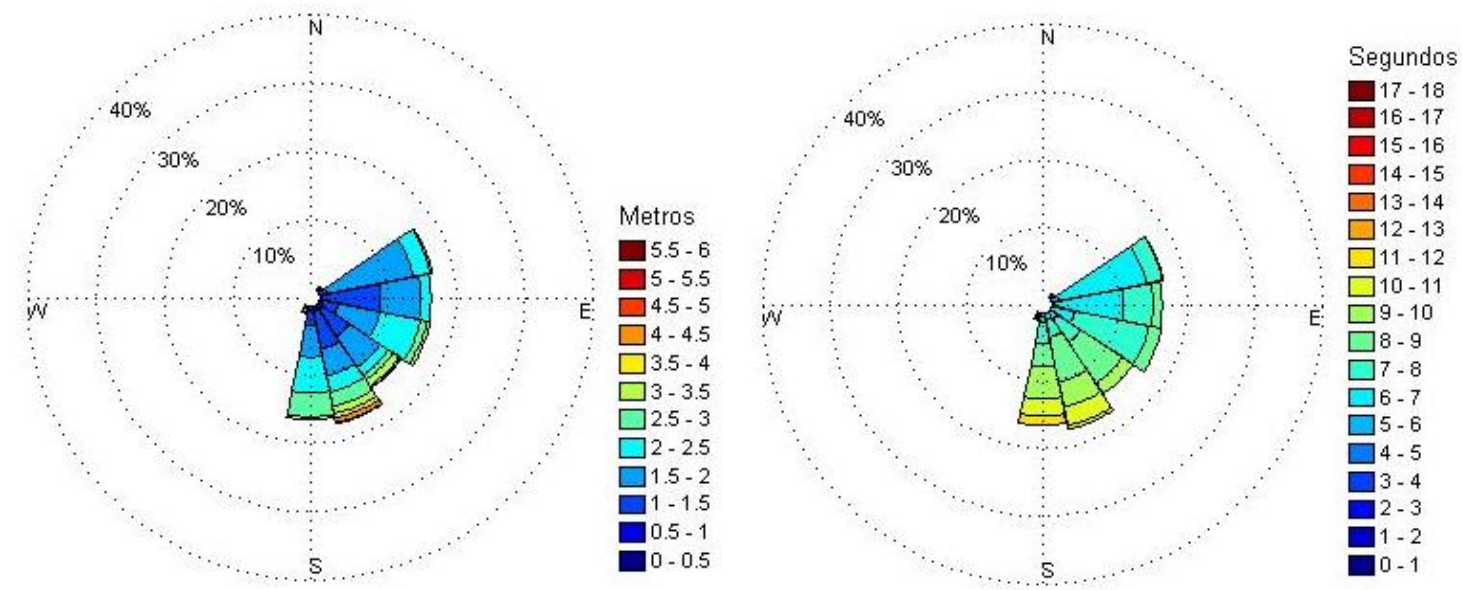

Figura 5.17: Histogramas direcionais das ondas que atuaram durante o período E. Direita: Altura significativa (Hs), em metros. Esquerda: Período de pico (Ts), em segundos.

Tabela 5.4: Estatística descritiva dos dados de onda referente ao período entre os diferentes levantamentos de campo.

\begin{tabular}{|c|c|c|c|c|c|c|c|c|c|c|c|c|c|}
\hline Período & \multicolumn{6}{|c|}{$H s$} & \multicolumn{6}{|c|}{$T p$} & Dir \\
\hline Campo & Min & Max & Alcance & Média & Std & Var & Min & Max & Alcance & Média & Std & Var & Média \\
\hline A & 0,8 & 5,2 & 4,4 & 1,9 & 0,7 & 0,5 & 4,7 & 17,8 & 13,1 & 9,4 & 2,4 & 5,6 & 148 \\
\hline B & 1,0 & 4,7 & 3,7 & 2,2 & 0,7 & 0,5 & 4,3 & 18,3 & 14,0 & 10,7 & 2,4 & 5,9 & 166 \\
\hline C & 1,3 & 5,7 & 4,3 & 2,5 & 0,7 & 0,5 & 4,8 & 14,0 & 9,2 & 9,1 & 1,7 & 2,8 & 127 \\
\hline D & 0,9 & 4,6 & 3,7 & 2,0 & 0,7 & 0,5 & 5,4 & 17,2 & 11,9 & 8,3 & 2,2 & 4,8 & 119 \\
\hline $\mathbf{E}$ & 0,8 & 4,6 & 3,7 & 1,9 & 0,6 & 0,4 & 5,7 & 11,8 & 6,0 & 7,8 & 1,3 & 1,7 & 124 \\
\hline
\end{tabular}

Tabela 5.5: Estatística descritiva dos dados de onda referentes a semana anterior ao levantamento de campo.

\begin{tabular}{|c|c|c|c|c|c|c|c|c|c|c|c|c|c|}
\hline Semana & \multicolumn{6}{|c|}{$H s$} & \multicolumn{6}{|c|}{$T p$} & Dir \\
\hline Campo & Min & Max & Alcance & Média & Std & Var & Min & Max & Alcance & Média & Std & Var & Média \\
\hline A & 1,3 & 4,5 & 3,2 & 2,3 & 0,8 & 0,7 & 5,2 & 12,8 & 7,6 & 9,1 & 2,1 & 4,4 & 161 \\
\hline B & 1,5 & 3,6 & 2,1 & 2,2 & 0,6 & 0,4 & 6,9 & 13,9 & 7,0 & 9,4 & 2,0 & 4,0 & 138 \\
\hline C & 2,3 & 3,9 & 1,6 & 3,2 & 0,4 & 0,2 & 9,3 & 13,2 & 3,9 & 10,8 & 1,0 & 0,9 & 186 \\
\hline D & 1,6 & 2,4 & 0,8 & 1,8 & 0,2 & 0,0 & 5,6 & 7,6 & 2,1 & 6,5 & 0,6 & 0,4 & 66 \\
\hline $\mathbf{E}$ & 1,3 & 3,3 & 2,0 & 2,1 & 0,6 & 0,4 & 7,6 & 9,3 & 1,7 & 8,1 & 0,4 & 0,2 & 131 \\
\hline
\end{tabular}




\subsubsection{Deriva Potencial}

Em relação à deriva potencial, foram elaborados para cada período de análise mapas vetoriais referentes ao período inteiro e a semana anterior ao levantamento. Cortes longitudinais com uma aproximação polinomial foram elaborados apenas para a média de todos os períodos, para análise da tendência geral da área

Para o período A, temos uma deriva predominante para NE, sendo os maiores valores situados nos trechos 3, 2 e 5, com cerca de 407, 311 e 249, respectivamente (Figura 5.18). Setores de divergência para tais setores foram constatados entre os setores 6-5 e 4-3. Os setores de convergência residual foram entre os setores 5-4, 3-2 e 2-1. Importante frisar que, neste período de análise, a divergência do setor norte, sempre fixa numa análise de tendência de longo-termo, se mostrou ausente, sendo os dois setores de divergência apresentados resultados ou de um deslocamento da mesma para sul, quanto do desmembramento da célula centro-sul em duas células menores na escala de análise.

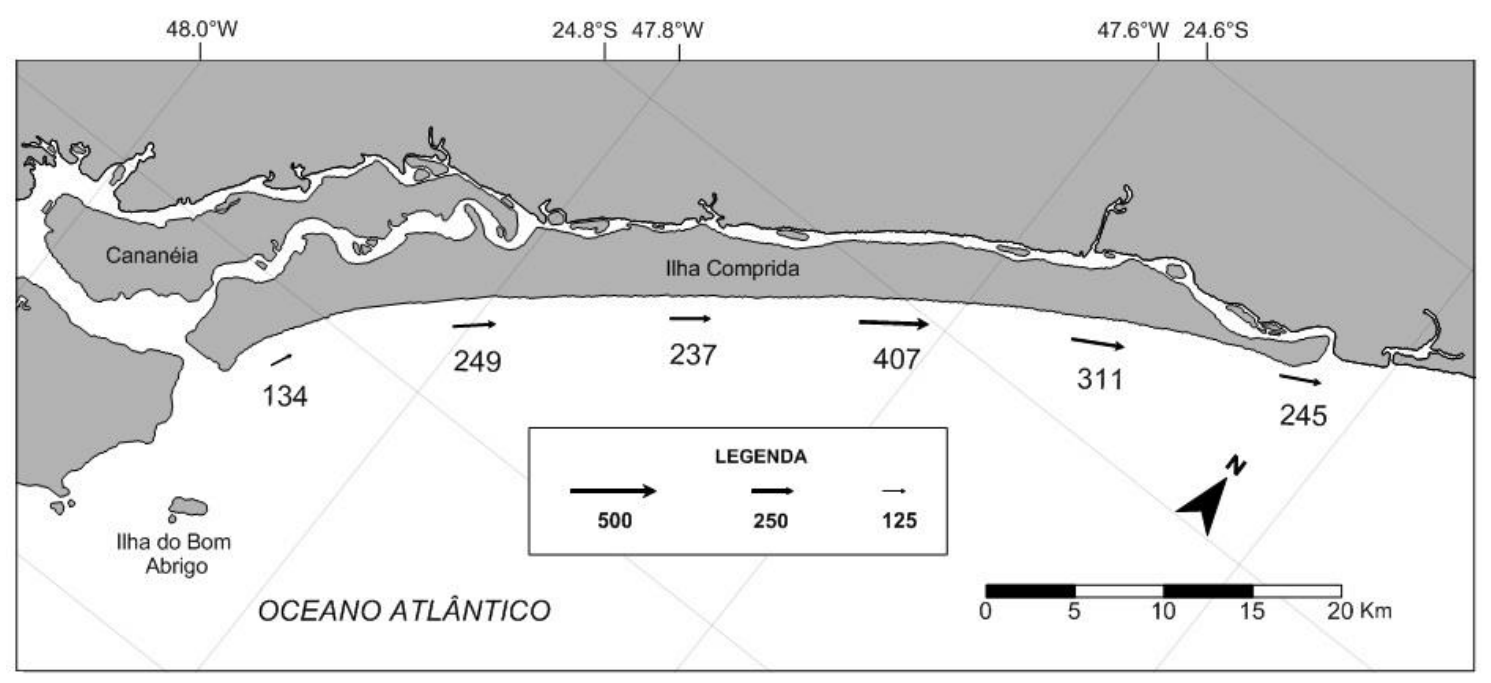

Figura 5.18: Distribuição da deriva potencial ao longo dos setores de análise para o período A.

O mapa semanal mostra uma tendência de retirada longitudinal de sedimento, com divergência residual entre os trechos 6-5, 5-4, 4-3, e 2-1, sendo o único centro de convergência localizado na porção centro-norte (Figura 5.19). Os maiores valores foram encontrados na porção norte da ilha, com valores entre 550 e 700 para todos os três trechos desta área. 


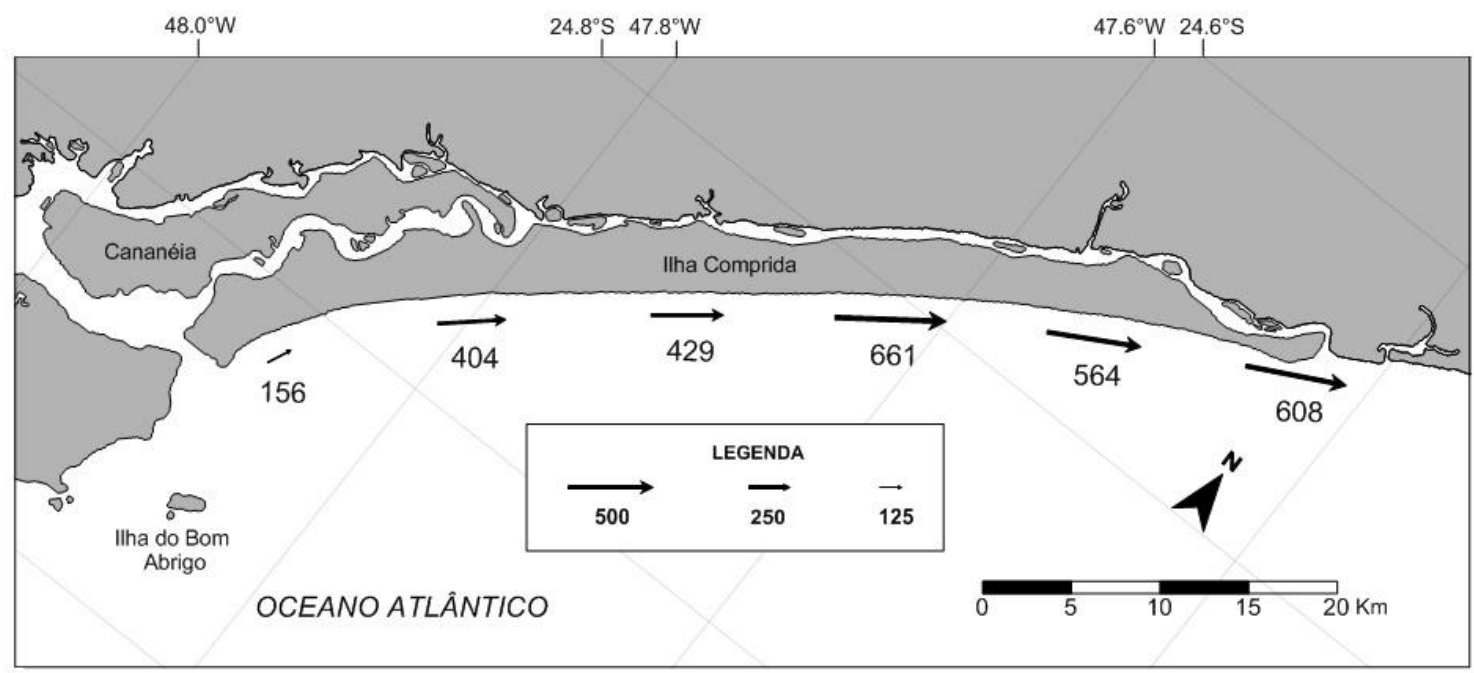

Figura 5.19: Distribuição da deriva potencial ao longo dos setores de análise considerando apenas a última semana do período A.

Em relação ao período $\mathrm{B}$, percebe-se um aumento da força do transporte longitudinal em relação ao período anterior para toda a extensão da ilha, com valores variando de cerca de 350 até próximos a 900 (Figura 5.20). Os setores de divergência residual encontrados estão situados entre os trechos 6-5 e 4-3, sendo todos os outros setores atribuídos a convergências residuais. Deste modo, este período apesar de apresentar maior força de transporte longitudinal, ele apresentou uma manutenção espacial dos setores de divergência e convergência residual, se comparado com o período A.

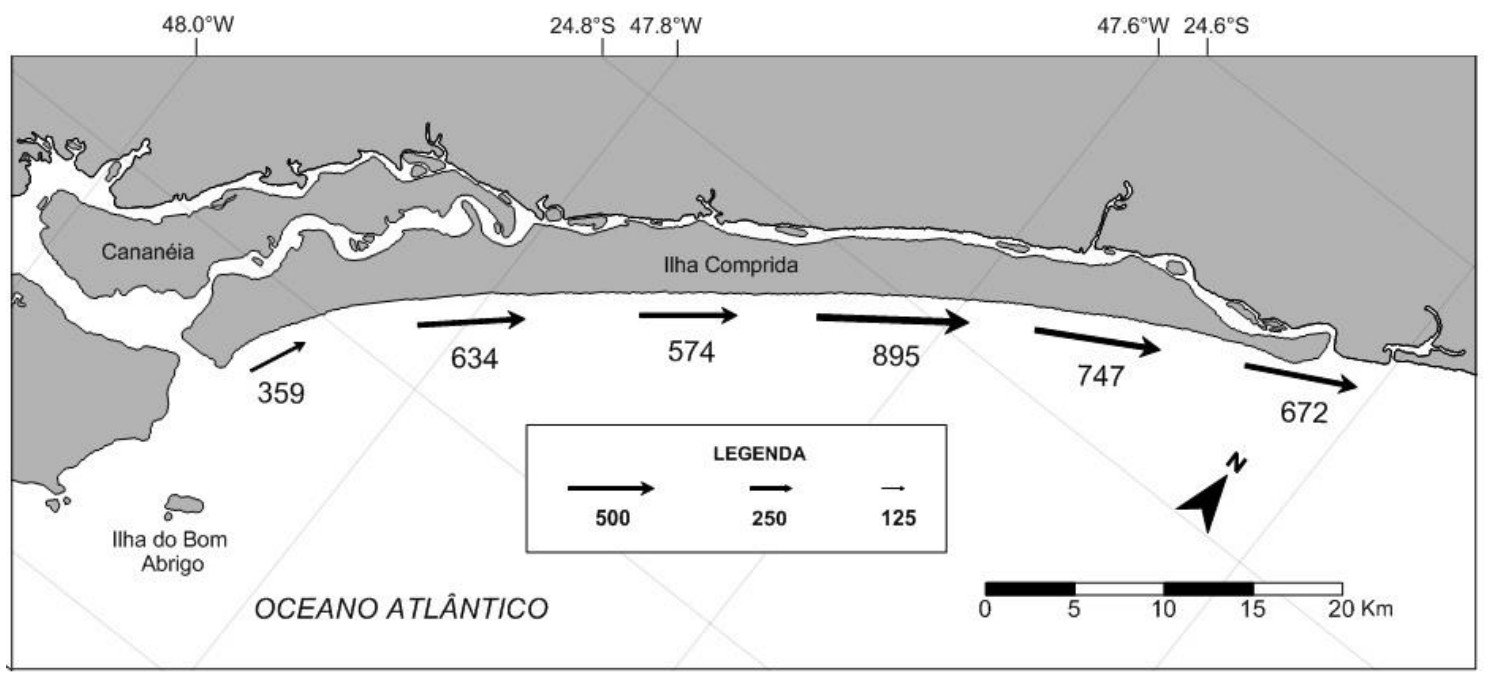

Figura 5.20: Distribuição da deriva potencial ao longo dos setores considerando o período B.

A deriva para a semana anterior ao levantamento B se mostrou bem amena na maioria dos trechos, com exceção aos setores 3 e 1, que apresentaram valores altos de 132 e -207 (Figura 5.21). Tal fato pode ser compreendido pela direção médias das ondas 
neste período, que foi do quadrante que não favorece o transporte longitudinal para o azimute médio da ilha. Entretanto, este mapa apresenta regiões de divergência e convergência não apenas residuais, mas também direcionais, entre os setores 4-3 e 2-1. A região central apresenta uma divergência direcional acentuada principalmente pelo alto valor de deriva do setor 3, alcançando valores resultantes de aproximadamente 150. Na região norte, uma elevada convergência direcional foi reconhecida, com valores aproximados em 210.

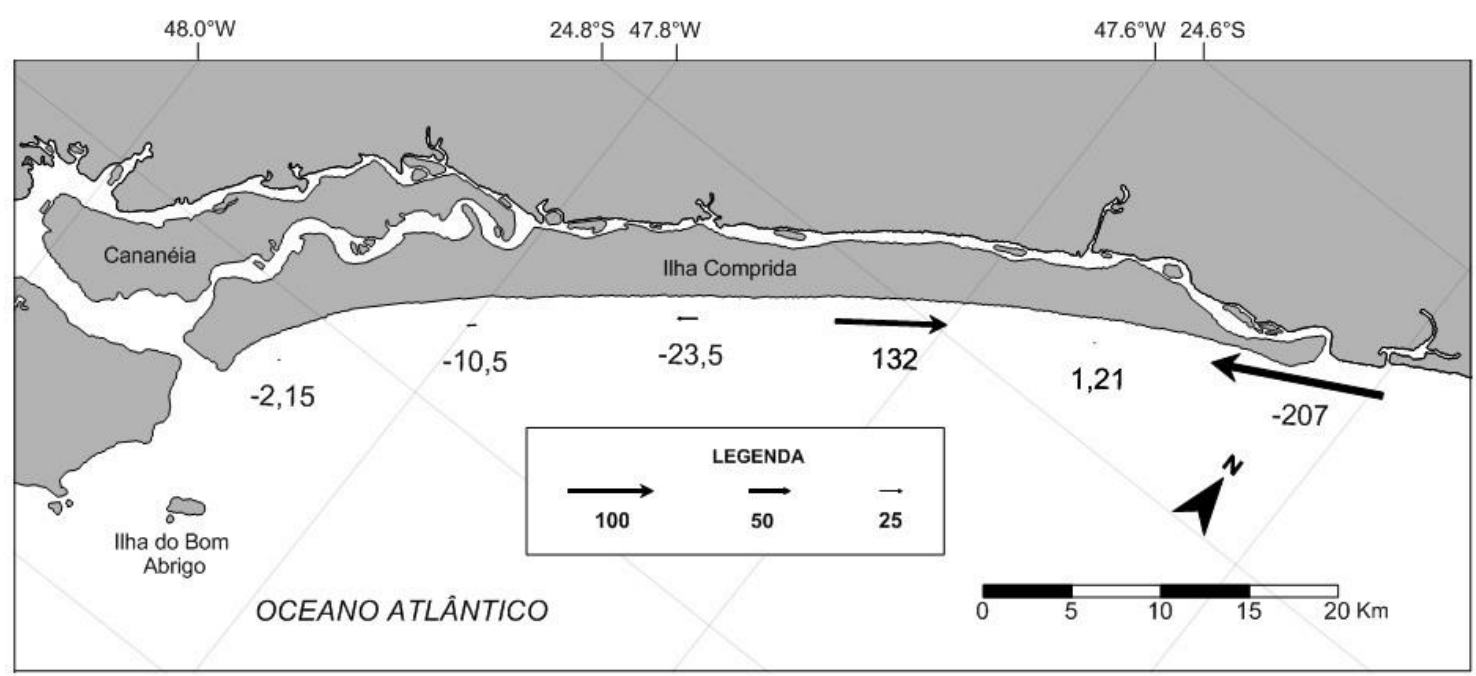

Figura 5.21: Distribuição da deriva potencial ao longo dos setores considerando apenas a última semana do período B.

A Figura 5.22 mostra a deriva para o período $\mathrm{C}$, a qual esteve direcionada para SW em toda sua extensão, com valores mais elevados nos trechos 1, 2 e 5, com -860, 556 e -497 , respectivamente. Dois setores de divergência residual foram reconhecidos, entre os trechos 5-4 e 4-3. Entretanto, ambos não atingiram -5 em magnitude. Os outros trechos apresentaram situações de convergência, sendo o mais proeminente o setor entre os trechos 2-1, com valores acima de 300. 


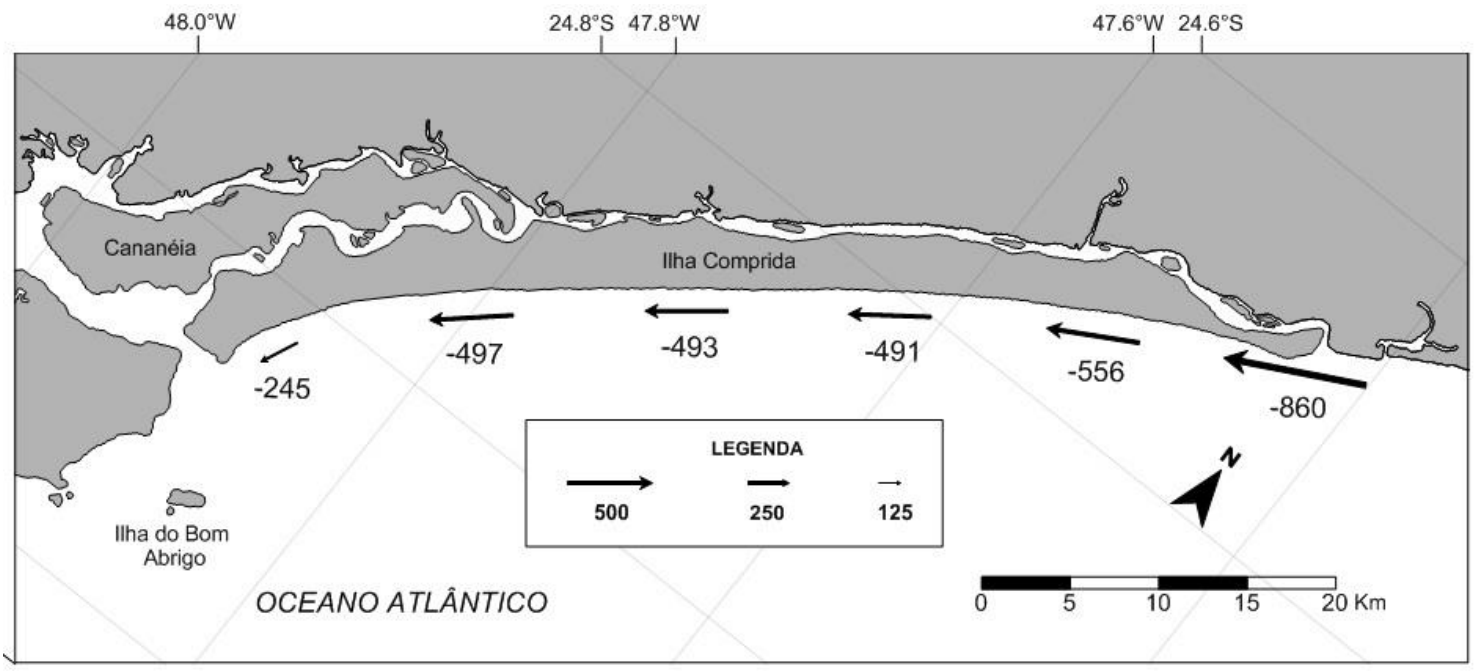

Figura 5.22: Distribuição da deriva potencial ao longo dos setores considerando o período C.

A semana anterior a $\mathrm{C}$ foi reconhecida por uma forte deriva para NE, efeito de uma frente fria que adentrou o setor um dia anterior ao levantamento (Figura 5.23). Os valores encontrados foram de 1000 em praticamente todos os trechos, com exceção do trecho 6, sendo maiores nos trechos 3, 2 e 1, com 1909, 1604 e 1549. Trechos de divergência foram reconhecidos entre os setores 6-5 e 4-3, sendo os outros setores reconhecidos por tendências de convergência residual.

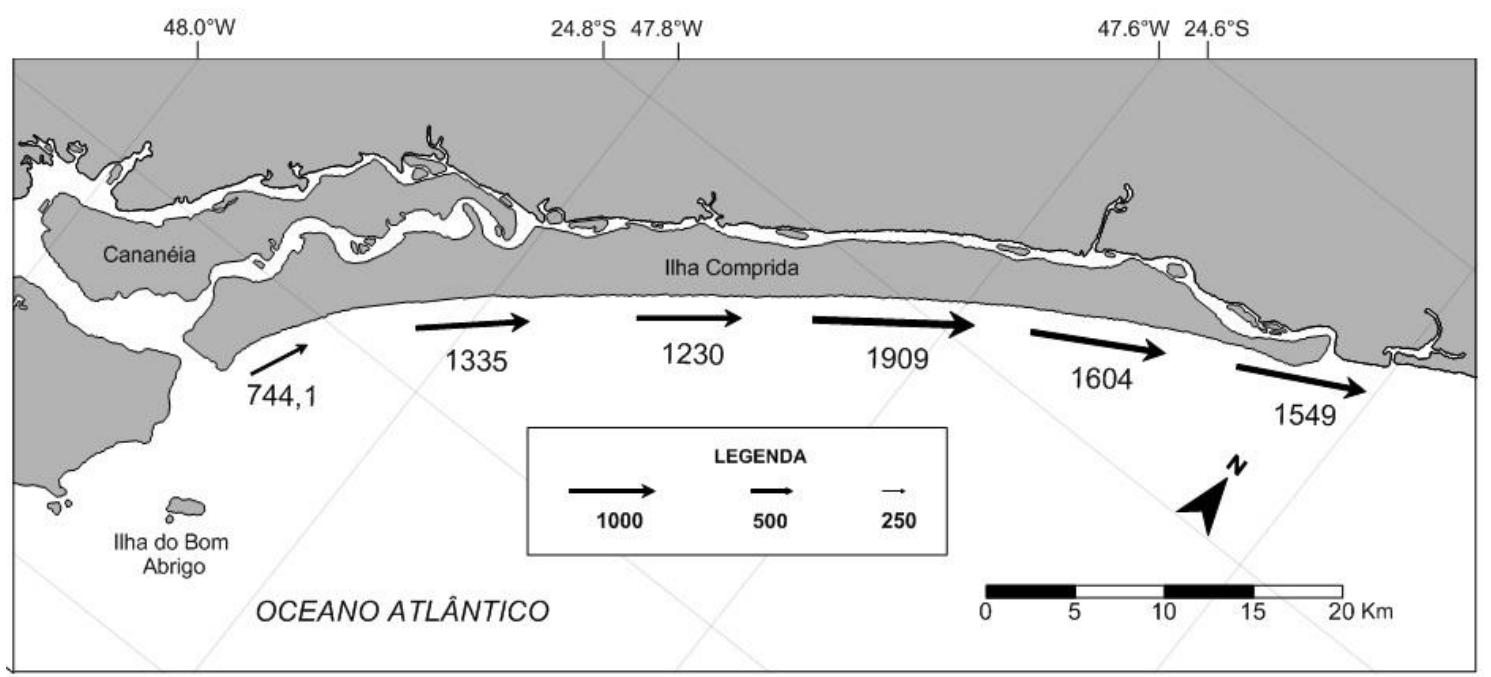

Figura 5.23: Distribuição da deriva potencial ao longo dos setores considerando apenas a última semana do período C.

O período D apresentou uma tendência geral de transporte direcionado para SW, com exceção do trecho 4, que apresentou transporte para NE (Figura 5.24). Os maiores valores foram encontrados nos trechos 1, 6 e 5 , com $-107,-75,8$ e -73 . 
Comparativamente com os outros períodos, apresentou uma deriva amena, com valores menores que 100 na maioria dos trechos. Em relação aos setores de divergência residual, estes foram encontrados entre os trechos 6-5 e 5-4, com um centro de divergência direcional entre os trechos 4-3. Os pontos de convergência se encontraram entre os trechos 3-2 e 2-1, sendo o primeiro condicionado por uma convergência direcional e o segundo por uma convergência residual.

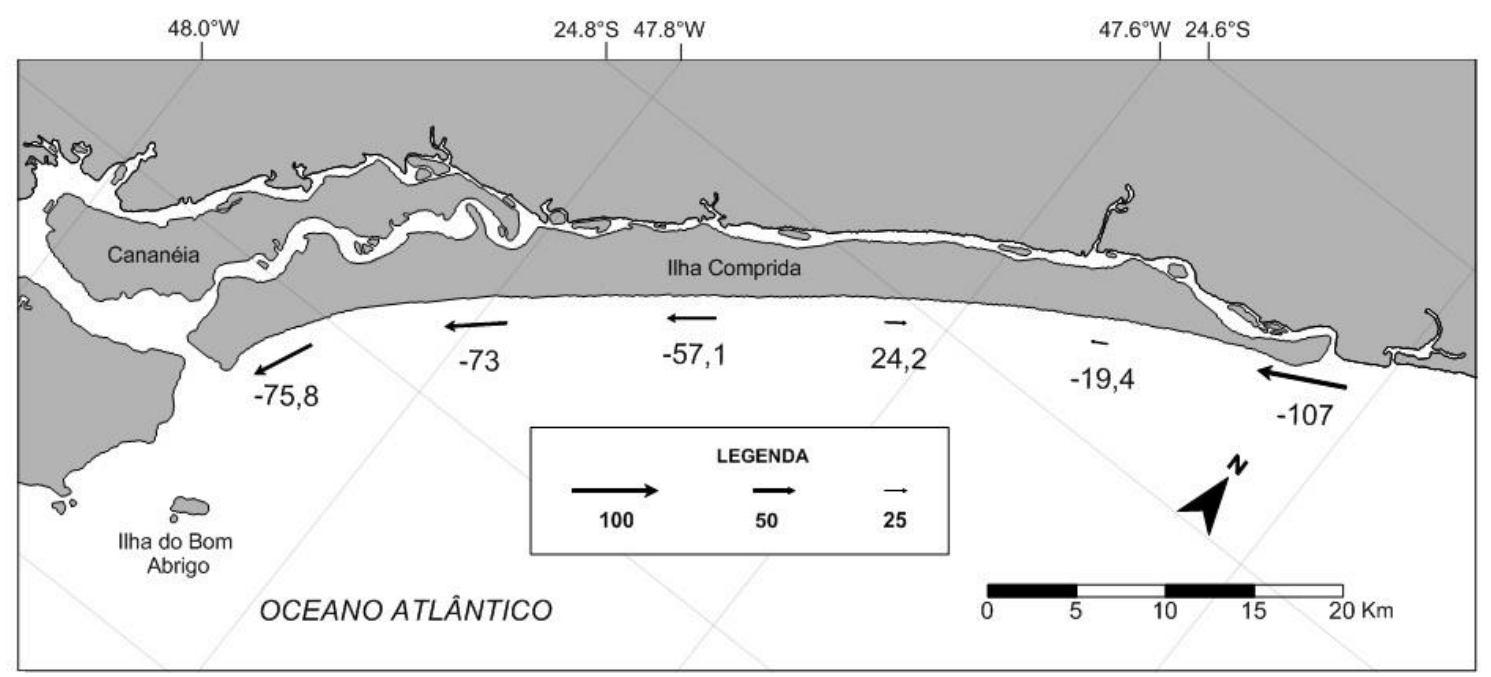

Figura 5.24: Distribuição da deriva potencial ao longo dos setores considerando o período D.

A semana anterior não apresentou nenhuma passagem de frente fria, com a deriva direcionada em sua totalidade para SW (Figura 5.25). Os maiores valores foram encontrados nos setores 1,3 e 5 com -904 , -764 e -747. Os pontos de divergência residual foram entre os trechos 5-4 e 3-2, sendo a primeira mais intensa, com valores aproximados em -100. Dentre os outros setores, onde foram reconhecidos padrões de convergência residual, o maior valor foi encontrado entre os trechos 2-1 e 6-5, com valores aproximados em $200 \mathrm{em}$ ambos. 


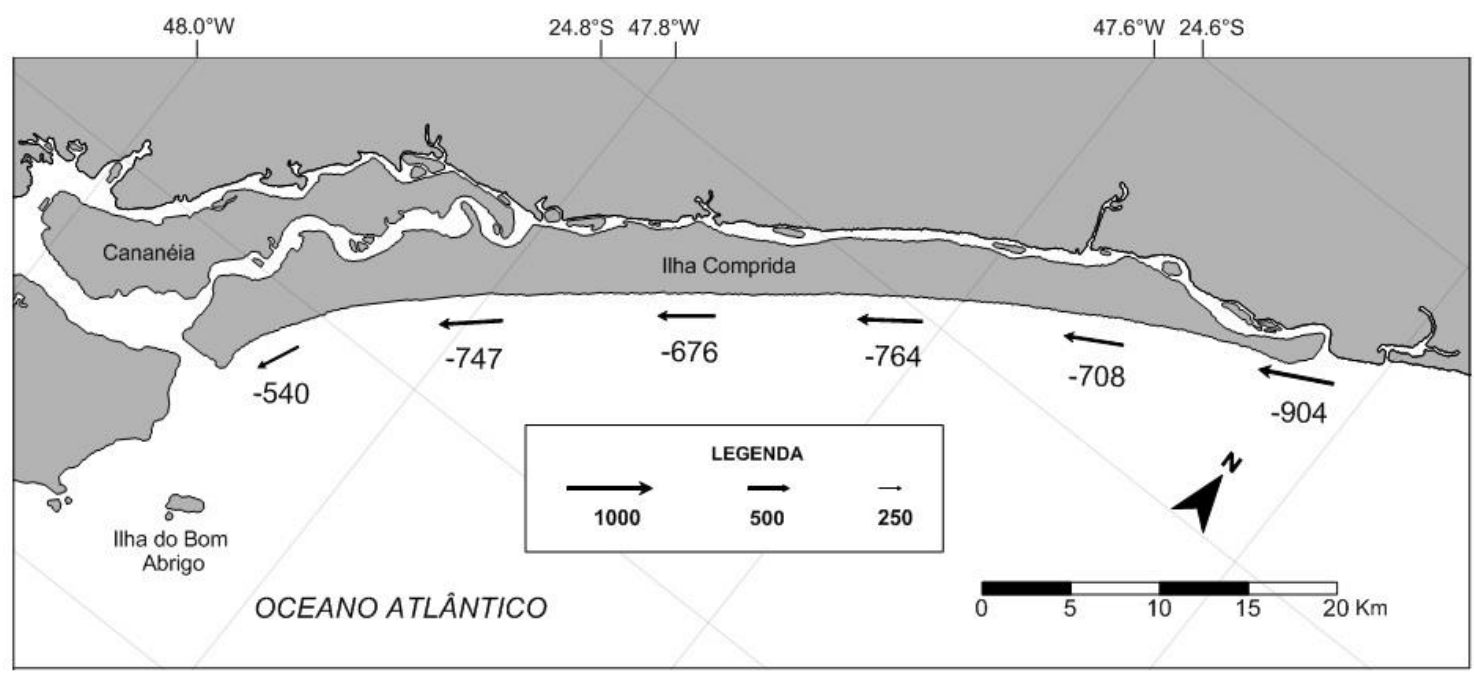

Figura 5.25: Distribuição da deriva potencial ao longo dos setores considerando apenas a última semana do período D.

O período $\mathrm{E}$ foi marcado pela manutenção da tendência de transporte para $\mathrm{SW}$, com valores de magnitude variando entre 120 e 500, aproximadamente. Os trechos com maior transporte longitudinal foram 1, 2 e 5 com, respectivamente, -501, -305 e -252. Centros de divergência residual foram reconhecidos entre os trechos 5-4 e 4-3, sendo o último mais eficiente em magnitude, alcançando valores próximos a -20. Em relação aos centros de convergência, o setor entre os trechos 2-1 apresentou-se mais expressivo que os outros, com cerca de 200 em magnitude (Figura 5.26).

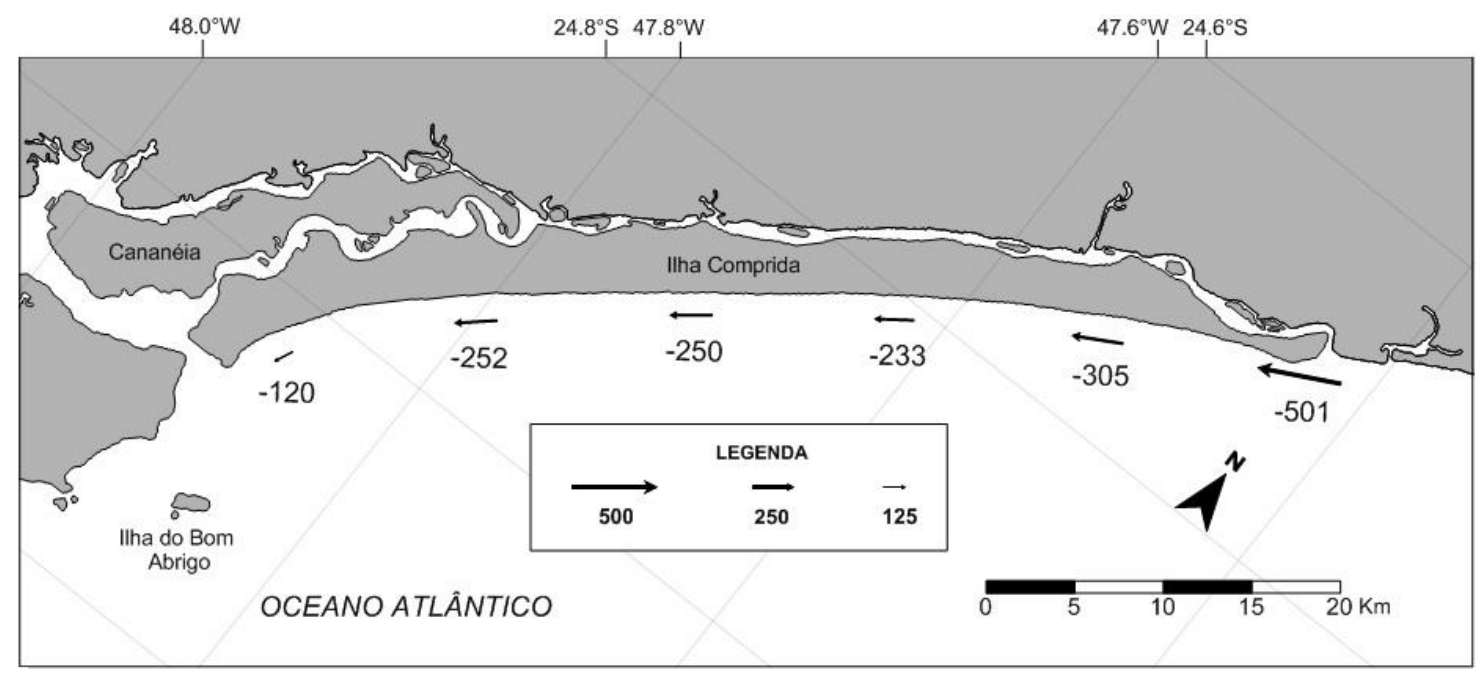

Figura 5.26: Distribuição da deriva potencial ao longo dos setores considerando o período E.

Em relação à semana anterior ao levantamento E, a qual apresentou a passagem de um sistema frontal cerca de 5 dias antes do campo, a deriva se mostrou condicionada 
para SW em todos os setores, sendo maior nos trechos 1, 2 e 4, com -929, -496 e -410. Apenas um centro de divergência foi reconhecido, estando situado entre o trecho 4-3 com magnitude de cerca de -80 . O centro de convergência com maior valor em magnitude também esteve situado entre os trechos 2-1, com valores próximos aos 500 (Figura 5.27).

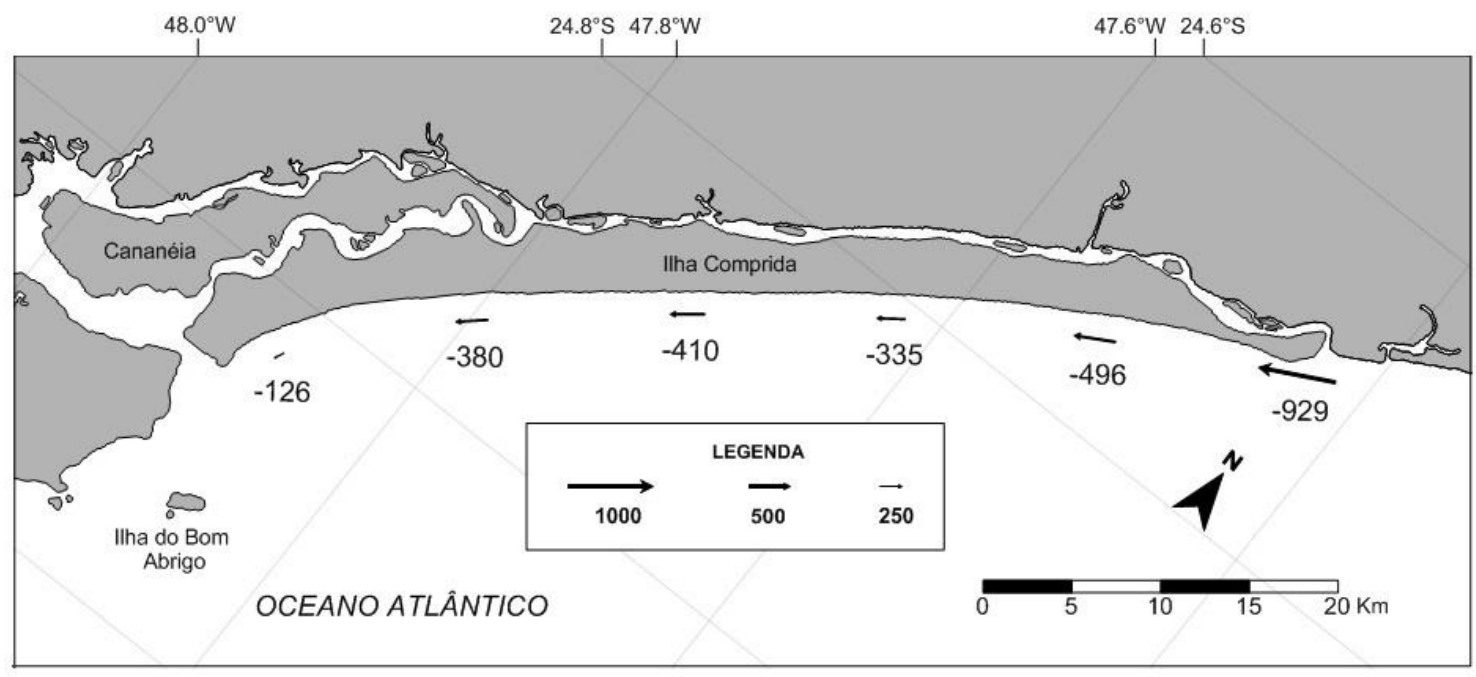

Figura 5.27: Distribuição da deriva potencial considerando apenas a última semana do período E.

Considerando os cinco períodos, é possível reconhecer dois padrões de tendência de transporte longitudinal, sendo a parte mais ao norte direcionado para SW e a parte mais ao sul direcionado para NE, enquanto que a porção central apresentou uma tendência de divergência direcional, gerando consequentemente dois centros de convergência nas regiões centro-sul e centro-norte. A ponta norte apresentou um setor de divergência similar aos encontrados nos padrões de tendência de longo termo, iniciando aproximadamente no quilometro 58 e se estendendo até o extremo norte. Outro pequeno setor de divergência residual pode ser reconhecido entre os quilômetros aproximados 5 e 10, na porção extremo sul. A divergência direcional do centro ocorre entre os limites aproximados de $32 \mathrm{~km}$ e $44 \mathrm{~km}$, possuindo uma extensão aproximada em $8 \mathrm{~km}$. 


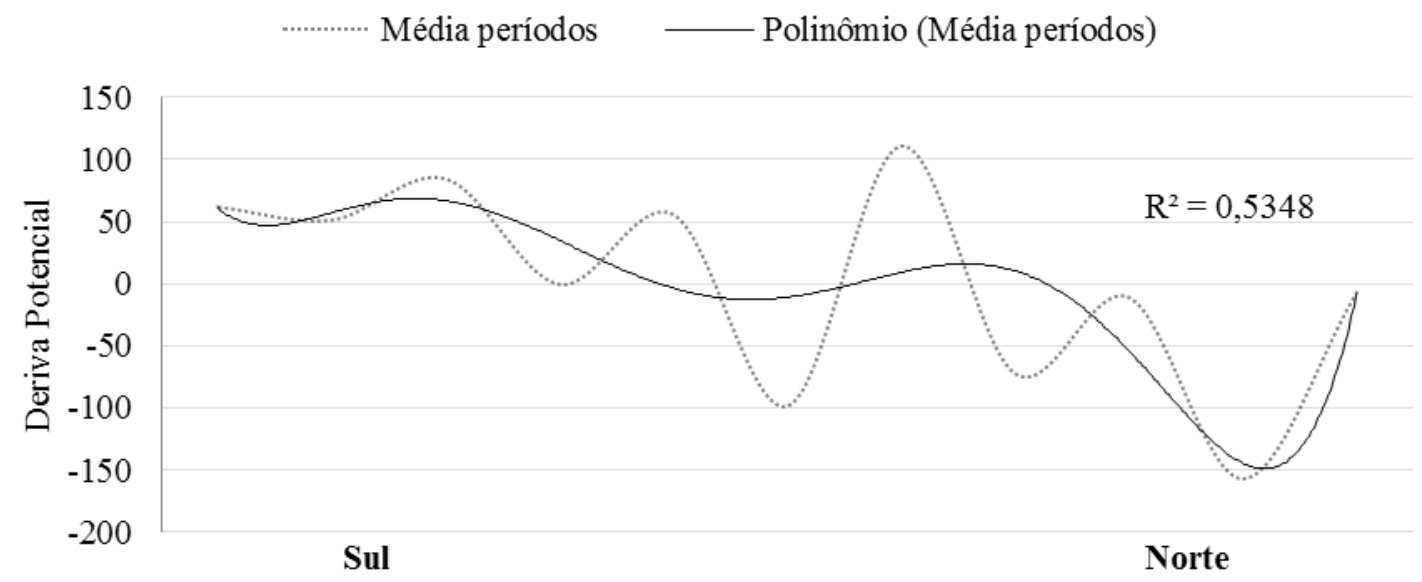

Figura 5.28: Deriva litorânea potencial média dos períodos analisados, com uma curva polinomial de tendência.

\subsubsection{Força de Onda}

Para analisar a força de onda para cada período, mapas de distribuição foram elaborados, tanto para o período inteiro quanto para a semana anterior ao levantamento. Para melhor comparação, procurou-se manter a mesma escala de cores, de modo a favorecer comparações temporais. Deste modo, cortes longitudinais foram acrescentados para cada mapa de distribuição, de modo a facilitar as comparações espaciais.

O período A foi caracterizado por uma distribuição de força de onda baixa, com valores variando entre 1,0 e $5,0.10^{5} \mathrm{~W} / \mathrm{m}$, sendo menores na porção sul se comparado com a porção norte (Figura 5.29). O pico de magnitude foi encontrado no extremo norte da ilha, enquanto que o mínimo de energia foi encontrado entre o quilometro 5 e 8 , próximos ao extremo sul. A Figura 5.30 mostra os valores para a semana que antecedeu o levantamento, alcançando valores entre 1,0 e 4,0.10 $\mathrm{W} / \mathrm{m}$. Estes valores são menores que os estimados para o período inteiro, mas com baixa diferença em magnitude. Além disso, há uma tendência de crescimento para NE, com uma leve estabilização do crescimento na porção central da ilha (Figura 5.31). 


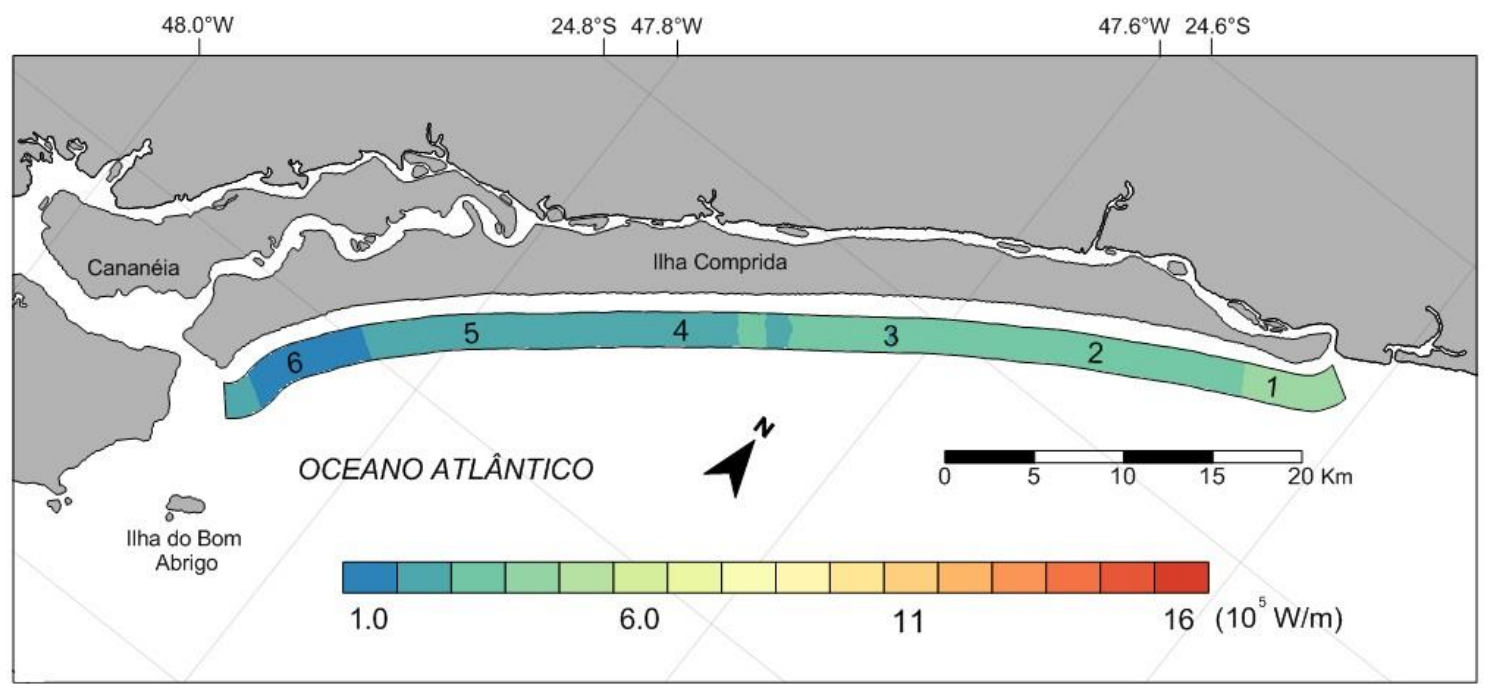

Figura 5.29: Distribuição de força de onda ao longo da costa da Ilha Comprida para o período A.

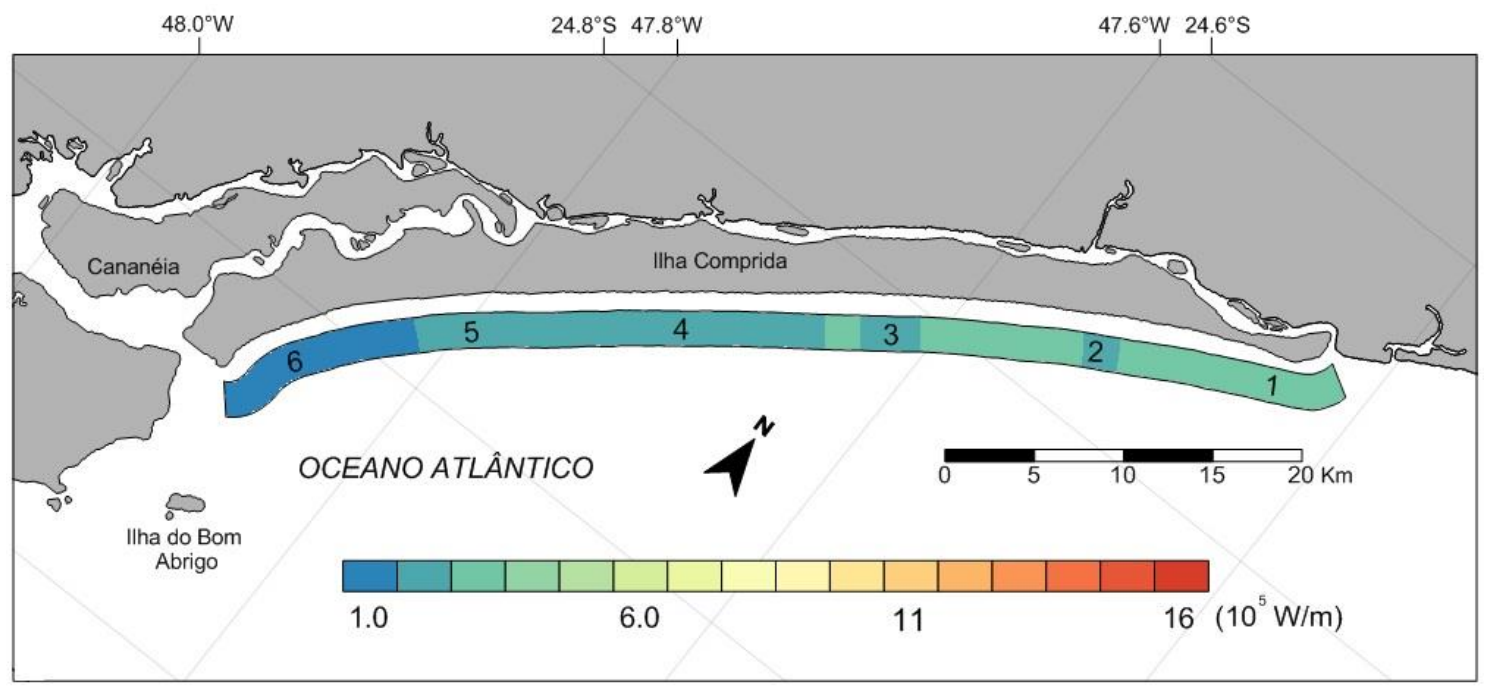

Figura 5.30: Distribuição de força de onda ao longo da costa da Ilha Comprida para a última semana do período A.
A (Total)
A (Semana)

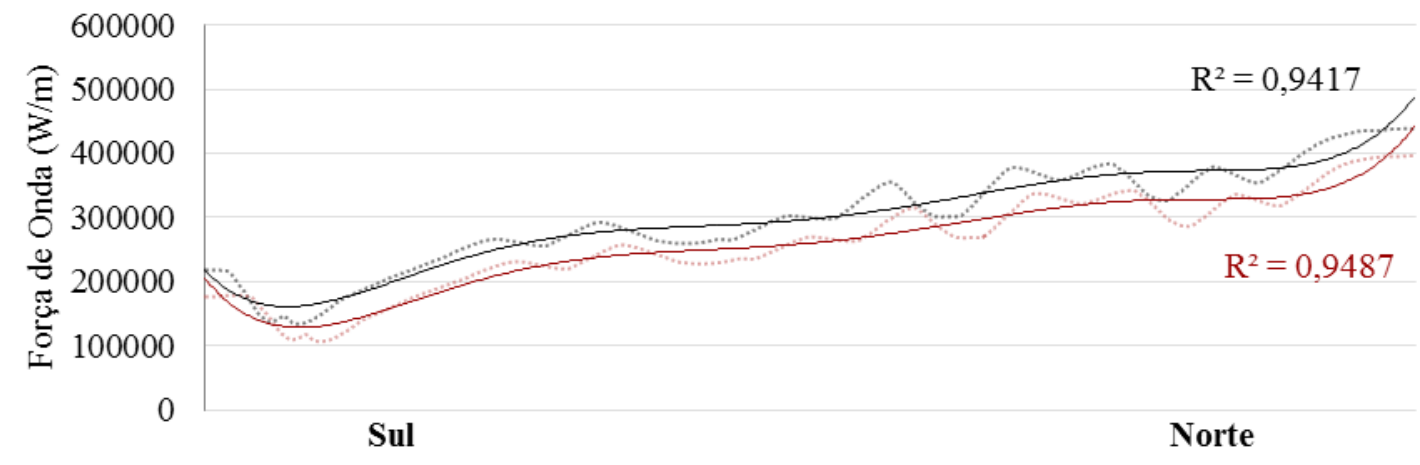

Figura 5.31: Variação longitudinal da força de onda para o período A inteiro e para a última semana, com suas curvas polinomiais de tendência. 
O período B foi caracterizado por uma distribuição de força de onda maior quando comparada com o período precedente, com valores variando entre 3,5 e 8,5.10 $\mathrm{W} / \mathrm{m}$, sendo também menores na porção sul se comparado com a porção norte (Figura 5.32). A distribuição espacial da energia, entretanto, se mostrou similar, com o pico de magnitude encontrado no extremo norte da ilha, enquanto que o mínimo de energia foi encontrado também entre o quilometro 5 e 8, próximos ao extremo sul (Figura 5.34). A semana que antecedeu o levantamento apresentou valores abaixo destes médios para o período inteiro, mas com relativa diferença em magnitude, alcançando valores entre 3,0 e $5,5.10^{5} \mathrm{~W} / \mathrm{m}$ (Figura 5.33).

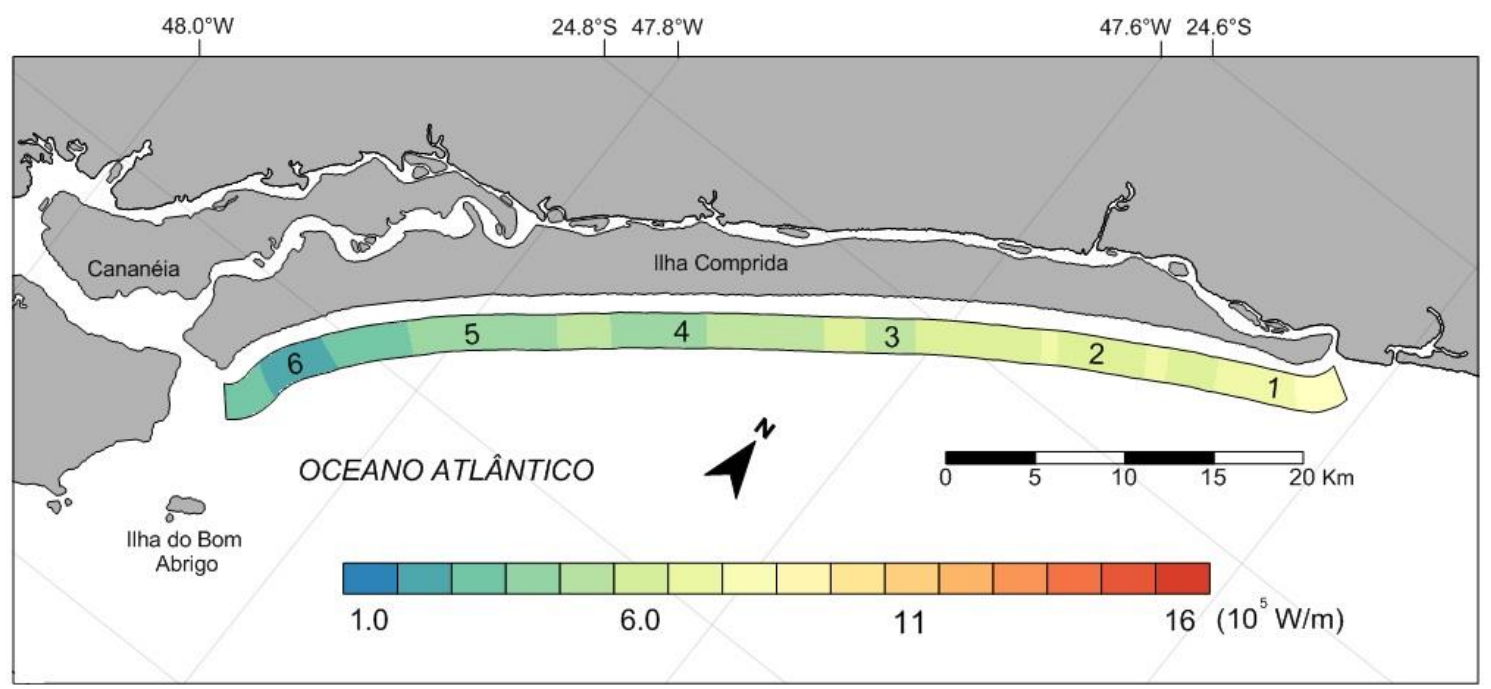

Figura 5.32: Distribuição de força de onda ao longo da costa da Ilha Comprida para o período B.

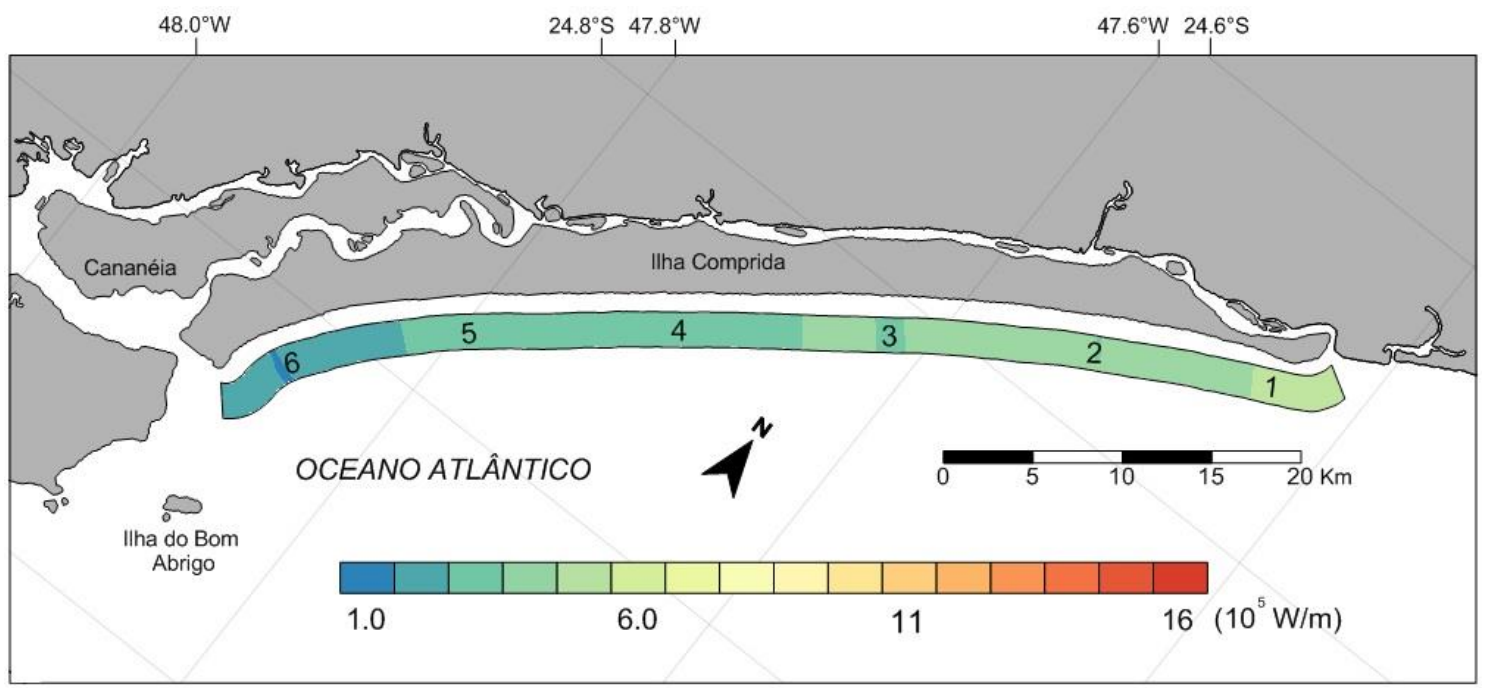

Figura 5.33: Distribuição de força de onda ao longo da costa da Ilha Comprida para a última semana do período B. 


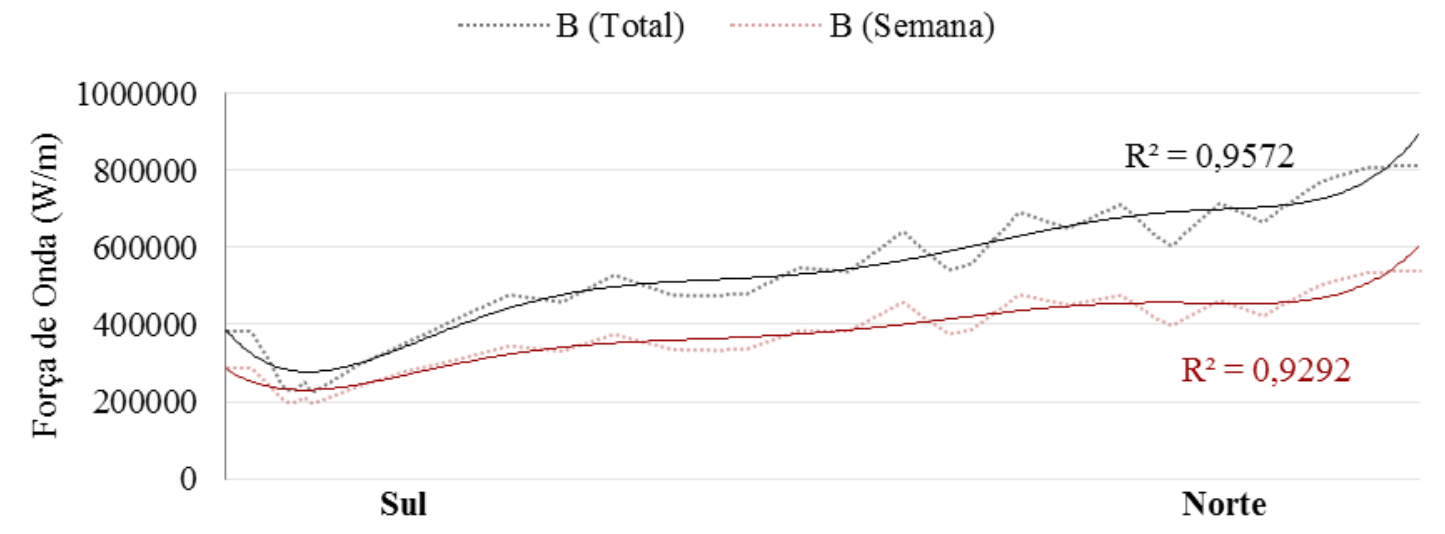

Figura 5.34: Variação longitudinal de força de onda para o período B e sua última semana, com suas curvas polinomiais de tendência.

$\mathrm{O}$ período $\mathrm{C}$ foi caracterizado por uma distribuição de força de onda similar quando comparada com o período A, com valores variando entre 1,0 e $5,0.10^{5} \mathrm{~W} / \mathrm{m}$, sendo também menores na porção sul se comparado com a porção norte (Figura 5.35). A distribuição espacial da energia, entretanto, se mostrou similar aos períodos A e B, com o pico de magnitude encontrado no extremo norte da ilha, enquanto que o mínimo de energia foi encontrado também entre o quilometro 5 e 8, próximos ao extremo sul. A semana que antecedeu o levantamento apresentou valores superiores destes para o período inteiro, alcançando valores entre 5,0 e 15,0.10 $\mathrm{W} / \mathrm{m}$ (Figura 5.36). Esta semana foi caracterizada pela entrada de uma frente fria, o que evidencia os maiores valores. É importante frisar que esta entrada de ondas energéticas aumentou muito mais significativamente a energia incidente na ponta norte quando comparada a ponta sul (Figura 5.37).

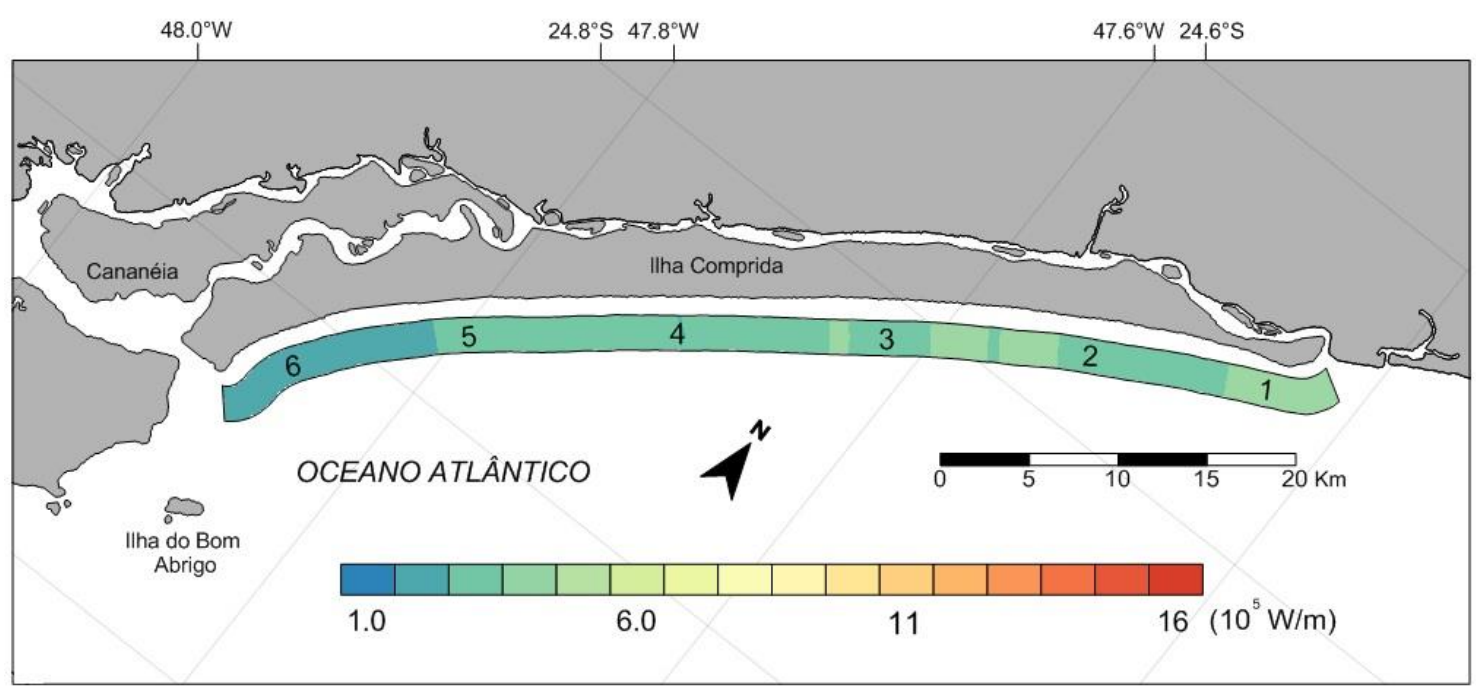

Figura 5.35: Distribuição de força de onda ao longo da costa da Ilha Comprida para o período C. 


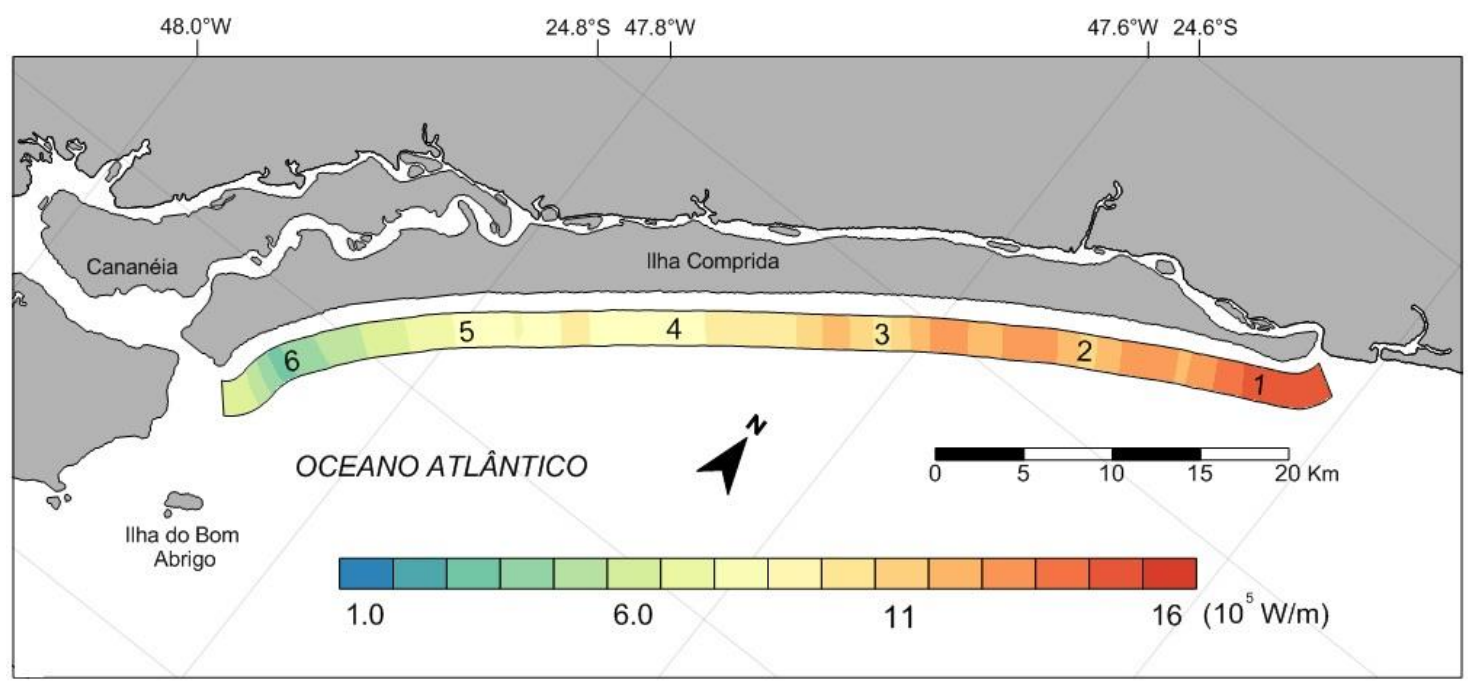

Figura 5.36: Distribuição de força de onda ao longo da costa da Ilha Comprida para a última semana do período C.

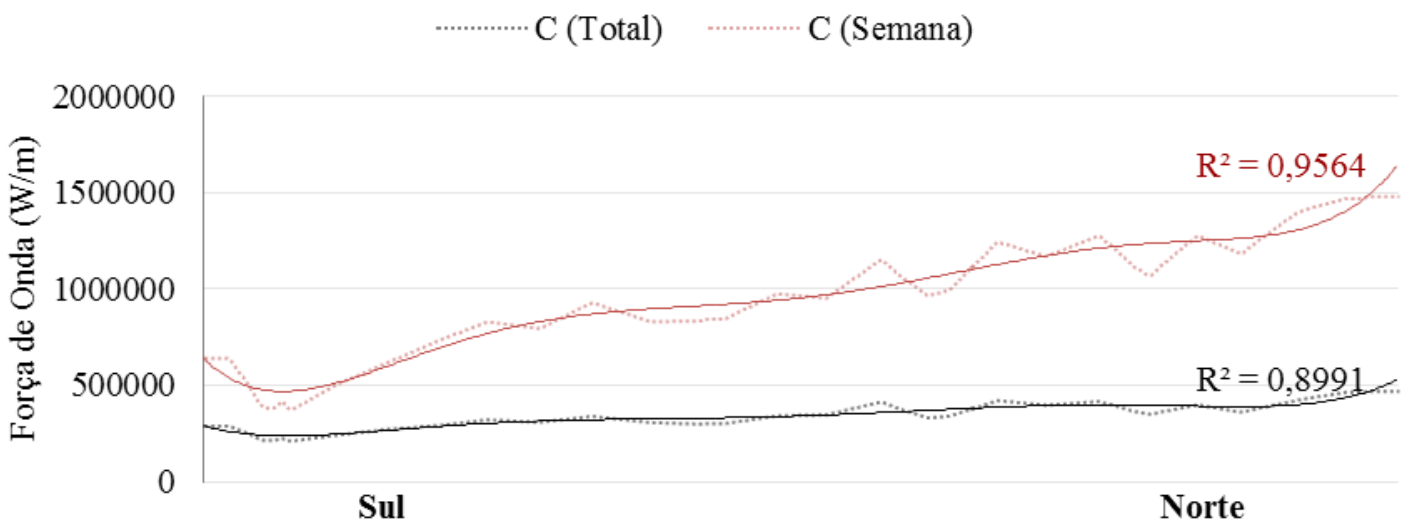

Figura 5.37: Variação longitudinal de força de onda para o período $\mathrm{C}$ e sua última semana, com suas respectivas curvas polinomiais de tendência.

O período D foi caracterizado por uma distribuição de força de onda amena quando comparada com o período anterior, com valores variando entre 1,0 e 3,0.10 W/m, sendo também menores na porção sul se comparado com a porção norte (Figura 5.38). A distribuição espacial da energia, entretanto, se mostrou similar, com o pico de magnitude encontrado no extremo norte da ilha, enquanto que o mínimo de energia foi encontrado também entre o quilometro 5 e 8, como nos períodos anteriores. A semana que antecedeu o levantamento apresentou valores inferiores destes para o período inteiro, alcançando valores entre 1,0 e 1,5.10 $5 / \mathrm{m}$ (Figura 5.39). É importante salientar que, nesta semana, a distribuição espacial mostrou uma variação, estando a força de onda relativamente constante em magnitude ao longo de toda a costa da ilha, com um pequeno aumento na ponta norte (Figura 5.40). 


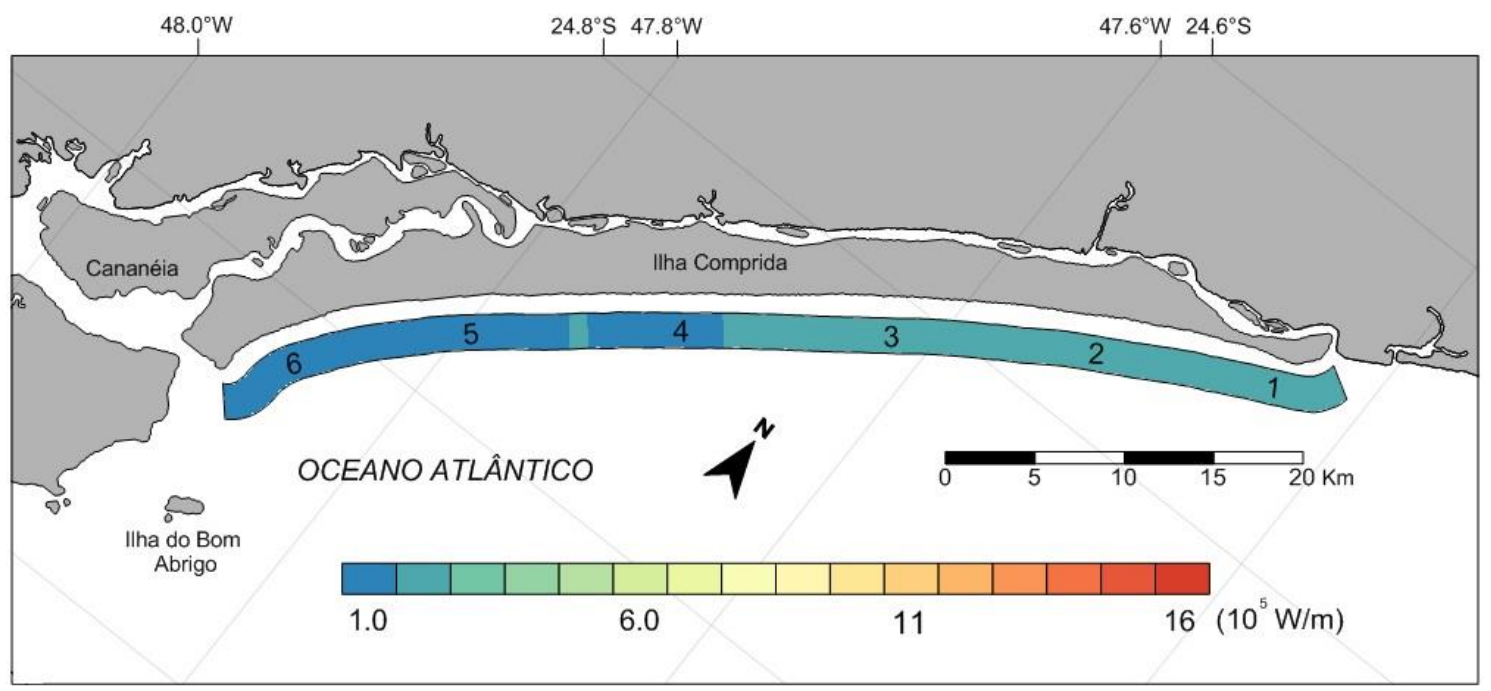

Figura 5.38: Distribuição de força de onda ao longo da costa da Ilha Comprida para o período D.

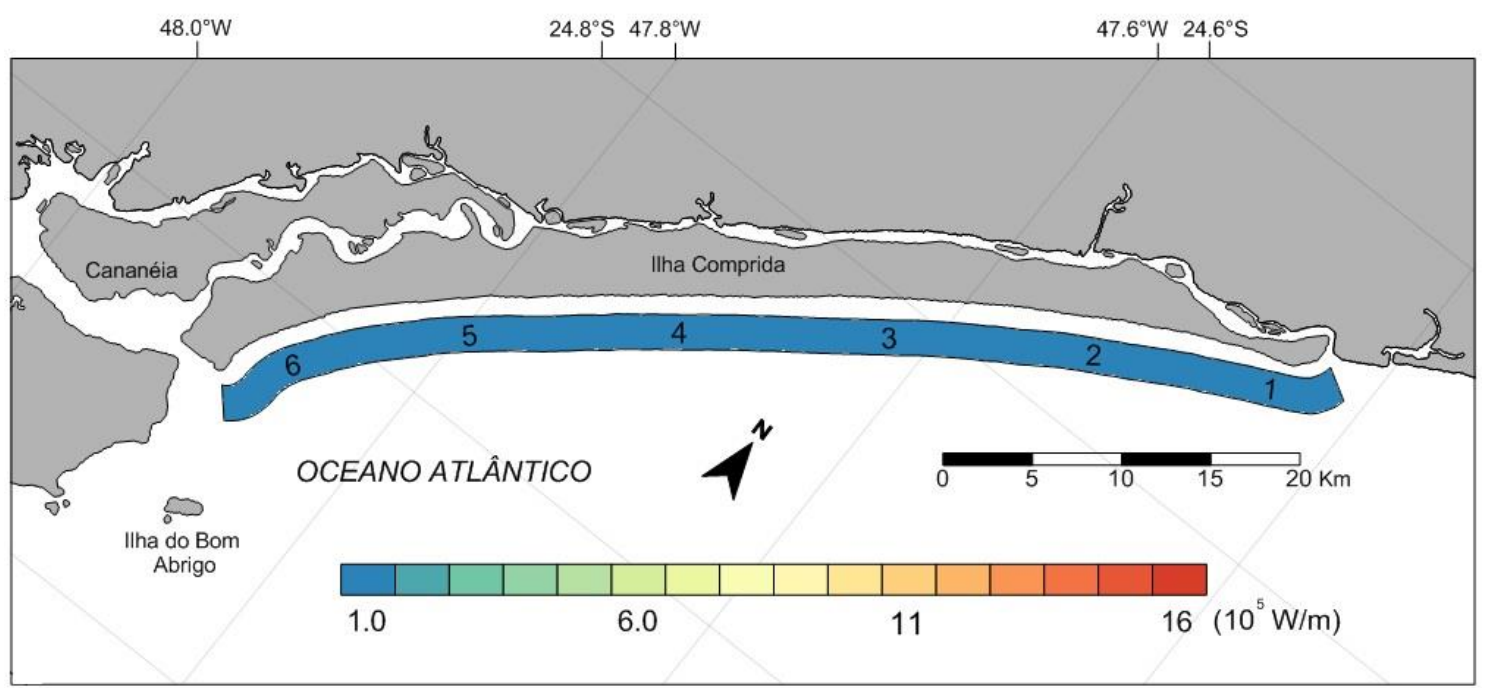

Figura 5.39: Distribuição de força de onda ao longo da costa da Ilha Comprida para a última semana do período D.
D (Total)
D (Semana)

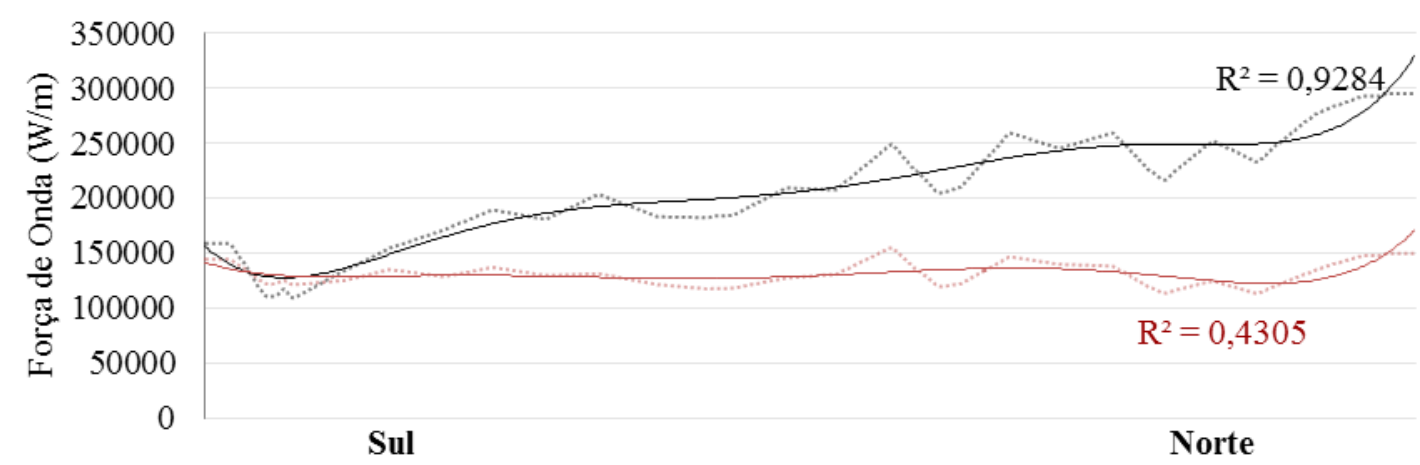

Figura 5.40: Variação longitudinal de força de onda para o período $D$ e sua última semana, com suas respectivas curvas polinomiais de tendência. Importante frisar o baixo $\mathrm{r}^{2}$ para a curva referente a última semana. 
O período E foi caracterizado por uma distribuição de força de onda similar ao período anterior, com valores variando entre 1,0 e $3,0.10^{5} \mathrm{~W} / \mathrm{m}$, sendo também menores na porção sul se comparado com a porção norte (Figura 5.41). A distribuição espacial da energia, entretanto, se mostrou similar, com o pico de magnitude encontrado no extremo norte da ilha, enquanto que o mínimo de energia foi encontrado também entre o quilometro 5 e 8, próximos ao extremo sul (Figura 5.43). A semana que antecedeu o levantamento apresentou valores superiores destes para o período inteiro, alcançando valores entre 3,0 e 7,0.10 $\mathrm{W} / \mathrm{m}$, com distribuição espacial com tendência de aumento em direção a ponta norte da ilha (Figura 5.42).

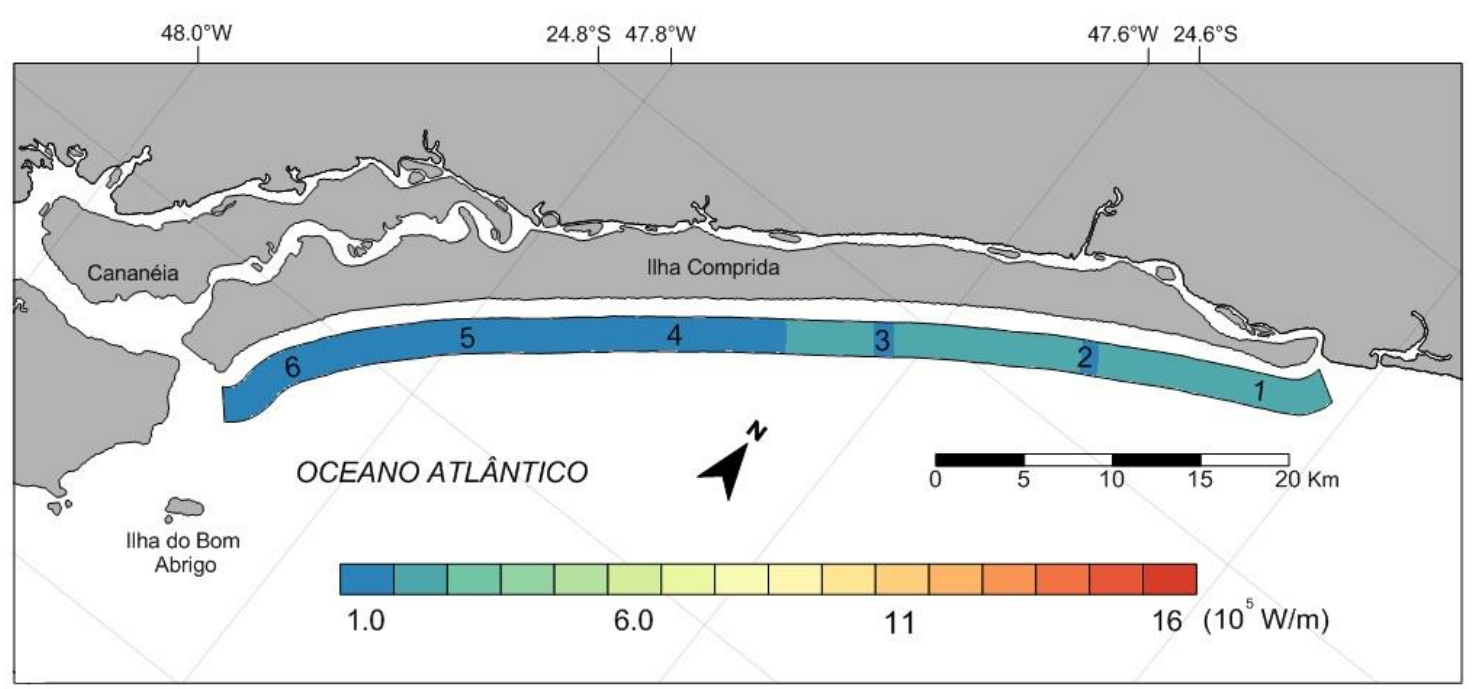

Figura 5.41: Distribuição de força de onda ao longo da costa da Ilha Comprida para o período E.

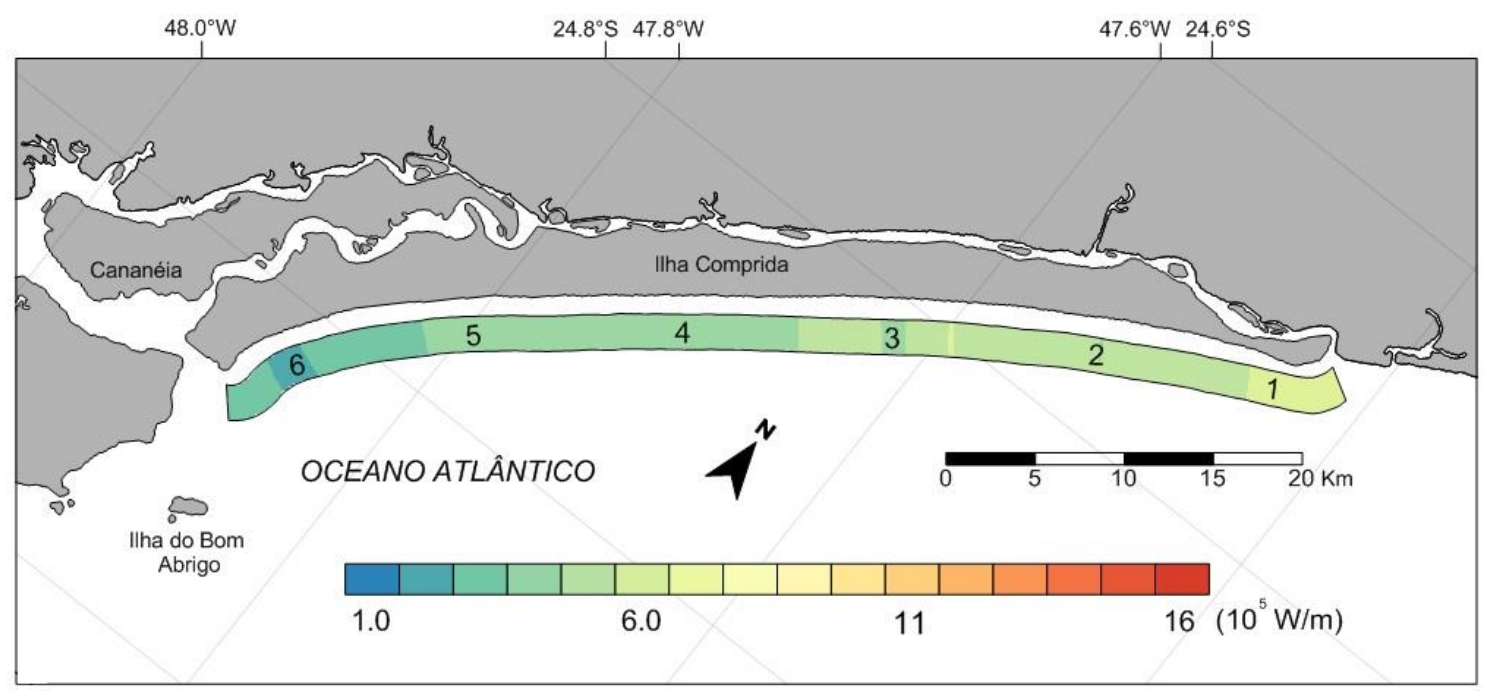

Figura 5.42: Distribuição de força de onda ao longo da costa da Ilha Comprida para a última semana do período E. 


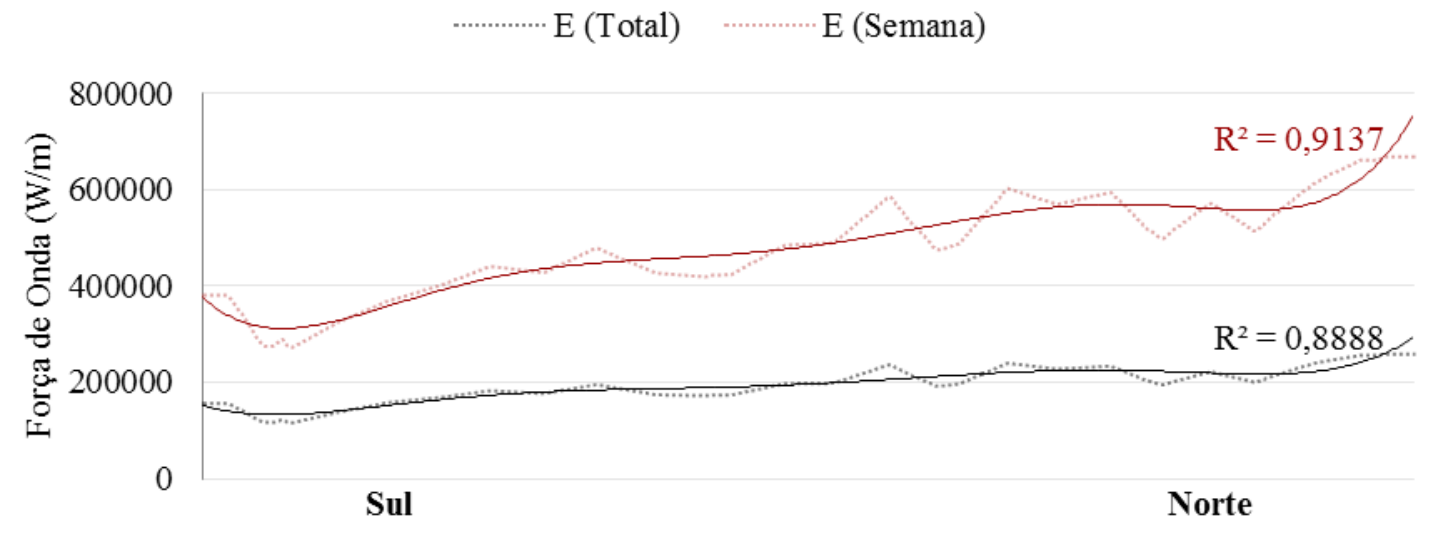

Figura 5.43: Variação longitudinal de força de onda para o período E e sua semana, com suas respectivas curvas polinomiais de tendência.

\subsubsection{Dinâmica praial}

\subsubsection{Caracterização dos setores}

O Caminhamento 1, abreviado aqui como $\mathrm{C} 1$, é o trecho mais setentrional dentre os cinco analisados. Está localizado aproximadamente a uma distância de 58 quilômetros com referencial na ponta sul da Ilha Comprida, com um azimute aproximado em 60 graus (Figura 5.44). Está é uma região caracterizada por apresentarse aberta a incidência de ondas de todos os quadrantes, bem como por uma escarpa de erosão ativa na zona do pós-praia. Em relação à associação morfológica do sistema praia-duna, esta região é caracterizada por Nascimento (2006) como em transição entre um domínio de terraço de dunas frontais incipientes em praia com franja eólica e de nebkhas isolados sobre terraço recoberto por franja eólica, em praia intermediária a dissipativa. Além disso, esta região é marcada por dois aspectos: a presença de um pequeno campo de dunas de baixa altura na região adjacente ao pós-praia (Figura 5.45) e de um processo erosivo intenso (Figura 5.46). 


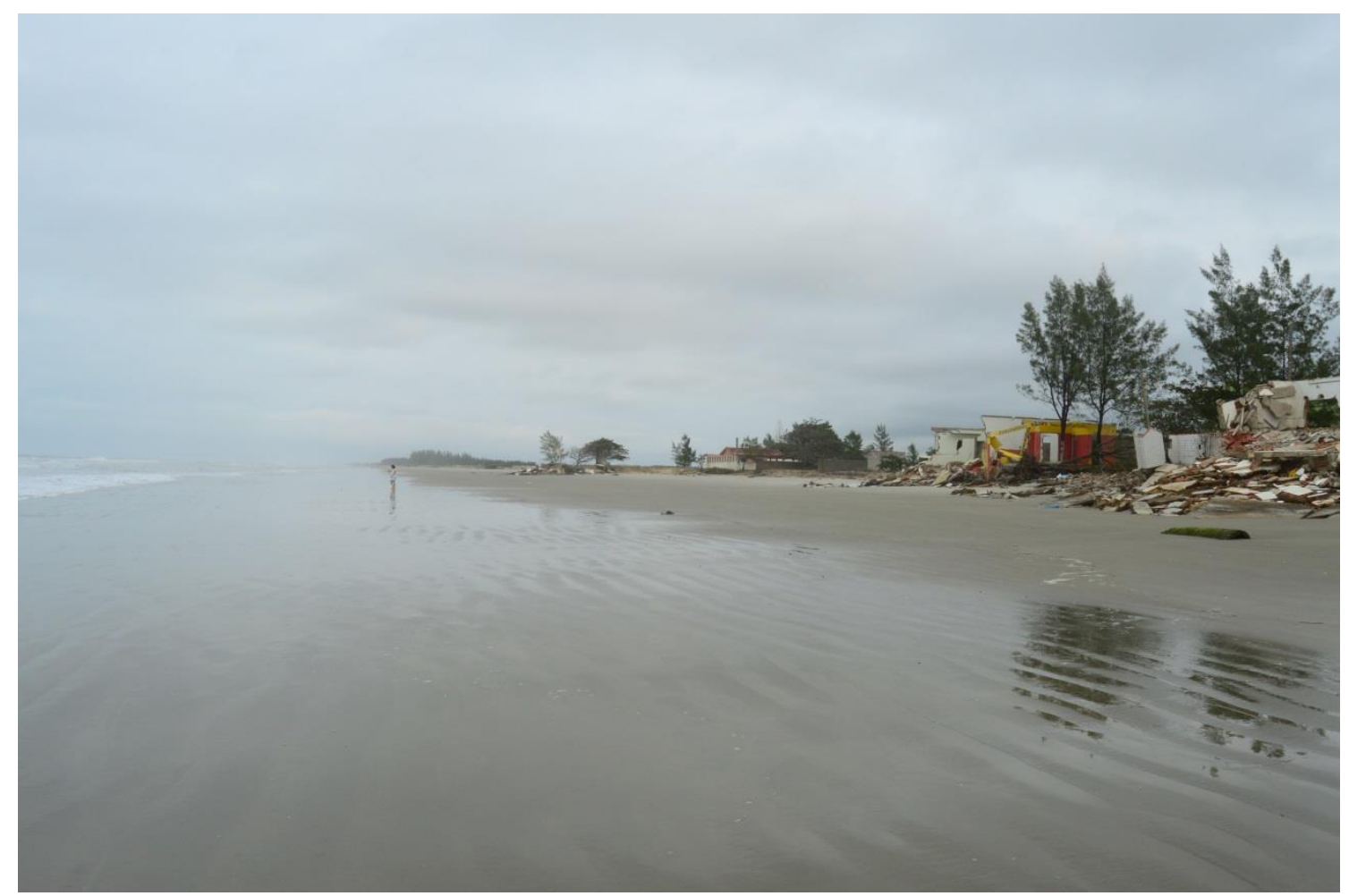

Figura 5.44: Imagem da ponta norte do Caminhamento 1 monitorado.

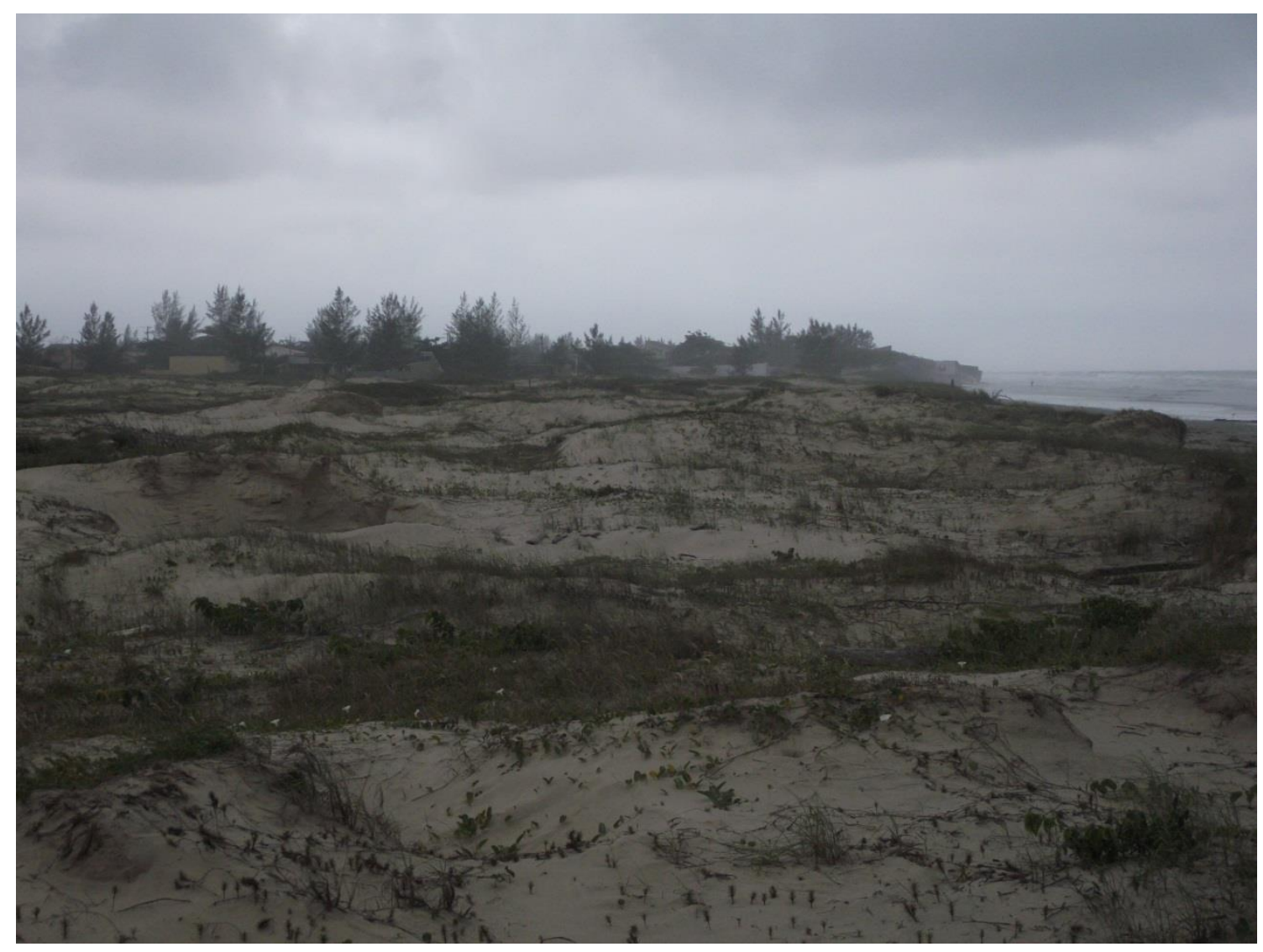

Figura 5.45: Pequeno campo de dunas adjacente à região sul do Caminhamento. 


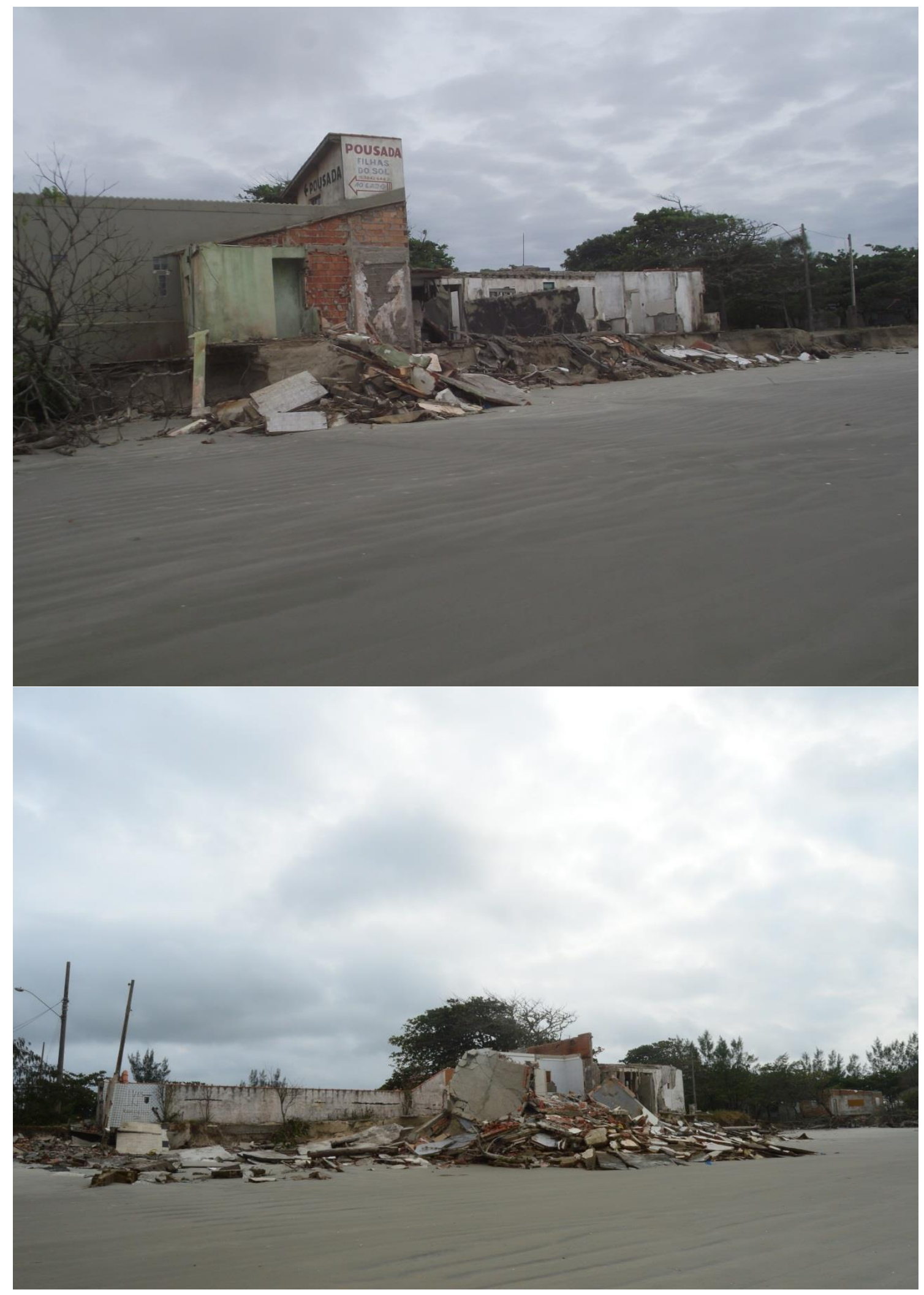

Figura 5.46: Foto de construção em fev/13 (acima) e maio/14 (abaixo), evidenciando o grau de recuo da região.

O Caminhamento 2, abreviado por $\mathrm{C} 2$, é caracterizado por situar-se na região mais urbana da Ilha Comprida, na região norte do sistema. Situa-se no quilometro 47, 
sendo o referencial zero a ponta sul da Ilha Comprida, possuindo um azimute aproximado em 56 graus. Segundo Nascimento (2006), é uma região de praia dissipativa, caracterizada por cordões de dunas frontais, uma franja eólica e uma face praial ampla (Figura 5.47). A estrada beira-mar mantém uma distância de cerca de 150 metros em relação à duna frontal da região, sendo esta distância preenchida por tais cordões mais antigos.

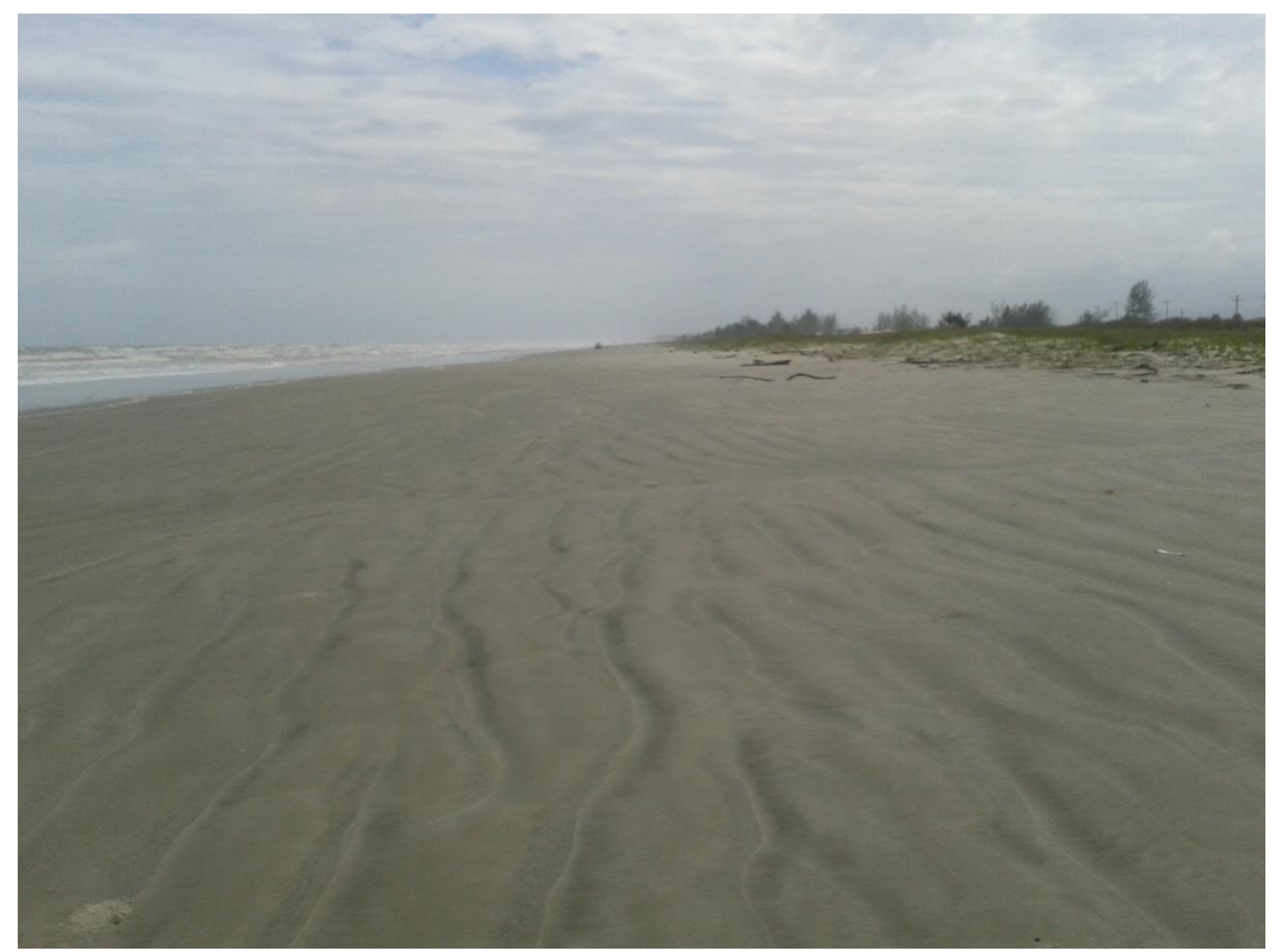

Figura 5.47: Imagem do Caminhamento 2, na porção mais ocupada da ilha.

O Caminhamento 4, abreviado por C4, está situado aproximadamente na região central da ilha, localizado aproximadamente no quilometro 31, com o zero referenciado na ponta sul. Possui um azimute aproximado de 49 graus, sendo caracterizado por uma larga faixa de praia, com uma duna frontal bem definida, sendo caracterizada por Nascimento (2006) como uma região de praias dissipativas, com franja eólica e cordões (Figura 5.48). É uma região aberta à incidência de ondas de todos os quadrantes, sendo que, apesar de menos afetada em relação a urbanização quando comparada com $\mathrm{C} 1 \mathrm{e}$ C2, a pista adjacente composta de terra batida se encontra a 50 metros aproximadamente da duna frontal. 


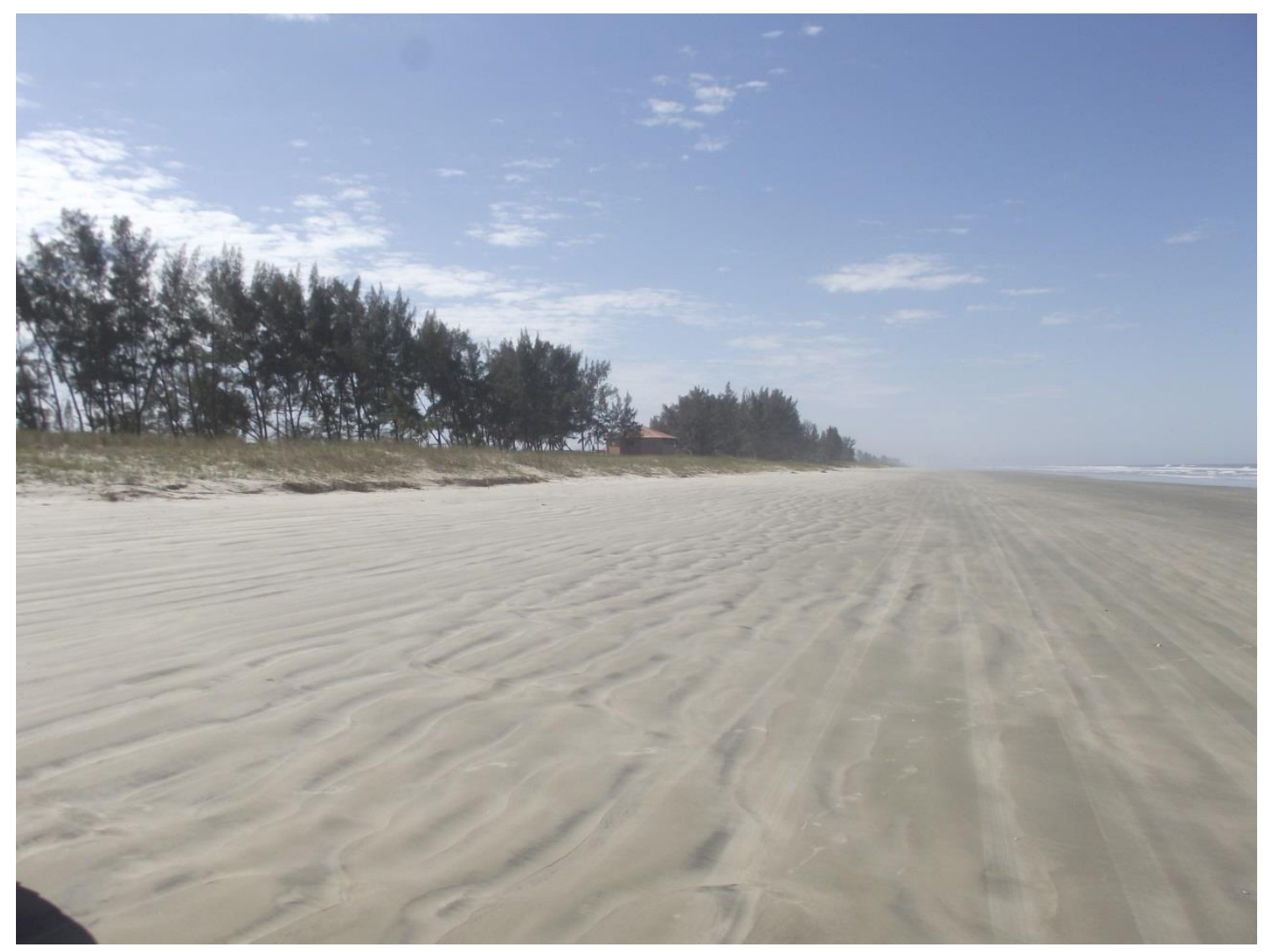

Figura 5.48: Imagem do Caminhamento 3, na região central da ilha.

O Caminhamento 5, abreviado por C5, está situado na região centro-sul da ilha, localizado aproximadamente no quilometro 14, com o zero referenciado na ponta sul. Possui um azimute aproximado de 44 graus, sendo caracterizada por Nascimento (2006) como uma região de praias dissipativas a intermediárias, com rampa de duna frontal incipiente sobre uma escarpa de duna estabelecida. É uma região aberta à incidência de ondas de todos os quadrantes, sem apresentar urbanização próxima (Figura 5.49). Esta região é denotada como atingida pela erosão evidenciada na região centro-sul tanto por Nascimento (op.cit.) quanto por Souza \& Suguio (1996). 


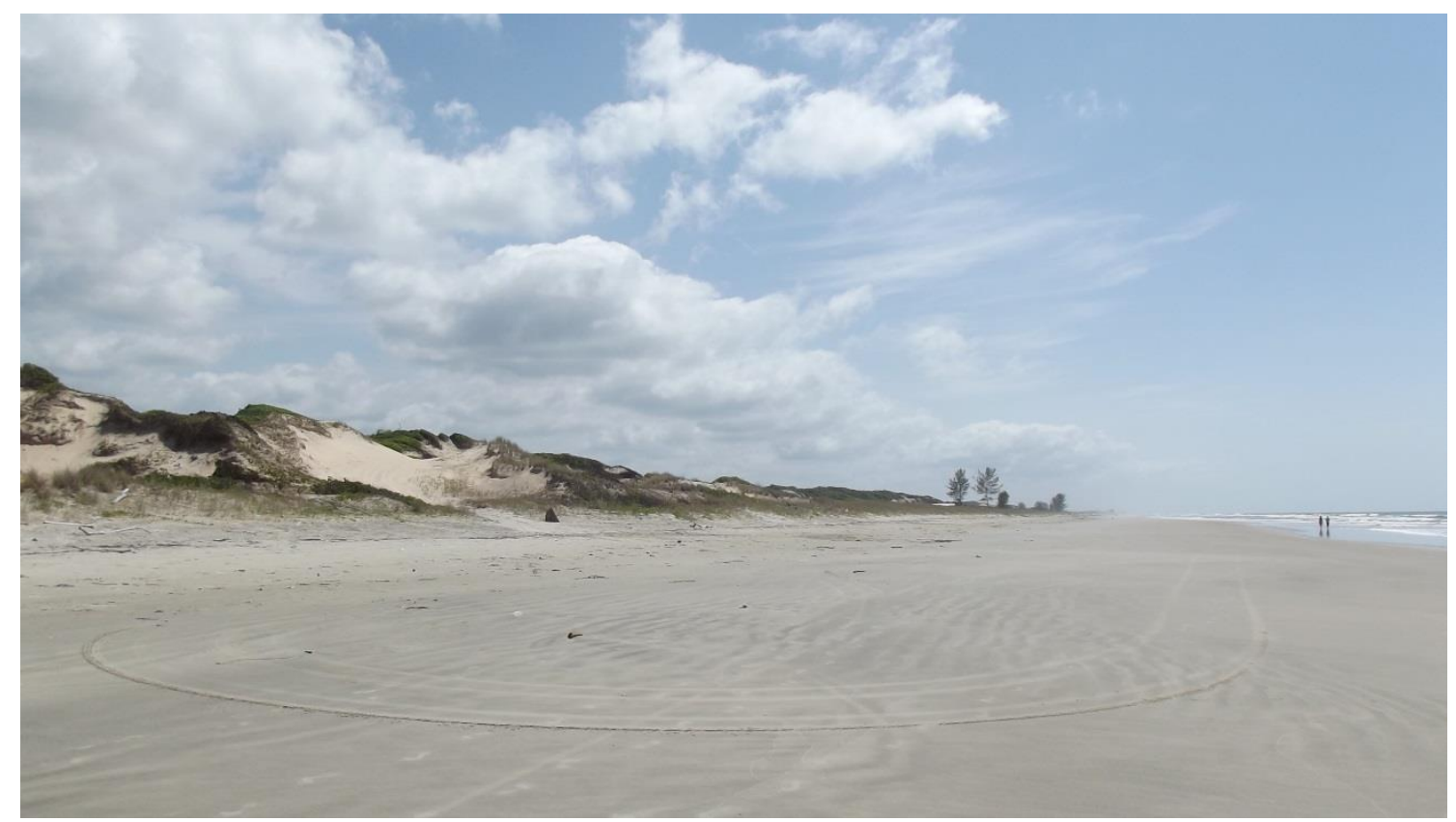

Figura 5.49: Imagem da face praial do Caminhamento 4, região centro-sul da ilha.

O Caminhamento 6, abreviado por C6, está situado na região sul da ilha, localizado aproximadamente no quilometro 3, com o zero referenciado na ponta sul. Possui um azimute aproximado de 21 graus, sendo caracterizada por Nascimento (2006) como uma região de praias dissipativas a intermediárias, com nebkhas isolados sobre terraço recoberto por franja eólica. É uma região aberta à incidência de ondas de quase todos os quadrantes, com exceção de ondulações de SW-S, que podem sofrer influência pela presença da ilha do Bom Abrigo e do delta de maré vazante da desembocadura de Cananéia. Está região foi estudada por Gagliardi (2013), Sousa (2013) e Marquez (2007), sendo relativamente bem conhecida e com grande acervo para comparação (Figura 5.50). 


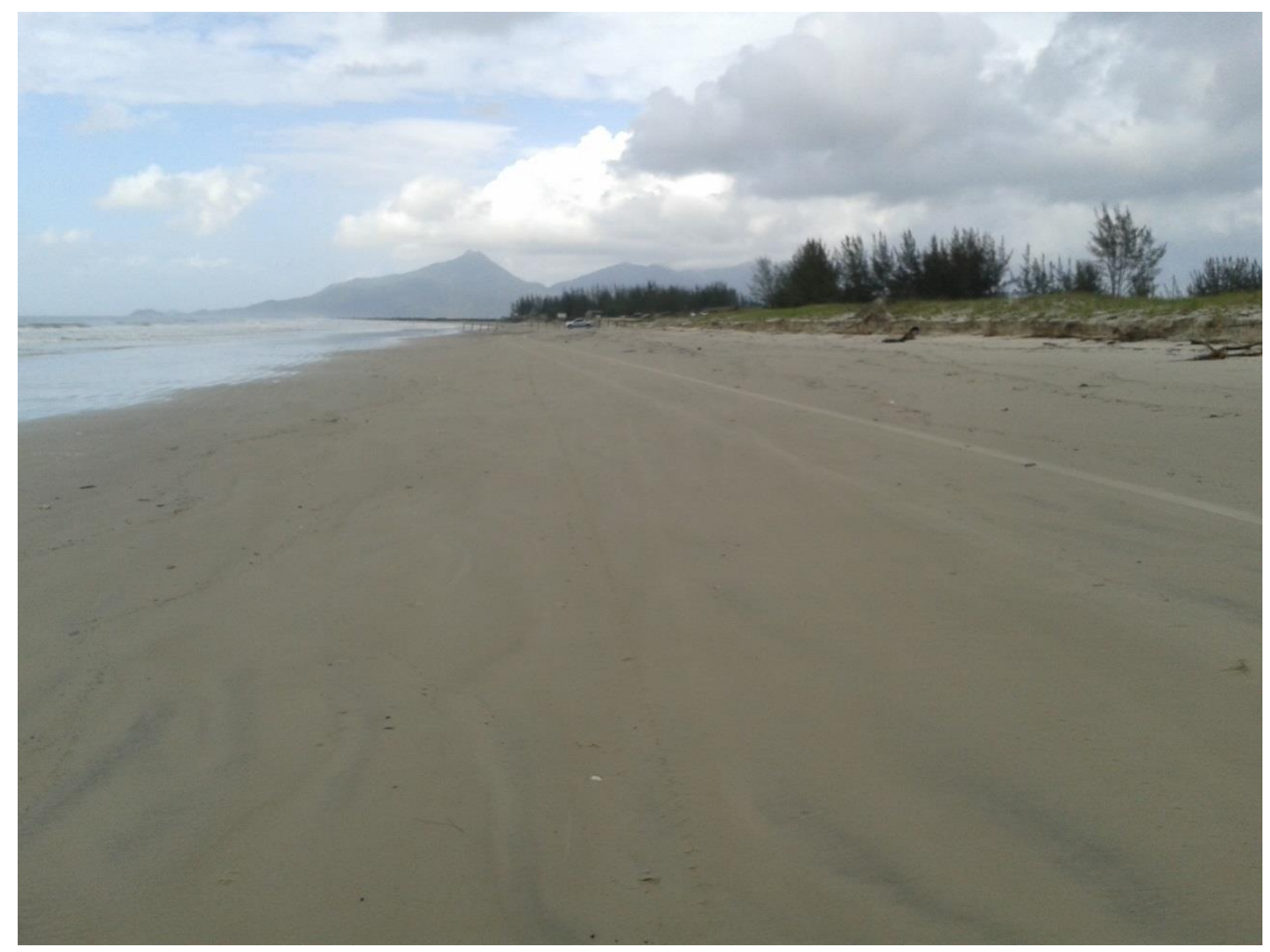

Figura 5.50: Imagem do Caminhamento 5, região sul da ilha.

\subsubsection{Variabilidade granulométrica}

Os parâmetros estatísticos para as amostras de sedimentos estão representados no Anexo 1. A distribuição sedimentar ao longo dos cinco setores mostrou predominância de areias finas, bem selecionadas, aproximadamente simétricas e mesocúrticas. Os valores de carbonato apresentaram valores médios de 1,06\% e desvio padrão de $0,8 \%$, aproximadamente, atingindo o valor máximo de 5,5\%, no Caminhamento 6, extremo sul da ilha, na antepraia durante o levantamento E. Os sedimentos presentes no pós-praia e face praial apresentaram valores similares de tamanho de grão, apresentando médias de 2,52 e 2,56 phi e desvio padrão de 0,2, enquanto que a antepraia apresentou valores médios de 2,34 phi, e desvio padrão de 0,26 .

Temporalmente, os sedimentos não mostraram significativa variação em cada setor em relação aos parâmetros estatísticos analisados, apresentando maior desvio padrão no Caminhamento 6 , com 0,28 phi e menores valores no Caminhamento 1 , com valores de 0,06 (Tabela 5.6). Todavia, é possível reconhecer uma variabilidade espacial 
dos valores de diâmetro médio e grau de seleção, com uma tendência de diminuição do grão e aumento do selecionamento do grão em direção ao Caminhamento 1, na ponta norte da ilha, evidenciada no compartimento antepraia. (Figura 5.51 e 5.52).

Tabela 5.6: valores médios e desvio padrão do diametro médio e grau de seleção, separados por trecho. Valores em phi

\begin{tabular}{ccccc}
\hline Caminhamento & \multicolumn{2}{c}{ Diâmetro médio } & \multicolumn{2}{c}{ Grau de Seleção } \\
\hline & Média & Desvio Padrão & Média & Desvio Padrão \\
C1 & 2,67 & 0,06 & 0,39 & 0,04 \\
C2 & 2,69 & 0,09 & 0,39 & 0,02 \\
C4 & 2,48 & 0,13 & 0,43 & 0,04 \\
C5 & 2,22 & 0,15 & 0,46 & 0,07 \\
C6 & 2,25 & 0,28 & 0,48 & 0,10 \\
\hline
\end{tabular}

\section{Pós-Praia}

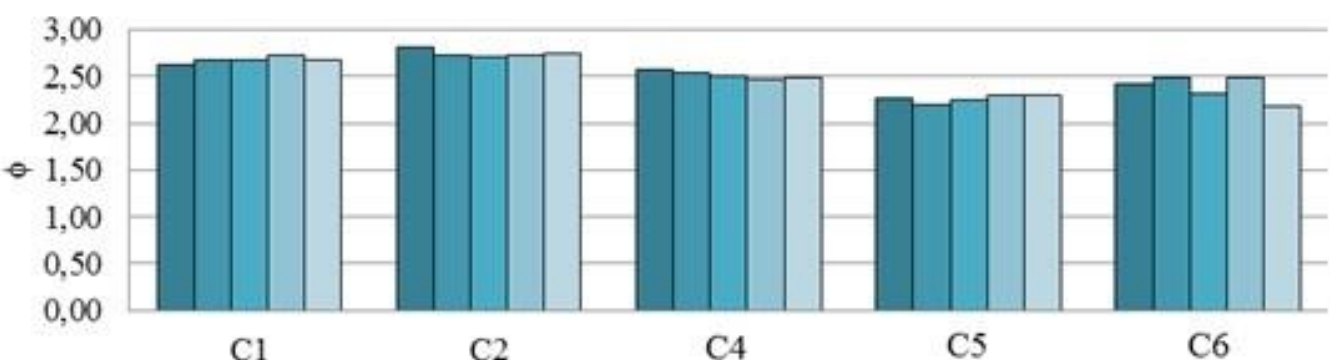

Face Praial

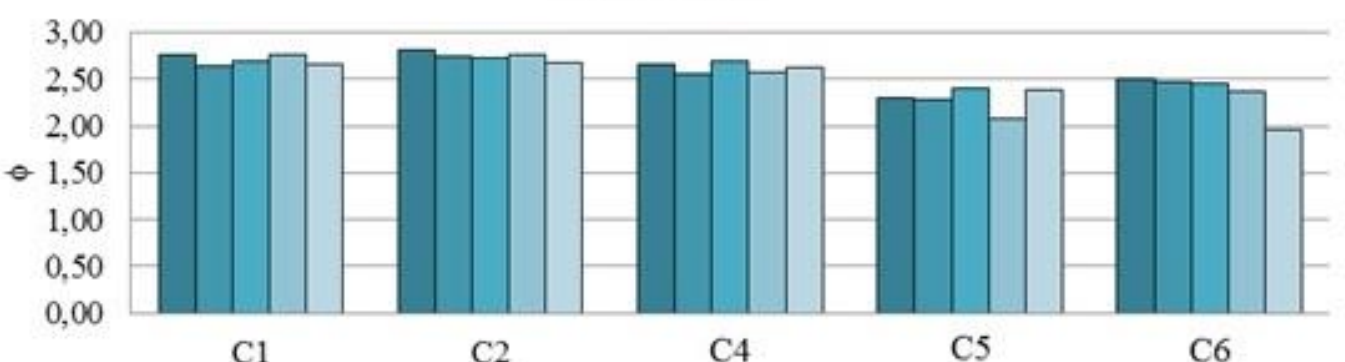

Antepraia

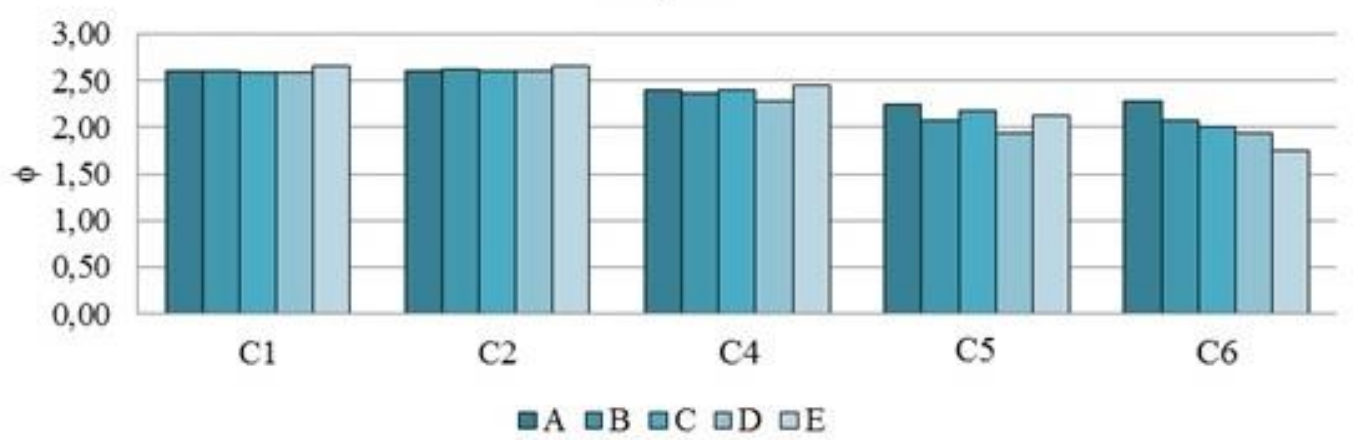

Figura 5.51: Distribuição espacial e temporal dos valores de diâmetro médio em cada compartimento praial, em phi. 
Pós-Praia

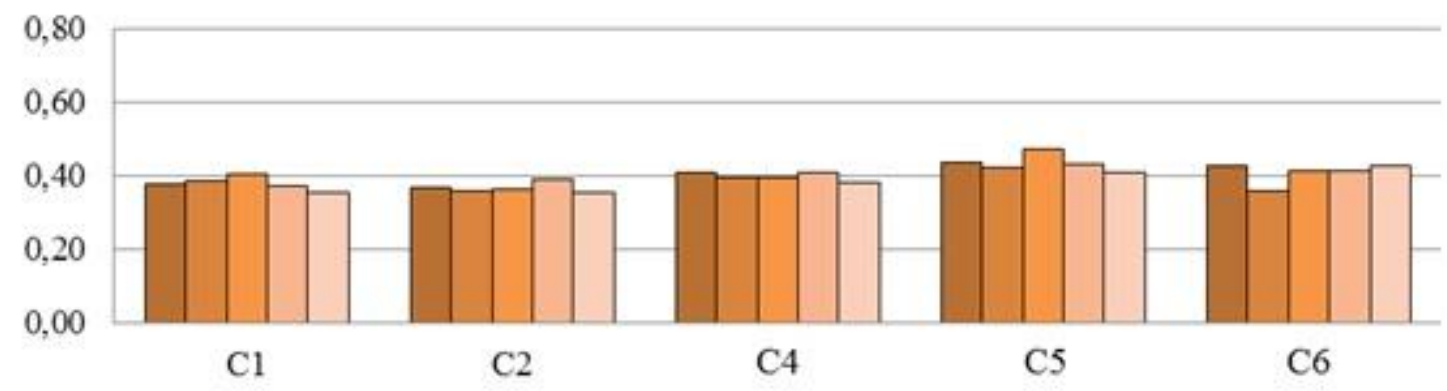

Face Praial

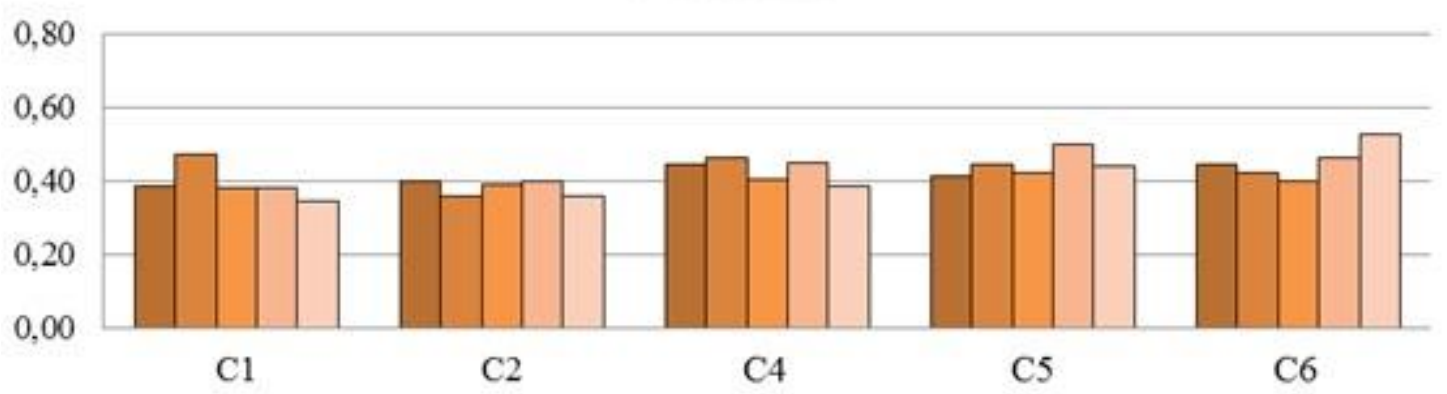

Antepraia

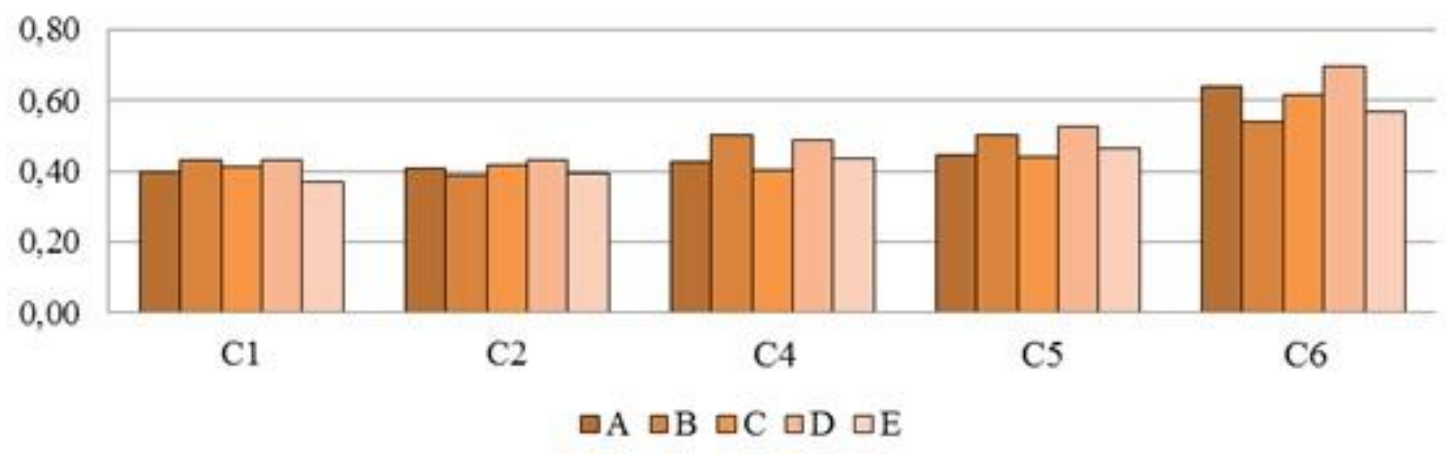

Figura 5.52: Distribuição espacial e temporal dos valores do grau de seleção em cada compartimento praial, em phi.

\subsubsection{Morfologia}

Os resultados sazonais dos levantamentos de campo mostram importantes variações ao longo do sistema praial da Ilha Comprida. Os diferentes setores avaliados responderam de forma distinta aos processos costeiros atuantes durante os levantamentos.

De modo geral, os setores mais extremos da ilha representados pelos caminhamentos C1 e C6 apresentaram tendências erosivas ao término do monitoramento, enquanto os caminhamentos C2 e C4 apresentaram tendências de acresção. O caminhamento C5 também apresentou erosão, mas com valores bem menos 
expressivos. Analisando os mapas de diferenças altimétricas elaborados entre o último e o primeiro levantamento, tais características se mostram mais evidentes.

Para $\mathrm{C} 1$, uma faixa bem marcada de perda de sedimentos pode ser reconhecida na região da escarpa. A Figura 5.53 mostra uma tendência geral de perda de sedimentos, principalmente na porção próxima da escarpa, com perdas maiores que -2,5 em alguns pontos. Fazendo um acompanhamento da isolinha de altura de dois metros, a qual se situa entre o topo e a base da escarpa, podemos reconhecer uma taxa de recuo proeminente, que alcança valores de dez metros em alguns pontos (Figura 5.54). Entretanto, também é possível reconhecer que a maioria deste recuo ocorreu entre os períodos A e B, sendo devido à ação de ondas mais energéticas, associadas a marés de sizígia e meteorológicas, que levam tais ondas a incidirem na base da escarpa, aumentando significativamente a taxa de recuo. Neste período, a força de onda alcançou valores superiores a $750000 \mathrm{~W} / \mathrm{m}$, com uma deriva residual negativa de aproximadamente -30. É importante frisar que, em relação à deriva residual, esta sempre apresentou valores negativos, representando uma retirada de sedimentos maior que a chegada em todos os períodos. Todavia, esta retirada nem sempre foi reconhecida nos valores volumétricos dos perfis praiais, como pode ser reconhecido no período $\mathrm{D}$, o qual apresentou aumento de cerca de $2000 \mathrm{~m}^{3}$, mesmo apresentando valores de deriva residual superiores a -100 (Tabela 5.7). 


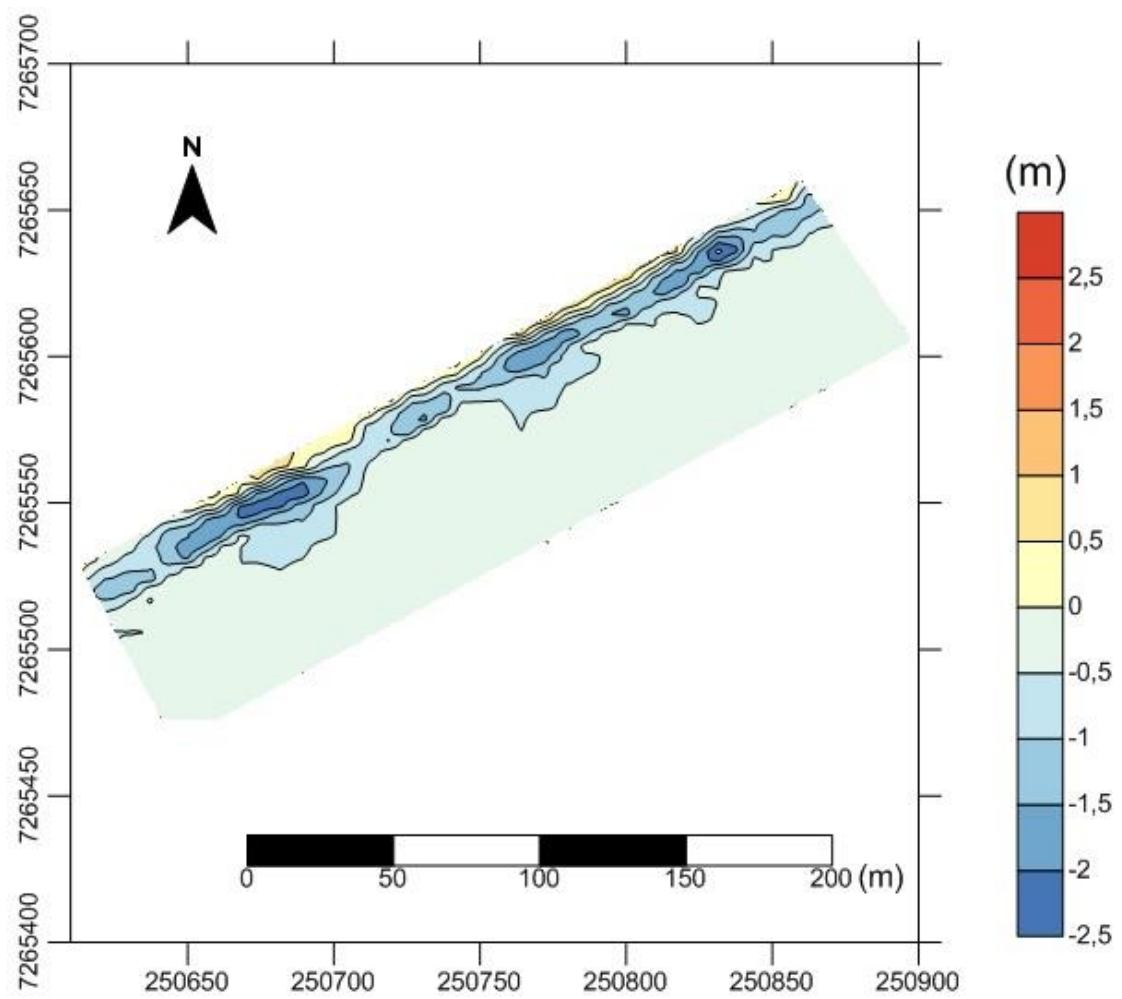

Figura 5.53: Mapa de variação altimétrica elaborado entre o último e o primeiro levantamento para o Caminhamento 1. As cores frias indicam erosão, enquanto as cores quentes, acresção.

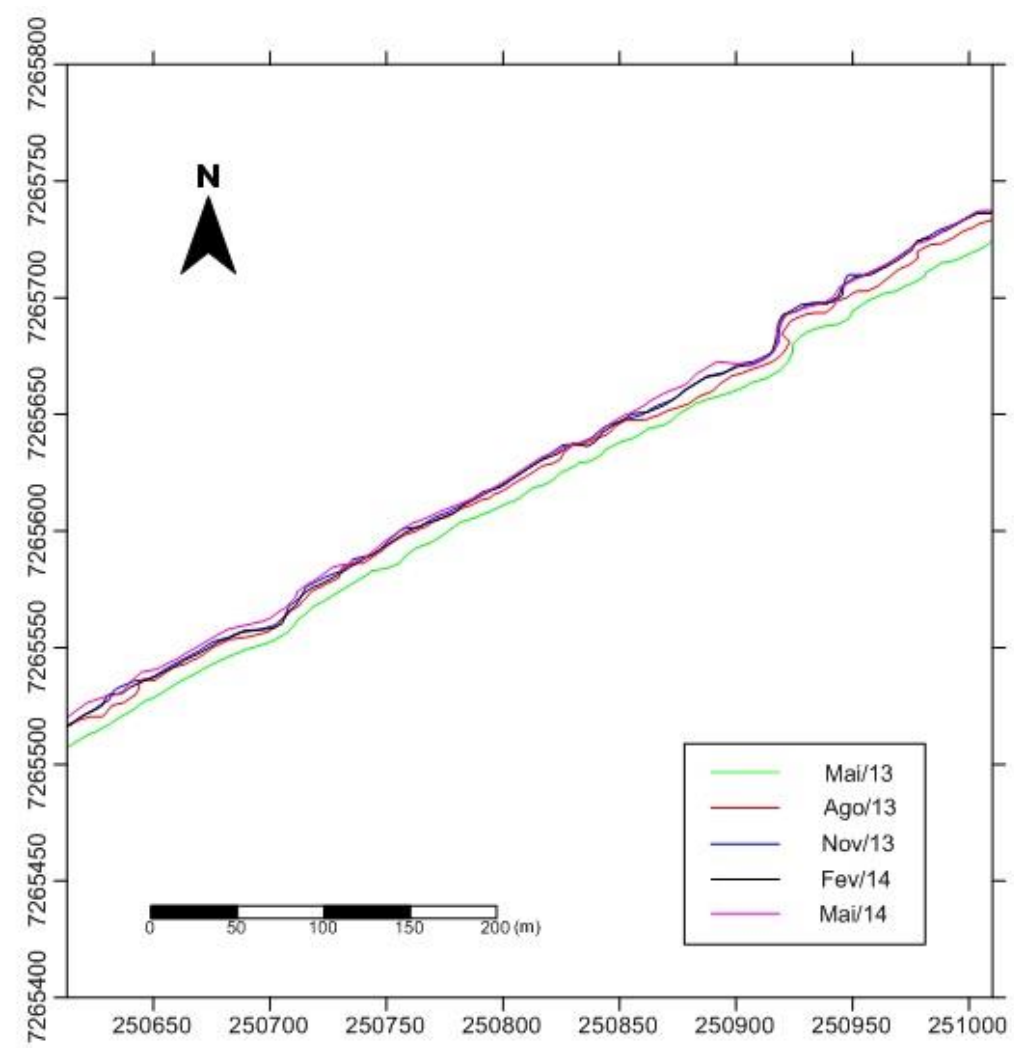

Figura 5.54: Acompanhamento da isolinha de altura de dois metros, evidenciando o recuo ocorrido no Caminhamento 1 ao longo do monitoramento. 
Tabela 5.7: Sumarização dos dados referentes ao Caminhamento 1.

\begin{tabular}{ccccccccccccccc}
\hline & \multicolumn{2}{c}{ Altura } & & \multicolumn{2}{c}{ Volume $\left(\mathbf{m}^{3}\right)$} & \multicolumn{2}{c}{$\begin{array}{c}\text { Parâmetros onda } \\
\text { locais }\end{array}$} & \multicolumn{2}{c}{$\begin{array}{c}\text { Potência } \\
(\mathbf{W} / \mathbf{m})\end{array}$} \\
\hline Periodo & $\begin{array}{c}\text { Máximo } \\
(\mathrm{m})\end{array}$ & $\begin{array}{c}\text { Mínimo } \\
(\mathrm{m})\end{array}$ & $\begin{array}{c}\text { Declividade } \\
\text { da face }\left({ }^{\circ}\right)\end{array}$ & Topo & Base & Hs & T & Dir & Total & Residual & Período \\
A & 4,38 & 0,22 & 1,8 & 47113 & 28583 & 0,52 & 6,65 & 104 & 120 & $-7,82$ & 411886 \\
B & 4,14 & 0,07 & 1,6 & 39965 & 23994 & 0,69 & 8,38 & 117 & 425 & $-29,00$ & 769439 \\
C & 4,34 & $-0,10$ & 1,6 & 37946 & 22593 & 0,49 & 5,21 & 73 & -895 & $-70,59$ & 423683 \\
D & 4,71 & $-0,03$ & 1,9 & 40942 & 25203 & 0,4 & 4,96 & 83 & -175 & $-136,50$ & 275848 \\
E & 3,94 & 0,00 & 1,8 & 37623 & 23730 & 0,48 & 5,36 & 99 & -541 & $-81,48$ & 238975 \\
\hline
\end{tabular}

O Caminhamento 2 apresentou uma tendência de acresção ao longo do período, com um aumento de cerca de $3000 \mathrm{~m}^{3}$ em relação ao primeiro levantamento (Tabela 5.8). O aumento mais significativo ocorreu no período $\mathrm{D}$, correspondente à época de verão, com atuação de ondas pouco energéticas provindas do quadrante NE. O período B e C, representantes de inverno e primavera, não resultaram em grandes variações volumétricas neste setor, apesar das ondulações de inverno serem mais energéticas em cerca de $40 \%$ em relação ao período C, e $45 \%$ mais energética em relação ao período A. A deriva residual se mostrou negativa para todo período, apesar de não apresentar visual relação com as variações volumétricas apresentadas. $\mathrm{O}$ mapa de variação de altimetria mostra uma tendência de retirada de sedimentos do pós-praia e de acresção nos compartimentos inferiores (Figura 5.55). Tal retirada do pós-praia pode estar associada ao transporte eólico, que depositaria tal sedimento em regiões laterais adjacentes ou na duna frontal; ou a eventos de onda que distribuiriam este sedimento ao longo de todo perfil inferior.

Tabela 5.8: Sumarização dos dados para o Caminhamento 2

\begin{tabular}{|c|c|c|c|c|c|c|c|c|c|c|c|}
\hline \multicolumn{4}{|c|}{ Altura } & \multicolumn{2}{|c|}{ Volume $\left(\mathbf{m}^{3}\right)$} & \multicolumn{3}{|c|}{$\begin{array}{c}\text { Parâmetros onda } \\
\text { locais }\end{array}$} & \multicolumn{2}{|c|}{ Deriva } & \multirow{2}{*}{$\begin{array}{c}\begin{array}{c}\text { Potência } \\
\text { (W/m) }\end{array} \\
\text { Período }\end{array}$} \\
\hline Periodo & $\begin{array}{l}\text { Máximo } \\
(\mathrm{m})\end{array}$ & $\begin{array}{l}\text { Mínimo } \\
\text { (m) }\end{array}$ & $\begin{array}{c}\text { Declividade } \\
\text { da face }\left(^{\circ}\right)\end{array}$ & Topo & Base & Hs & $\mathrm{T}$ & Dir & Total & Residual & \\
\hline $\mathbf{A}$ & 3,09 & 0,33 & 1,5 & 57324 & 50282 & 0,50 & 6,65 & 104 & 285 & -57 & 384280 \\
\hline B & 3,53 & 0,37 & 1,7 & 58666 & 52201 & 0,67 & 8,38 & 116 & 724 & -127 & 712700 \\
\hline C & 3,57 & 0,38 & 1,6 & 58990 & 51682 & 0,49 & 5,22 & 73 & -697 & -158 & 417202 \\
\hline D & 3,29 & 0,81 & 1 & 66245 & 60904 & 0,40 & 4,96 & 83 & -66 & -18 & 259551 \\
\hline $\mathbf{E}$ & 3,46 & 0,51 & 1,4 & 60080 & 52903 & 0,47 & 5,36 & 99 & -388 & -83 & 233912 \\
\hline
\end{tabular}




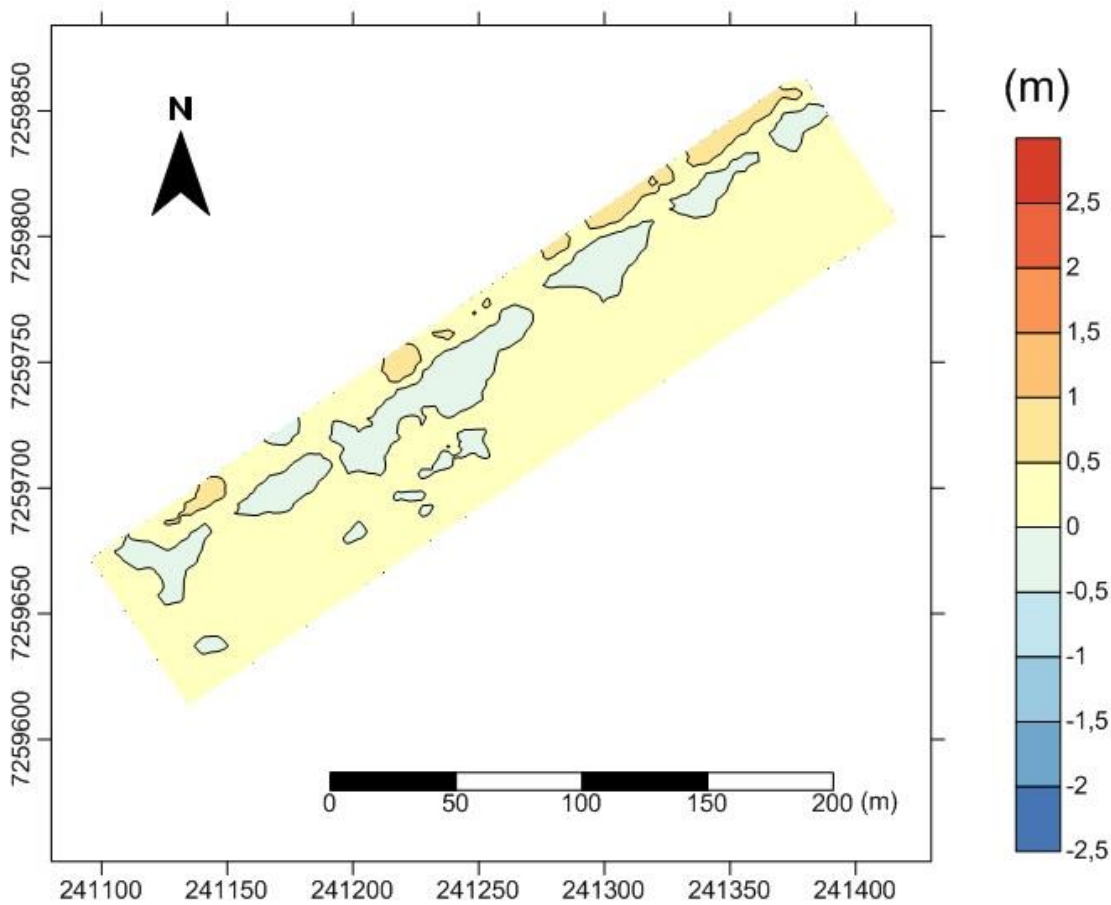

Figura 5.55: Mapa de variação altimétrica elaborado entre o último e o primeiro levantamento para o Caminhamento 2. As cores frias indicam erosão, enquanto as cores quentes, acresção.

O Caminhamento 4 apresentou uma tendência de acresção ao longo do período de análise, similar ao caminhamento 2, sendo o maior crescimento vertical dos perfis ocorrido ao longo do período D, marcado por baixa energia de onda. Comparando o primeiro levantamento com o último, temos uma tendência geral de crescimento vertical para todo o caminhamento, com algumas manchas de perda de sedimento na parte superior da face praial/pós-praia (Figura 5.56). As maiores variações volumétricas ocorreram entre os períodos C-D e D-E. Tais períodos apresentaram força de onda similar, enquanto que a deriva potencial foi maior para o último período. A deriva residual foi positiva tanto no período D quanto para $\mathrm{E}$ (Tabela 5.9).

Tabela 5.9: Sumarização dos dados para o Caminhamento 4

\begin{tabular}{ccccccccccccc}
\hline & \multicolumn{2}{c}{ Altura } & & \multicolumn{2}{c}{ Volume $\left(\mathbf{m}^{3}\right)$} & \multicolumn{3}{c}{$\begin{array}{c}\text { Parâmetros onda } \\
\text { locais }\end{array}$} & \multicolumn{2}{c}{$\begin{array}{c}\text { Deriva } \\
\text { Potência } \\
(\mathbf{W} / \mathbf{m})\end{array}$} \\
\hline Periodo & $\begin{array}{c}\text { Máximo } \\
(\mathrm{m})\end{array}$ & $\begin{array}{c}\text { Mínimo } \\
(\mathrm{m})\end{array}$ & $\begin{array}{c}\text { Declividade } \\
\text { da face }\left({ }^{\circ}\right)\end{array}$ & Topo & Base & Hs & T & Dir & Total & Residual & Período \\
A & 3,875 & $-0,244$ & 1,6 & 63270 & 54367 & 0,45 & 6,65 & 100 & 239 & -38 & 300945 \\
B & 3,465 & $-0,210$ & 1,5 & 64341 & 54418 & 0,585 & 8,38 & 112 & 586 & -79 & 542736 \\
C & 3,740 & $-0,014$ & 1,5 & 67345 & 56261 & 0,45 & 5,21 & 70 & -574 & 154 & 344708 \\
D & 4,176 & 0,165 & 1,6 & 75076 & 67288 & 0,36 & 4,96 & 79 & -70 & 105 & 208446 \\
E & 3,980 & $-0,034$ & 1,6 & 68664 & 59811 & 0,44 & 5,35 & 95 & -294 & 117 & 197925 \\
\hline
\end{tabular}




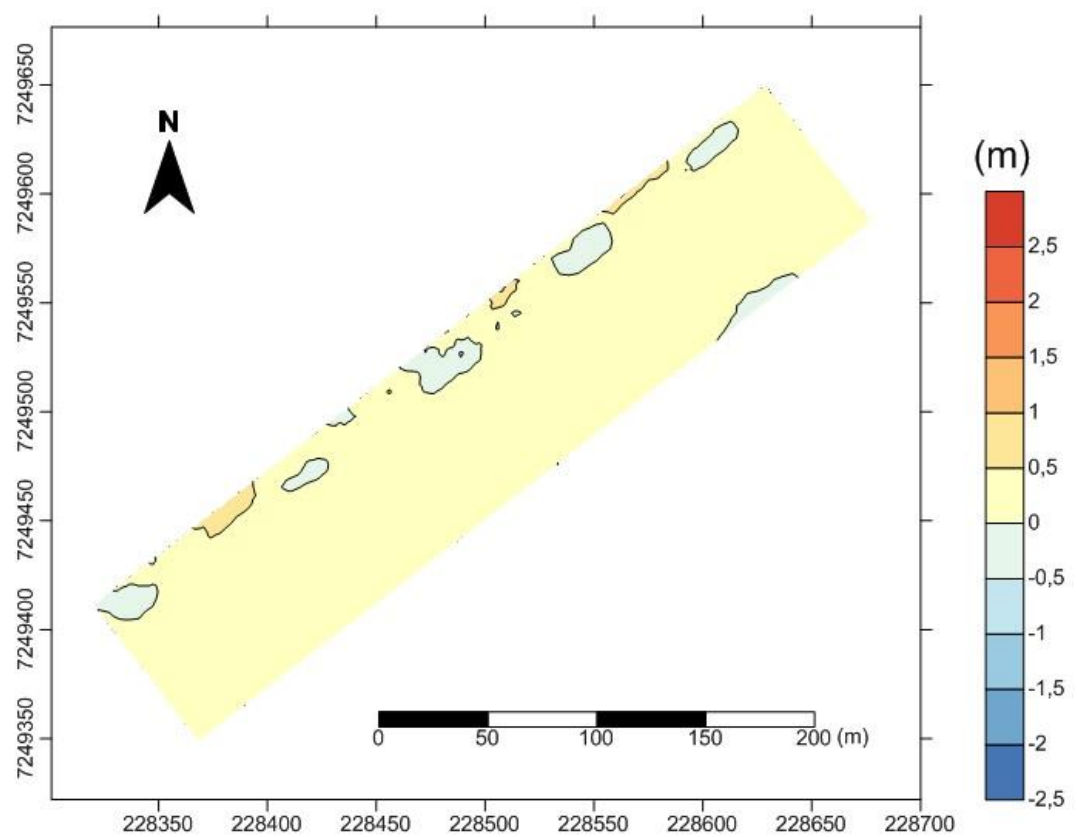

Figura 5.56: Mapa de variação altimétrica elaborada entre o último e o primeiro levantamento para o Caminhamento 4. As cores frias indicam erosão, enquanto as cores quentes, acresção.

O Caminhamento 5 apresentou tendências de erosão com valores de perda de aproximadamente $300 \mathrm{~m}^{3}$ de sedimento (Tabela 5.10). O maior período de aumento de material para o trecho se deu no período D, onde alcançou valores acima de $3000 \mathrm{~m}^{3} \mathrm{de}$ sedimento quando comparados com o primeiro. Dois períodos de perda foram reconhecidos: um entre o período $\mathrm{B}$, e outro entre o período $\mathrm{E}$. $\mathrm{O}$ período $\mathrm{B}$ foi reconhecido por uma alta força média de onda e por um residual negativo de deriva litorânea, enquanto que o período $\mathrm{E}$ foi reconhecido por uma baixa força de onda e um residual positivo. Entretanto, analisando os volumes com e sem a parte da duna frontal, percebe-se que, para este último período, a perda relativa se deu mais proeminente na região da duna frontal, como pode ser reconhecido no mapa de diferenças altimétricas (Figura 5.57).

Tabela 5.10: Sumarização dos dados para o Caminhamento 5

\begin{tabular}{|c|c|c|c|c|c|c|c|c|c|c|c|}
\hline \multicolumn{4}{|c|}{ Altura } & \multicolumn{2}{|c|}{ Volume $\left(\mathbf{m}^{3}\right)$} & \multicolumn{3}{|c|}{$\begin{array}{c}\text { Parâmetros onda } \\
\text { locais }\end{array}$} & \multicolumn{2}{|c|}{ Deriva } & \multirow{2}{*}{$\begin{array}{c}\begin{array}{c}\text { Potência } \\
\text { (W/m) }\end{array} \\
\text { Período }\end{array}$} \\
\hline Periodo & $\begin{array}{l}\text { Máximo } \\
\text { (m) }\end{array}$ & $\begin{array}{l}\text { Mínimo } \\
(\mathrm{m})\end{array}$ & $\begin{array}{c}\text { Declividade } \\
\text { da face }\left({ }^{\circ}\right)\end{array}$ & Topo & Base & Hs & $\mathrm{T}$ & Dir & Total & Residual & \\
\hline $\mathbf{A}$ & 4,01 & 0,15 & 1,3 & 49162 & 27077 & 0,42 & 6,65 & 98 & 336 & -3 & 267041 \\
\hline B & 3,40 & $-0,29$ & 1,8 & 45175 & 25395 & 0,55 & 8,38 & 111 & 791 & -36 & 477426 \\
\hline $\mathbf{C}$ & 3,76 & $-0,40$ & 1,8 & 46286 & 25267 & 0,44 & 5,21 & 69 & -465 & 225 & 322041 \\
\hline D & 3,90 & 0,00 & 1,5 & 52561 & 30621 & 0,35 & 4,96 & 77 & -27 & 165 & 189330 \\
\hline $\mathbf{E}$ & 3,88 & $-0,18$ & 1,9 & 48816 & 27919 & 0,43 & 5,35 & 93 & -214 & 185 & 183061 \\
\hline
\end{tabular}




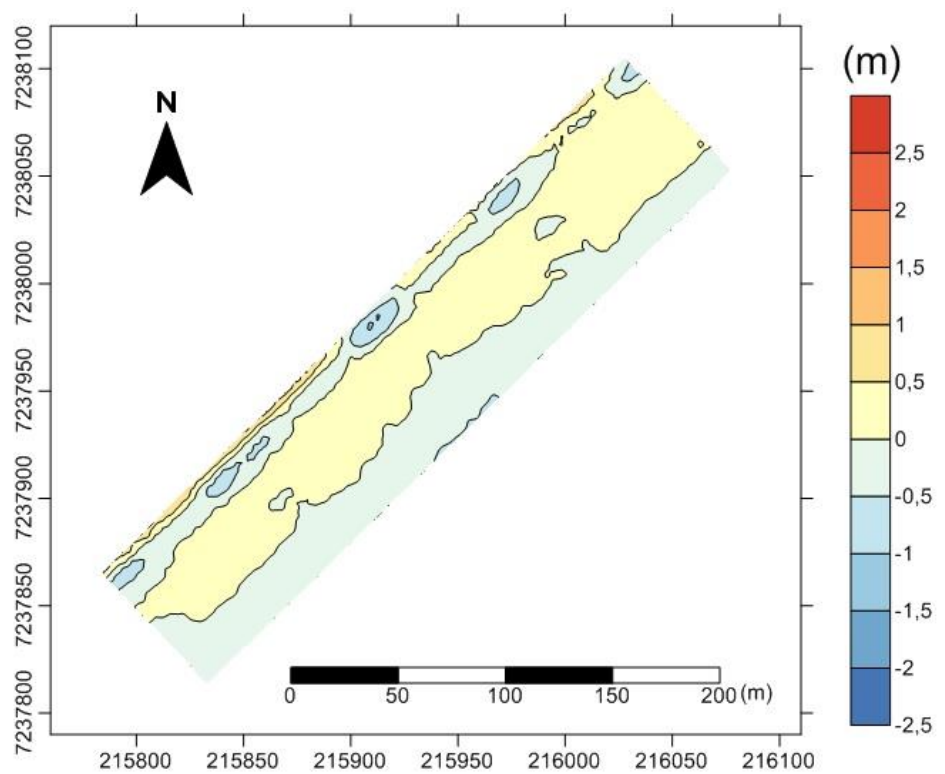

Figura 5.57: Mapa de variação altimétrica elaborado entre o último e o primeiro levantamento para o Caminhamento 5. As cores frias indicam erosão, enquanto as cores quentes, acresção.

O Caminhamento 6 apresentou uma tendência erosiva, tanto considerando a duna quanto apenas a parte dominada pelos processos praiais. Entretanto, a região da duna apresentou um crescimento em relação ao primeiro período, evidenciando um possível transporte eólico positivo. A variação volumétrica se mostrou bastante condicionada pela força de onda ao longo do período, em detrimento as mudanças de deriva tanto totais quanto residuais, com exceção ao último levantamento. Relacionando a variação volumétrica com a força média da semana anterior aos levantamentos, o ajuste é melhor reconhecido.

Tabela 5.11: Sumarização dos dados para o Caminhamento 6.

\begin{tabular}{|c|c|c|c|c|c|c|c|c|c|c|c|}
\hline \multicolumn{4}{|c|}{ Altura } & \multicolumn{2}{|c|}{ Volume $\left(\mathbf{m}^{3}\right)$} & \multicolumn{3}{|c|}{$\begin{array}{c}\text { Parâmetros onda } \\
\text { locais }\end{array}$} & \multicolumn{2}{|c|}{ Deriva } & \multirow{2}{*}{$\begin{array}{c}\begin{array}{c}\text { Potência } \\
\text { (W/m) }\end{array} \\
\text { Período }\end{array}$} \\
\hline Periodo & $\begin{array}{c}\text { Máximo } \\
(\mathrm{m})\end{array}$ & $\begin{array}{l}\text { Mínimo } \\
(\mathrm{m})\end{array}$ & $\begin{array}{c}\text { Declividade } \\
\text { da face }\left({ }^{\circ}\right)\end{array}$ & Topo & Base & $\mathrm{Hs}$ & $\mathrm{T}$ & Dir & Total & Residual & \\
\hline $\mathbf{A}$ & 3,60 & 0,53 & 1,6 & 46749 & 30454 & 0,3 & 6,66 & 84,09 & $\begin{array}{c}149,9 \\
7\end{array}$ & 742,2 & 133211,61 \\
\hline B & 3,55 & $-0,12$ & 1,7 & 40371 & 25753 & 0,37 & 8,4 & 93,81 & $\begin{array}{c}351,8 \\
1\end{array}$ & 1171,88 & 221813,08 \\
\hline C & 3,76 & $-0,42$ & 1,5 & 34956 & 20821 & 0,36 & 5,21 & 60,55 & $\begin{array}{c}- \\
117,1 \\
5\end{array}$ & 254,71 & 210316,80 \\
\hline D & 4,04 & $-0,16$ & 2,1 & 44034 & 28446 & 0,28 & 4,96 & 67,64 & $\begin{array}{c}- \\
33,69\end{array}$ & 84,12 & 107920,33 \\
\hline $\mathbf{E}$ & 3,92 & $-0,06$ & 1,7 & 42907 & 27075 & 0,34 & 5,35 & 81,5 & 42,20 & 155,95 & 44149,86 \\
\hline
\end{tabular}




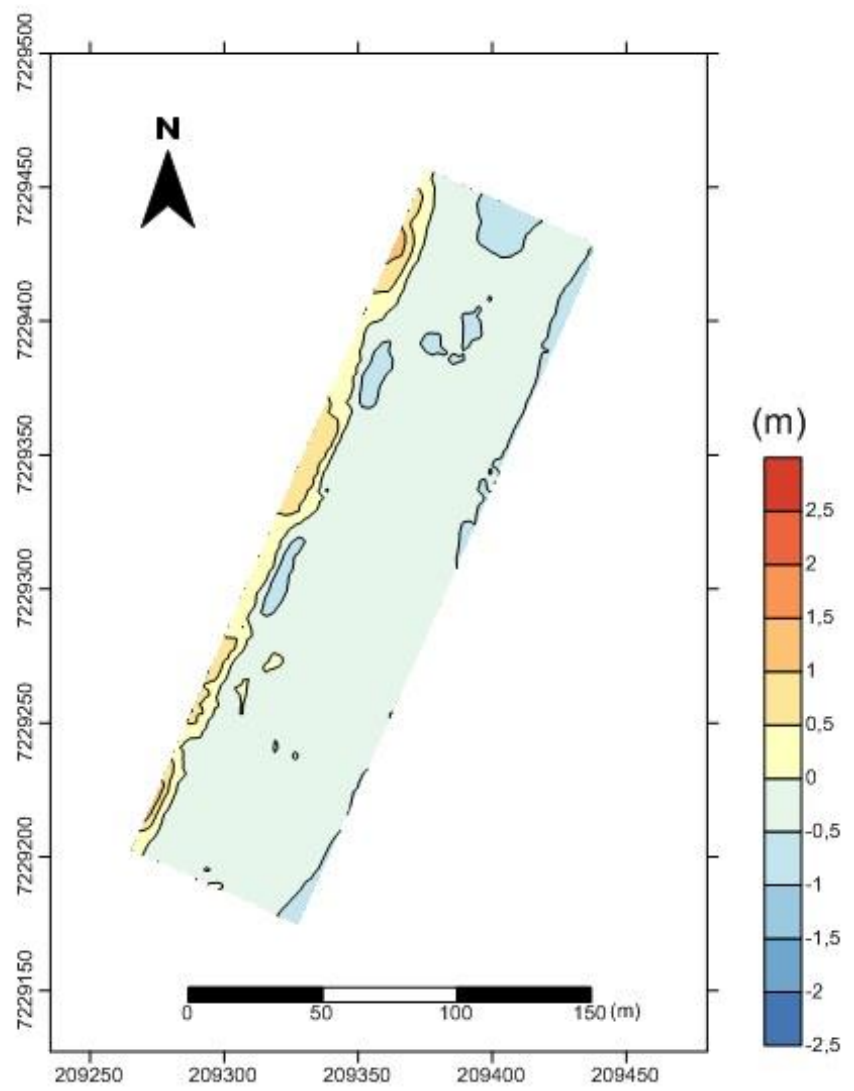

Figura 5.58: Mapa de variação altimétrica elaborado entre o último e o primeiro levantamento para o Caminhamento 6. As cores frias indicam erosão, enquanto as cores quentes, acresção.

A resposta sazonal dos caminhamentos às forçantes hidrodinâmicas também ocorreu de maneira distinta. Os perfis mostram as variações morfológicas para trecho em cada período de análise. Percebe-se o recuo bem definido da escarpa de erosão no C1 (Figura 5.59), bem como a engorda do perfil C2 (Figura 5.60) e C4 (Figura 5.61) durante o período de verão (D), apesar da baixa variabilidade destes às outras épocas. O C5 (Figura 5.62) também se mostrou com baixa variabilidade em relação às diferentes épocas do ano, enquanto que o C6 (Figura 5.63) se mostrou bem ativo, respondendo de forma proeminente as variações sazonais das forçantes hidrodinâmicas.

Os mapas de diferença altimétrica para cada trecho também evidenciam estes resultados, estando representados no Anexo II. Para $\mathrm{C} 1$, percebe-se que as maiores perdas se deram na região da escarpa entre o período $\mathrm{A}$ e $\mathrm{B}$, e um pouco entre $\mathrm{B}$ e $\mathrm{C}$. Um pequeno aumento durante as estações de baixa energia também foram reconhecidos, seguido de uma tendência de retirada de sedimento da parte da face praial no último levantamento $(\mathrm{E})$, com baixo recuo evidente na região da escarpa. Em C2 e C4, os trechos responderam de maneira similar ao tipo de onda incidente, com ganho e perdas na altura do perfil majoritariamente entre 0,5 e $-0,5$. Estes trechos ainda indicam uma 
possível importância no transporte transversal, o que pode ser evidenciado pela variação inversa entre a porção superior e inferior, na maioria dos períodos. O Caminhamento 5 também possui uma variação inversa entre a parte superior e inferior da praia, sendo mais proeminente entre os períodos B-C, C-D e D-E, enquanto que o período entre A-B mostrou uma tendência mais homogênea de retirada de sedimentos. O Caminhamento 6 mostra alta variabilidade, ocorrendo variações de altura entre 1 e -1. É importante frisar o período entre B-C, onde há uma retirada de sedimentos na parte inferior da duna, o qual causou uma pequena escarpa de erosão reconhecida em campo e também nos dados; e o período de verão, com um grande acúmulo sedimentar na região da face praial, evidenciado tanto nos perfis quanto no mapa de diferença altimétrica.

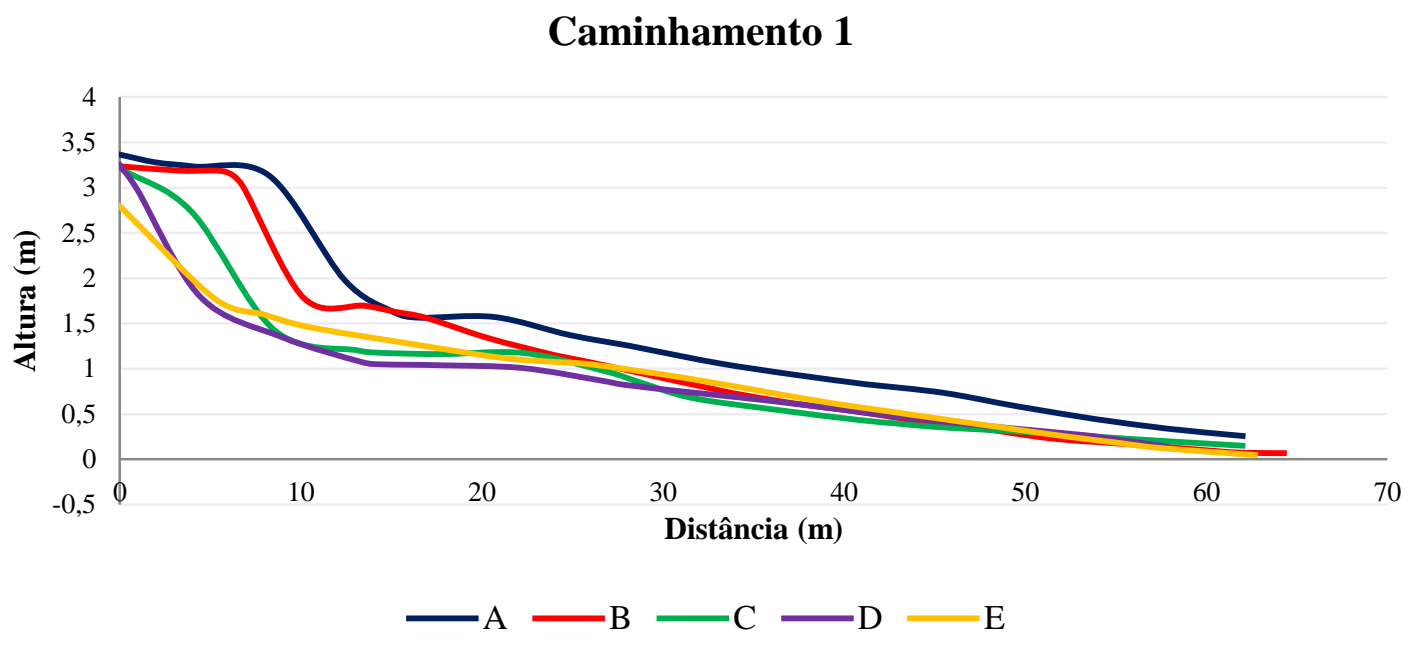

Figura 5.59: Perfis praiais e sua variabilidade em relação aos diferentes períodos para o Caminhamento 1.

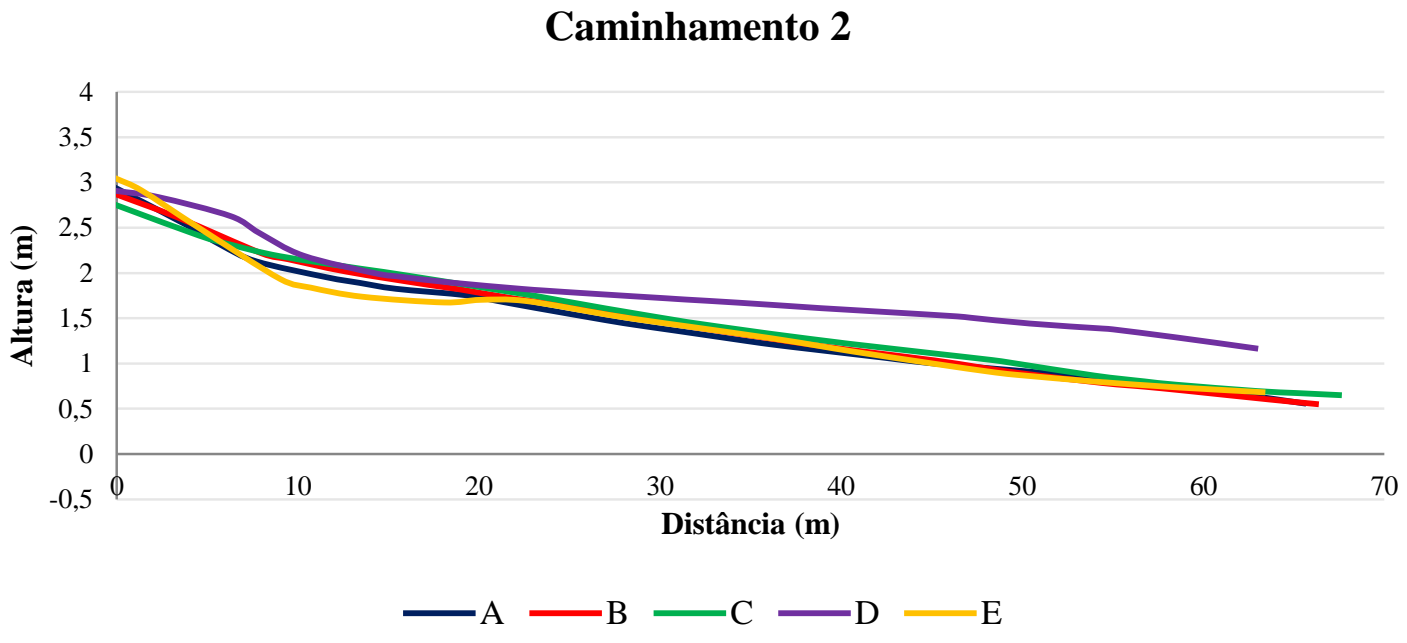

Figura 5.60: Perfis praiais e sua variabilidade em relação aos diferentes períodos para o Caminhamento 2. 


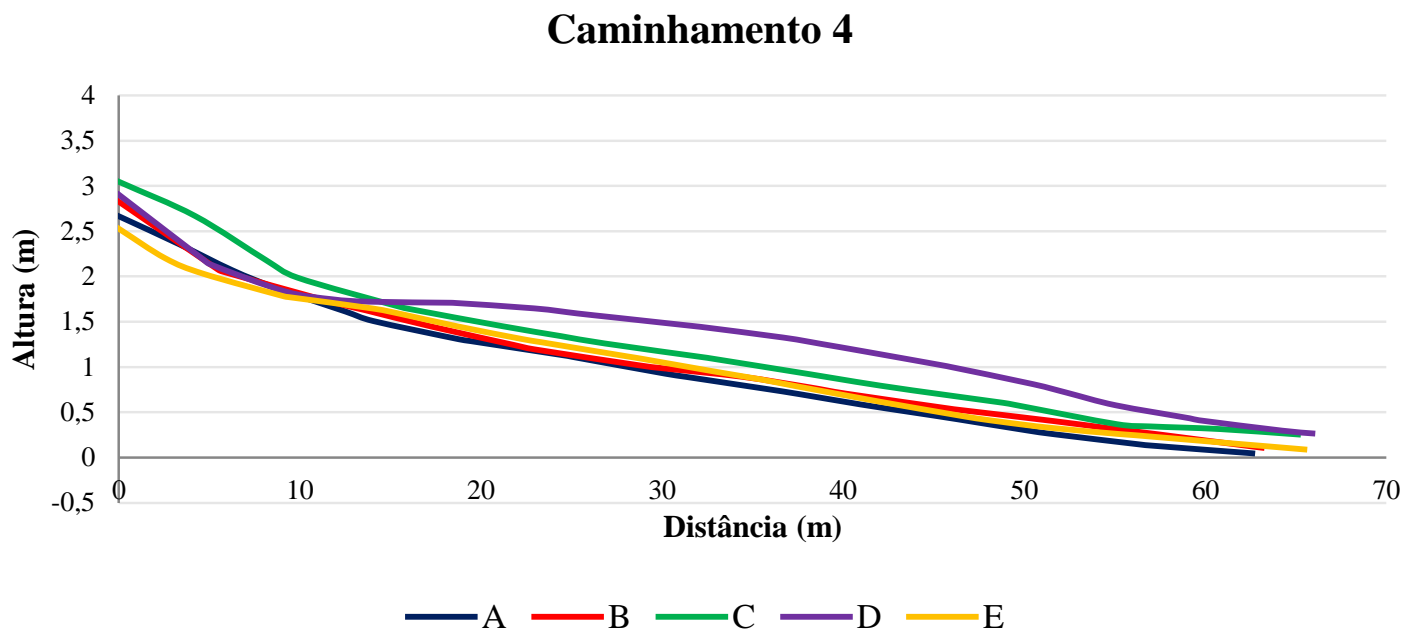

Figura 5.61: Perfis praiais e sua variabilidade em relação aos diferentes períodos para o Caminhamento 4.

\section{Caminhamento 5}

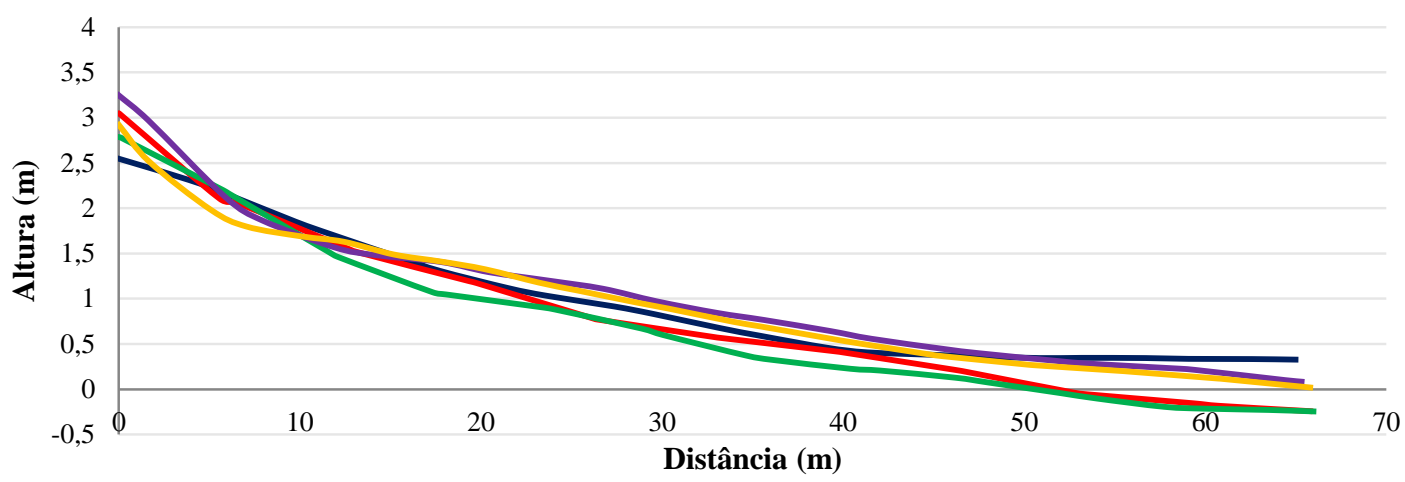

$\longrightarrow \mathrm{A}-\mathrm{B}-\mathrm{C}-\mathrm{D}=\mathrm{E}$

Figura 5.62: Perfis praiais e sua variabilidade em relação aos diferentes períodos para o Caminhamento 5.

\section{Caminhamento 6}
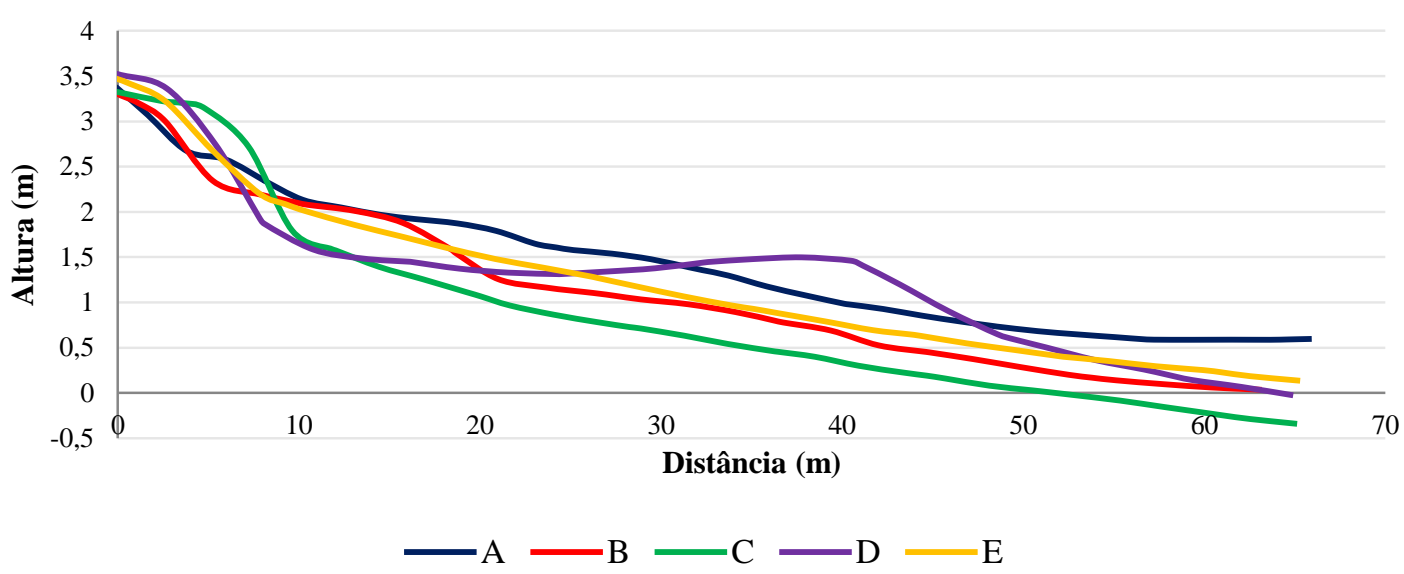

Figura 5.63: Perfis praiais e sua variabilidade em relação aos diferentes períodos para o Caminhamento 6. 
Os resultados de volume mostram uma tendência de variação espacial geral ao longo da ilha (Figura 5.64). Utilizando o valor normalizado, temos que o caminhamento mais ao norte possui os menores valores médios, sendo seguido pelo caminhamento 5 . Tais caminhamentos estão locados em regiões onde há ação erosiva permanente (C1) e ação erosiva a qual não é constante naquela área, ou pelo menos não evidente por geoindicadores ambientais (C5). Todavia, apesar do recuo da escarpa ativa de erosão ter sido reconhecido no $\mathrm{C} 1$, os volumes médios por metro são similares entre estes dois caminhamentos. Além disso, as regiões de C2 e C4 apresentaram os maiores valores dentre os cinco analisados, mostrando-se uma região que pode ser denotada como trapeadora de sedimentos entre a ilha inteira. A semelhança entre os $\mathrm{C} 2$ e $\mathrm{C} 4$ é bem definida pelos valores de volume, enquanto que a maior perda no primeiro período do caminhamento 1 também é reconhecida. É importante também frisar que a resposta volumétrica entre cada setor se deu de maneira distinta. Entre os períodos A e B, erosão foi reconhecida nos caminhamentos 1, 5 e 6 , enquanto houve acresção nos caminhamentos 2 e 4 . Entre os períodos B e C, erosão só foi reconhecida nos trechos extremos C1 e C6, sendo acresção presente nos caminhamentos 2, 4 e 5. Para os dois últimos períodos, entre C-D e D-E, a ilha respondeu de maneira homogênea entre os diferentes trechos, sendo caracterizada uma acresção no período de verão em todos os caminhamentos, seguida por uma erosão com a entrada do outono.

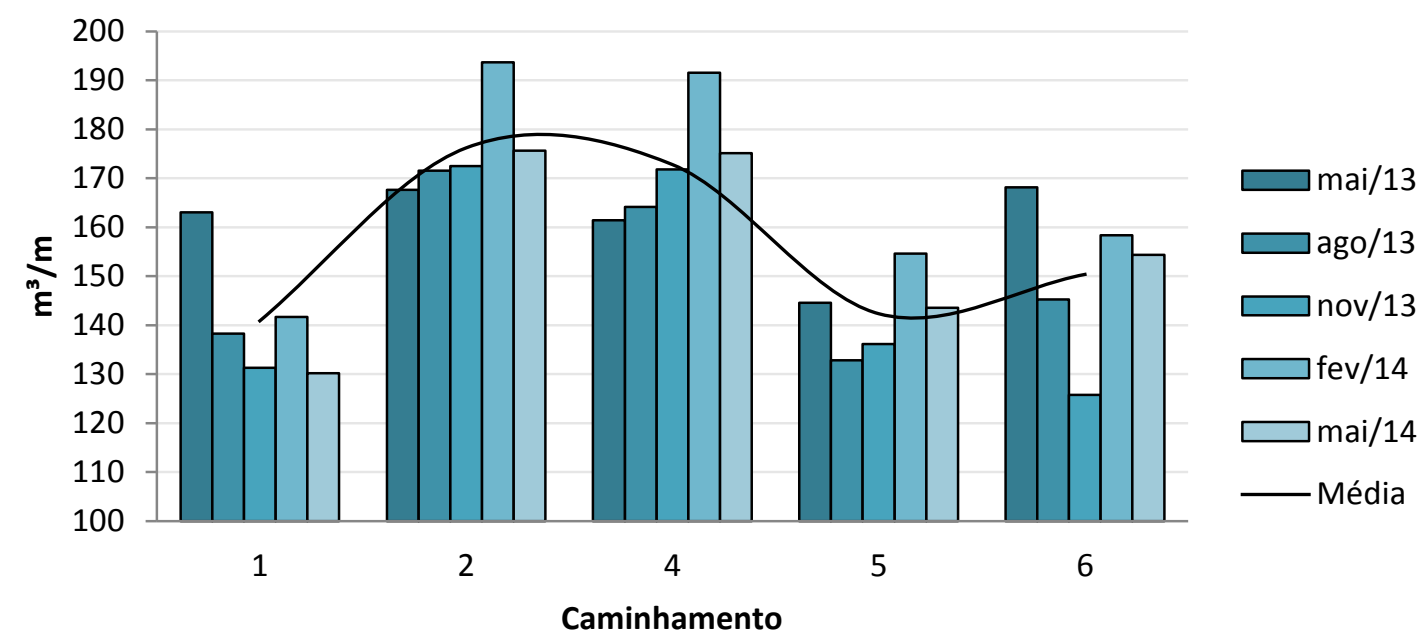

Figura 5.64: Gráfico da variação do volume normalizado para cada caminhamento, evidenciando tanto a variação temporal quanto espacial. 


\section{DISCUSSÃO}

Os resultados encontrados permitiram diversas conclusões acerca da variabilidade morfo-sedimentar do sistema praial da Ilha Comprida. Os sedimentos disponíveis em uma praia estão diretamente submetidos a uma série de processos que os transportam e consequentemente altera a morfologia do ambiente em diferentes escalas, tanto longitudinalmente, levando o sedimento a diferentes setores, quanto transversalmente, retirando-o da área emersa para a área submersa ou vice-versa (Siegle \& Asp, 2007; Van Rijn, 2011). Neste âmbito, em primeira instancia, os processos de transporte longitudinal podem ser relacionados em larga escala com áreas de potencial erosão, em locais onde há divergência residual de correntes, e com potencial progradação, onde há convergência residual de transporte (Stone et.al. 1992; Cipriani \& Stone, 2001; Bittencourt et al., 2005). Deste modo, é possível reconhecer que o balanço negativo de sedimentos ao longo do sistema-praial da Ilha Comprida tem relação direta com o as tendências de transporte longitudinal encontradas no presente trabalho.

Considerando os resultados de Sousa (2013), onda há a localização recente dos pontos de erosão, a ilha apresenta basicamente dois setores com aspectos erosivos: o setor centro-sul (trecho 5 superior e 4 inferior) e o setor norte (trechos 2 superior e 1) (Figura 6.1). Tais regiões são similares às encontradas por Souza e Suguio (1996), indicando uma provável manutenção espacial dos processos erosivos. No setor norte, região que apresenta os maiores indícios de erosão, percebe-se uma tendência de divergência de corrente de deriva litorânea, a qual varia em magnitude sazonalmente, mas não espacialmente. Já para o setor centro-sul, este também apresenta tendências de divergência residual de deriva litorânea, como apresentado por outros autores (Souza, 1997; Nascimento, 2006). Todavia, esta apresentou uma tendência migratória ao longo das estações do ano, se tornando relativamente maior e se deslocando para locais mais ao sul da Ilha Comprida durante meses mais energéticos. Este crescimento associado à migração pode ter influência na tendência final de recuo desta região, tendo em vista que esta perda de sedimentos atuará em uma área maior, resultando em menores valores absolutos por unidade de área.

Todavia, as distribuições de força de onda também tem relação espacial com as tendências erosivas, como as tendências de divergência residual de transporte longitudinal. A região norte concentra os maiores valores de força de onda tanto numa 
analise integrada dos 30 anos, quanto para a média de cada estação desta série temporal, quando comparados com os outros trechos da ilha. Considerando o setor centro-sul, este apresenta um relativo pico de força de onda, mas com tendências mais amenas se comparada com a da região norte. Deste modo, a distribuição de força de onda para a região pode ter um importante papel nos processos erosivos em larga escala assim como a tendência de divergência residual de correntes, e não apenas em uma perspectiva de escala sazonal de processos, como discutido por Short (1978). Sazonalmente, a tendência de aumento da energia em direção a NE mostra que esta distribuição se mantém também nesta escala.

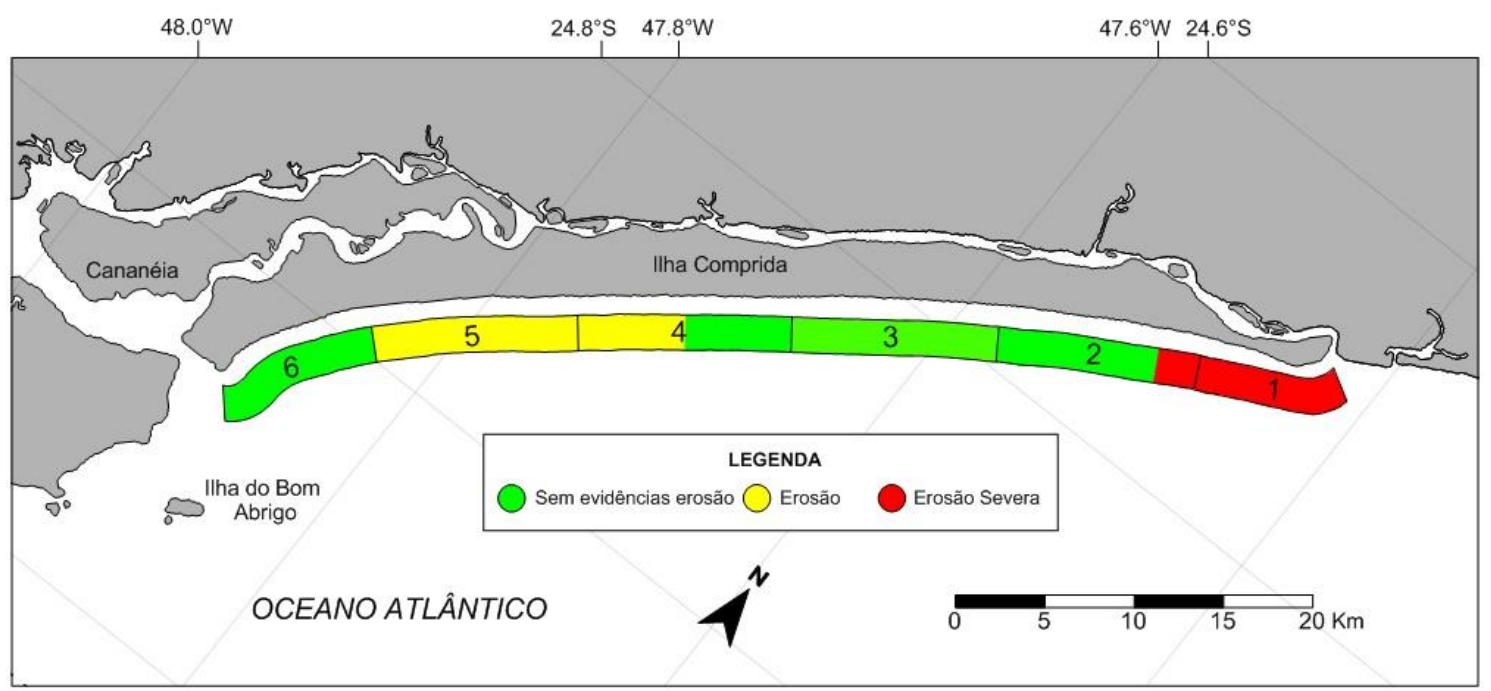

Figura 6.1: Setorização dos locais de erosão ao longo da Ilha Comprida (adaptado de Sousa (2013)).

Além dos trechos com tendência erosiva, a ilha apresenta regiões de tendências à convergência do transporte longitudinal, bem como de baixos valores de força de onda relativa. Estas regiões estão alocadas na região centro-norte (entre os trechos 4-3 e 3-2), e na região sul da ilha (trecho 6), sendo caracterizadas pela grande quantidade de sedimentos. Considerando o cenário de tendência de transporte para NE, a área de centro-norte pode ser considerada com um setor de trapeamento dos sedimentos provindo das porções sul, devido a seu baixo valor de força de onda e pela tendência de convergência residual da deriva neste setor. Assim, o material provindo de sul perde competência, diminuindo sua taxa de transporte para as regiões mais ao norte, retardando a sua chegada nestas porções.

O transporte longitudinal se mostrou fortemente condicionado pela presença da ilha do Bom Abrigo e pela orientação da linha de costa. Devido a sua orientação, a costa 
favorece transportes relativos a ondulações de E e S, as quais chegam a zona costeira com ângulos menos ortogonais e, assim, geram condições favoráveis para o transporte lateral. Entretanto, ondas de SE, as quais são energéticas e representam cerca de $18 \%$ da ocorrência, são importantes para o transporte lateral apenas no trecho 6, principalmente pelo seu baixo valor de azimute, favorecendo assim o transporte condicionado por essas ondas. Para os outros trechos, apesar de também contribuir de forma mais amena para o transporte lateral, tais ondas são mais importantes para o transporte transversal, retirando os sedimentos das zonas emersas para a zona de surf, e disponibilizando tal material para o transporte longitudinal. A variação da orientação da linha de costa ao longo da ilha, iniciando com valores próximos a $5^{\circ}$ e chegando a valores de $60^{\circ}$ na ponta norte, denotam em uma variação no ângulo de incidência de ondas ao longo da ilha inteira, gerando uma tendência de concentração da energia das ondas nos extremos da ilha devido aos processos de refração (Figura 6.2). Deste modo, as ondas tendem a formar uma espécie de leque ao aproximarem da costa, concentrando sua energia nas pontas e diminuindo sua intensidade no centro. Entretanto, a ilha do Bom Abrigo gera uma zona de sombra para a ponta sul da ilha, influenciando consequentemente neste processo e, consequentemente, na distribuição de energia ao longo da ilha. Assim, baixos valores de energia são encontrados nesta zona de sombra, sendo a tendência de aumento da energia nos extremos estancada na porção mais ao centro-sul da ilha. Deste modo, os padrões de refração ao longo da ilha e a presença da ilha do Bom Abrigo podem explicar a concentração de energia de onda nos dois trechos de erosão, onde possuem os maiores valores relativos de força de onda ao longo da Ilha Comprida. 


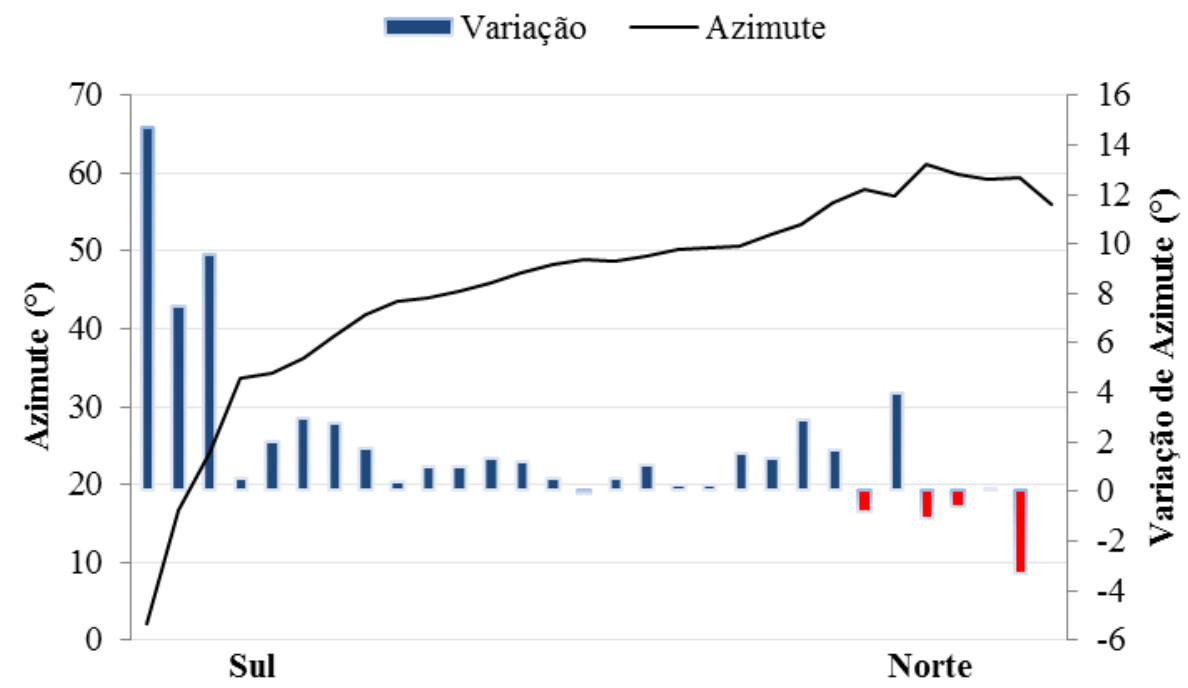

Figura 6.2: Variação do azimute ao longo da costa ca Ilha Comprida, evidenciando o aumento de azimute em direção ao norte. As barras azuis indicam acréscimo dos valores de azimute em relação ao setor ao sul adjacente. A linha preta evidencia o valor de azimute.

Apesar dos indícios apresentados por Nascimento (2006) de uma divergência direcional de deriva litorânea na parte sul da ilha através de dados sedimentológicos, esta não se mostrou presente através dos resultados presentes de tendência, sendo apenas a divergência residual encontrada, ou seja, de perda de sedimentos, sendo esta muito bem relacionada com os processos erosivos encontrados na região. Todavia, esta ausência pode estar associada tanto devido à resolução empregada no presente trabalho, a qual pode ter atenuado tais variações, quanto a possíveis variações de espaço e tempo menores, as quais podem ter ficado refletidas nas características dos sedimentos coletados pelo autor.

Os resultados dos levantamentos também mostraram estas tendências gerais relativas para a Ilha Comprida. Os caminhamentos 4 e 5 mostraram-se com maior volume médio em relação aos outros três caminhamentos, sendo o caminhamento 1 , relativo a porção norte, o que apresentou menor volume relativo por metro, seguido pelo caminhamento 5, situado em uma região próxima aos processos erosivos da região centro-sul. Entretanto, ao contrário do esperado, o volume médio entre o caminhamento 1 e 5 são similares. Os caminhamentos 1 e 5 se mostraram, respectivamente, 10 e 9\% menores em relação a média encontrada para todos os caminhamentos, enquanto que os caminhamentos 2 e 4, apresentam respectivamente 13 e $10 \%$ acima da média. Deste modo, a força de onda pode ser um agente acelerador do processo erosivo, retirando o sedimento das porções emersas com mais facilidade, mas com a necessidade de uma 
divergência de deriva litorânea para retirar esse sedimento disponibilizado. Considerando os padrões de transporte médios para estes períodos, apesar de apresentarem uma variação direcional nas resultantes de transporte, a ponta norte apresentou um processo de divergência residual similar ao encontrado nas tendências gerais de transporte com os 30 anos de análise, assim como setores de divergência e convergência foram encontrados ao longo das regiões mais centrais da Ilha. A força de onda também mostrou esse padrão de tendência, com maiores valores relativos nas porções norte. Todavia, neste período o pico de energia para todos os levantamentos no setor centro-sul foi menor se comparado com as tendências gerais, sendo constatada uma tendência um pouco mais linear de crescimento da energia de onda para NE. Além disso, as distribuições espaciais de força de onda se mostraram com um gradiente menor de variação para forças relativamente baixas, (semana, anterior ao levantamento D), mostrando que quanto mais energéticas forem as ondas, mais evidente será esta flutuação de valores relativos será evidenciada, principalmente na ponta norte.

A distribuição sedimentar encontrada ao longo dos caminhamentos, principalmente na antepraia, mostra a tendência geral de transporte para NE, já evidenciada por métodos sedimentares por outros autores (Souza, 1997; Nascimento, 2006). O aumento da seleção do grão e a diminuição do tamanho do mesmo indicam direção de transporte, sendo tal padrão evidenciado nas amostras de sedimento. Ainda, os valores de direção de onda para água rasa nos setores dos caminhamentos exemplificam a tendência explanada de abertura dos arcos de onda na região central devido aos processos de refração, sendo ondas dos setores mais ao norte, como caminhamento 1 , incidindo com valores de direção maiores que para as regiões mais ao sul, apesar de ambas estarem condicionadas a uma mesma forçante externa de ondas de água profunda.

A variabilidade sazonal dos processos hidrodinâmicos interfere diretamente no transporte local de sedimentos. De acordo com Tessler \& Goya (2005), a costa sudeste brasileira recebe no maior período do ano ondulações provindas de NE devido aos ventos alísios, com uma mudança para os quadrantes S-SE devido a atuações de sistemas frontais, os quais possuem uma variabilidade ao longo do ano. 
Tabela 6.1: Sumarização dos dados de onda e variação volumétrica para os diferentes campos e caminhamentos.

\begin{tabular}{|c|c|c|c|c|c|c|c|c|c|c|c|}
\hline & $H s$ & $T p$ & Dir & $H s$ & $T p$ & Dir & \multicolumn{5}{|c|}{ Variação de volume (\%) } \\
\hline Campo & Período & Período & Período & Semana & Semana & Semana & 1 & 2 & 4 & 5 & 6 \\
\hline A & 1,9 & 9,4 & 148 & 2,3 & 9,1 & 161 & & & & & \\
\hline B & 2,2 & 10,7 & 166 & 2,2 & 9,4 & 138 & -25 & 4 & 3 & -12 & -23 \\
\hline $\mathbf{C}$ & 2,5 & 9,1 & 127 & 3,2 & 10,8 & 186 & -7 & 1 & 8 & 3 & -19 \\
\hline D & 2 & 8,3 & 119 & 1,8 & 6,5 & 66 & 10 & 21 & 20 & 18 & 33 \\
\hline $\mathbf{E}$ & 1,9 & 7,8 & 124 & 2,1 & 8,1 & 131 & -11 & -18 & -16 & -11 & -4 \\
\hline
\end{tabular}

Considerando os resultados de Marquez (2007) para a região, ondas de leste com alturas até 1 metros atuaram na erosão, enquanto ondas de $\mathrm{E}$ com alturas maiores que 1 metro atuaram na deposição. Para o quadrante $S$, o padrão de inverte, com ondas com alturas até 1 metro atuando na deposição, enquanto que ondas maiores que 1 metro atuam na erosão. Tais resultados encontrados pela autora são relativos a área do caminhamento 6, e refletem o padrão encontrado tanto analisando as médias para o período inteiro, quanto para a semana anterior. Considerando o padrão encontrado de ondas sempre maiores que 1 metro de quadrantes entre SE-S, estes atuaram na erosão da praia no caminhamento 6, com exceção do período $\mathrm{D}$, que apresentou uma acresção de cerca de $30 \%$ relativo ao período anterior. Considerando a semana anterior, este padrão encontrado pela autora se mostra mais evidente, visto que no único período em que houve a acresção, ondas do quadrante NE incidiam sobre a praia, com alturas maiores que 1 metro. Entretanto, este padrão não é repetido para todos os outros caminhamentos (Tabela 6.1).

É possível perceber que os períodos D e E atuaram de maneira similar em termos de erosão e deposição para todos os caminhamentos, enquanto que os períodos B e $\mathrm{C}$ atuaram erodindo as regiões mais próximas aos extremos, com deposição nas regiões centrais da ilha. Analisando os dados médios das características das ondas para cada período, não fica claro uma relação entre os parâmetros de onda e as variações sedimentares. Além das características das ondas em si, a deriva litorânea e sua característica de divergência e convergência residual podem ter influência direta na variabilidade volumétrica da área, em ambas as escalas.

A baixa relação entre as características das ondas e os caminhamentos pode estar relacionada ao fato de que a metodologia abordada não consegue adquirir dados das porções inferiores da praia, não sendo possível contabilizar as variações de sedimento nesta região, bem como a troca de sedimentos entre a zona de surfe e as regiões mais 
profundas a isobata de fechamento do perfil praial. O único local onde foi possível identificar uma tendência foi justamente o caminhamento 6, já estudado por Marquez (op.cit.), e o caminhamento 1, localizado nos extremos da ilha. Devido a maior energia de onda nas porções mais ao norte, as respostas nas porções superiores refletem de maneira mais proeminente. Para o caminhamento 1, o baixo grau de força de onda também aparentemente favorece este reflexo na porção, visto que menores variações nesta capacidade geram variações notáveis nas porções superiores.

A partir do padrão de erosão e deposição encontrado para cada trecho, e levando em consideração os padrões de clima de ondas em larga escala encontrados, temos que as ondas com características erosivas serão mais atuantes do que as ondas com característica de deposição, tanto em larga escala (aproximadamente 60\% das ondulações), quanto sazonalmente (inverno $-65 \%$, verão $-55 \%$ ).

O baixo n-amostral para cada trecho impossibilitou uma profunda análise estatística, no âmbito de reconhecer qual dos processos teve maior influência no período analisado. Apesar das tentativas de normalizações para tentativa do cálculo considerando a ilha como um todo, este método não se mostrou eficaz para tal abordagem. A hipótese de que para a região, um período de atuação de onda menor, referente a uma semana em comparação a três meses, pode ter maior reflexo no padrão volumétrico encontrado para a área, vai de encontro com os resultados de Quartel et. al.(2008), onde as variações de uma praia condicionada por um regime de micromaré foi mais condicionada com as ondulações referentes a um período anterior a 8 dias do levantamento, em detrimento de períodos muito maiores. Todavia, para a presente área de estudo, tal hipótese deve ser mais bem avaliada e testada a partir de índices estatísticos, de modo a averiguar qual o tempo de atuação prévia das ondas se correlaciona melhor com os processos de erosão e acresção, para os diferentes trechos. Além disso, integração com diferentes estimativas, como deriva residual e a força de onda, bem como o diâmetro médio dos sedimentos, devem ser levados em consideração, tendo em vista que todos estes geram influência significativa para a capacidade de transporte e variação volumétrica em um perfil praial. Ainda, a influência das desembocaduras nos processos de transporte praiais, bem como na introdução de novos sedimentos ao sistema, não foi averiguado, podendo ser importante para as variabilidades encontradas nas duas extremidades da ilha.

Reconhecendo tais padrões para a ilha, estudos referentes a variações interanuais devido a eventos do tipo ENSO, os quais influem na dinâmica atmosférica do Atlântico 
Sul e, consequentemente, dos padrões de onda incidentes, devem ser analisados, de modo a reconhecer a influencia de tais variáveis climáticas nos processos costeiros condicionantes da Ilha Comprida. Ainda, estudos referentes aos padrões em escalas não abordadas por este trabalho, nos diferentes trechos, devem ser profundamente averiguadas para a real compreensão das variações setorizadas da dinâmica sedimentar praial da Ilha Comprida.

Em suma, nas escalas trabalhadas, os processos erosivos estiveram associados a tendências de divergências residuais da deriva litorânea, sendo o setor onde há erosão ao norte mais influenciado que no centro-sul devido a manutenção espacial da divergência ao longo das estações e por possuir os maiores valores de força de onda. Devido à tendência a convergência e baixa força de onda no setor centro-norte, sedimentos provindos dos setores mais ao sul não alcançam as zonas mais ao norte, fator corroborado pelos levantamentos de campo. A erosão presente na região centro-sul pode ser considerada mais amena devido a maior área de atuação da divergência residual da região, a qual não apresenta manutenção espacial. Os setores localizados nas extremidades da ilha são menos estáveis que os setores centrais, enquanto que os sedimentos, apesar de não apresentarem variabilidade temporal, apresentam variações espaciais condizentes com os padrões hidrodinâmicos encontrados. 


\section{CONCLUSÕES}

O presente estudo analisou o clima de ondas, bem como a distribuição da força de onda e dos padrões de deriva litorânea ao longo do sistema praial de Ilha Comprida numa perspectiva interanual e sazonal, fornecendo importantes subsídios para a compreensão dos processos de erosão, morfodinâmica e transporte de sedimentos para a região.

- O clima de onda predominante de S, ENE e SSW representa 60\% das ondulações na costa sudeste paulista, formando ondas de 1,5 metros e 8 segundos. Sazonalmente, há uma rotação nos quadrantes predominantes, com o predomínio de $\mathrm{S}$ e SW nos meses de outono e inverno, e ENE nos meses de verão e primavera.

- A força de onda se mostrou maior no mês de setembro, com valores também elevados nos meses de maio, junho e julho, e menores valores relativos nos meses de verão.

- A deriva predominante para a ilha foi para NE, com variações de intensidade ao longo dos trechos, sendo mais efetiva na porção sul do que na porção norte.

-Padrões de divergência e convergência residuais são observados e se refletem no padrão sedimentar encontrado nas praias de Ilha Comprida. Os padrões de divergência associados aos trechos com erosão costeira e os de convergência com as praias com grande acúmulo sedimentar.

- Sazonalmente, a divergência residual da porção centro-sul sofre uma migração e um relativo aumento da sua área de atuação para locais menos setentrionais com a entrada de meses com características de onda mais energéticas, enquanto a divergência do setor norte se mantém espacialmente.

- A força de onda mostrou uma distribuição na costa onde a porção norte possui os maiores valores, enquanto que há um relativo pico na porção centro-sul da ilha, se comparado com os valores médios encontrados. As áreas com valores relativamente baixos estão associadas às áreas que não apresentam indícios erosivos, enquanto que os locais com maiores força de onda estão associadas as regiões onde há geoindicadores de erosão ativa. Sazonalmente, em larga escala, os picos dos valores se mantém espacialmente, estando esta distribuição associada aos padrões de refração e a presença da ilha do Bom Abrigo. 
- As associações de autores pretéritos acerca dos tipos de ondulações incidentes com as variações volumétricas encontradas mostraram-se coerentes para as regiões mais próximas aos extremos da ilha, enquanto que não foram relacionadas com as regiões mais centrais da ilha.

- A distribuição volumétrica normalizada mostra que os setores 2 e 3 possuem maior quantidade de sedimento, enquanto que os setores 1 e 4 mostram-se com os menores valores para a ilha, corroborando com o resultado encontrado relativo ao padrão de transporte e distribuição de sedimentos praiais baseado na deriva litorânea e força de onda.

- Os sedimentos mostraram baixa variabilidade sazonal tanto local quanto espacial referente ao diâmetro médio e ao grau de seleção. Espacialmente, entretanto, os sedimentos mostraram uma tendência constante de diminuição do tamanho do grão e aumento do seu selecionamento em direção à ponta NE da ilha, evidenciando o transporte sedimentar longitudinal para NE.

\section{Sugestões para trabalhos futuros}

A avaliação integrada do sistema praial, tendo em vista aspectos meteorológicos, oceanográficos e geológicos são de extrema importância para a real compreensão dos processos de dinâmica atual da região, bem como para estudos sobre a evolução da área. Sugere-se para próximos estudos na área:

- Quantificação dos processos com maior significância estatística referentes as variações morfo-sedimentares da área

- Análises para reconhecimento das variações referentes aos processos climáticos globais, bem como previsões para os futuros cenários de aquecimento global.

- Definição da influência quantitativa das desembocaduras para o sistema praial da ilha como um todo seja no aporte sedimentar quanto nas possíveis variações hidrodinâmicas condicionadas pelas mesmas.

- Análise das variações de escala diária dos setores, de modo a averiguar as diferentes escalar de erosão e deposição nos diferentes compartimentos.

- Estudos acerca da dinâmica eólica praial atual na Ilha Comprida. 


\section{Referências bibliográficas}

ALLAN, J.C. \& KOMAR P.D. 2006. Climate Controls on U.S. West coast erosion processes. Journal of Coastal Research, n. 22(3), p. 511-529.

ALMEIDA, F. F. M. 1976. The system of continental rifts bordering the Santos Basin, Brazil. Anais da Academia Brasileira de Ciências, v.48 (supl.).p. 15-26.

ALMEIDA, F.F.M. \& CARNEIRO C.D.R. 1998. Origem e evolução da Serra do Mar. Revista Brasileira de Geociências, n. 28, p. 135-150.

ANTHONY, E. J. 1998. Sediment-wave parametric characterization of beaches. Journal of Coastal Research, n.14(1), 347-352.

ARAÚJO, C. E. S.; FRANCO, D.; MELO, E. \& PIMENTA, F. 2003. Wave regime characteristics of the southern Brazilian Coast. International Conference on Coastal and Port Engineering in Developing Countries, COPEDEC VI, Colombo, Sri Lanka, Proceedings. Paper 97. CD-ROM.

BARCELOS, J. H. 1975. Sedimentação e subambientes deposicionais da Ilha Comprida, São Paulo. Dissertação de mestrado. Universidade de São Paulo, Instituto de Geociências, 155p.

BECEGATO, J. L. \& SUGUIO, K. 2007. Impacto Ambiental antrópico na APA (Área de Proteção Ambiental) Da Ilha Comprida (SP): da pré-história à atualidade. Revista UNG - Geociências V.6, N.1, p.107-117.

BIRD, E.C.F., 2008. Coastal Geomorphology: An introduction. Wiley and Sons, Chichester. $411 \mathrm{p}$.

BITTENCOURT, A. C. S. P.; DOMINGUEZ, J. M. L.; MARTIN, L. \& SILVA, I. R. 2005. Longshore transport on the northeastern Brazilian coast and implications to the location of large scale accumulative and erosive zones: an overview. Mar. Geol., 219:219-234.

BITTENCOURT, A. C. S. P.; DOMINGUEZ, J. M. L.; MARTIN, L. \& SILVA, I. R. 2000. Patterns of sediment dispersion coastwise of the State of Bahia - Brazil. An. Acad. Bras. Cienc. v. 72, n. 2, p. 271-287. 
BITTENCOURT, A. C. S. P.; DOMINGUEZ, J. M. L.; MARTIN, L. \& SILVA, I. R. 2003. Uma aproximação de primeira ordem entre o clima de ondas e a localização, de longa duração, de regiões de acumulação flúvio-marinha e de erosão na costa norte do Brasil. Revista Brasileira de Geociências. v. 33, n. 2, p. 159-166.

BITTENCOURT, A. C. S. P.; MARTIN, L.; DOMINGUEZ, J. M. L.; SILVA, I. R.; \& SOUSA, D. L. 2002. A significant longshore transport divergence zone at the northeastern brazilian coast: implications on coastal quaternary evolution. An. Acad. Bras. Cienc. 74:505-518

BONETTI FILHO, J., MIRANDA, L. B. 1997. Estimativa da descarga de água doce no sistema estuarino-lagunar de Cananéia-Iguape. Brazilian Journal of Oceanography. São Paulo, v. 45, n. 1-2

CAI, F., SU, X., LIU, J., LI, B., \& LEI, G. 2009. Coastal erosion in China under the condition of global climate change and measures for its prevention. Progress in Natural Science, 19(4), 415-426. doi: 0.1016/j.pnsc.2008.05.034.

CALLIARI, L. J.; MUEHE, D.; HOEFEL, F. G.; TOLDO JR., E. 2003. Morfodinâmica praial: uma breve revisão. Revista Brasileira de Oceanografia. v.51, p.63-78.

CANDELLA, R. N. 1997. Estudo de casos de ondas no Atlântico Sul através de modelagem numérica. Dissertação de mestrado. Departamento de Engenharia Oceânica. Universidade federal do Rio de Janeiro - RJ. 93p.

CASSIANO, G. F.; SIEGLE, E. 2010. Migração lateral da desembocadura do Rio Itapocú, SC, Brasil: evolução morfológica e condicionantes físicas. Revista Brasileira de Ciências Brasileira de Geofísica, v. 28, n. 4, p. 537-549.

CAZZOLI, S.V. 1997. Dinâmica sedimentary atual das praias de Cibratel e ItanhaémSuarão, Município de Itanhaém, Estado de São Paulo. Dissertação de Mestrado. Instituto Oceanográfico. Universidade de São Paulo.

CIPRIANI, L. E. \& STONE, G.W. 2001. Net longshore sediment transport and textural changes in beach sediments along the Southwest Alabama and Mississippi Barrier Islands, U. S. A. Journal of Coastal Research, 17(2), 443-458. 
DAVIS JR., R. A. \& FITZGERALD, D. M. 2004. Beaches and Coasts. Blackwell Publishing. Cap 6. p. 102-114.

DILLENBURG, S.R.; ESTEVES, L.S.; TOMAZELLI, L.J. 2004. A critical evaluation of coastal erosion in Rio Grande do Sul, Southern Brazil. Anais da Academia Brasileira de Ciências ,

DOLAN, R.; HAYDEN, B.; HEYWOOD, J.; VINCENT, L. 1977. Shoreline forms and shoreline dynamics. Science, 197: 49-51;

EUROSION, 2004. Living with coastal erosion in Europe: Sediment and Space for Sustainability. URL: http://www.eurosion.org/reports-online/reports.html. Acesso em: 25 de Agosto de 2014.

FARINACEO, A. 2008. Impactos na dinâmica costeira decorrentes de intervenções em praias arenosas e canais estuarinos de áreas densamente ocupadas no litoral de São Paulo, uma aplicação do conhecimento a áreas não ocupadas. Tese de Doutorado. Instituto Oceanográfico, Universidade de São Paulo. 217 p.

FOLK, R. L. \& WARD, W. C. 1957. Brazos river bar: a study in the significance of grain size parameters. J. Sedim. Petrol. 27: 3-26.

FONZAR, B.C. 1994. A circulação atmosférica na América do Sul: os grandes sistemas planetários e subsistemas regionais que atingem o continente: Localização e trajetórias. Caderno de Geociências, n. 11, pp. 11-33.

GAGLIARDI, M. 2013. Análise de riscos costeiros a eventos atmosféricos extremos no litoral sul do Estado de São Paulo - estudo de caso na região da desembocadura de Cananéia. Dissertação de Mestrado. Instituto Oceanográfico. Universidade de São Paulo.

GAN, M. A. \& RAO, V. B. 1991. Surface cyclogenesis over South America. Mon. Weather Review.,119, 1293-1302.

GEOBRÁS - GEOBRÁS SIA - Engenharia e Fundações. 1966. Complexo VaIo Grande- Mar Pequeno- Rio Ribeira de 19uape.Relatório para o serviço do Vale do Ribeira. São Paulo, DAEE. 2 v. 
GOYA, S. C. 2011. Taxa de sedimentação atual na plataforma continental centro-norte do Embaiamento de São Paulo. Tese de Doutorado. Instituto Oceanográfico. Universidade de São Paulo.

GUEDES, C. C. F. 2009. Evolução Sedimentar Quaternária da Ilha Comprida, Estado de São Paulo. Dissertação de Mestrado. Instituto de Geociências, Universidade São Paulo.

GUEDES, C. C. F., GIANNINI, P. C. F., SAWAKUCHI, A. O., DEWITT, R., NASCIMENTO JR, D. R., AGUIAR, V. A. P., \& ROSSI, M. G. 2011. Determination of controls on Holocene barrier progradation through application of OSL dating: The Ilha Comprida Barrier example, Southeastern Brazil. Marine Geology, v. 285, n. 1, p. 1-16.

GUILLAUMON, J.R., PFEIFER, R.M., MATTOS, I.F.A., ANDRADE,W.J., SILVA, C.E.F. 1990. Macrozoneamento das terras da região do rio Ribeira de Iguape, SP. Bol. Científico, 19. Instituto Agronômico de Campinas. 181p.

HARARI, J. \& CAMARGO, R. 1994. Simulação da propagação das nove principais componentes de maré na plataforma sudeste Brasileira através de modelo numérico hidrodinâmico. Boletim do Instituto Oceanográfico 42 (1-2), 35-54

HOEFEL, F. G. 1998. Morfodinâmica de praias arenosas oceânicas - uma revisão bibliográfica. $1^{\text {a }}$.ed. Itajaí: Editora da Univali. 92 p.

HOLTHUIJSEN, L. H.; BOOJI, N.; HERBERS, T. H. C. 1989. A prediction model for stationary, short-crested waves in shallow water with ambient currents. Coastal Engineering 13: 23-54.

HOLTHUIJSEN, L.H. 2007. Waves in Oceanic and Coastal Waters, Cambridge University Press, Cambridge. 387p.

HOSKINS, B. J. \& HODGES, K.I.A. 2005. A new perspective on southern hemisphere storm tracks. Journal of climate, v.18(20): 4108-4129

IBGE. 2010. Censo Demográfico do município de Ilha Comprida-SP. URL: http://ibge.gov.br/cidadesat/xtras/perfil.php?codmun=352042. Acesso em: 08 de Junho de 2014. 
JACKSON, D. W. T., COOPER, J. A. G., RIO, L. 2005. Geological control of beach morphodynamic state. Marine Geology, v.216, p. 297-314;

KING, C. A. M. 1972. Beaches and coasts, $2^{\text {nd }}$ ed. London, Edward Arnold, 570.

KOMAR, P.D. 1998. Beach processes and sedimentation, 2nd ed. Prentice Hall.

KOTTEK, M., GRIESER, J.; BECK, C.; RUDOLF, B.; RUBEL, F. 2006. World map of the Koppen-Geiger climate classification updated. Meteorologische Zeitschrift, v. 15, n. 3, p. 259-264. DOI: 10.1127/0941-2948/2006/0130.

LEPSCH, I.F., SARAIVA, I.R., DONZELI, P.L., MARINHO, M.A., SAKAI, E.,

LIM, E.P. \& SIMMONDS, I. 2007. Southern hemisphere winter extratropical cyclone characteristics and vertical organization observed with the ERA-40 data in 1979 - 2001. Journal of Climate. v. 20, pp. 2675 - 2690.

LOGUET - HIGGINS, M. S. 1970. Longshore currents generated by obliquely incident sea waves. Journal of Geophysics Research, 75 (33): 6778-6789.

MARQUEZ, M. R. K. \& MAHIQUES, M. M. 2010. Variações morfológicas no prisma praial da Ilha Comprida (Sudeste do Brasil) - Subsídios para uma Gestão Costeira Sustentável. Revista da Gestão Costeira Integrada. 10(3): 361-379.

MARQUEZ, M. R. K. 2007. Morfodinâmica de um segmento de praia da Ilha Comprida, litoral sul do estado de São Paulo. Dissertação de Mestrado. Universidade de São Paulo, Instituto Oceanográfico. 123p.

MARTIN L, FLEXOR J-M, BLITZKOW D AND SUGUIO K. 1985. Geoid change indication along the Brazilian coast during the last 7,000 years. In: Coral Reef Congress 5, Tahiti, Proceedings, IGCP, Project 200, 3, p. 85-90.

MARTIN, L.; BITTENCOURT, A. C. S. P.; VILAS-BOAS, G. S. $1982 . \quad$ Primeira ocorrência de corais pleistocênicos da costa brasileira: datação do máximo da penúltima transgressão. Ciênc. Terra, v.1, p. 16-17,

MARTINS, C.M. 2000. Variações Morfológicas e Sedimentares de Curto Período em Perfis Praiais, Praia de Bertioga/SP. Dissertação de Mestrado, 161 f. Instituto Oceanográfico, Universidade de São Paulo. 
MARTINS, C.M. 2006. Morfodinâmica de Praia Refletiva: Estudo de Caso na Praia da Sununga, Litoral Norte do Estado de São Paulo. Tese de Doutorado, 209 f. Instituto Oceanográfico, Universidade de São Paulo.

MASSELINK, G. \& PULEO, J.A. 2006. Sediment transport and morphological change in swash zone. Continental Shelf Research, v.26, p 661-680.

MASSELINK, G. \& SHORT, A.D. 1993. The effect of tide range on beach morphodynamics and morphology: a conceptual beach model. Journal of Coastal Research, v.9(3), pp. 785-800.

MELO, M.S. 1990. A formação Pariquera-Acu e Depósitos Relacionados: Sedimentação, Tectônica e Geomorfogênese. 1990. Dissertação de Mestrado. 211 f. Instituto de Geociências, Universidade de São Paulo, São Paulo.

MENDES, D; SOUZA, E. P.; MARENGO, J.A.; MENDES, M. C. D. 2009. Climatology of extratropical cyclones over the South American - southern oceans sector. Theoretical and Applied Climatology. v. 100, p. 239-250.

MENDONÇA, F.; DANNI-OLIVEIRA, I. M. 2007. Climatologia: noções básicas e climas do Brasil. São Paulo: Oficina de Textos.

MESQUITA, A. R.; HARARI, J. 1983. Tides and tide gauges of Cananéia and Ubatuba - Brazil (Lat. 24º). São Paulo: Instituto Oceanográfico, Universidade de São Paulo, 1983. p. 1-14. (Relatório, 11).

MONICO, J. F. G. 2008. Posicionamento pelo GNSS: descrição, fundamentos e aplicações. $2^{a}$ edição. São Paulo: Editora UNESP.

MONTEIRO, C. A. F. 1969. A frente polar atlântica e as chuvas de inverno na fachada sul-oriental do Brasil: contribuição metodológica à análise rítmica de tempo no Brasil. Série teses e monografias 1. São Paulo: Instituto de Geografia, Universidade de São Paulo.

MORAIS, J.O., PINHEIRO, L.S., CAVALCANTE, A.A., PAULA, D.P., SILVA, R. L. 2008. Erosão Costeira em Praias Adjacentes às Desembocaduras Fluviais: O caso do Pontal de Maceió, Ceará, Brasil. Revista de Gestão Costeira Integrada 8(2): $61-76$ 
MUEHE, D. 1998. Estado morfodinamico praial no instante de observação: uma alternativa identificação. São Paulo. Revista Brasileira de Oceanografia, 46 (2): 157-169.

MUEHE, D. H. (ORG.). 2006. Erosão e Progradação do Litoral Brasileiro. Brasília, Ministério do Meio Ambiente, 476p.

NASCIMENTO JR, D. R. 2006. Morfologia e sedimentologia ao longo do sistema praia - duna frontal da Ilha Comprida, SP. Dissertação de Mestrado. Instituto de Geociências . 155p.

NIMER, E. 1989. Climatologia do Brasil. Rio de Janeiro. IBGE. 421p. $2^{a}$ edição.

NOBRE, C.A.; CAVALCANTI, M.A.G.; NOBRE, P.; KAYANO, M.T.; RAO, V.B.; BONATTI. J. P.; SATYAMURTI, P.; UVO, C.B.; COHEN, J.C. 1986; Aspectos da climatologia dinâmica do Brasil. Climanálise. Num. Esp., 124 p.

NORDSTROM, K. F. 2010. Recuperação de praias e dunas. São Paulo. Ed. Oficina de Textos. 263p.

NUBER, E. 2008. Evolução morfológica e sedimentológica do Arco Praial de Massaguaçú, Litoral norte de São Paulo. Dissertação de Mestrado. Universidade de São Paulo. Instituto Oceanográfico.

OLIVEIRA, U.R. 2004. Comportamento morfodinâmico e granulometria do arco praial Pântano do Sul - Açores, Ilha de Santa Catarina, SC, Brasil. Dissertação de Mestrado. Universidade Federal de Santa Catarina. Florianópolis.

PEZZA, A.B.; AMBRIZZI, T. 2003. Variability of Southern Hemisphere cyclones and anticyclones: recente trends and links with decadal variability in the Pacific Ocean. International Journal of Climatology. 16: 1075-1083.

PIANCA, C; MAZZINI, P. L. F.; SIEGLE, E. 2010. Brazilian offshore wave climate based on NWW3 reanalysis. Brasilian Journal of Oceanography, vol.58, n.1, pp. 53-70.

PONÇANO, W.L.; TESSLER, M.G.; FREITAS, C.G.L. de \& MAHIQUES, M.M. 1999. Tendências regionais de transporte se sedimentos arenosos ao longo das praias paulistanas. Geociências. v.IV (6). pp. 102-115. 
QUARTEL, S.;KROON, A.; RUESSINK, B.G. 2008. Seasonal accretion and erosion patterns of a microtidal sandy beach. Marine Geology. 250: 19-33.

RANASINGHE, R.; SYMONDS, G.; BLACK, K.; HOLMAN, R. 2004. Morphodynamics of intermediate beaches: a video imaging and numerical modelling study. Coastal Engineering. 51: 629-655.

REBOITA, M. S. 2008. Ciclones Extratropicais sobre o Atlântico Sul: Simulação Climática e Experimentos de Sensibilidade. Tese de Doutorado, 359 f. Instituto de Astronomia, Geofísica e Ciências Atmosféricas, Universidade de São Paulo.

RIBEIRO, J. S.; SOUSA, P. H. G. O.; VIEIRA, D. R.; SIEGLE, E. 2013. Evolução da vulnerabilidade à erosão costeira na Praia de Massaguaçú (SP), Brasil. Revista da Gestão Costeira Integrada. v. 13, n. 3, p.253-265

RODRIGUES, M. 2009. Modelagem numérica do comportamento de derrames de óleo como método de gestão ambiental, em planos de contingência, aplicada ao Canal de São Sebastião (SP). Tese de Doutorado. Universidade de São Paulo, Escola Politécnica. 130p.

SANT'ANNA NETO, J. L. 2005. Decálogo da climatologia do sudeste brasileiro. Revista Brasileira de Climatologia, Rio de Janeiro, v.1., p.43-60.

SANTOS, S.L.C. 2005. Um modelo de banco de dados geográficos para a resposta ao derramamento de óleo baseado na vulnerabilidade e sensibilidade do litoral paulista. Tese de Doutorado. Instituto Oceanográfico, Universidade de São Paulo. 216p.

SATYAMURTI, P.; NOBRE, C.; DIAS, P. L. S.1998. South America. In: KAROLY, D. J. \& VICENT, D.J.(EDS.). Meteorology of the Southern Hemisphere. Boston. American Meteorological Society. P.119-139

SHORT, A. D. 1978. Wave power and beach stages: A global model. In: International Conference On Coastal Engineering, 16. Hamburg, Proceedings. Hamburg, ASCE. pp. 1045-1062. 1979a. 
SIEGLE, E. \& ASP, N. E. 2007. Wave refraction and longshore transport patterns along the southern Santa Catarina coast. Brazilian Journal of Oceanography, 55(2): 109-120.

SIMMONDS, I.; KEAY, K. 2000. Variability of Southern Hemisphere Extratropical Cyclone Behavior, 1958-1997. Journal of Climate. 13:550-561.

SINCLAIR, M .R. 1994. An objective cyclone climatology fir the Southern Hemisphere. Monthly Weather Review. 122:2239-2256

SOLMAN, S.A.; MENÉNDEZ, C.G. 2001. ENSO-related variability of the Southern Hemisphere winter strom tracks over the Eastern Pacific-Atlantic sector. Journal of Atmospheric Science. 59:2128-2140

SOUSA, P. H. G. O. 2013. Vulnerabilidade à erosão costeira no litoral de São Paulo: interação entre processos costeiros e atividades antrópicas. Tese de Doutorado. Instituto Oceanográfico da Universidade de São Paulo.

SOUSA, P. H. G. O.; SIEGLE, E.; TESSLER, M.G. 2012. Vulnerability assessment of Massaguaçú Beach (SE Brazil). Ocean and Coastal Management. 77:24-30.

SOUZA, C. R de G. 1997. As células de deriva litorânea e a erosão nas praias do Estado de São Paulo. Tese de Doutorado. Universidade de São Paulo, Instituto de Geociências, 2v.

SOUZA, C. R. G., SUGUIO, K., 2003. The Coastal Erosion Risk Zoning and the São Paulo State Plan for Coastal Management. Journal of Coastal Research, SI 35 (Proceedings of the Brazilian Symposium on Sandy Beaches: Morphodynamics, Ecology, Uses, Hazards and Managemen), 530- 547. Itajaí, SC - Brazil, ISSN 0749-0208.

SOUZA, C.R.G. \& SUGUIO, K. 1996. Coastal erosion and beach morphodynamics along the State of São Paulo (SE Brazil). Anais da Academia Brasileira de Ciências, v. 68, pp. 405-424.

SOUZA, M.A.L. 2008. Benefícios Ambientais no Controle de Erosão Costeira com o uso do Dissipador de Energia "Bagwall" no litoral de Alagoas. Revista da Gestão Costeira Integrada. 8(2):139-148 
STONE, G.W.;STAPOR JR.,F.W.;MAY, J.P.;MORGAN, J.P. 1992. Multiple Sediment sources and a cellular, non-integrated, longshore drift system: Northwest Florida and Southwest Alabama coast, USA. Marine Geology. 105:101-154.

SUGUIO K, TESSLER M G. 1992. Depósitos quaternários da planície costeira de Cananéia-Iguape (SP). Publicação Especial do Instituto Oceanográfico, Universidade de São Paulo, São Paulo, v. 9, p. 1-33.

SUGUIO, K \& MARTIN, L. 1978. Formações quaternárias do litoral paulista e sul fluminense. In: International Symposium on Coastal Evolution in the Quaternary. Special publication. Sociedade Brasileira de Geologia. Instituto de Geociências. Universidade de São Paulo. 55p

SUGUIO, K; MARTIN, L.1994 Geologia do Quaternário. In: FALCONI, F.F.; NIGRO JR.,A. (eds.) Solos do litoral de São Paulo. Santos. ABMS/ASSECOB, 69-97.

TESSLER, M. G. \& MAHIQUES, M. M. 2000. Por uma terminologia sobre os sistemas praiais. In: Simpósio Brasileiro Sobre Praias Arenosas. Itajaí, 2000. Anais. Itajaí, UNIVALI, p.68-69.

TESSLER, M. G. 1988. Dinâmica sedimentar quaternária no litoral sul paulista. Tese de doutorado. Universidade de São Paulo, Instituto Oceanográfico. 276p.

TESSLER, M.G.; GOYA, S.C., 2005. Conditioning factors of coastal processes in the Brazilian Coastal Area. Revista do Departamento de Geografia, n. 17, p. 11-23.

TOLMAN, H. L. 1999. User manual and system documentation of WAVEWATCH III version 1.18. Tech. note 166 .

TORGE, W. 2001. Geodesy. Walter de Gruyter, 416 p.

UNCED, 1992. Protection of oceans, all kinds of seas, including enclosed and semienclosed seas, and coastal areas and the protection, rational use and development of their living resources. In: NORDSTROM, K. F. 2010. Recuperação de praias e dunas. São Paulo. Ed. Oficina de Textos. 263p.

VAN RIJN, L. C. 2011. Coastal Erosion and control. Ocean \& Coastal Management. 54: 867-887. 
WRIGHT, L. D.; CHAPPELL, J.; THORN, B.G.; BRADSHAW, M. P. \& COWELL, P. 1979. Morphodynamics of refletive and dissipative beach and inshore systems: Southeastern Australia. Marine Geology, v.32(1-2), pp.105-140.

WRIGHT, L. D.; SHORT, A. D. 1984. Morphodynamic variability of surf zones and beaches: a synthesis. Marine Geology, v.56(1/4), pp. 93-118.

WRIGHT, L.D.; GUZA, R.T.; SHORT, A.D. 1982. Dynamics of a high energy dissipative surf zone. Marine Geology, v.45, pp. 41-62.

WRIGHT, L.D.; SHORT, A.D.; BOON III, J.D.; HAYDEN, B. KIMBALL, S.; LIST, J.H. 1987. The morphodynamic effects of incident wave groupiness and tide range on an energetic beach. Marine Geology. 74: 1-20.

ZALAN, P.V.; OLIVEIRA, J.A.B. 2005. Origem e evolução estrutural do Sistema de Riftes Cenozóicos do Sudeste do Brasil. Boletim de Geociências da Petrobrás. N. 13, pp. 269-300. 
ANEXO I - TABELAS GRANULOMÉTRICAS 
Tabela 8.1: Dados granulométricos referentes ao período A. As posições espaciais são aproximadas.

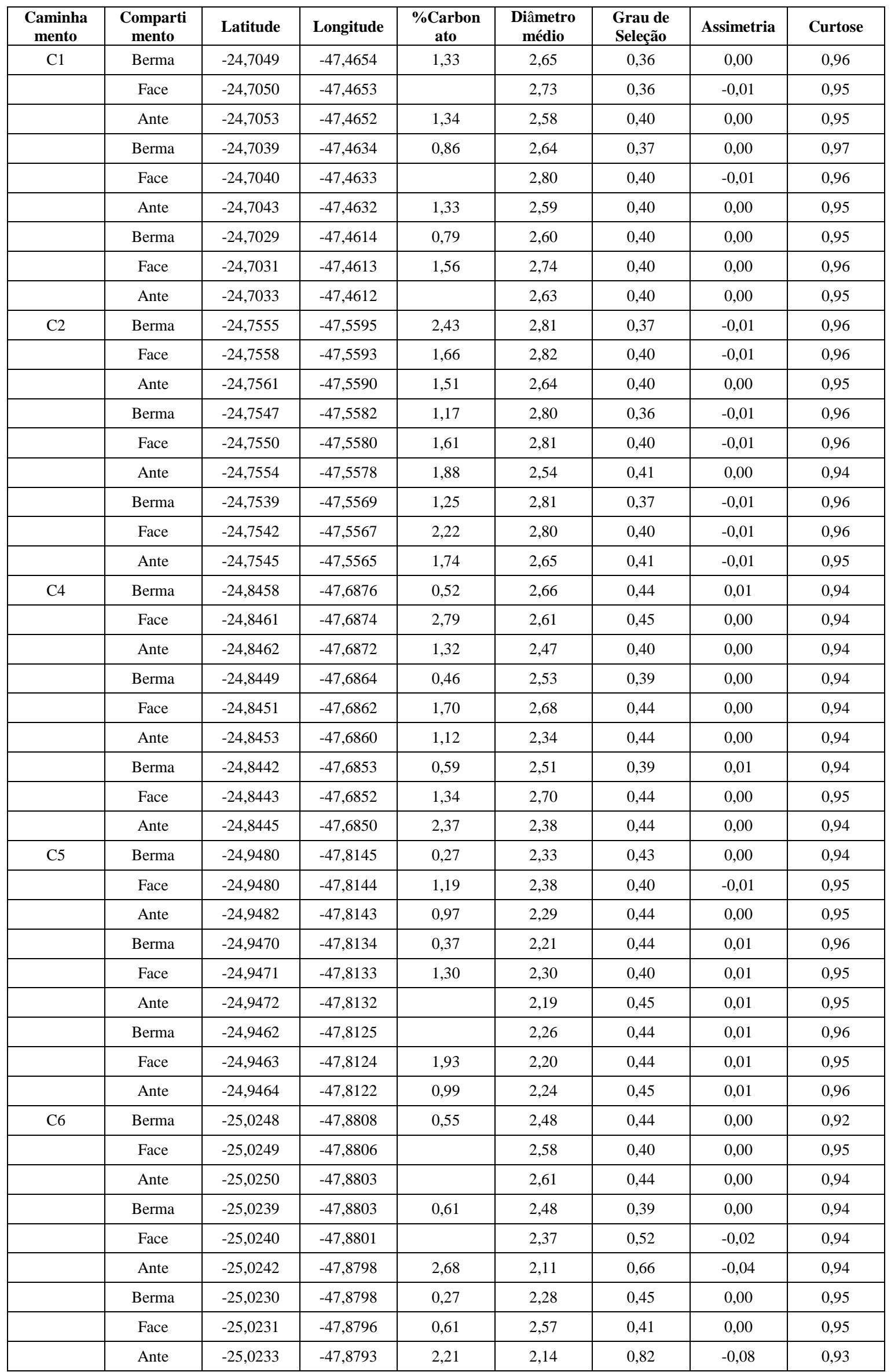


Tabela 8.2: Dados granulométricos referentes ao período B. As posições espaciais são aproximadas.

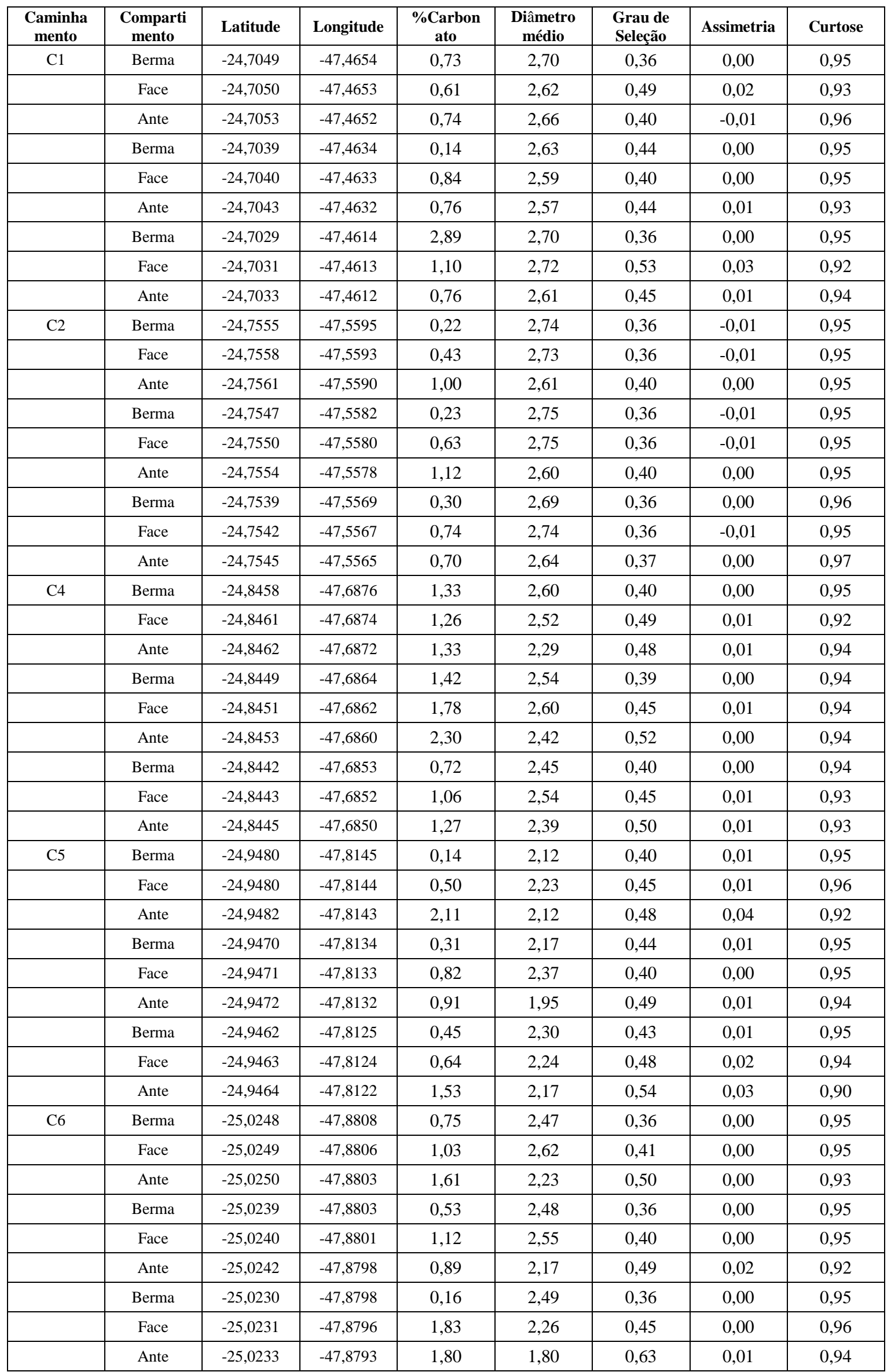


Tabela 8.3: Dados granulométricos referentes ao período C. As posições espaciais são aproximadas.

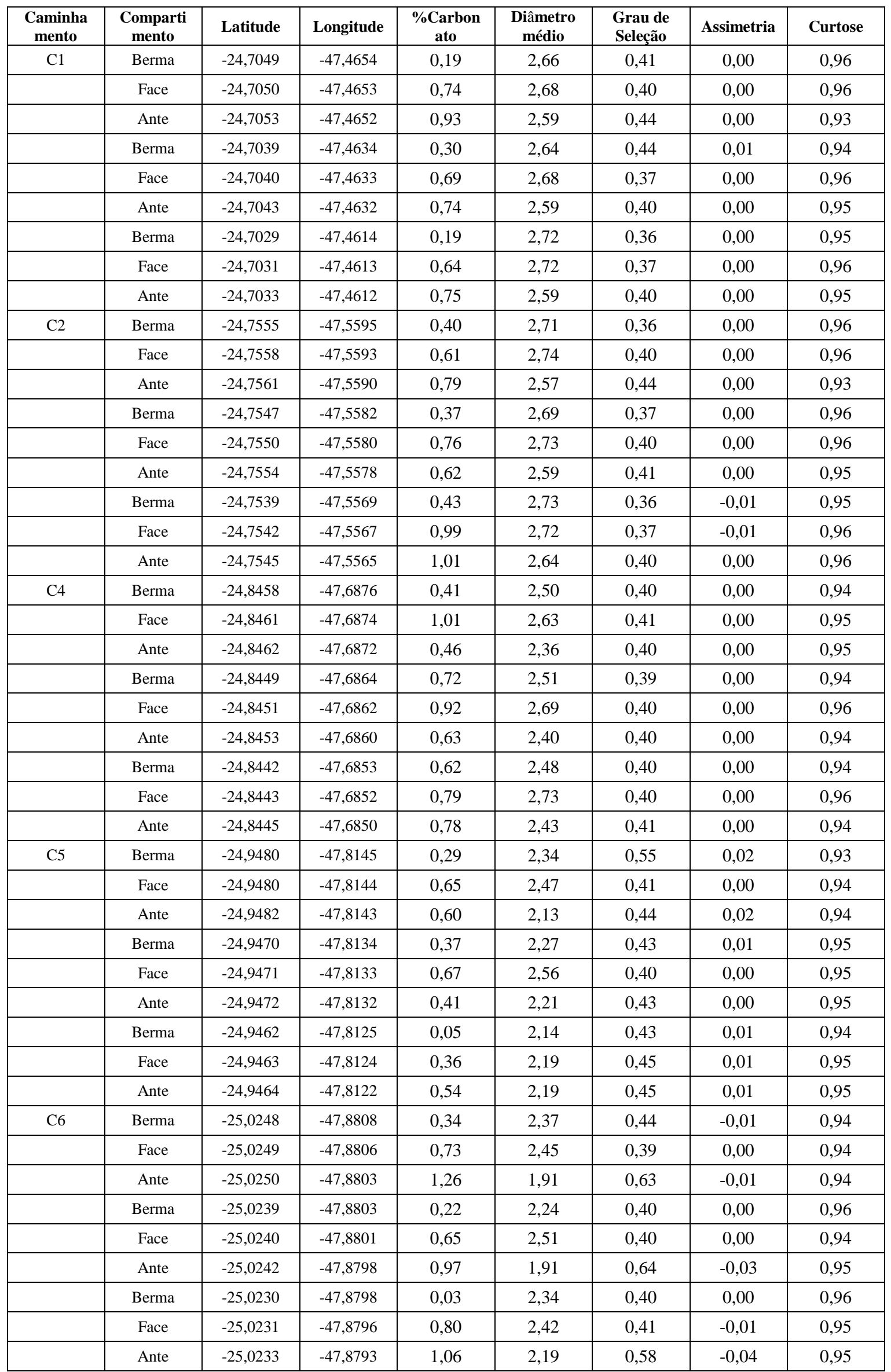


Tabela 8.4: Dados granulométricos referentes ao período D. As posições espaciais são aproximadas.

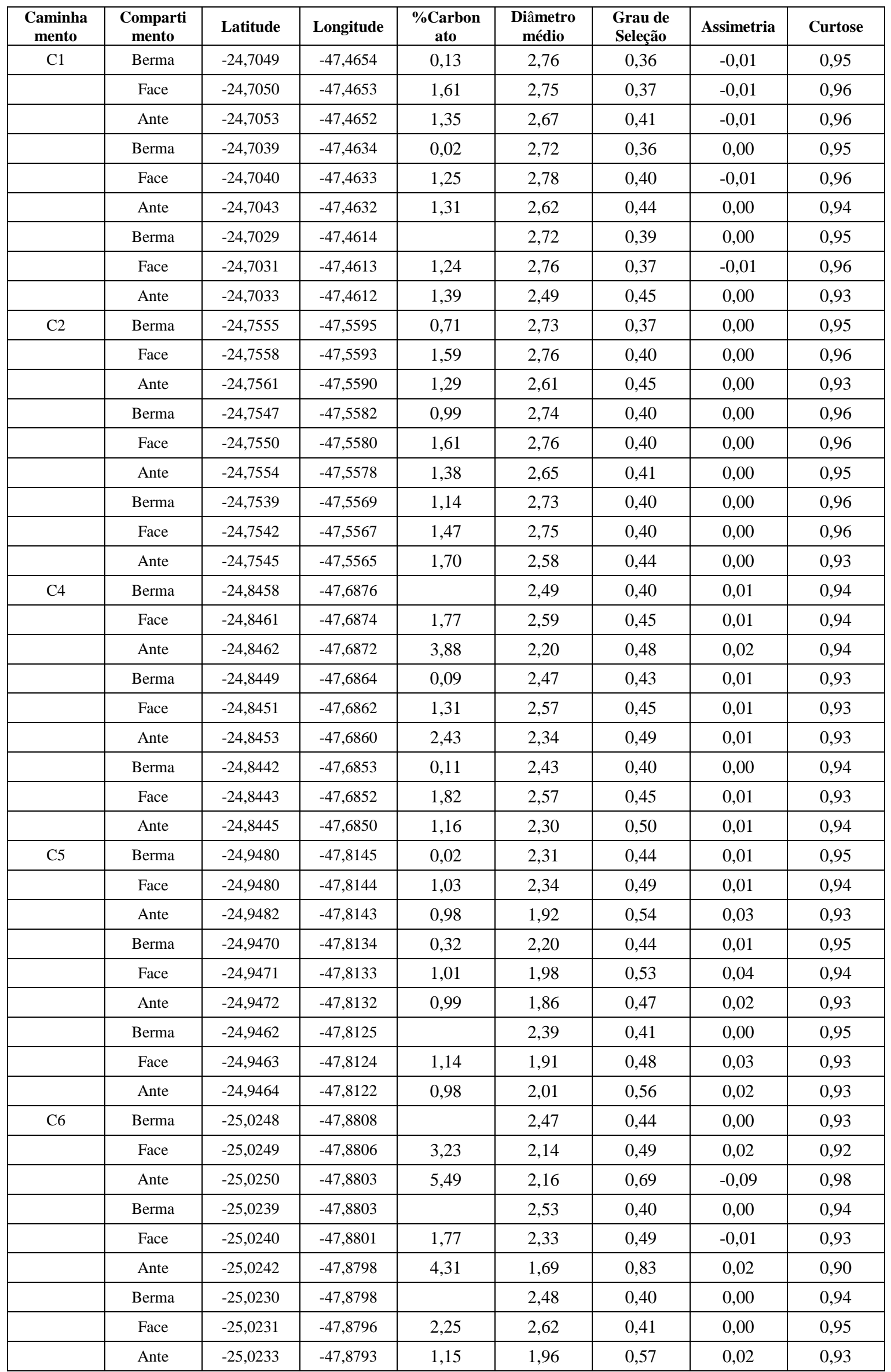


Tabela 8.5: Dados granulométricos referentes ao período E. As posições espaciais são aproximadas.

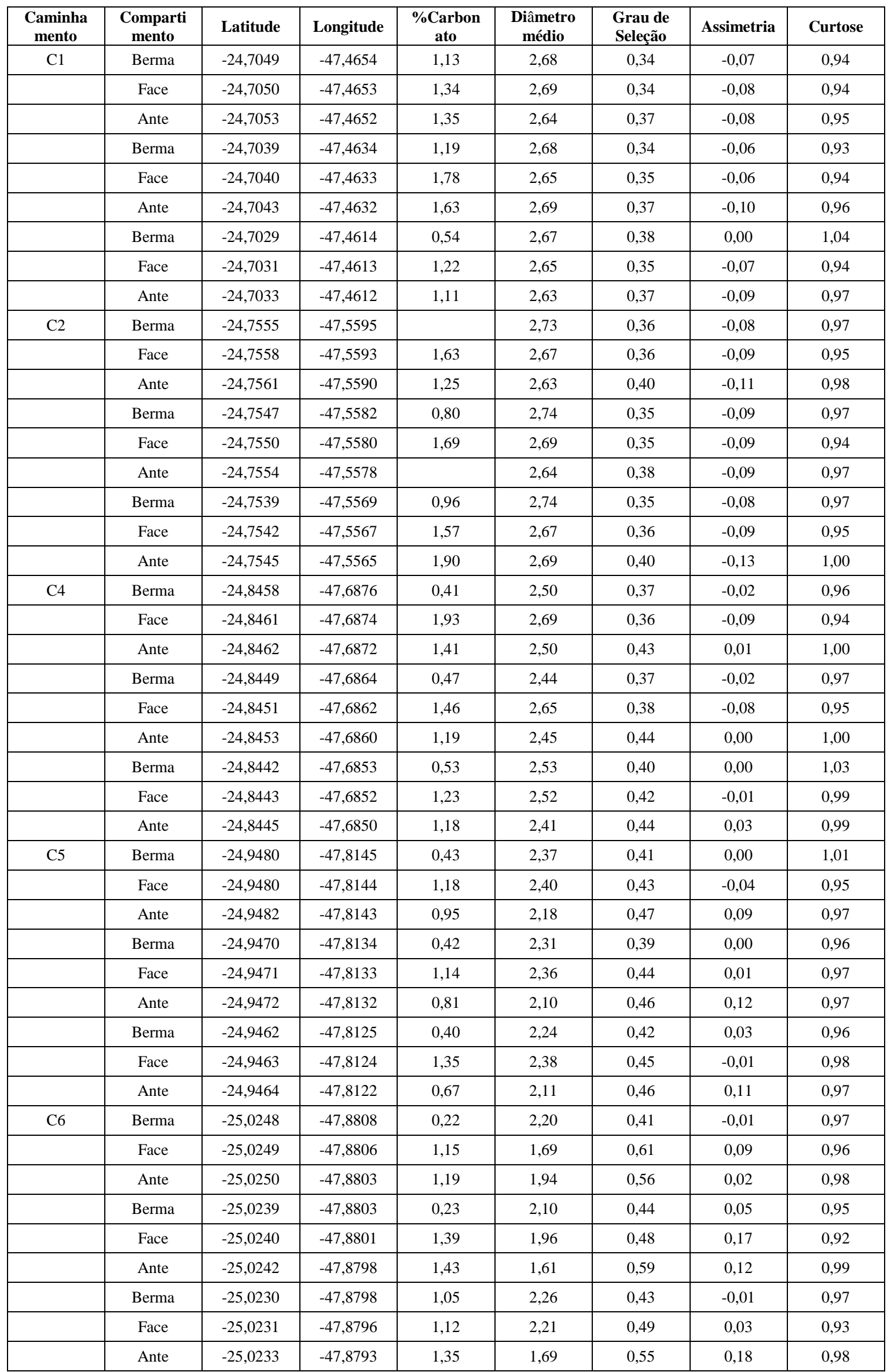


ANEXO II - MAPAS DE VARIAÇÃO ALTIMÉTRICA 


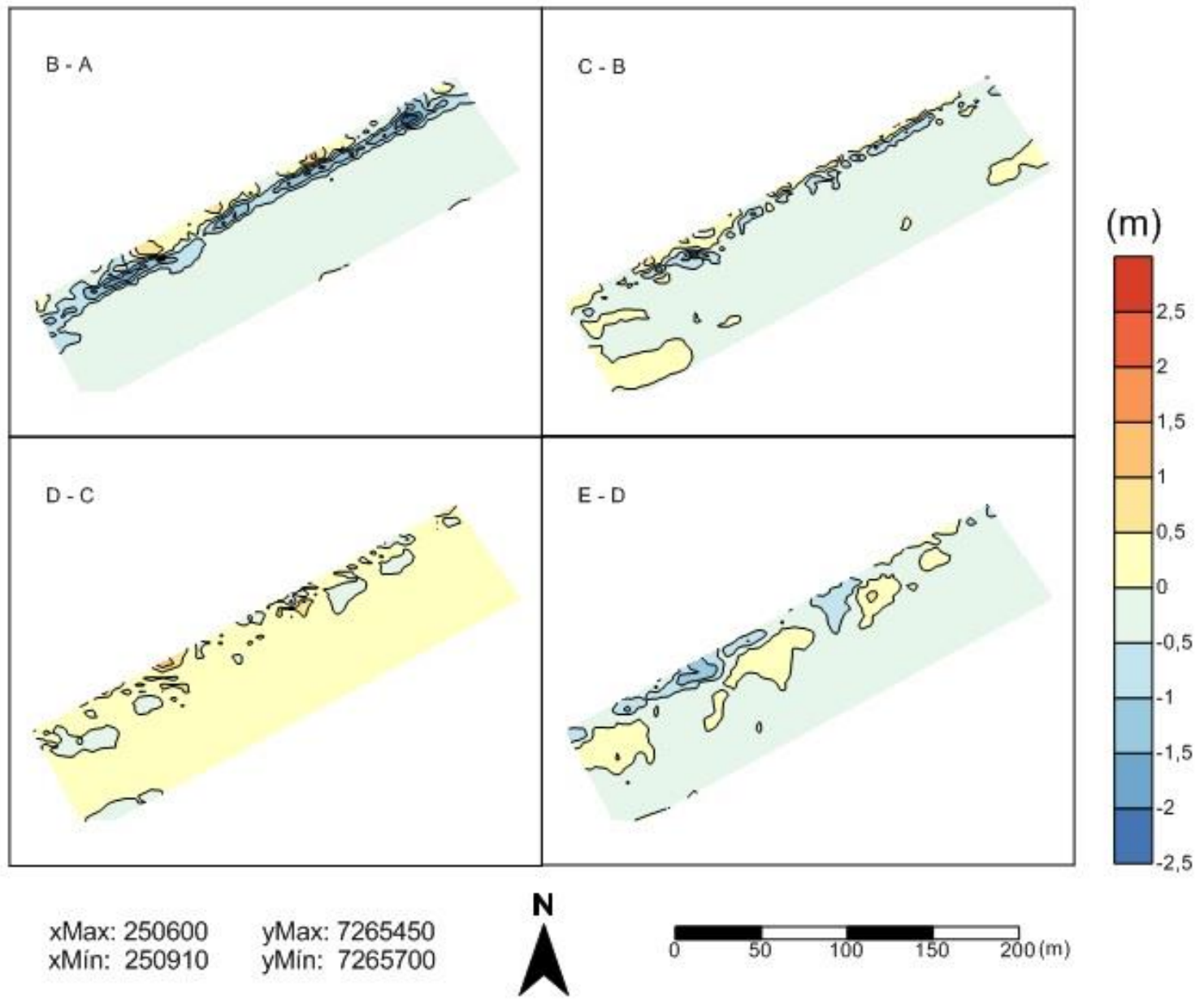

Figura 8.1: Mapas de variação altimétrica referentes ao Caminhamento 1. As letras indicam os períodos utilizados para o cálculo (final - inicial). 


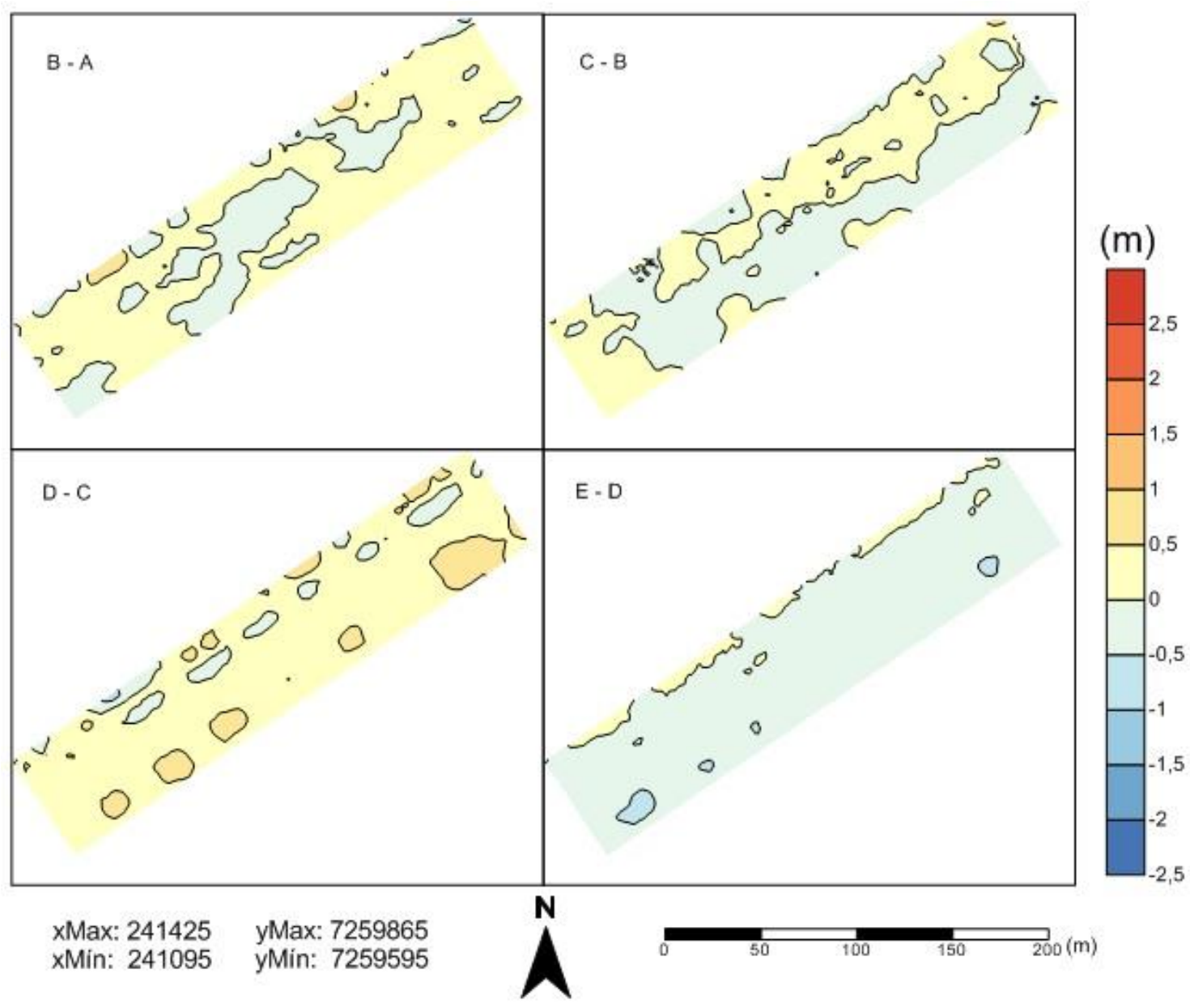

Figura 8.2: Mapas de variação altimétrica referentes ao Caminhamento 2. As letras indicam os períodos utilizados para o cálculo (final - inicial). 


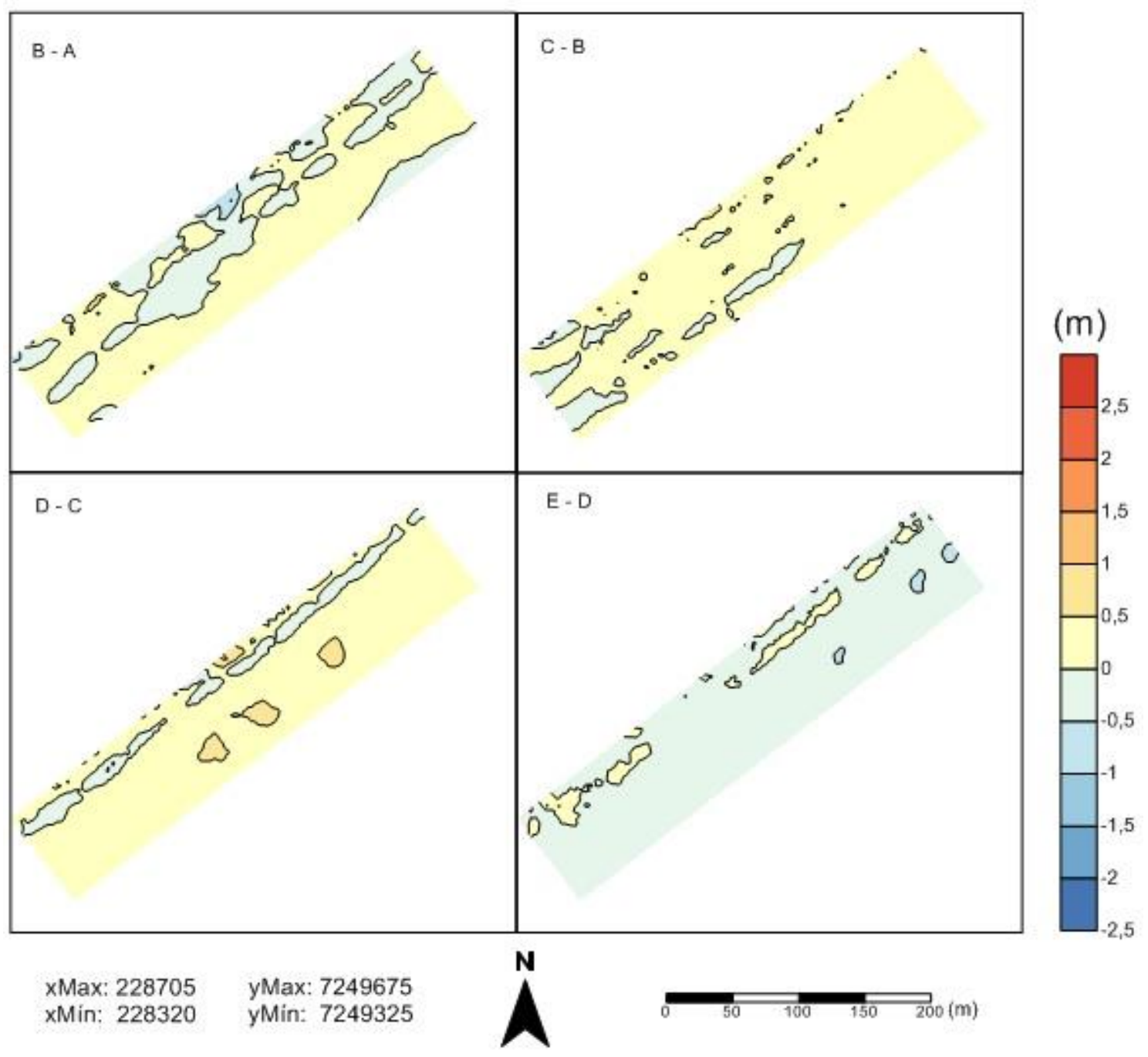

Figura 8.3: Mapas de variação altimétrica referentes ao Caminhamento 4. As letras indicam os períodos utilizados para o cálculo (final - inicial). 


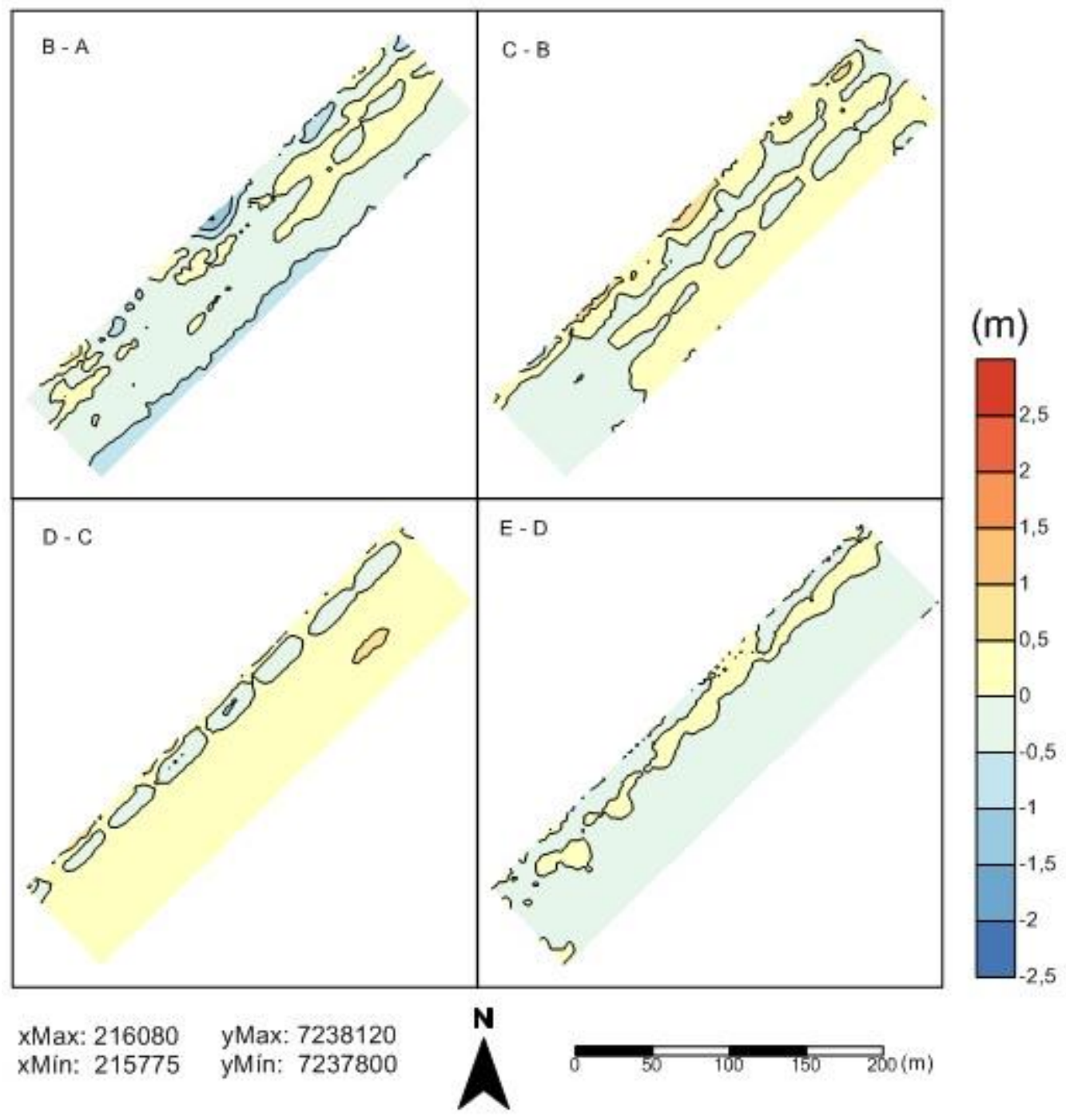

Figura 8.4: Mapas de variação altimétrica referentes ao Caminhamento 5. As letras indicam os períodos utilizados para o cálculo (final - inicial). 


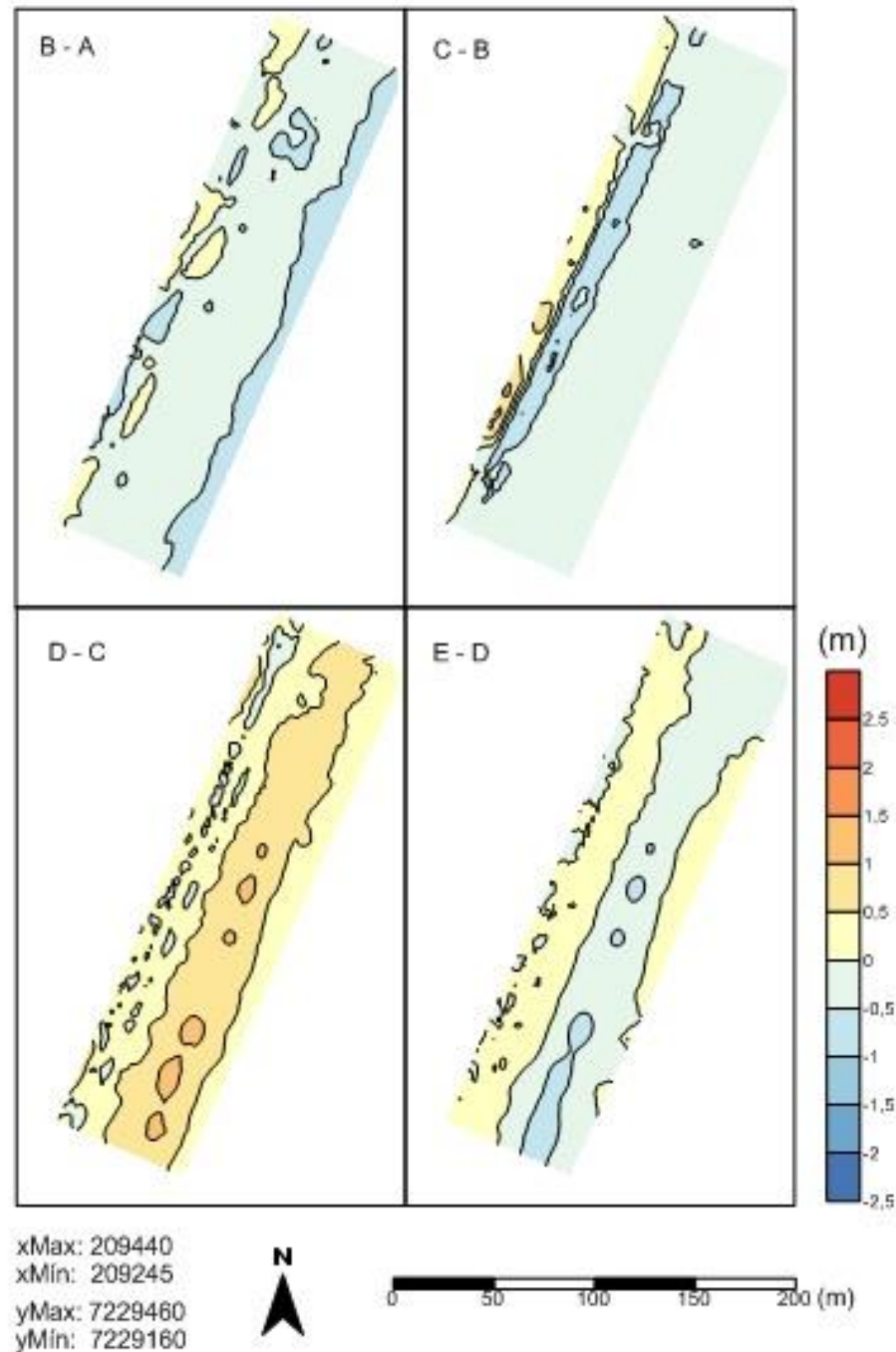

Figura 8.5: Mapas de variação altimétrica referentes ao Caminhamento 6. As letras indicam os períodos utilizados para o cálculo (final - inicial). 